(1)

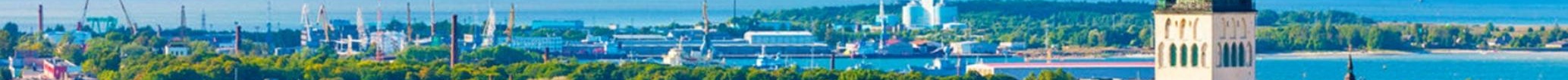

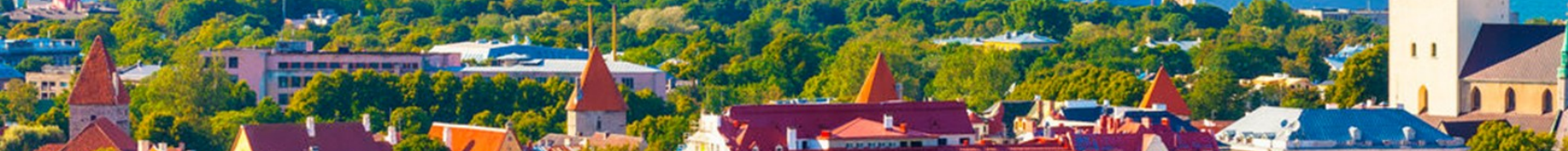

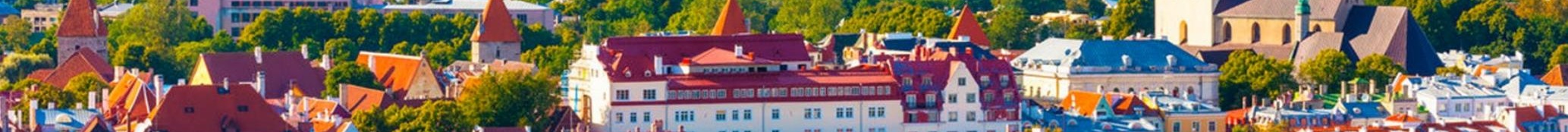
[4]

International Science Group

ISG-KONF.COM

\title{
XI
}

INTERNATIONAL SCIENTIFIC AND PRACTICAL

CONFERENCE "TOPICAL ISSUES OF MODERN SCIENCE AND EDUCATION ${ }^{\prime \prime}$

\section{Tallinn, Estonia}

March 11-13

ISBN 978-1-63732-132-4

DOI 10.46299/ISG.2021.I.XI 


\section{TOPICAL ISSUES OF MODERN SCIENCE AND EDUCATION}

Abstracts of XI International Scientific and Practical Conference

Tallinn, Estonia

March $11-13,2021$ 


\section{Library of Congress Cataloging-in-Publication Data}

UDC 01.1

The XI International Science Conference «Topical issues of modern science and education», March 11 - 13, 2021, Tallinn, Estonia. 248 p.

ISBN - 978-1-63732-132-4
DOI - 10.46299/ISG.2021.I.XI

EDITORIAL BOARD

\begin{tabular}{|c|c|}
\hline Pluzhnik Elena & $\begin{array}{l}\text { Professor of the Department of Criminal Law and Criminology } \\
\text { Odessa State University of Internal Affairs Candidate of Law, } \\
\text { Associate Professor }\end{array}$ \\
\hline Liubchych Anna & $\begin{array}{l}\text { Scientific and Research Institute of Providing Legal Framework for } \\
\text { the Innovative Development National Academy of Law Sciences of } \\
\text { Ukraine, Kharkiv, Ukraine, Scientific secretary of Institute }\end{array}$ \\
\hline Liudmyla Polyvana & $\begin{array}{l}\text { Department of Accounting and Auditing Kharkiv } \\
\text { National Technical University of Agriculture named after Petr } \\
\text { Vasilenko, Ukraine }\end{array}$ \\
\hline$\underline{\text { Mushenyk Iryna }}$ & $\begin{array}{l}\text { Candidate of Economic Sciences, Associate Professor of } \\
\text { Mathematical Disciplines, Informatics and Modeling. Podolsk State } \\
\text { Agrarian Technical University }\end{array}$ \\
\hline Oleksandra Kovalevska & $\begin{array}{l}\text { Dnipropetrovsk State University of Internal Affairs } \\
\text { Dnipro, Ukraine }\end{array}$ \\
\hline Prudka Liudmyla & $\begin{array}{l}\text { Odessa State University of Internal Affairs, } \\
\text { Associate Professor of Criminology and Psychology Department }\end{array}$ \\
\hline$\underline{\text { Slabkyi Hennadii }}$ & $\begin{array}{l}\text { Doctor of Medical Sciences, Head of the Department of Health } \\
\text { Sciences, Uzhhorod National University. }\end{array}$ \\
\hline Marchenko Dmytro & $\begin{array}{l}\text { Ph.D. in Machine Friction and Wear (Tribology), Associate } \\
\text { Professor of Department of Tractors and Agricultural Machines, } \\
\text { Maintenance and Servicing, Lecturer, Deputy dean on academic } \\
\text { affairs of Engineering and Energy Faculty of Mykolayiv National } \\
\text { Agrarian University (MNAU), Mykolayiv, Ukraine }\end{array}$ \\
\hline Harchenko Roman & $\begin{array}{l}\text { Candidate of Technical Sciences, specialty } 05.22 .20 \text { - } \\
\text { operation and repair of vehicles. }\end{array}$ \\
\hline Belei Svitlana & $\begin{array}{l}\text { Ph.D. (Economics), specialty: } 08.00 .04 \text { "Economics and } \\
\text { management of enterprises (by type of economic activity)" }\end{array}$ \\
\hline
\end{tabular}


TABLE OF CONTENTS

\begin{tabular}{|c|c|c|}
\hline \multicolumn{3}{|c|}{ AGRICULTURAL SCIENCES } \\
\hline 1. & $\begin{array}{l}\text { Hrynevych N., Zharchynska V. } \\
\text { POLYMERASE CHAIN REACTION AND ITS APPLICATION IN } \\
\text { AQUACULTURE }\end{array}$ & 10 \\
\hline 2. & $\begin{array}{l}\text { Господаренко Г.М., Любич В.В., Калантир В.В. } \\
\text { УДОБРЕННЯ ПШЕНИЦІ ТВЕРДОЇ ОЗИМОЇ }\end{array}$ & 12 \\
\hline 3. & $\begin{array}{l}\text { Станкевич С.В. } \\
\text { ПАСМО ЛЬОНУ (MYCOSPHAERELLA LINICOLA NAUMOV) } \\
\text { В УКРАЇНI }\end{array}$ & 16 \\
\hline \multicolumn{3}{|c|}{ ARCHITECTURE, CONSTRUCTION } \\
\hline 4. & $\begin{array}{l}\text { Солнцев А.Г., Усачова О.Ю., Богданова Л.О. } \\
\text { НЕГАТИВНИЙ ВПЛИВ ТА РОЗВИТОК ТРАНСПОРТУ В } \\
\text { ФОРМУВАННІ АРХІТЕКТУРНО-ПРОСТОРОВОЇ СТРУКТУРИ } \\
\text { МІСТА }\end{array}$ & 20 \\
\hline \multicolumn{3}{|c|}{ ART HISTORY } \\
\hline 5. & $\begin{array}{l}\text { Koniukhov S. } \\
\text { THE PECULIARITIES OF SUCCESSFUL CAPITALIZATION } \\
\text { AND MUSEUM SPACE REVIVAL }\end{array}$ & 23 \\
\hline \multicolumn{3}{|c|}{ BIOLOGICAL SCIENCES } \\
\hline 6. & $\begin{array}{l}\text { Курбатова І.М., Захаренко М.О., Чепіль Л.В. } \\
\text { ЕКОЛОГІЧНА ОЦІНКА ПРИ БІОІНДИКАЦЇ̈ ВОДОЙМ }\end{array}$ & 26 \\
\hline \multicolumn{3}{|c|}{ ECONOMIC SCIENCES } \\
\hline 7. & $\begin{array}{l}\text { Yanyshyn Y., Markiv G. } \\
\text { THE NEED FOR A TERRITORIAL ORGANIZATION OF } \\
\text { DIGITAL BANKING }\end{array}$ & 29 \\
\hline 8. & $\begin{array}{l}\text { Борисова В.А., Поцелуєва Т.С. } \\
\text { ФОРМУВАННЯ ОПТИМАЛЬНОГО ЗАЛИШКУ ГРОШОВИХ } \\
\text { КОШТІВ СІЛЬСЬКОГОСПОДАРСЬКИХ ПІДПРИСМСТВ }\end{array}$ & 32 \\
\hline
\end{tabular}




\begin{tabular}{|c|c|c|}
\hline 9. & $\begin{array}{l}\text { Борисова В.А., Козленко В.Р. } \\
\text { СИСТЕМА УПРАВЛІННЯ ЛОГІСТИЧНИМИ РИЗИКАМИ } \\
\text { ПІДПРИЄМСТВА }\end{array}$ & 34 \\
\hline 10. & $\begin{array}{l}\text { БілаНИч Л.В. } \\
\text { СУЧАСНІ ТЕНДЕНЦЇ У ПРОЦЕСІ ПРОФЕСІЙНОЇ } \\
\text { ПІДГОТОВКИ МАЙБУТНІХ ФАХІВЦІВ ЕКОНОМІЧНОГО } \\
\text { ПРОФІЛЮ }\end{array}$ & 36 \\
\hline 11. & $\begin{array}{l}\text { Геєнко М.М., ЗаваЛЬний М.В. } \\
\text { РОЗРОБКА СТРАТЕГІЧНИХ НАПРЯМКІВ РОЗВИТКУ } \\
\text { ВЗАЄМОВІДНОСИН В СИСТЕМІ «ВЛАДА-БІЗНЕС- } \\
\text { ГРОМАДА» }\end{array}$ & 41 \\
\hline 12. & $\begin{array}{l}\text { Трушкіна Н.В. } \\
\text { АКТУАЛЬНІ ПРОБЛЕМИ ФУНКЦІОНУВАННЯ } \\
\text { ТРАНСПОРТНОЇ ІНФРАСТРУКТУРИ В ЕСТОНІЇ }\end{array}$ & 43 \\
\hline \multicolumn{3}{|c|}{ GEOGRAPHICAL SCIENCE } \\
\hline 13. & $\begin{array}{l}\text { Лабінська Г.М. } \\
\text { АДАПТАЦІЯ ПРОСТОРУ У КРАЇНАХ ЄВРОПИ У КОНТЕКСТІ } \\
\text { ВИКЛИКІВ ПАНДЕМІЇ СОVID-19 }\end{array}$ & 48 \\
\hline \multicolumn{3}{|c|}{ HISTORICAL SCIENCES } \\
\hline 14. & $\begin{array}{l}\text { Автушенко І.Б., Автушенко О.С. } \\
\text { УТВЕРДЖЕННЯ ПОЛІТИЧНОЇ ЕТИКИ ЛІВОГО } \\
\text { РАДИКАЛІЗМУ В КУЛЬТУРНЙ ТВОРЧОСТІ }\end{array}$ & 54 \\
\hline 15. & $\begin{array}{l}\text { Нікітенко К.В. } \\
\text { ДО ПИТАННЯ ПРО МЕТОДИ, ОСОБЛИВОСТІ } \\
\text { ФІНАНСУВАННЯ І НАСЛІДКИ РАДЯНСЬКОЇ } \\
\text { ІНДУСТРІАЛІЗАЦЇ̈ }\end{array}$ & 59 \\
\hline \multicolumn{3}{|c|}{ LEGAL SCIENCES } \\
\hline 16. & $\begin{array}{l}\text { Козирєва В.П., МеЛЬНИченКо І.С. } \\
\text { ПРОВАДЖЕННЯ У СПРАВАХ ПРО ОСКАРЖЕННЯ РІШЕНЬ } \\
\text { ТРЕТЕЙСЬКИХ СУДІВ }\end{array}$ & 65 \\
\hline 17. & $\begin{array}{l}\text { Миткаленна А.Ю., Хатнюк Н.С. } \\
\text { ПРАВОВЕ РЕГУЛЮВАННЯ ВІДНОСИН IНТЕРНЕТ- } \\
\text { ТРЕЙДИНГУ ДОСВІД РЕГУЛЮВАННЯ РИНКУ FORЕХ }\end{array}$ & 70 \\
\hline
\end{tabular}




\begin{tabular}{|c|c|c|}
\hline 18. & $\begin{array}{l}\text { Савліва Н.О. } \\
\text { ДОВЕДЕННЯ ДО САМОГУБСТВА: ПРОБЛЕМИ } \\
\text { КРИМІНАЛЬНО-ПРАВОВОГО РЕГУЛЮВАННЯ }\end{array}$ & 74 \\
\hline 19. & $\begin{array}{l}\text { Судак І.М., Попова Д.А. } \\
\text { ПЕРЕХІД ТРУДОВОГО ДОГОВОРУ В ЦИФРОВУ ПЛОЩИНУ }\end{array}$ & 76 \\
\hline \multicolumn{3}{|c|}{ MANAGEMENT, MARKETING } \\
\hline 20. & $\begin{array}{l}\text { Senyshyn O. } \\
\text { SCIENTIFIC APPROACHES TO UNDERSTANDING OF } \\
\text { PRODUCT COMPETITIVENESS MANAGEMENT SYSTEM }\end{array}$ & 78 \\
\hline \multicolumn{3}{|c|}{ MEDICAL SCIENCES } \\
\hline 21. & $\begin{array}{l}\text { Barannyk S., Barannik C., Shevtsov V. } \\
\text { PROBLEME DER DIAGNOSE, BEHANDLUNG UND } \\
\text { PRÄVENTION URINÄRE DIATHESE }\end{array}$ & 83 \\
\hline 22. & $\begin{array}{l}\text { Posternak H., Krivoruchko M., Posternak D. } \\
\text { BIOCHEMICAL MARKERS OF THE SERIOUSNESS OF } \\
\text { HYPOXIC-ISCHEMIC CNS DAMAGE IN NEWBORN }\end{array}$ & 87 \\
\hline 23. & $\begin{array}{l}\text { Shylava M., Dotsenko M., Valchuk I. } \\
\text { AGE STRUCTURE OF HIV INFECTED PEOPLE MORTALITY IN } \\
\text { MINSK }\end{array}$ & 89 \\
\hline 24. & $\begin{array}{l}\text { Бєліков О.Б., Сорохан М.М., БєЛікова Н.І. } \\
\text { ДЕЯКІ ФІЗИКО-МЕХАНІЧНІ ВЛАСТИВОСТІ } \\
\text { САМОАДГЕЗИВНОГО І САМОПРОТРАВЛЮЮЧОГО } \\
\text { КОМПОЗИТУ ПОДВІЙНОЇ ФІКСАЦІЇ «МАХСЕМ ЕLІТЕТМ» } \\
\text { ЯК ФІКСУВАЛЬНОГО МАТЕРІАЛУ ТА ЙОГО АНАЛОГІВ }\end{array}$ & 93 \\
\hline 25. & $\begin{array}{l}\text { Козинець Г.П., Коваленко О.М., Циганков В.П. } \\
\text { ВИБІР ТАКТИКИ ЛІКУВАННЯ ОПІКІВ В ОСІБ ПОХИЛОГО } \\
\text { ТА СТАРЕЧОГО ВІКУ }\end{array}$ & 97 \\
\hline 26. & $\begin{array}{l}\text { Трофимченко Т.С. } \\
\text { ПАРАМЕТРИЧНЕ ОЦННЮВАННЯ ТЯЖКОСТІ СТАНУ І } \\
\text { ПРОГНОЗУВАННЯ НАСЛІДКІВ ПОШКОДЖЕНЬ ПРИ } \\
\text { ПОЛІТРАВМІ }\end{array}$ & 100 \\
\hline
\end{tabular}


PEDAGOGICAL SCIENCES

\begin{tabular}{|c|c|c|}
\hline 27. & $\begin{array}{l}\text { Mishchenko O., Bezdetko N. } \\
\text { MODERN TECHNOLOGIES AND OPPORTUNITIES FOR } \\
\text { INCREASING THE PROFESSIONAL LEVEL OF PHARMACY } \\
\text { SPECIALISTS DURING THE COVID-19 PANDEMIC }\end{array}$ & 105 \\
\hline 28. & $\begin{array}{l}\text { Nozdrova O., Bartienieva I. } \\
\text { FORMATION OF CREATIVE POTENTIAL OF THE FUTURE } \\
\text { TEACHER DURING THE INTERNSHIP IN CHILDREN'S } \\
\text { SUMMER HEALTH CAMPS }\end{array}$ & 107 \\
\hline 29. & $\begin{array}{l}\text { Soluianova G. } \\
\text { CREATIVITY AT SCHOOL }\end{array}$ & 111 \\
\hline 30. & $\begin{array}{l}\text { АсмансьКа Л.К. } \\
\text { ВИКОРИСТАННЯ СЕРВІСІВ ПРИ ДИСТАНЦІЙНОМУ } \\
\text { НАВЧАННІ ГЕОГРАФІЇ }\end{array}$ & 114 \\
\hline 31. & $\begin{array}{l}\text { Бойко Р.М. } \\
\text { ВИКОРИСТАННЯ СЕРВІСІВ WЕВ } 2.0 \text { В ОСВІТНІЙ } \\
\text { ДІЯЛЬНОСТІ } 3 \text { МЕТОЮ СОЦІАЛІЗАЦІЇ УЧНІВ }\end{array}$ & 118 \\
\hline 32. & $\begin{array}{l}\text { Галан О.М., Курчаба О.С. } \\
\text { ВИКОРИСТАННЯ ДЕБАТІВ У ВИКЛАДАННІ СУСПІЛЬНИХ } \\
\text { ДИСЦИПЛІН }\end{array}$ & 122 \\
\hline 33. & $\begin{array}{l}\text { ГаращеНКО Л.В. } \\
\text { СТВОРЕННЯ ЗДОРОВ’ЯЗБЕРЕЖУВАЛЬНОГО СЕРЕДОВИЩА } \\
\text { В ЗАКЛАДАХ ДОШКІЛЬНОЇ ОСВІТИ: МЕТОДИЧНЕ } \\
\text { ВИРАЖЕННЯ }\end{array}$ & 125 \\
\hline 34. & $\begin{array}{l}\text { Горбатюк Р.М., Білан Н.М. } \\
\text { ПРОЄКТНА РОБОТА ЯК ФОРМА ОРГАНІЗАЦЇ̈ } \\
\text { ІНШОМОВНОЇ ПІДГОТОВКИ МАЙБУТНІХ ІНЖЕНЕРІВ- } \\
\text { ЕНЕРГЕТИКІВ }\end{array}$ & 129 \\
\hline 35. & $\begin{array}{l}\text { Дядиченко Е.А. } \\
\text { ЦИФРОВЫЕ ТЕХНОЛОГИИ ДЛЯ ПОВЫШЕНИЯ КАЧЕСТВА } \\
\text { ОБРАЗОВАНИЯ }\end{array}$ & 132 \\
\hline
\end{tabular}




\begin{tabular}{|c|c|c|}
\hline 36. & $\begin{array}{l}\text { Карпич І.О. } \\
\text { СОЦІАЛЬНА РОБОТА } 3 \text { ПРОФІЛАКТИКИ НЕГАТИВНИХ } \\
\text { ЯВИЩ У МОЛОДІЖНОМУ СЕРЕДОВИЩІ }\end{array}$ & 136 \\
\hline 37. & $\begin{array}{l}\text { Моргай Л.А. } \\
\text { ЗНАЧЕННЯ СОЦІАЛЬНОГО ПАКЕТА НА ПІДПРИСМСТВІ }\end{array}$ & 139 \\
\hline 38. & $\begin{array}{l}\text { Передерій О.Л. } \\
\text { ОСОБЛИВОСТІ РОЗВИТКУ ЕМОЦІЙНОГО ІНТЕЛЕКТУ } \\
\text { ДІТЕЙ ДОШКІЛЬНОГО ВІКУ }\end{array}$ & 142 \\
\hline 39. & $\begin{array}{l}\text { Поліщук В.В., Гордієнко О.І., Волківський М.В. } \\
\text { ОРГАНІЗАЦІЯ ФІЗИЧНОї КУЛЬТУРИ УЧНІВ В } \\
\text { ПОЗАКЛАСНІЙ ДІЯЛЬНОСТІ ЗАГАЛЬНООСВІТНЬОЇ } \\
\text { ШКОЛИ }\end{array}$ & 145 \\
\hline 40. & $\begin{array}{l}\text { СУХорська Н.I. } \\
\text { ВИКЛИКИ СУЧАСНІЙ СИСТЕМІ ОСВІТИ В УМОВАХ } \\
\text { ВСЕСВІТНЬОЇ ПАНДЕМІЇ СОVID 19. ЗАЛУЧЕННЯ ІНТЕРНЕТ } \\
\text { РЕСУРСІВ ТА ІНШІ АСПЕКТИ ДИСТАНЦЙНОГО ТА } \\
\text { ЗМІШАНОГО ВИКЛАДАННЯ ІНОЗЕМНӦ̈ (ІСПАНСЬКОЇ) } \\
\text { МОВИ }\end{array}$ & 151 \\
\hline 41. & $\begin{array}{l}\text { Чалій Л., Мамчур С., БУтенко Т. } \\
\text { ОБГРУНТУВАННЯ МЕТОДІВ, ВИКОРИСТАНИХ У } \\
\text { ПІДГОТОВЦІ МАЙБУТНІХ УЧИТЕЛІВ ФІЗИЧНОЇ КУЛЬТУРИ } \\
\text { ДО ОРГАНІЗАЦЇ ПОЗАКЛАСНОЇ РОБОТИ З ТУРИЗМУ }\end{array}$ & 154 \\
\hline 42. & $\begin{array}{l}\text { Шашкенова А.Ж., Жолмаганбетова Д.К., Дахбай Б.Д. } \\
\text { ЖАһАНДАНУ КОНТЕКСІНДЕГІ ИНКЛЮЗИВТІ БІЛІМ БЕРУ }\end{array}$ & 158 \\
\hline 43. & $\begin{array}{l}\text { Шепітько В.І., Борута Н.В., СТецУк Є.В. } \\
\text { ДИСТАНЦІЙНА ОСВІТА НАУКОВО-ПЕДАГОГІЧНИХ } \\
\text { ПРАЦІВНИКІВ ЗАБЕЗПЕЧУС ІННОВАЦЙНІ } \\
\text { НОВОВВЕДЕННЯ В СИСТЕМІ ОСВІТИ }\end{array}$ & 164 \\
\hline 44. & $\begin{array}{l}\text { ШУМило М.Ю. } \\
\text { ПІДГОТОВКА ЛІКАРІВ-ІНТЕРНІВ В УМОВАХ } \\
\text { РЕФОРМУВАННЯ СИСТЕМИ ОХОРОНИ ЗДОРОВ'Я } \\
\text { УКРАЇНИ }\end{array}$ & 167 \\
\hline
\end{tabular}




\begin{tabular}{|c|c|c|}
\hline 45. & $\begin{array}{l}\text { Ярошенко О.М. } \\
\text { МУЗИЧНА ДРАМАТУРГІЯ ЯК ЧИННИК ДИНАМІЧНОГО } \\
\text { РОЗВИТКУ МУЗИЧНОГО ТВОРУ }\end{array}$ & 170 \\
\hline \multicolumn{3}{|c|}{ PHARMACEUTICAL SCIENCES } \\
\hline 46. & $\begin{array}{l}\text { Козирєва О.В., Коляда Т.А., Сагайдак-Нікітюк Р.В. } \\
\text { ПРАВОВЕ РЕГУЛЮВАННЯ ОСВІТНЬОЇ ДІЯЛЬНОСТІ У } \\
\text { ФАРМАЦІї }\end{array}$ & 174 \\
\hline \multicolumn{3}{|c|}{ PHILOLOGICAL SCIENCES } \\
\hline 47. & $\begin{array}{l}\text { Zahorodnia O., Korobova I. } \\
\text { BLENDED LEARNING AT HIGHER EDUCATIONAL } \\
\text { ESTABLISHMENTS: ADVANTAGES AND DISADVANTAGES }\end{array}$ & 181 \\
\hline 48. & $\begin{array}{l}\text { Білик Я.С., Лісовий М.І. } \\
\text { СТОРІНКА } 3 \text { ЖИТТЯ ЕЖЕНА СЮ }\end{array}$ & 185 \\
\hline 49. & $\begin{array}{l}\text { Киселевич І.В. } \\
\text { ФОРМУВАННЯ МОВИ ФАХІВЦЯ ЗА ДОПОМОГОЮ } \\
\text { КОМБІНАТОРНОГО СЛОВНИКА }\end{array}$ & 189 \\
\hline 50. & $\begin{array}{l}\text { Краснопеева А.А. } \\
\text { ПОЭТИКА НОВОГОДНИХ РАССКАЗОВ А. П. ЧЕХОВА }\end{array}$ & 192 \\
\hline 51. & $\begin{array}{l}\text { Матвіяс О., Базиляк Н., БУдЗин В. } \\
\text { ТЕРМІНОЛОГІЗАЦІЯ ЗАГАЛЬНОВЖИВАНОЇ ЛЕКСИКИ (НА } \\
\text { ПРИКЛАДІ ТЕРМІНОСИСТЕМИ ГАЛУЗІ ТУРИЗМУ) }\end{array}$ & 196 \\
\hline \multicolumn{3}{|c|}{ PHYSICAL AND MATHEMATICAL SCIENCES } \\
\hline 52. & $\begin{array}{l}\text { Колодяжний В.М., Плєхова Г.А., Кочуєва 3.А. } \\
\text { СТВОРЕННЯ МОБІЛЬНОГО ДОДАТКУ В ТРАНСПОРТНИХ } \\
\text { СИСТЕМАХ }\end{array}$ & 200 \\
\hline 53. & $\begin{array}{l}\text { Купріянчук В.М., БУднИк М.М. } \\
\text { МЕТОД ФЛУОРЕСЦЕНТНОЇ ВІЗУАЛІЗАЦІЇ } \\
\text { НАНОЧАСТИНОК В ТІЛІ ЛАБОРАТОРНИХ ТВАРИН } \\
\text { (ОГЛЯД) }\end{array}$ & 202 \\
\hline
\end{tabular}


POLITICAL SCIENCE

54. Shubitidze V., Davitashvili O.

PANDEMIC POLITICAL SCIENCE AND CORONAPOLITICS

\section{PSYCHOLOGICAL SCIENCES}

55. Bocheliuk V., Gaivoronska T.

BASICS OF PSYCHODIAGNOSTIC TOOLS FOR STUDYING FEATURES OF SELF-ACTUALIZATION OF PSYCHOLOGISTS IN THE PROCESS OF PROFESSIONAL TRAINING

56. Panov M., Netrebenko M.

PSYCHOLOGICAL CORRECTION OF AGGRESSIVENESS OF ADOLESCENTS WITH CHILDHOOD CEREBRAL PALSY

57. Пономарьова В.Л., Захарченко В.В.

РОЛЬ ІГРОВИХ ТЕХНОЛОГІЙ У ПРОФІЛАКТИКИ

НЕГАТИВНИХ ЕМОЦІЙНИХ СТАНІВ ДОШКІЛЬНЯТ

58. Примак Ю.В.

ДИНАМІКА ВЗАСМИН В БАТЬКІВСЬКО-ДИТЯЧІЙ

ПІДСИСТЕМІ ЯК ІНДИКАТОР ПСИХОЛОГІЧНОЇ БЕЗПЕКИ В CIM'Ï

\section{TECHNICAL SCIENCES}

59. Ж Жумабоева М.Б.К., Бояркина О.В.

ОСОБЕННОСТИ ЭКСПЛУАТАЦИИ КРУПНЫХ НЕФТЯНЫХ И ГАЗОВЫХ ПРОМЫСЛОВ УЗБЕКИСТАНА

60. Зинченко А.В., Хоменко А.Н., Федорова Н.В.

АНАЛИЗ “ИНТЕРНЕТ ВЕЩЕЙ” И СФЕРЫ ЕГО ПРИМЕНЕНИЯ

61. Москаленко А.О., Івко С.О., Погорілий В.С.

ЕЛЕКТРОННИЙ НАВЧАЛЬНО-МЕТОДИЧНИЙ КОМПЛЕКС ДИСЦИПЛІНИ «БАЗИ ДАНИХ»

62. Немченко О.В.

ЕКОЛОГІЧНА ОЦІНКА ПРОЦЕСУ СТИМУЛЯЦІІ

ГАЗОПЕРСПЕКТИВНОГО РОДОВИЩА

63. Сікуліна А.Ю., Сидоренко О.М.

ЯК ПІДВИЩИТИ ЕФЕКТИВНІСТЬ КОНТРОЛЮ І НАГЛЯДУ У СФЕРІ ОХОРОНИ АТМОСФЕРНОГО ПОВІТРЯ 


\title{
POLYMERASE CHAIN REACTION AND ITS APPLICATION IN AQUACULTURE
}

\author{
Hrynevych Nataliia, \\ Associate professor Departmet of Ichthyology and Zoology \\ Bila Tserkva National Agrarian University \\ Zharchynska Valeriia, \\ Assistant of the Department of Ichthyology and Zoology \\ Bila Tserkva National Agrarian University
}

Diseases of aquatic organisms cause significant economic damage to aquaculture. Monitoring the patterns of their occurrence and spread, the development of effective tools for diagnosis, prevention and treatment - a topical issue that reflects the effectiveness of reproduction and cultivation of aquatic organisms. Diagnostic methods of infectious diseases, characterized by continuous improvement with the search and testing of new, effective, including several express [4].

At present, the most widely used in aquaculture practice is polymerase chain reaction (PCR). It is characterized by high specificity, sensitivity, versatility and short research time. Polymerase chain reaction - a method of significantly increasing small concentrations of certain nucleic acid fragments (DNA) in biological material (sample) [1].

Using this method, you can isolate any gene from any organism. Due to the accuracy and speed, compared to many other diagnostic methods, PCR has become relevant in the diagnosis of aquatic diseases. Detection and identification of bacterial and viral pathogens are accelerated to 24 hours. If the infectious agent is difficult to identify by culture, the use of PCR is an alternative to confirm the presence of the pathogen in the pathological material $[1,2]$.

The method of real-time polymerase chain reaction (PCR-RT, Real-Time PCR) is now becoming increasingly common for the diagnosis of infectious diseases in aquaculture. Its main feature is a comprehensive analysis of the accumulation of polymerase chain reaction products, as well as automatic registration and interpretation of the results. This method does not require an electrophoresis step, which simplifies the requirements for PCR laboratories [3].

It should be noted that PCR-RT reflects the yield of the amplification product after each cycle. According to the obtained data, a kinetic PCR curve is created and then, based on the analysis of the obtained curve, the relative substrate concentration is calculated. The entire reaction process is scanned in real time on a computer monitor. To detect the PCR product, dyes are used that provide fluorescence directly 
proportional to the amount of PCR product (reporter fluorescence). The mechanisms of generation of reference fluorescence differ depending on the type of PCR-RT $[1,4]$.

There are two main approaches to real-time PCR detection: using intercalating dyes and fluorescently labeled oligonucleotide probes $[2,4]$.

We conducted an experimental study on the establishment of the third type of carp koi herpesvirus (CyHV-3) in the Rangia cuneata mollusk. Real-time polymerase chain reaction (PCR-RT) was performed on isolates of bivalve mollusk Rangia cuneata (or Atlantic rangia). The reaction mixture for PCR-RT contained: $\mathrm{MIX} \rightarrow \mathrm{H}_{2} \mathrm{O}-3.65 \mu \mathrm{l}$; Mix (Probe RT-Master Mix) - $5 \mu \mathrm{l} ; \mathrm{S}_{1}-0.15 \mu \mathrm{l} ; \mathrm{S}_{2}-0.15 \mu \mathrm{l}$; probe sample $-0.05 \mu \mathrm{l}$; DNA $-1 \mu \mathrm{l}$. Then $8 \mu \mathrm{l}$ of mix was added to each of the pre-prepared eppendorf tubes. Mixing was performed using a mini-centrifuge Combi-Spin FVL - 2400N (BioSan). After centrifugation, the test material was placed in an amplifier LightCycler ${ }^{\circledR} 480$ II (Roche). Treatment scheme in the amplifier: preincubation -1 cycle $-95^{\circ} \mathrm{C}-10 \mathrm{~min}$; amplification $-95^{\circ} \mathrm{C}-10 \mathrm{sec} ., 60^{\circ} \mathrm{C}-30 \mathrm{sec} .-45$ cycles; cooling $-40^{\circ} \mathrm{C}-10 \mathrm{sec}$. 1 cycle, followed by obtaining amplification schedules.

The following criteria were used to evaluate the amplification efficiency: the value of the angle of inclination of the kinetic curve (A), the amplification efficiency (E) and the value of the correlation coefficient $\mathrm{R} 2$. The results of the reaction were considered satisfactory, because the value of the angle of the curve is in the range from $-3.6 \leq \mathrm{A} \leq$ -3.1 , which corresponds to the amplification efficiency of $90-110 \%$, and the average value of the correlation coefficient $\mathrm{R} 2 \geq 0.98$.

The fluorescent signal was measured at the stage of hybridization and synthesis in each amplification cycle. The cut-off line and baseline fluorescence were calculated automatically upon completion of the reaction. Processing of the obtained results was carried out in accordance with the manufacturer's instructions of the device and software.

Thus, the absence of carp koi herpesvirus of the third type (CyHV-3) in the mollusk Rangia cuneata was experimentally confirmed.

\section{References}

1. Dong C., Weng S., Li W., Li X., Yi Y., Liang Q., He J. (2011) “Characterization of a new cell line from caudal fin of koi, Cyprinus carpio koi, and first isolation of cyprinid herpesvirus 3 in China". Virus Research. Vol. 161 (2). P. 140-149 [in English].

https://doi.org/10.1016/j.virusres.2011.07.016

2. Gomez D. K., Joh S. J., Jang H., Shin S. P., Jr C. H. C., Han J. E. et al. (2011) "Detection of koi herpesvirus (KHV) from koi (Cyprinus carpio koi) broodstock in South Korea". Aquaculture. Vol. 311 (1-4). P. 42-47 [in English].

https://doi.org/10.1016/j.aquaculture.2010.11.021

3. Kostenko S.O. (2018) "DNA vaccination of aquaculture facilities". Animal biology. Vol. 20 (4). P. 34-43 [in Ukrainian].

https://doi.org/10.15407/animbiol20.04.034

4. Spiridonov V.G. (2017) "Development of a method for DNA identification of sturgeon species using real-time polymerase chain reaction". Fisheries science of Ukraine. Vol. 2. P. 60-67 [in Ukrainian].

DOI: https://doi.org/10.15407/fsu2017.02.060 


\title{
УДОБРЕННЯ ПШЕНИЦ ТВЕРДОЇ ОЗИМОЇ
}

\section{Господаренко Григорій Миколайович}

доктор сільськогосподарських наук, професор, Уманський національний університет садівництва

\author{
Любич Віталій Володимирович, \\ доктор сільськогосподарських наук, професор, \\ Уманський національний університет садівництва
}

Калантир В'ячеслав Володимирович аспірант Уманський національний університет садівництва

Продуктивність сільськогосподарських культур $є$ найбільш мінливим й інтегральним показником їх життєдіяльності в якому акумулюється їх генетичний потенціал, родючість грунту, погодні умови і елементи технології вирощування [1]. Вирішення проблеми продовольчого зерна нерозривно пов'язано зі збільшенням зерновиробництва пшениці м'якої озимої. За узагальненими даними провідних наукових установ доведено [2-6], що якість зерна пшениці залежить насамперед від грунтово-кліматичних умов, біологічних особливостей сорту та технології вирощування. Україна $\epsilon$ провідним експортером пшениці, проте якість ії ще залишається досить низькою.

У передвоєнні роки вміст білка в зерні вітчизняної пшениці (Дніпропетровська, Харківська та Запорізька обл.) становив 18,5 \%, до 1958 р. вміст білка знизився спочатку до 15,5\%, а пізніше - до 13,4 \% [7]. Нині в Україні виробляють 10-12 \% продовольчої пшениці. Лише до 20-30 \% загальної кількості зерна належить до 2-3-го класів, а решта йде на фуражні цілі [8]. Навіть в умовах півдня України за останні роки лише 8 \% зерна пшениці м'якої озимої мали оптимальні для хлібопекарної промисловості показники [9]. Тому підвищення виробництва зерна пшениці з високою якістю - завдання державного рівня.

Основні причини отримання зерна низької якості є зменшення доз азотних добрив [8]. Без внесення добрив сформувати конкурентоспроможне зерно неможливо навіть на чорноземних грунтах після найкращих попередників. Для забезпечення конкурентноспроможності вітчизняного зерна слід отримувати врожайність пшениці озимої на рівні 5,0 т/га. Екологічна межа врожайності становить 7,0-9,0 т/га. Для отримання 8,0 т/га пшениці із вмістом білка в зерні $15 \%$ потрібно вносити 220 кг/га д. р. азотних добрив. Зазвичай рівень продуктивності пшениці озимої напряму залежить від забезпеченості азотним живленням. Так, на чорноземі типовому Харківської області приріст урожаю пшениці озимої на 88 \% визначався дією азотних добрив, а дія калійних добрив була не істотною [9]. 
Грунтово-кліматичний потенціал України дозволяє зробити виробництво зерна високоефективним і конкурентоздатним, адже рівень родючості грунтів нашої країни значно вищий, ніж у сусідніх державах [10]. Національний рекорд урожайності пшениці озимої перетнув межу 13 т/га, а потенційна врожайність кращих вітчизняних сортів вийшла на рубіж 14 т/га. В той же час за даними Держстату, середня врожайність пшениці озимої в Україні становить лише 3,26 т/га. До того ж ринкові умови змушують до ефективного використання ресурсів. Тобто, з одиниці площі необхідно одержати максимальний економічний ефект. При цьому високий урожай не завжди співпадає 3 одержанням високого прибутку [11]. Показовим є той факт, що останнім часом частка продовольчої пшениці (3-4-го класів) у багатьох регіонах України не перевищує 25\%. А за офіційними даними, частка продовольчої пшениці в загальному обсязі зерна цієї культури становить 54\%, або близько 6 млн т [12]. Низькою є якість і фуражного зерна, що призводить до перевитрат кормів [13].

На абіотичні фактори людина ще не може впливати, в той же час біотичні чинники можна контролювати, впливати й планувати. I це насамперед стосується добрив, які $є$ одним з найважливіших чинників підвищення продуктивності сільськогосподарських культур. Встановлено, що близько $50 \%$ приросту врожаю одержують від застосування добрив $[14,15]$. Кожен кілограм діючої речовини NPK дає приріст зерна пшениці на богарі, в середньому, 3-5 кг, а на зрошенні - 10-12 кг [16]. Тому першочерговим $є$ вирішення питання встановлення оптимальних доз і співвідношень елементів живлення внесених добрив.

Внесення мінеральних добрив не лише позитивно впливає на підвищення врожайності пшениці, але й істотно покращує якість зерна. Різні елементи живлення рослин неоднаково впливають на вміст білка в зерні. Так, при внесенні в основне удобрення азоту $\left(\mathrm{N}_{60}\right)$, вміст білка підвищувався на 1,98 абс. \%. Застосування фосфорно-калійних добрив знижувало вміст білка на 0,3 абс. \%. При застосуванні парних комбінацій NP i NK вміст білка збільшувався відповідно на 1,4 і 0,9 абс. \%, а повного мінерального добрива - на 1,0 абс. \% [17]. Тому аналіз даних інформації, що отримані в стаціонарних i короткотермінових дослідах стосовно закономірностей змін показників родючості грунтів, дасть можливість розробити і втілити у практику системи застосування добрив, які побудовані на засадах охорони грунтових ресурсів, посилення процесів саморегуляції, відновлення сталого функціонування агроекосистем [18, 19]. У поширених нині короткоротаційних сівозмінах зі значним насиченням зерновими культурами вплив попередників і систем удобрення на врожай та якість зерна пшениці озимої вивчений недостатньо [20, 21]. Особливо, це стосується пшениці твердої озимої. Система удобрення цього виду пшениці також вивчена недостатньо.

Важливим і поки що невикористаним резервом підвищення врожайності пшениці озимої $є$ застосування добрив. Пшениця озима вимоглива до умов живлення. Однак вплив добрив на ії продуктивність багатогранний і вивчений поки що не повністю. Отже, деякі питання вдосконалення агротехнології 
пшениці озимої з урахуванням грунтово-кліматичних умов мають бути вирішені та рекомендовані виробництву.

\section{Список літератури}

1. Господаренко Г. М., Черно О. Д. Урожайність пшениці озимої після різних попередників на фоні тривалого застосування добрив у сівозміні. Міжвід. темат. наук. зб. «Землеробство». 2015. Вип. 1. С. 28-31.

2. Рибалка О. І., Соколов В. М., Червоніс М. В. Якість урожаю зерна озимої пшениці 2006 року. Хранение и переработка зерна. 2006. №8. С. 16-20.

3. Довідник з вирощування озимої пшениці. В. Г. Влох, М. Я. Бомба, В.В. Лихочвор та ін. Львів: Українські технології, 1998. С. 54-56.

4. Лебідь С.М., Черенков А. В., Солодушко М. М. та ін. Особливості вирощування озимої пшениці у Степу України. Наук.-техн. бюл. МІП. 2008. Вип. 8. С. 335-344.

5. Рибалка О. І. Сортові особливості зерна як фактор стабільності якості. Хранение и переработка зерна. 2006. №5. С. 34-48.

6. Шевченко О. І., Турченюк Л. О. Стабільність якості зерна: фактор погодних особливостей чи невідповідність технологій. Наук.-техн. бюл. Миронівського інституту пшениці. 2008. Вип. 8. С. 371-387.

7. Крамарьов С. М., Жемела Г. П., Шакалій С. М. Продуктивність та якість зерна пшениці м'якої озимої залежно від мінерального живлення в умовах Лівобережного Лісостепу України. Бюлетень Інституту сільського господарства степової зони НААН України. 2014. №6. С. 61-67.

8. Балюк С., Заришняк А., Лісовий М. Підтягнути якість зерна. "The Ukrainian Farmer", 17. 05. 2017 p. http://www.agrotimes.net/ journals /article/ pidtyagnutiyakist-zerna.

9. Рибалка О. І., Моргун Б. В., Починок В. М. Сучасні дослідження якості зерна пшениці у світі: генетика, біотехнологія та харчова цінність запасних білків. Физиология и биохимия культурных растений. 2012. Т. 44. №1. С. 3-22.

10. Гринник I.В. Вплив попередників та системи удобрення на врожай та якість озимої і ярої пшениці в умовах Полісся. Автореф. дис. на здобуття наукового ступеня: автореф. дис. канд. с.-г. наук. за спеціальності 06.01.01 загальне землеробство К.:2000 15 с. Гриник Ігор Володимирович

11. Тимчук В., Іодковський В., Усова 3. Урожайність - потенційна і реальна. Зерно https://www.zerno-ua.com/journals/2017/avgust-2017god/urozhaynist-potenciyna-i-realna

12. Беркутова Н.С. Методы оценки и формирование качества зерна. - М.: Росагропромиздат, 1991. 206 с.

13. Верницький М. Україна: низький попит на фуражну пшеницю. Пропозиція. 2000. № 10. С. 107.

14. Господаренко Г.М. Система застосування добрив: К.: ТОВ «СІК ГРУП УКРӒ̈НА», 2018. 376 с.

15. Чабан В.Г. Вплив добрив та пестицидів на продуктивність рослинництва. Економіка АПК. 1999. № 11. С. 29-31. 
16. Марчук I. Сучасні добрива - на варті врожаю. Пропозиція. 2009. № 4. C. $42-45$.

17. Вирощування екологічно чистої продукції рослинництва / Е.Г. Дегодюк, В.Ф. Сайко, М.С. Корнійчук [та ін.]. К.: Урожай, 1992. 320 с.

18. Liubych V., Oliinyk O. Output of flattened cereals from emmer wheat after the radiation with high-frequency field.Theoretical and scientific bases of development of scientific thought. Abstracts of V International Scientific and Practical Conference. Rome, Italy, 2020. 21-23.

19. Liubych V., Oliinyk O. Application of electromagnetic field to produce flattened cereals from spelt wheat grains. Trends and directions of development of scientific approaches and prospects of integration of Internet technologies into society. Abstracts of VI International Scientific and Practical Conference. Stockholm, Sweden 2021. 20-22.

20. Liubych V., Stratutsa Y. The importance of triticale in diversification of grain production. Science and practice, problems and innovations. Abstracts of VII International Scientific and Practical Conference. Ottawa, Canada 2021. 10-12.

21. Liubych V., Stratutsa Y.The importance of triticale in the production of groats. Problems and tasks of modernity and approaches to their solution. Abstracts of VIII International Scientific and Practical Conference. Tokyo, Japan 2021. 11-13. 


\title{
ПАСМО ЛЬОНУ (MYCOSPHAERELLA LINICOLA NAUMOV) B УKPAÏHI
}

\author{
Станкевич Сергій Володимирович \\ кандидат сільськогосподарських наук, доцент \\ Харківський національний аграрний університет ім. В.В. Докучаєва
}

Збудник захворювання пасмо льону гриб Mycosphaerella linicola Naumov (= M. linorum (Wollenweber) García-Rada, Phyctaena inicola Spegazzini, Septogloeum linicola Spegazzini, Septoria linicola (Spegazzini) Garassin, Sphaerella linorum Wollenweber) належить до відділу Ascomycota (Аскомікотові), класу Dothideomycetes (Дотідієві), порядку Capnodiales (Капнодіальні), родини Mycosphaerellaceae (Мікосферелові).

Основним живителем патогена $\epsilon$ льон звичайний довгунець. Також уражуються інші види роду льон Linum, наприклад льон озимий. Гриб уражує всі надземні частини рослини з моменту сходів до кінця вегетації. Під час раннього ураження льону у фазі «ялинки» рослини гинуть, під час пізнього ураження хвороба пошкоджує волокно, знижує врожай насіння, волокно стає ламким, втрачає міцність, а в уражених коробочках насіння майже не формується, або воно щупле та неповноцінне. За сприятливих для розвитку хвороби породних умов пасмо може завдавати значних збитків господарствам, уражуючи волокно й насіння, зниження врожаю досягає 50-70 \%, при цьому значно погіршується його якість.

Уперше хворобу було виявлено в Аргентині в 1911 р. Нині вона поширена в ряді країн Європи (Бельгія, Білорусь, Великобританія, Греція, Італія, Литва, Росія, Румунія, Сербія, Словенія, Україна, Франція, Хорватія, Угорщина, Чорногорія, Швеція), Азії (Казахстан, Туреччина), Африки (Ефіопія, Кенія, Танзанія, Туніс), Північної Америки (Канада, США), Центральної Америки (Мексика), Південної Америки (Аргентина, Бразилія, Перу, Уругвай), Австралії та Океанії (Австралія, Нова Зеландія) (рис. 1).

Збудник може бути у зразках насіння, яке зберігалося більше року. Також гриб зберігається на рослинних рештках льону або в грунті протягом 4 років. Перитеції утворюються на старих відмерлих стеблах, а вивільнені аскоспори 3 потоком повітря заражають усі наземні органи рослин льону. Зазвичай насіння головне джерело інфекції, але пікніди також беруть участь у передачі захворювання. Пікніди утворюються на плямах, пікнідіоспори (конідії) виділяють зі слизу. Такі спори не розсіюються вітром, а переносяться краплинами дощу, тваринами й людьми. Швидке розповсюдження захворювання спостерігається в період дозрівання льону. Вважають, що це пов'язано 3 утворенням вторинних конідій, які переносяться вітром i проростають iз конідієспор. Утворенню плям і подальшому поширенню хвороби сприяють висока відносна вологість повітря, рясні опади й температура понад $20^{\circ} \mathrm{C}$. Збудник має три стадії розвитку: пікнідіальну, конідіальну і сумчасту. За зараження рослин міцелій гриба, не пошкоджуючи флоему, проникає в 
крохмаленосні клітини, зменшує вміст крохмалю, необхідний для росту луб'яних пучків і в такий спосіб, виснажує рослину.

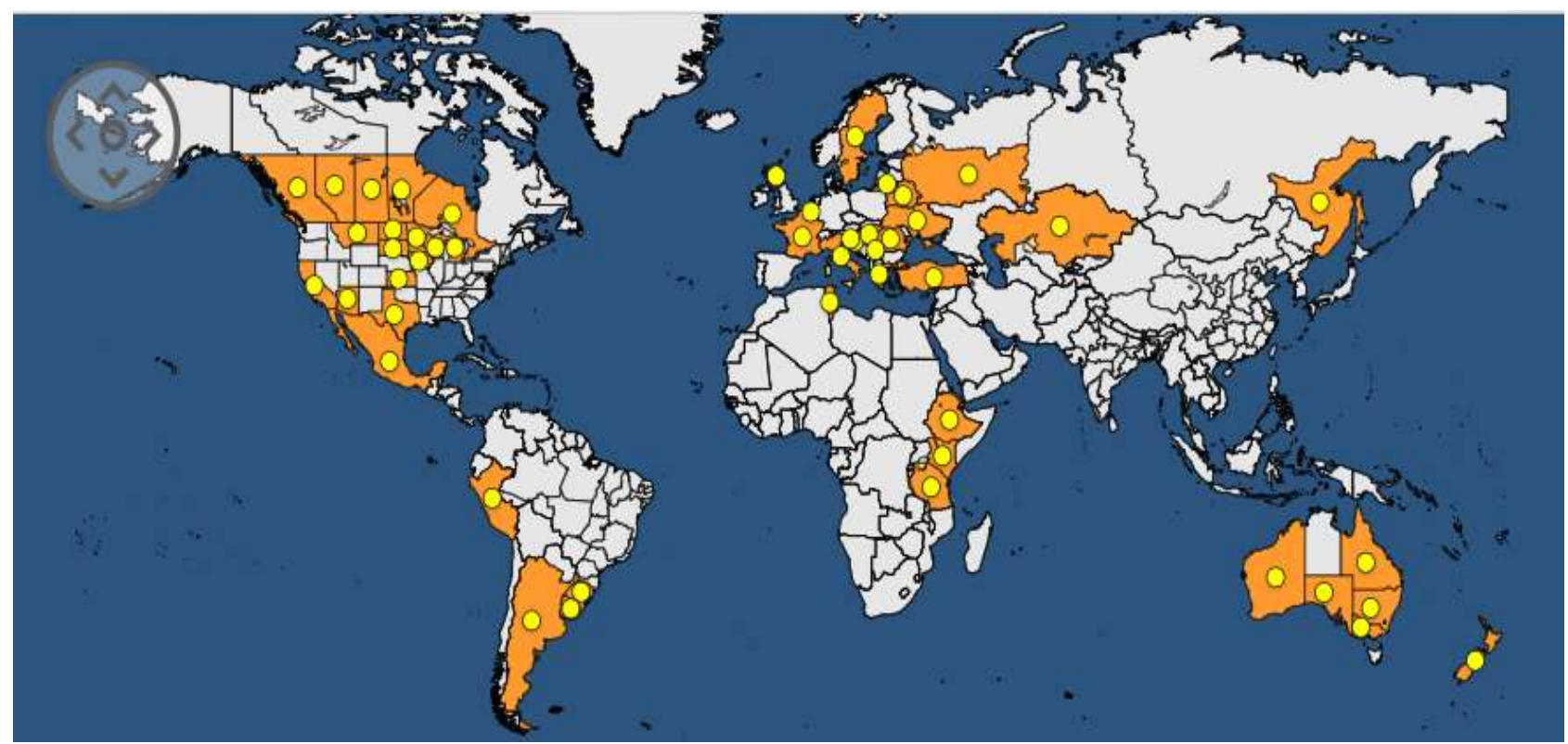

Рис. 1. Світовий ареал Mycosphaerella linicola Naumov

Пікніди розташовані переважно в центрі плям на всіх уражених частинах рослини й добре помітні під час огляду їх за допомогою лупи. Пікніди формуються всередині коробочок на перегородках, іноді на самому насінні у вигляді світлих горбків, розташованих, головним чином, біля зародкової частини. Велика кількість пікнід формується на чашолистиках і квітконіжках. Пікніди розміром 62-125 мкм, являють собою напівзанурені в рослинну тканину плями (рис. 2) округлої, еліпсоїдальної, сочевицеподібної форми з ніжною прозорою світло-коричневою оболонкою й широким отвором на верхівці. Пікноспори безбарвні, паличкоподібні, прямі або трохи зігнуті, із трьома перегородками, розміром $12-28 \times 1,5-3,0$ мкм $(19,0-34,5 \times 2,7-3,4$ мкм). Згодом на відмерлих тканинах стебел можливе формування сумчастого спороношення у вигляді перитеціїв, розміром 70-100×6090 мкм. Усередині перитеціїв $є$ мішкоподібні прозорі утворення - сумки або аски, у яких містяться аскоспори. Аскоспори безбарвні, прямі або дещо зігнуті, з однією поперечною перегородкою, їхні розміри 11-17 × 2,5-4,0 мкм.

Гриб уражує всі наземні частини рослини з моменту появи сходів до кінця вегетації. Симптоми на рослинах льону виявляються в ранній фазі його росту на сім'ядольних листочках, після чого хвороба переходить на справжні листочки, стебла й, поширюючись знизу догори по рослині, уражує бутони й коробочки (рис. 2). Сім'ядольні листки стають коричневими, підсихають i вкриваються спороношенням гриба - пікнідами, а потім опадають. На справжніх листках хвороба проявляється у вигляді плям, здебільшого округлих, колір їх змінюється від зеленувато-жовтого на ранніх фазах до темно-коричневого пізніше. Уражені листки поступово засихають, скручуються й опадають, оголюючи стебло. Ураження стебла починається 3 його нижньої частини у вигляді невеликих ділянок видовженої форми. Спочатку вони не оточують стебло цілком, лише із часом, збільшуючись у розмірах, плями опоясують стебло 
повністю. У цій фазі уражені коричневі ділянки тканини чергуються із зеленими смугами здорової тканини, надаючи стеблам і гілочкам строкатого вигляду.

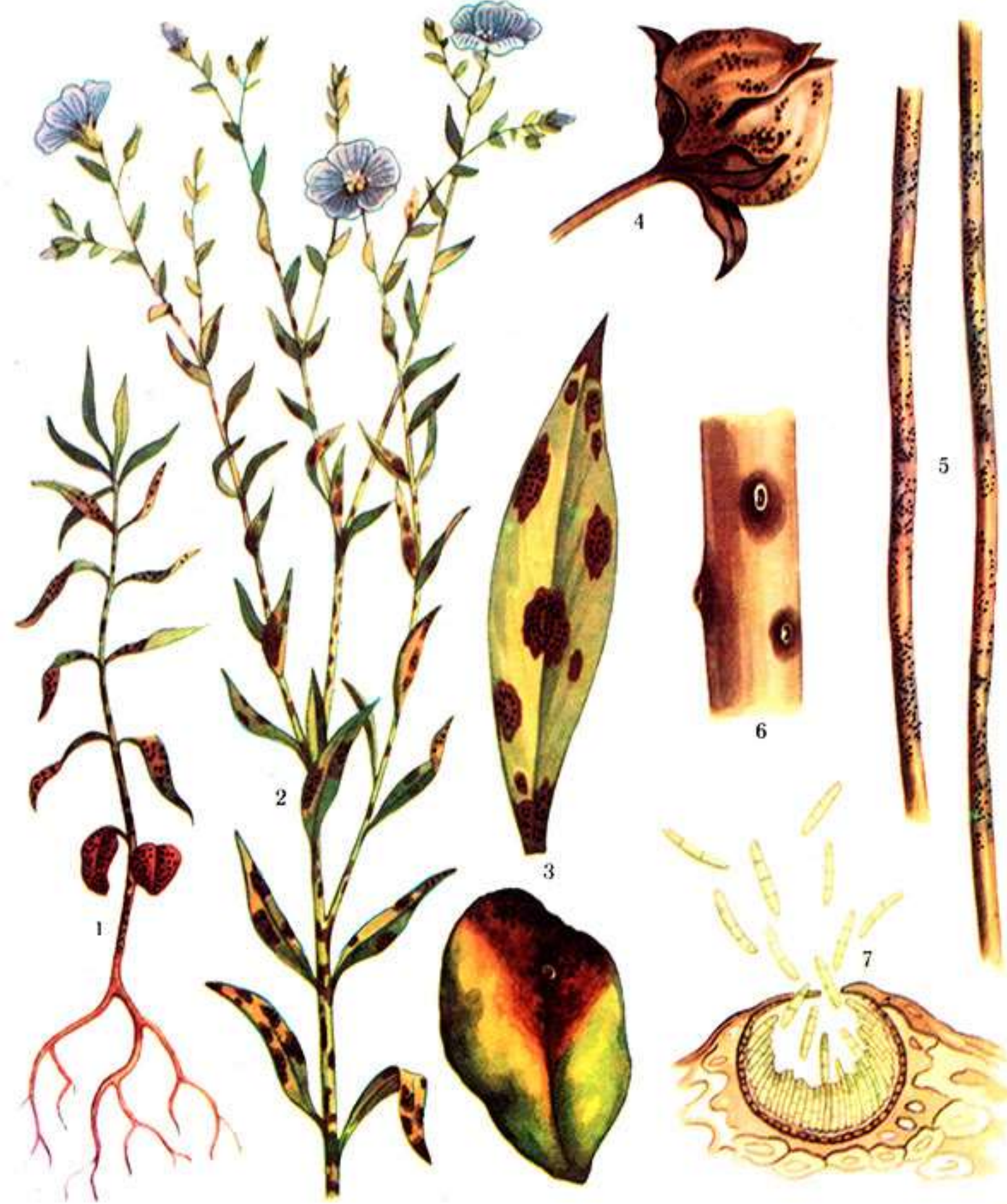

Рис. 4.16. Пасмо льону:

1) уражені сходи; 2) уражена рослина; 3) уражений листок; 4) уражена коробочка; 5) соломини з пікнідами; 6) пікніди на соломині; 7) пікніда з пікноспорами у розрізі

Основним джерелом первинного ураження посівів льону є заражене насіння та грунт. Під час вегетації захворювання розповсюджується вітром, краплями дощу, комахами.

Заборонено завезення насіннєвого матеріалу льону із заражених зон країн поширення патогена. Насіннєвий матеріал дозволено завозити за умови відсутності захворювання, що встановлюють шляхом обстежень та 
фітосанітарної експертизи місць вирощування у період вегетації. При завезенні насіннєвий матеріал підлягає обов'язковому інспектуванню, 3 подальшою фітосанітарною експертизою. У разі виявлення захворювання насіннєвий матеріал заборонено використовувати для посіву, його відправляють на переробку. Рослинні рештки спалюють.

Для своєчасного виявлення захворювання проводяться обстеження посівів льону у фазі «ялинки» та за тиждень до збирання врожаю льону. У разі виявлення осередку захворювання запроваджують карантинний режим. На зараженій ділянці насіння льону можна висівати лише через 6-7 років.

Насінницькі виробничі посіви, де виявлено захворювання, вибраковують, а зібране насіння складують окремо i використовують лише на технічну переробку. Заражене льоноволокно переробляють у першу чергу, з дотриманням фітосанітарних вимог, а рештки спалюють. 


\title{
НЕГАТИВНИЙ ВПЛИВ ТА РОЗВИТОК ТРАНСПОРТУ В ФОРМУВАННІ АРХІТЕКТУРНО-ПРОСТОРОВОЇ СТРУКТУРИ МІСТА
}

\author{
Солнцев Артем Геннадійович, \\ старший викладач
} Харківський національний університет міського господарства імені О. М. Бекетова, Україна

Усачова Олена Юріївна, канд. архіт., доцент Харківський національний університет міського господарства імені О. М. Бекетова, Україна

\section{Богданова Лариса Олегівна,}

старший викладач

Харківський національний університет міського господарства імені О. М. Бекетова, Україна

Прогрес розвитку цивілізації невіддільний від історії розвитку транспорту. 3 розширенням держав, будівництвом міст, з розселенням людей на все більш великих територіях, зростанням торгівлі, темпи розвитку транспорту постійно збільшувалися.

На даний час загальна чисельність легкових автомобілів має тенденцію до значного зростання. Масова автомобілізація породжує величезну кількість взаємопов'язаних між собою проблем:

- соціальных;

- економічних;

- екологічних;

- санітарно-гігієнічних та ін.

У великих і найбільших містах, забудова в яких на початку-середині XX століття велася в розрахунку на розвиток, головним чином, громадського транспорту для обслуговування пасажирів, не була розрахована на збільшення зростання індивідуальних транспортних засобів. Індивідуальний автотранспорт частіше поглинає відкриті простори міста, ускладнюючи контакт людини 3 природним оточенням. На сьогоднішній момент автомобілі зберігаються в самих невідповідних місцях: на тротуарах, газонах і навіть на дитячих майданчиках.

Населення міст все більше відчуває кризовий стан міського середовища, що включає місця зберігання автомобілів, незручність користування парковками, постійні конфлікти рухомого і нерухомого автотранспорту. Зростає вуличний травматизм. Вплив транспортних засобів, в тому числі їх паркування, часто 
призводить до дегуманізації міських просторів, дискомфорту і екологічної кризи міського середовища.

За ступенем руйнівного впливу на міське середовище транспортні комунікації і їх об'єкти відносяться до числа стабільно агресивних, тому стосовно до них відчувається максимальна необхідність пошуку ресурсів природи, здатних знизити гостроту існуючих проблем. Нерівномірність просторового розподілу транспортних функцій створює зони екологічної напруженості поблизу міських вокзалів, уздовж автомобільних магістралей безперервного руху особливо з торговими комплексами. Кожна з перерахованих зон з точки зору характеру впливу на міське середовище має свою специфіку, але всі вони можуть знайти інші якості в разі раціонального застосування природних елементів і вдосконалення транспортної та пішохідної інфраструктури найбільшого міста. Слід зазначити, що транспортно-пішохідна інфраструктура $\epsilon$ по-суті основним планувальним каркасом міста. Вона створювалася поетапно в історично сформованих містах України і має цілий ряд особливостей формування, які обумовлені розвитком певних транспортних засобів.

В даний час високі темпи урбанізації міського середовища вимагають пошуків створення більш раціональної транспортної системи міста з вирішенням проблем паркування індивідуального автотранспорту.

Більшість теоретичних і прикладних досліджень в області організації транспортної системи міста спрямовані на вивчення пересувань (напрямки $\mathrm{i}$ кількості), аналіз конфігурації вулично-дорожньої мережі, вивчення роботи існуючих і проєктованих маршрутних мереж, прогнозування і моделювання транспортної рухливості населення, підвищення ефективності роботи міського транспорту в цілому, але при цьому недостатньо уваги приділяється на створення архітектурних об'єктів, що забезпечують більш досконале обслуговування населення за допомогою створення різноманітних парковок. У роботі наводиться їх більш чітка класифікація. Вперше дається визначення «паркінг». Як об'єкт транспортно-пішохідної інфраструктури міста він отримує розвиток в XXI ст.

В проєктній практиці i наукових дослідженнях цей термін почали застосовувати для характеристики будівель із зберіганням транспортних засобів по вертикалі. Такі будівлі роблять міське середовище більш гуманним.

«Паркінг» являє собою середовищної об'єкт з певним об'ємно-просторовим рішенням його архітектурного середовища, призначений для зберігання автотранспортних засобів по вертикалі.

Паркінги з'явилися для поліпшення екологічних, естетичних характеристик міського середовища і комфортного обслуговування населення з транспортними засобами, але вони також потребують подальшого вдосконалення формування їхнього середовища 3 урахуванням появи нових технологій $\mathrm{i}$ аналізом позитивного досвіду їх функціонування.

Необхідність вдосконалення формування архітектурного середовища паркінгів обумовлена наступними проблемами: 
- зростання добробуту населення спричиняє збільшення автомобілізації $\mathrm{i}$ необхідність зберігання особистого автотранспорту в сучасних, екологічно безпечних паркінгах, якими в даний час наші міста практично не оснащені;

- стихійна поява місць паркування в сельбищних зонах міст призводить до різкого зниження санітарно-гігієнічних показників міського середовища і до негативного впливу на здоров'я городян;

- масове впровадження вуличних і позавуличних місць паркування при житлових і громадських об'єктах у вітчизняній архітектурно-містобудівній практиці не тільки робить негативний естетичний вплив на міське середовище, але і знижує споживчі якості громадських будівель;

- поява великої кількості парковок в сучасній вітчизняній практиці призводить до деградації і руйнації ландшафтних компонентів міського середовища, територія яких «захоплюється» місцями зберігання автомобілів,

- масове будівництво парковок спирається на існуючу нормативнорекомендаційну базу, яка не відповідає сучасним вимогам раціонального природокористування, енергозбереження, пожежобезпечного i, особливо, повноцінного задоволення потреб сучасної людини.

В даний час паркінги в великих і найбільших містах повинні стати активними об'єктами в формуванні архітектурно-просторової структури міста, яка поліпшує іiі еколого-естетичні характеристики, що сприяють гуманізації середовища життєдіяльності.

\section{Список літератури:}

1. Вотінов М. А. Гуманізація транспортно-пішохідної інфраструктури крупнішого міста : монографія / М. А. Вотінов, О. В. Смірнова; Харк. нац. ун-т. міськ. гос-ва ім. О.М. Бекетова. - Х.: ХНУМГ, 2020. - 120 с.

2. Вотінов М.А., Чубарова Д.С. Специфіка та перспективні тенденції формування архітектурного середовища паркінгів в міському середовищі. Development of modern science: the experience of Europen countries and prospects for Ukraine: monograph / edited by authors. 3rd ed. Riga, Latvia : «Baltija Publishing», 2019. P. 617-640.

3. Вотінов М.А., Чубарова, Д.С. Паркінги як об’єкти гуманізації міського середовища. Сучасні проблеми архітектури та містобудування. / Київ. нац. ун-т буд-ва і архіт. - Київ: КНУБА, - 2019. - Вип. 53. - С. 116-126.3. 


\title{
THE PECULIARITIES OF SUCCESSFUL CAPITALIZATION AND MUSEUM SPACE REVIVAL
}

\author{
Koniukhov Serhii \\ Ph.D., Assistant \\ Lviv Polytechnic National University
}

Ways to transform the museum from a permanent place of preservation of cultural heritage artifacts to an open and dynamic social space of social interaction was explored by N. Ivanova [1].

O. Kryvoruchko considers methods of revitalization of public space in the process of revitalization of the urban environment. In her work, she focuses on the example of workshops on the revitalization of Sq. Customs in Lviv [2].

According to the results of sociological research, only $1 \%$ of respondents visit museums once every two weeks, $4 \%$ once a month, $7 \%$ once every three months, $17 \%$ once every six months and $71 \%$ do not visit at all [3, p. 77]. There are several reasons for such disappointing statistics: on the one hand, there is no time to visit the museum when new existing economic structures have not yet been created, and unemployment and low incomes accompany people's daily lives. On the other hand, during state communism, museum visits were a must for various organizations, such as pioneers and trade unions.

Compulsory museum visits also occur in democracies, but mostly at school and in some families. As a rule, visitors must decide voluntarily whether to go to the museum or not. In order to have as many such voluntary decisions as possible, museums need to do something. In any case, it is worth focusing on making museums really interested in showing their holdings to the general public and being ready to attract tourists from other countries.

The quality of a museum is not a static thing. The permanent exhibition, which seemed excellent yesterday, does not surprise anyone in a few years. In our fleeting times, museums must constantly monitor themselves, strive for higher standards, strengthen themselves more professionally, and become more attractive. The museum must constantly attract attention.

It is interesting, given the strategic development of the museum, to get an answer to the question: "Who is our (potential) visitor?", Because not every inhabitant of the country is a potential fan of museums.

There are two ways to attract tourists: 1) tourists who come to the city or village have different opportunities - for example, according to the booklet in the hotel, information from the tourist center to find a way to your museum; 2) through successful cooperation with tourism companies, it would be possible to include visits to the historical and cultural heritage of the region in the program of visits. 
After all, anyone who wants to attract many visitors must first clearly say what is special about it. These can be unique collections, historical or very modern museum expositions, didactically well-crafted inscriptions, as well as an attractive location, a restaurant next to the museum. However, the huge number of exhibits is not an argument for visitors, because visitors' time is also limited. Therefore, museums should focus only on their peculiarities, but not the size of the funds.

The potential of the exhibition is exhausted quickly, so only pupils or students remain in the museums. Most residents of a town or village do not want to go to the museum again if they have seen its permanent exhibits at least once in their lives. Therefore, it is necessary to constantly arouse interest in potential visitors. This becomes possible through the use of cooperation with other museums to change the exhibition, through the display of what is still stored in the funds [5].

The museum must have its own strategy for its collections. The museum's approach to reality is diametrically opposed to the usual behavior in our consumer society. Anyone who does not want to throw away some old things from the past, makes a museum. However, in the absence of a strategic approach, you can get everything you can, someday it will come in handy [4]. In this way, this logical mistake often leads to others: pull everything you can get to the point of collapse, or give yourself some temporary advice until you build or build something. This has a negative effect when there are huge funds and small exhibition areas - so in large ethnographic museums around the world exhibit only 2-3\% of funds. In this case, scientists can not pay for the processing of funds, and registration and inventory is slow (if at all seems promising) [5].

Many museums still think that visitors do not have to show what they want to see, but what they need to see. After all, such museums do not see themselves as service providers, but as meters.

Museums focus their efforts on attracting visitors not only to the markets, but also to the markets of finance, personnel and supplies. They are divided into interest groups, which can be considered as customers of the museum-manufacturer of services. Stakeholders include: public institutions; sponsors, philanthropists; neighborhood; other museums and communities; universities; firms, freelancers; (potential visitors). The purpose of the modern tourist is not only to visit museums or theaters. He also wants to sit in a cafe, go with children to the amusement park, go shopping, buy souvenirs and just change the situation. To become a cultural and tourist center, the region must qualitatively change the whole environment, make it comfortable, safe, interesting and "friendly" to tourists. Reformatting the region for cultural and tourism activities is the task of the entire local society.

In this regard, additional services are also aimed at popularizing the activities of the museum: gastronomy, museum shop, work with the public, holding conferences, concerts, etc. In this case, cultural tourism appears to us as a symbiosis of the economy with the sphere of culture. After all, the museum is not only about getting acquainted with the cultural heritage of the city or village, but also the inclusion of tourists in the modern cultural environment, so that he took an active part in cultural events and practices specific to the area. To this end, to promote cultural programs and projects 
that create an "atmosphere of the place", its special character, thereby increasing its value: libraries, theaters, music, dance, museums, exhibitions, festivals and more.

Special marketing tools are a well-thought-out time, focused on the free time of the visitor, entrance fee, discounts, museum cards, tours, the area near the museum, the presence on the Internet, the logo of the museum. These are the minimum prerequisites for a successful proposal. Visitor orientation and marketing are absolutely necessary for museums, the difference from the old methods is a systematic reorientation to the institution of the service provider and in monitoring the achievement of goals. Thus, the commercialization and transformation of the environment requires: space for events, exhibition spaces and individual galleries, art market or shop, recording activities and art projects on the Internet and the media.

The museum as a whole, and hence its external and internal image, is a communicator and a means of transmitting information. Cultural tourism therefore consists in getting acquainted with the culture and cultural environment of the place of visit, including the landscape, acquaintance with the traditions of the inhabitants and their way of life, artistic culture and art, various forms of leisure of local residents. Cultural tourism may include visits to cultural events, museums, cultural heritage sites, contacts with local residents.

\section{References:}

1. Ivanova N. Actualization of the museum as a cultural-educational center and open public space (on the example of the Melitopol City Museum) / N. Ivanov // City: history, culture, society. E-Journal of Urban Studies. - 2017. - № 3. - pp. 123 - 135.

2. Kryvoruchko O. Yu. Methods of revitalizing public space, as an example of a workshop on the revitalization of the Customs Square in Lviv / O. Kryvoruchko // Bulletin of the National University "Lviv Polytechnic". Architecture. - 2015. - № 816. - pp. 125-132.

3. Report of the sociological research "Quality of life in Lviv. Social Monitoring 2016 ", conducted by the City Institute together with the Fama Sociological Agency. [Electronic resource]. - Access mode: http://zaxid.net/news/showNews. do? pravilni_lvivyani\&objectId $=1401158$

4. Stransky, Zbyněk Z. Ten Years International Summer School of Museology. In STRÁNSKÝ, Zbyněk Z. (ed.). Museology for Tomorrow's World. Munich: Christian Müller-Straten. - 1997. - pp. 143-151.

5. Muller-Straten, Christian. The Contribution of Zbynek Z. Stransky to Museology within the Frame of the Brno Museology School. Museum aktuell. - 2007. - pp. 19-22. 


\title{
ЕКОЛОГІЧНА ОЦІНКА ПРИ БІОІНДИКАЦІЇ ВОДОЙМ
}

\author{
Курбатова Інна Миколаївна, \\ д. б. н., професор, \\ Національний університет біоресурсів і \\ природокористування України, м. Київ, Україна \\ Захаренко Микола Олександрович, \\ д. б. н., професор, \\ Національний університет біоресурсів і \\ природокористування України, м. Київ, Україна \\ Чепіль Людмила Василівна, \\ к. с.-г. Н., доцент, \\ Національний університет біоресурсів і \\ природокористування України, м. Київ, Україна
}

Вступ. Зростання обсягів забруднень, відходів тваринництва, птахівництва та переробних підприємств, що надходять до природних та штучних водойм потребує оцінки існуючої та потенційної небезпеки тих змін, що відбуваються у водних екосистемах під впливом токсичних факторів.

Для моніторингу якості водного середовища та оцінки токсичності забруднюючих речовин все більшого значення набуває метод біотестування, який у поєднанні з гідрохімічним складом дозволяє дати оцінку змінам, що відбуваються у водній екосистемі за умов антропогенного впливу [1].

Метою роботи було визначення токсичності забруднень стічних вод свинарських підприємств та вивчення впливу деяких факторів на культивування тест - об'єктів.

Методи досліджень. В якості тест-об'єктів використовували планктонних ракоподібних Daphnia magna. Безхребетних відловлювали в природних біотопах переважно в Голосіївських ставках і вирощували в лабораторних умовах, адаптуючи їх до умов утримання. 3 цією метою до природної води, в якій знаходились дафнії, поступово додавали відстояну (протягом 3 діб) водопровідну воду. Детритні відкладення відбирали за допомогою піпетки 3 резиновою грушею.

Вивчення впливу забруднень стічних вод на лабораторну культуру Daphnia magna проводили в умовах гострих експериментів протягом 3 діб.

Лабораторну культуру Daphnia magna вирощували на відстояній воді при регулярній підгодівлі кінським гноєм (1,5 г/л кожні 7 діб). 
За показник токсичності стічних вод слугувала концентрація амонійного азоту $\left(\mathrm{NH}_{4}{ }^{+}\right)$визначення якого проводили за [2].

Розрахунок концентрації робочих розчинів проводили на початок досліду.

Для встановлення меж концентрацій токсиканту було досліджено 3 рівні даної сполуки: 4,0 мг/л (1), 8,0 мг/л (2), 40,0 мг/л (3). Розчини готували на водопровідній воді. В якості контролю використовували розчин $\mathrm{NH}_{4} \mathrm{Cl}$.

Досліди проводили у трьох повторностях для кожної із досліджуваних концентрацій токсиканту при температурі $21-25{ }^{\circ} \mathrm{C}$ та при освітленні лампами ДС-30. Загальний об'єм розчину становив 300 мл.

Тест-організми в середовище вносили в кількості 10 екземплярів Daphnia magna на один стакан. Годівлю безхребетних на час дослідів не проводили. Величину $\mathrm{pH}$ середовища контролювали іономіром I-130, а вміст кисню i температуру води - за допомогою (оксиметра виробництва Тартуського університету [3].

Задані в дослідах концентрації досягались шляхом додавання розрахункових об'ємів стічної води і розчину відповідної концентрації.

Результати власних досліджень. Оскільки досліди проводили при температурі $21-25^{\circ} \mathrm{C}$ і освітленні люмінесцентними лампами, можна було очікувати зменшення об'ємів робочих розчинів за рахунок випаровування, що могло призвести до зміни концентрації $\mathrm{NH}_{4}{ }^{+}$.

Проведеними дослідженнями встановлено, що за час тридобової експозиції втрати води складали при об’ємі 500 мл - 6 \pm 0,5\%, 300 мл - $11 \pm 1,2 \%, 200$ мл $20 \pm 1,4 \%$.

Такі втрати можуть істотно впливати на характеристику робочих розчинів, змінюючи концентрацію окремих речовин, тому склянку в процесі культивування накривали скляною пластиною.

Вивчення динаміки вмісту розчинного кисню у воді дослідних зразків як в присутності дафній так і без них показало, що спостерігається зниження рівня даної сполуки до $79-80 \%$ від його насиченості. Таке зниження вмісту розчиненого кисню у воді не може вважатись лімітуючим фактором, який може впливати на вірогідність результатів досліду внаслідок виникнення дефіциту кисню.

Дослідження величини рН води в дослідних зразках також показало, що цей показник практично не змінювався і залишався в межах контролю.

Підвищення $\mathrm{pH}$ води за час досліду можна пояснити тим, що за даних умов карбонатна рівновага розчину зсувається в бік утворення іонів $\mathrm{CO}_{3}{ }^{2-}$.

Вплив забруднень стічних вод свинарських підприємств на виживаність дафній за умов їх трьохдобового культивування у середовищах 3 різною концентрацією забруднень наведено в таблиці 1. 
Таблиця 1.

Виживаність дафній за 3-х добовий період експозиції

\begin{tabular}{|c|c|c|c|c|c|c|c|}
\hline \multirow{4}{*}{$\begin{array}{l}\text { Тривалість } \\
\text { експозиції }\end{array}$} & \multicolumn{3}{|c|}{ Дослід } & \multicolumn{4}{|c|}{ Контроль } \\
\hline & \multicolumn{3}{|c|}{$\mathrm{NH}_{4}{ }^{+}$стічні води } & \multicolumn{3}{|c|}{ Сольовий $\mathrm{NH}_{4}{ }^{+}$} & $\begin{array}{c}\text { Водопровідна } \\
\text { вода }\end{array}$ \\
\hline & \multicolumn{3}{|c|}{$\begin{array}{c}\text { Співвідношення } \\
\text { живих і загиблих } \\
\text { дафній }\end{array}$} & \multicolumn{3}{|c|}{$\begin{array}{c}\text { Співвідношення } \\
\text { живих і загиблих } \\
\text { дафній }\end{array}$} & $\begin{array}{c}\text { Співвідноше } \\
\text { ння живих і } \\
\text { загиблих } \\
\text { дафній }\end{array}$ \\
\hline & I & II & III & $\mathrm{I}$ & II & III & \\
\hline \multicolumn{8}{|l|}{1 доба } \\
\hline вранці & $30 / 0$ & $30 / 0$ & $30 / 0$ & $30 / 0$ & $30 / 0$ & $30 / 0$ & $30 / 0$ \\
\hline ввечері & $30 / 0$ & $30 / 0$ & $30 / 0$ & $30 / 0$ & $30 / 0$ & $30 / 0$ & $30 / 0$ \\
\hline \multicolumn{8}{|l|}{2 доба } \\
\hline вранці & $30 / 0$ & $30 / 0$ & $30 / 0$ & $30 / 0$ & $30 / 0$ & $30 / 0$ & $30 / 0$ \\
\hline ввечері & $30 / 0$ & $27 / 3$ & $28 / 2$ & $30 / 0$ & $30 / 0$ & $29 / 1$ & $30 / 0$ \\
\hline \multicolumn{8}{|l|}{3 доба } \\
\hline вранці & $28 / 2$ & $25 / 5$ & $24 / 6$ & $30 / 0$ & $28 / 2$ & $29 / 1$ & $30 / 0$ \\
\hline
\end{tabular}

Порівнюючи результати досліджень слід відмітити, що у пробах зі стічною водою через 48 годин експозиції виживаність дафній становила 90-94\% при тенденції зниження на третю добу до 80-83 \%, при цьому в контрольному варіанті виживаність дафній на другу добу становила 97\% і практично не змінилася на третю добу. В дослідному варіанті спостерігається незначний вплив концентрації забруднень на виживаність дафній: 1 доба - 94\%, 2 доба $83 \%, 3$ доба - 80\%, тоді як у контрольному варіанті цього впливу не відмічено.

Висновки. Аналізуючи отримані результати можна зробити висновок, що у дослідному варіанті на виживаність дафній впливає не стільки амонійний нітроген, а його комплексна дія з органічною складовою стічних вод.

Додавання стічних вод свинарських підприємств до середовища з дафніями підвищує вміст амонійного азоту, знижує рівень кисню, змінює величину $\mathrm{pH}$ води та зменшує до 80-83\% виживаність дафній.

\section{Список використаної літератури.}

1. Кватернюк С.М. Контроль екологічної безпеки стічних вод за допомогою мультиспектрального методу та біоіндикації по фітопланктону // Вісник Вінницького політехнічного інституту. 2017. № 6. 26-33 с.

2. $\quad$ ISO 10523:1994. Качество воды. Определение рН. - 1994.

3. КНД 211.1.4.030-95. Методика фотометричного визначення амонійіонів з реактивом Неслера в стічних водах. - К., 1995. 


\title{
THE NEED FOR A TERRITORIAL ORGANIZATION OF DIGITAL BANKING
}

\author{
Yanyshyn Yaroslav, \\ Ph.D., Associate Professor, \\ director of the department in Lviv \\ Old Polish University in Kielce \\ Markiv Galyna, \\ Ph.D., Associate Professor \\ Lviv National Agrarian University
}

In an era of rapid development of information technology, banking is undergoing significant revolutionary change. Many banking institutions, especially abroad, already offer customers a range of technologies that allow them to use financial services in electronic format, including receiving information and services on social networks or performing complex financial transactions on a smartphone.

The market of banking services in Ukraine is growing very slowly due to the weak overall economic development of the country, uneven regional development, slowdown in the growth of welfare and formed only a few banks with a significant customer base. This situation requires banks to find other effective points of development in order to strengthen their position. And, in our opinion, this point of banking growth can be digital banking. It is simple and easy to use and will allow the client to receive banking services (including consulting) regardless of the channel it uses.

Undoubtedly, digital banking is an important localizer of the customer base, an underestimated source of income (primarily commission) and a way to achieve a competitive advantage in the banking services market. And the management of domestic banking institutions must understand that it is the quality of digital banking services and ease of use of banking services will gradually displace in the minds of customers such an important criterion today as price.

The banking institution (digital bank) as an available consultant, supplier, coordinator, aggregator and service provider must know its client, all his desires, needs and capabilities. And to better meet these needs, the bank must first think about the customer, and only then about the banking product and service. In addition, the bank as a regional institution should increase its reputation and inspire confidence in the client of its region in order to form a long-term and mutually beneficial relationship with him. And for this it must act actively and wisely, using social networks and relying on individual interaction (Fig. 1). 


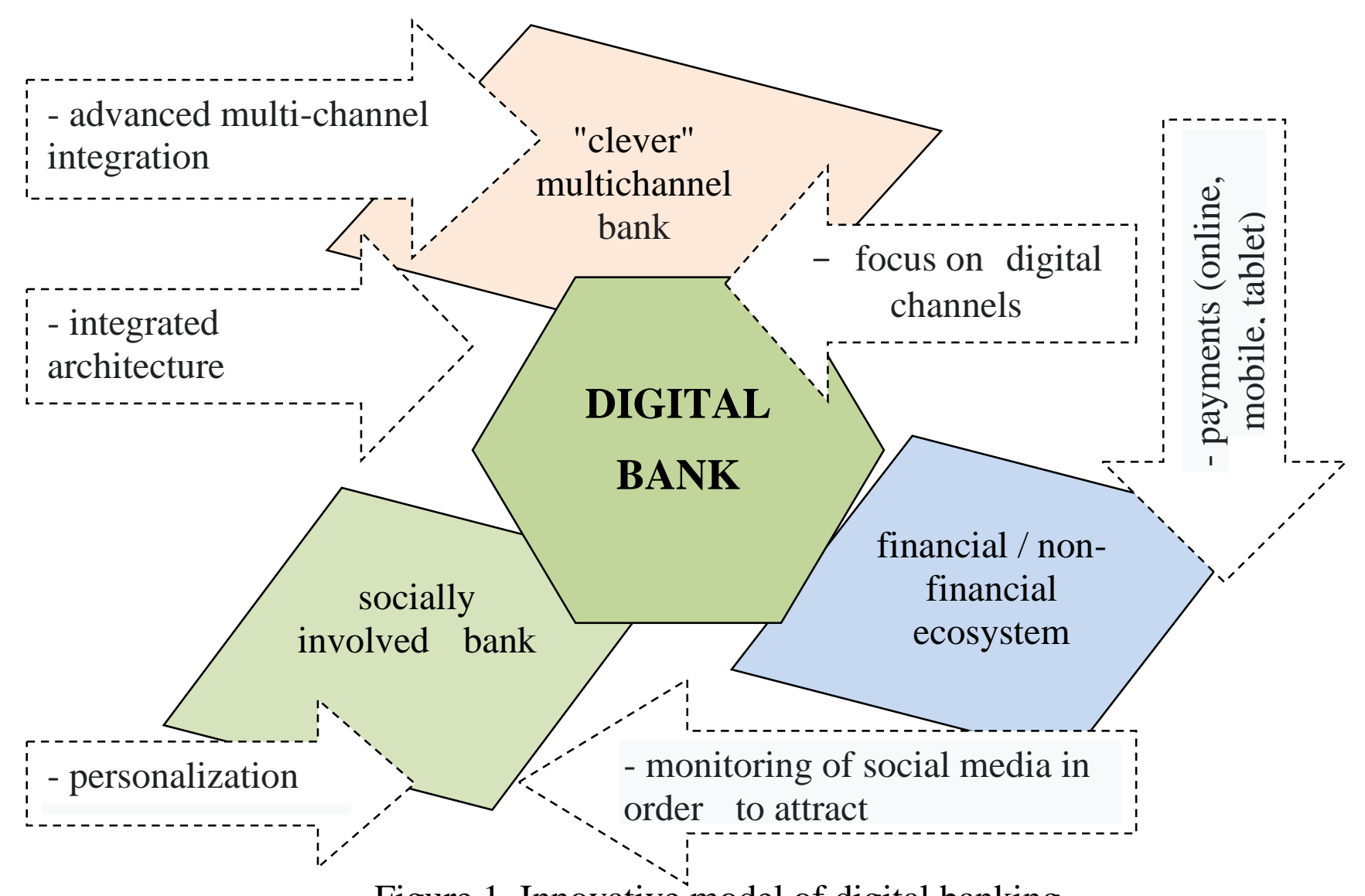

Figure 1. Innovative model of digital banking

Undoubtedly, the use of digital levers in Ukraine will improve and develop the banking business, retain regular and attract new customers, open access to new sources of profit. To do this, banking institutions need to rethink the strategy of their activities to become consultants, suppliers, coordinators, aggregators and providers in the shuffling and provision of banking services.

Thus, digital banking is a new promising concept in the field of electronic banking, which aims to enrich standard online and mobile banking, integrate digital technologies using various payment channels, social media, innovative payment solutions. After all, the active introduction of digital banking is the main requirement for the emergent integration of the domestic banking system into the global digital banking system.

The introduction of digital banking in Ukraine should take into account the level of development of various parts of the national economy, the uneven development of which is due to the law of growth of business needs and other laws and contradictions of productive forces, as well as features of production, innovation, component, territorial structure.

When considering the formation of the territorial organization of digital banking should be based on the law of uneven world economic development, or the law of capitalist mode of production, which contains a justification for the importance of taking into account internal links between sustainable development of enterprises, industries, various sectors of the economy and uneven levels of development of individual elements of the system of productive forces and relations of property entities 
within different industries, areas of the economy in the world economy, its individual regions and countries.

To understand the features of the territorial organization of digital banking should analyze the component and territorial structure.

The component structure of the territorial organization of digital banking is a composition, a set of its functional components (types of economic activity, integrations, aggregations), which are serviced by banking institutions in the processes of specialization and complex formation of the region's economy. According to the functional purpose of economic activities in the region are divided into main, basic, related, additional, local and service.

Effective implementation of the component structure involves obtaining external and internal effects. The external effect of the functioning of economic activities is manifested in the territorial specialization of the region, and the internal effect of the economic activities of the region is manifested in the level of its sustainable development.

Territorial structure is the ratio and mutual location of different forms of territorial concentration of human activity; such forms are also called elements of territorial structure (zones, districts, nodes, centers, points, etc). In their content, these elements of the territorial structure can be integrated, intersectoral and sectoral. Elements of territorial structure can be zonal, regional and local: zonal (zone, district) are divided into integrated and specialized, regional - these are those that have state political and administrative boundaries, local represented by nodes, centers, points, agglomerations and more.

According to the compositional feature, the elements of the territorial structure are point, linear and nodal formations. The corresponding type of territorial structure of banking service is formed regionally (radial-circular, rectangular-regular, linearnodal, multicore, etc).

Thus, the territorial organization of digital banking is a system of territorial and virtual banking services of functioning structures of productive forces in order to ensure their expanded reproduction in specific geospatial-temporal coordinates.

\section{References:}

1. Klein's O. Preface for «Digital Banking». URL : http://www.oklein.fr/banque/foreword-olivier-klein-digital-banking/.

2. Skinner K. (2014) Digital Bank. How to create a digital bank or become one. P.320.

3. Cross N. What's Your Definition of «Digital» in Banking? URL : $\mathrm{http} / / /$ thefinancialbrand.com/41151/defining-digital-in-banking-nextbank-facebook/.

4. Bales S. (2014) Mobile Ready: Connecting With The Untethered Consumer. P.126.

5. A Critical Balancing Act : US Retail Banking in the Digital Era (2013). P.15. 


\title{
ФОРМУВАННЯ ОПТИМАЛЬНОГО ЗАЛИШКУ ГРОШОВИХ КОШТІВ СІЛЬСЬКОГОСПОДАРСЬКИХ ПІДПРИЕМСТВ
}

\author{
Борисова Вікторія Анатоліївна \\ д.е.н., професор кафедри фінансів, банківської справи та страхування \\ Сумський національний аграрний університет \\ Поцелусва Тетяна Сергіївна \\ магістрант \\ Сумський національний аграрний університет
}

Управління грошовими коштами або залишком грошових коштів, що

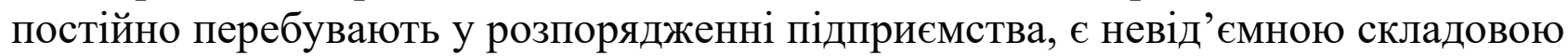
частиною управління активами сільськогосподарського підприємства.

Об'єктами управління виступають грошові кошти в касі, на поточних рахунках, у дорозі та їх еквіваленти. Мета управління грошовими коштами сільськогосподарського підприємства - визначення оптимального залишку грошових коштів, який необхідний для розрахунку за своїми невідкладними поточними і фінансовими зобов'язаннями, а також визначення інвестиційних можливостей підприємства здійснювати короткострокові фінансові вкладення.

У сучасній науковій літературі виділяють декілька моделей оптимізації залишку грошових коштів, які можуть бути використані i для сільськогосподарських підприємств. Таке, до таких моделей відносять:

1. Модель Баумоля - передбачає наявність постійних та фіксованих грошових потоків: вхідний потік передбачається запланованим та контрольованим, вихідний потік - незапланованим та контрольованим.

2. Модель Міллера-Орра - передбачає наявність певного розміру страхового запасу і певна нерівномірність в надходженні та витрачанні грошових коштів, а відповідно і залишку грошових активів. Мінімальна межа формування залишку грошових активів приймається на рівні страхового залишку, а максимальна - на рівні трикратного розміру страхового залишку. Грунтується на припущені, що притоки та відтоки будуть здійснюватися часом одночасно, а іноді притоки будуть більше відтоків. Приймається до уваги можлива невизначеність грошових надходжень та виплат. Модель дає змогу оптимізувати величину грошових коштів, оцінити загальний обсяг грошових коштів, частини, які слід тримати на розрахунковому рахунку та в цінних паперах, обсяг і необхідність здійснення взаємної трансформації грошових коштів та фінансових активів, що швидко реалізуються. В моделі встановлюються дві контрольні точки - нижня межа - мінімально допустимий залишок грошової готівки, верхня межа - сума коштів, втрати від зберігання яких дорівнюють максимально можливим втратам від нестачі ліквідності. Наявність зовнішніх та внутрішніх контрольних лімітів при їх досягненні одразу здійснюються контрольні дії [2]. 
3. Модель Стоуна - грунтується на припущені, що притоки та відтоки будуть здійснюватися часом одночасно, а іноді притоки будуть більше відтоків. В моделі встановлюються дві контрольні точки - нижня межа - мінімально допустимий залишок грошової готівки, верхня межа - сума коштів, втрати від зберігання яких дорівнюють максимально можливим втратам від нестачі ліквідності. Наявність зовнішніх та внутрішніх контрольних лімітів - при їх досягненні не одразу здійснюються контрольні дії.

4. Модель Ю.В. Козиря - вважається пристосованою моделлю Баумоля та Міллера-Орра до національних умов господарювання, вихідними умовами виступає набір змінних гіпотетичної функції ліквідності: серед ринкових котирувань активів, постійні витрати конвертації, ставка процента за цінними паперами, альтернативна ставка процента та час, необхідний для конвертації 3 одного активу в інший.

5. Модель Є.Ю. Крижевської - фактично є перетвореною моделлю МіллераОрра для планування запасу грошових коштів відповідно у періоди високої інфляції, що перевищує ставку доходності за ліквідними фінансовими інструментами, та при відсутності державних гарантій на вкладення в інвестиційні фонди коштів у валюті з метою уникнення знецінювання; в періоди 3 нормальним темпом інфляції підприємствам рекомендовано обирати ті фінансові інструменти, вкладення в які є менш рискованими; підприємства, що мають стабільних грошовий приплив, рекомендовано здійснювати вкладення у валютні депозити [1].

6. Модель Л.Т. Снітко - найбільш проста модель, що передбачає встановлення двох платіжних днів на тиждень, в інші дні - гроші зберігаються на депозиті.

У чистому виді зазначені моделі не можуть бути застосовані до сільськогосподарських підприємств. Подальшим розвитком зазначених моделей $\epsilon$ врахування таких специфічним характеристик сільськогосподарських підприємств, як сезонність економічної діяльності та розмір підприємства. Зазначені фактори суттєво впливають на якість формування оптимального залишку грошових коштів сільськогосподарських підприємств.

\section{Список літератури}

1. Завора Т.М. Теоретичні основи аналізу та оптимізації грошових потоків підприємства. Економіка і регіон. № 4 (47). 2014.С. 74-79.

2. Піскунова Н.О. Пошук оптимальної моделі управління грошовими потоками. Ефективна економіка № 2. 2017. URL: http://www.economy.nayka.com.ua/?op=1\&z=5454 (дата звернення 09.03.2021). 


\title{
СИСТЕМА УПРАВЛІННЯ ЛОГІСТИЧНИМИ РИЗИКАМИ ПІДПРИЕМСТВА
}

\author{
Борисова Вікторія Анатоліївна \\ д.е.н., професор кафедри фінансів, банківської справи та страхування \\ Сумський національний аграрний університет \\ Козленко Владислав Русланович \\ магістрант \\ Сумський національний аграрний університет
}

Логістична діяльність $є$ невід'ємною складовою розвитку будь-якого сучасного підприємства чи установи. Проте, як і будь-яка діяльність, логістична залежить від впливу ризиків, що можуть звести нанівець позитивний ефект. Тому побудова системи управління логістичними ризиками надзвичайно важлива в сучасних умовах.

Розглянемо основні чинники логістичного ризику, як передумова побудови ефективної системи управління. Ми погоджуємось з Вітлінським В.В. та Глушко B.В., що чинники мають як макроекономічний так і мікроекономічних характер, тобто залежать від самого підприємства.

Так, до основних з них слід віднести:

- відсутність фахівців, які виконуватимуть необхідні логістичні функції;

- значна плинність кадрів необхідної кваліфікації;

- відсутність достатнього матеріального, фінансового та інформаційного та організаційного забезпечення для виконання необхідних функцій;

- недостатній досвід виконання логістичних функцій;

- низька якість виконання логістичних функцій;

- занадто великі витрати на виконання логістичних функцій;

- передача у аутсорсинг основних логістичних функцій підприємства;

- нечітке формулювання вимог до постачальника послуг;

- залежність підприємства від одного постачальника логістичних послуг;

- відсутність економії витрат при застосуванні логістичних послуг;

- неможливість забезпечення гнучкості реагування на зміни у логістичній діяльності підприємства;

- неможливість економії коштів порівняно з іншими постачальниками;

- неможливість відзначитися на ринку збуту особливою логістичною якістю серед конкурентів;

- втрата прямих зв'язків з клієнтами підприємства;

- недостатня обізнаність фахівців зі специфікою діяльності підприємства;

- ускладнення втручання у процес виконання логістичних функцій з боку замовника;

- фактичне роз'єднання логістичного процесу на підприємстві;

- несвоєчасне, неякісне або неповне надання логістичних послуг;

- можливість витоку конфіденційної інформації; 
- несформована законодавча база й відсутність важелів державного логістичного регулювання в Україні;

- зростання психологічної напруженості серед персоналу підприємства, виникнення конфліктів;

- несвоєчасне або неповне реагування на виникнення несприятливих відхилень від очікуваних значень параметрів логістичного управління;

- дефіцит коштів на здійснення коригуючих заходів $[1,2]$.

Побудова системи управління ризиками в логістичній діяльності підприємств передбачає проходження декількох послідовних етапів.

На першому з них передбачається виявлення потенційних внутрішніх (управлінських) і зовнішніх (економіко-політичних) ризиків. Далі потрібно визначити рівень небезпеки, що несуть виявлені ризики.

Тобто на другому етапі здійснюється їх оцінка у кількісному вимірі 3 використанням статистичних, математичних, експертних та інших методів оцінки. Кількісна оцінка дозволяє отримати чисельне значення ризиків логістичної системи підприємства, ймовірностей їх настання та наслідків.

Наступний етап передбачає аналіз впливу факторів ризику на його результат та аналіз впливу величини та частоти ризику на показники логістичної діяльності, що здійснюються 3 використанням методів кореляційного, регресійного аналізу, імітаційного моделювання та аналітичних методів [3].

На п’ятому етапі визначаються конкретні методи, які будуть застосовані для управління ризиком: страхування ризиків, самострахування, диверсифікація ризиків, лімітування логістичних послуг чи взагалі відмова від дій, пов'язаних 3 певним видом ризику. Наступний етап передбачає оцінку ефективності побудованої системи управління логістичними ризиками та внесення змін за потреби.

\section{Список літератури}

1. Вітлінський В. В. Концептуальні засади моделювання та управління логістичним ризиком підприємства. Проблеми економіки. 2013. № 4. С. 246-253.

2. Глушко В. В., Гунченко М.В. Системний аналіз ризиків у логістичній діяльності промислового підприємства. Науковий вісник Міжнародного гуманітарного університету. Серія: Економіка і менеджмент. 2016. Вип. 17. С. 54-58.

3. Мамчин М.М. Вплив логістичних ризиків на підвищення ефективності діяльності підприємств. Вісник Національного університету «Львівська політехніка». 2013. № 720. С. 45-51. 


\title{
СУЧАСНІ ТЕНДЕНЦЇ̈ У ПРОЦЕСІ ПРОФЕСІЙНӦ̈ ПІДГОТОВКИ МАЙБУТНІХ ФАХІВЦІВ ЕКОНОМІЧНОГО ПРОФІЛЮ
}

\author{
Біланич Людмила Віталіївна, \\ кандидат економічних наук, \\ доцент кафедри управління, \\ фінансів та інформаційних технологій \\ Карпатського університету \\ імені Августина Волошина, м. Ужгород
}

\begin{abstract}
Анотація У статті окреслено особливості професійної підготовки майбутніх фахівиів економічного профілю. Визначено структуру, основні складові освітнього прочесу здобувачів освіти, а також напрями його вдосконалення.

Ключові слова: економіка, освітній процес, майбутні фахівиі економічного профілю, інформачійно-комунікаційні технології.

Key words: economics, educational process, future specialists in economics, information and communication technologies.
\end{abstract}

Постановка проблеми. Динамічність соціально-економічних процесів формує потребу в забезпеченні ринку праці фахівцями, здатними швидко переорієнтовуватися в нових умовах, бути готовими брати на себе відповідальність за наслідки своєї роботи. Особливо це стосується фахівців економічного спрямування, які мають не лише оволодіти необхідними професійними навичками, вміти орієнтуватися у змінах нормативно-правової бази, передбачати можливі зміни економічної ситуації як на національному, так i на глобальному рівнях, але й володіти відповідною інформаційнокомунікаційною компетентністю, оскільки економіка є соціальною наукою та функціонує в умовах швидких інформаційних змін [1]. Зокрема, в умовах інноваційного розвитку підприємств економічної галузі виникає необхідність безперервної модернізації змісту професійно-практичної підготовки майбутніх фахівців, що передбачає осучаснення змісту, оновлення навчальних планів, перегляду співвідношення теоретичних і практичних знань відповідно до потреб роботодавців.

Упровадження інформаційно-комунікаційних технологій (IКT) сприяє засвоюванню здобувачами освітніх послуг складних абстрактних теоретичних процесів; орієнтує на сучасне розуміння принципу наочності та забезпечує перетворення студентів 3 пасивних спостерігачів досліджуваних процесів та явищ на активних учасників навчально-пізнавального процесу, який набуває дослідницького та творчого характеру. Крім того, ІКТ створюють передумови для постановки та розв'язання нових дидактичних завдань, які неможливо вирішити традиційним шляхом [1]. 
Зважаючи на викладене вище, переконані, що проблема використання IКТ та інтернет-ресурсів $є$ неабияк актуальною, а отже, потребує подальшого дослідження.

Аналіз наукових досліджень, науково-педагогічної літератури, а також напрацювань із галузі знань «Економіка» засвідчує, що засади професійної підготовки майбутніх фахівців-економістів з урахуванням сучасних тенденцій розвитку вітчизняної економічної галузі вивчалися за такими напрямами: професійне навчання бакалаврів у фінансово-економічних коледжах (К. Беркита); формування ділової культури студентів бізнес-коледжу (А. Вишневська); формування економічної компетентності студентів закладів вищої освіти (Н. Волкова); індивідуальний підхід до формування у майбутніх економістів професійної компетентності (Л. Дибкова); інформаційна культура майбутнього економіста (М. Коляда); застосування кредитно-модульної системи навчання студентів-економістів (І. Мороз); психолого-педагогічна підготовка майбутніх економістів (Т. Поясок); компетентнісні моделі освіти бакалаврів i магістрів напряму «Економіка і підприємництво» (С. Степаненко); застосування інформаційно-комунікаційних технологій у підготовці майбутніх економістів (Р. Манн); уміння використовувати ІКТ на практиці 3 метою вирішення суспільних та професійних завдань (О. Овчарук) та інші.

Мета статті - дослідити сучасні тенденції, зокрема особливості використання IКТ та інтернет-ресурсів, у професійній підготовці майбутніх фахівців економічного профілю.

Виклад основного матеріалу. Професійна підготовка майбутніх економістів - це процес формування професійних знань, практичних умінь і навичок студентів, мотивації до навчання і самовдосконалення та вміння самостійно організовувати навчальний процес. Така підготовка повинна відбуватися 3 урахуванням набутого досвіду, 3 використанням ефективних сучасних інноваційних технологій, а ії підгрунтям повинні бути оновлення змісту, форм організації навчально-виховного процесу відповідно до світових стандартів [2, с. 87].

Відповідно виникає необхідність покращення рівня економічної освіти студентів. Учені пропонують реформувати систему вищої економічної освіти за такими напрямами: необхідність застосування інноваційних педагогічних технологій; урахування поліфункціональних міжпредметних зв'язків; посилення ролі самостійної роботи в освітньому процесі; налагодження механізмів взаємодії освітян та представників ринку праці та роботодавців; наближення здобутих результатів наукових досліджень студентів та професорськовикладацького складу до їх практичного використання в реальних умовах [3].

В умовах швидкої інформатизації суспільних процесів та розвитку інформаційних технологій важливого значення набуває проблема використання засобів ІКТ у підготовці фахівців економічного спрямування, а також формування та розвиток компетентностей майбутнього економіста щодо оволодіння означеними технологіями, адже, як відомо, їхній неперервний i швидкий розвиток із кожним роком змінює процес отримання, аналізу, 
опрацювання та презентації нової інформації, необхідної для навчального процесу та професійного розвитку [4, с. 29].

Зважаючи на це, у підготовці майбутніх економістів доцільно використовувати IКТ за такими основними напрямами:

навчанням (наприклад, Moodle); гаджети для унаочнення навчального матеріалу (мультимедійні комплекси); засоби підтримки самостійної та проєктної роботи (персональні настільні і портативні комп'ютери, мережні застосунки, прикладне програмне забезпечення тощо);

як об’єкт вивчення: для ознайомлення зі структурою, особливістю функціонування цифрової техніки; для вивчення спеціалізованого програмного забезпечення професійного спрямування (при вивченні профільних дисциплін) та ін.

Відповідно як засіб підтримки освітнього процесу ІКТ можна й доцільно використовувати на всіх його етапах, зокрема у: викладі та роз'ясненні нової інформації; актуалізації здобутих знань, повторенні, узагальненні, закріпленні вивченого матеріалу; виконанні навчальних завдань (розв’язанні професійних задач, підготовці проєктів тощо); самостійній і позааудиторній роботі; контролі та самоконтролі навчальних досягнень; самоосвіті, дистанційній, інформальній освіті та ін. [5].

Сьогодні процес індивідуалізації навчальної діяльності студентів під час пандемії короновірусу COVID-19 уже неможливо уявити без використання інтернет-ресурсів, які надають необмежений доступ до оволодіння новими знаннями, вміннями та навичками як в аудиторній, так i самостійній, індивідуальній роботі, розширюють інноваційні освітні можливості, наближують українську вищу освіту до європейських вимог та потреб інформаційного суспільства.

Так, для забезпечення належного рівня інформаційної та навчальнометодичної підтримки студентів-економістів у суб'єктів освітнього процесу в закладі вищої освіти необхідно запровадити систему заходів, серед яких: підтримка порталу дистанційного навчання, наприклад, на базі LMS Moodle; підтримка електронної бібліотеки 3 можливістю доступу до різноманітної літератури; підтримка корпоративної пошти з високим ступенем надійності та безпеки; підтримка електронного репозитарію 3ВО, що містить результати науково-дослідних робіт, публікацій науковців, викладачів, аспірантів, студентів закладу, для їхнього централізованого зберігання та надання у відкритий онлайндоступ світовій академічній спільноті; забезпечення суб'єктам освітнього процесу необмеженого доступу до мережі Інтернет та ін. [5].

Зважаючи на викладене вище, використання IKT та інтернет-ресурсів у навчальному процесі сприяє:

- розвитку творчого потенціалу студентів; розвитку їхніх комунікативних здібностей;

- розвитку вмінь експериментально-дослідницької діяльності;

- підвищенню ефективності та якості навчання [6]. 
Однак варто зауважити, що в процесі підготовки майбутніх фахівців економічного спрямування деякі питання потребують вдосконалення, як-от: більш активне залучення до освітнього процесу роботодавців, зокрема проведення «круглих столів», тренінгів для студентів на базі підприємств; залучення студентів до вирішення наявних на підприємствах проблем (участь у проєктних групах, написання бізнес-планів, складання кошторисів тощо) 3 перспективою подальшого працевлаштування; формування необхідної матеріально-технічної бази закладів освіти та підвищення кваліфікації професорсько-викладацького складу щодо застосування сучасних засобів IКТ у підготовці майбутніх фахівців економічного профілю.

Висновки. Ефективність підготовки майбутніх фахівців-економістів неможлива без удосконалення та прогнозування ефективності навчального процесу. Тому першим кроком до вирішення даної проблеми, на нашу думку, має бути корекція мети, чітка структуризація змісту та науково-методичне обгрунтування кожної 3 навчальних дисциплін, які забезпечують освітню підготовку студентів відповідно до вимог сучасної освіти, а саме: розробка нових форм i методів навчання, критеріїв оцінювання професійної майстерності здобувачів освіти, обгрунтування теоретичних і методичних основ управління процесом навчання в цілому.

Подальші наші дослідження плануємо спрямувати на розробку методики щодо навчання майбутніх фахівців економічної галузі в умовах дистанційного навчання.

\section{СПИСОК ЛІТЕРАТУРИ}

1. Манн Р. Деякі аспекти застосування інформаційно-комунікаційних технологій у підготовці майбутніх економістів. Інформаційні технології і засоби навчання. 2018.2 T. 64.2 № $2 . \quad$ URL: https://www.researchgate.net/publication/331405099_DEAKI_ASPEKTI_ZASTOS UVANNA_INFORMACIJNO-

KOMUNIKACIJNIH_TEHNOLOGIJ_U_PIDGOTOVCI_MAJBUTNIH_EKONOM ISTIV (дата звернення: 01.02.2021).

2. Деркач Ю. В. Підготовка майбутніх економістів в умовах нових технологій навчання. Нові технології навчання. 2010. № 61. С. 87-91.

3. Гайдученко Ю. Особливості підготовки майбутніх економістів у вищих навчальних закладах. Paradigm of knowledge. 2017. № 3 (23). URL: http://oaji.net/articles/2017/1739-1499797540.pdf (дата звернення: 08.01.2021).

4. Синиця М. О. Використання мультимедійних технологій у навчальному процесі ВНЗ як засіб формування педагогічних знань. Житомир : Вид-во ЖДУ ім. І. Франка, 2017. С. 418-438.

5. Прийдак Т., Яловега Л., Лега О. та ін. Розвиток цифрової компетентності як умова забезпечення конкурентоспроможності майбутніх економістів. Інформаційні технології і засоби навчання. 2019. Т. 73. № 5. C. 33. URL: https://www.researchgate.net/publication/336951373_ROZVITOK_CIFROVOI_KO MPETENTNOSTI_AK_UMOVA_ZABEZPECENNA_KONKURENTOSPROMOZ NOSTI_MAJBUTNIH_EKONOMISTIV (дата звернення: 01.02.2021). 
6. Акуленко К. Підготовка майбутніх економістів з використанням засобів інформаційних технологій. URL: http://ki.lutsk-ntu.com.ua/node/113/section/2 (дата звернення: 16.12.2021). 


\title{
РОЗРОБКА СТРАТЕГІЧНИХ НАПРЯМКІВ РОЗВИТКУ ВЗАЕМОВЦДНОСИН В СИСТЕМІ «ВЛАДА- БІЗНЕС-ГРОМАДА»
}

\author{
Геснко Михайло Миколайович \\ к.е.н., доцент, завідувач кафедри фінансів, банківської справи та \\ страхування \\ Сумський національний аграрний університет \\ Завальний Микола Васильович \\ магістрант \\ Сумський національний аграрний університет
}

Стратегічний план розвитку компанії необхідний абсолютно будь-якому суб'єкту господарювання, у тому числі і об'єднаним територіальним громадам, адже без нього суб'єкт господарювання здатен існувати тільки до певного моменту і не зможе рости і розвиватися послідовно.

Стратегія є потужним інструментом об'єднання лідерів бізнесу, посадовців місцевої влади, пересічних громадян для створення публічно-приватного партнерства, що має позитивний вплив на місцевий діловий клімат та конкурентне становище громади, а також на вирішення інших питань, пов'язаних з рівнем життя всіх громадян.

Стратегія підкреслює конкурентні переваги території громади на підставі існуючих природних, матеріальних, фінансових, економічних, трудових, соціальних, інтелектуальних ресурсів, які при належній організації та об'єднанні зусиль, можна використовувати для вирішення нагальних проблем місцевого економічного розвитку. Тому стратегія розвитку об'єднаної територіальної громади зосереджена на напрямах, які наддадуть економічному розвитку території найбільші шанси в майбутньому. Економічний розвиток передбачає формування сприятливого бізнес-середовища і створення умов для інвестування на тривалий період, що сприятиме економічному зростанню і поліпшенню якості життя громади в тріаді «влада-бізнес-громада».

Питання залучення інвестицій, розвитку місцевих підприємств, розвитку інфраструктури і забезпечення гідної якості життя взаємопов'язані, тому успішна робота над ними можлива лише за умови сприйняття їх як цілісної системи. Поліпшення в одному 3 питань сприятиме поліпшенню в інших. Стратегія пов'язана 3 іншими документами стратегічного характеру, місцевими та регіональними програмами, які вже ухвалені і виконуються відповідними органами [1].

Послідовність дій, при розробці стратегічних напрямків розвитку громади, представлено на рисунку 1. 
1. Організація роботи зі стратегічного планування розвитку

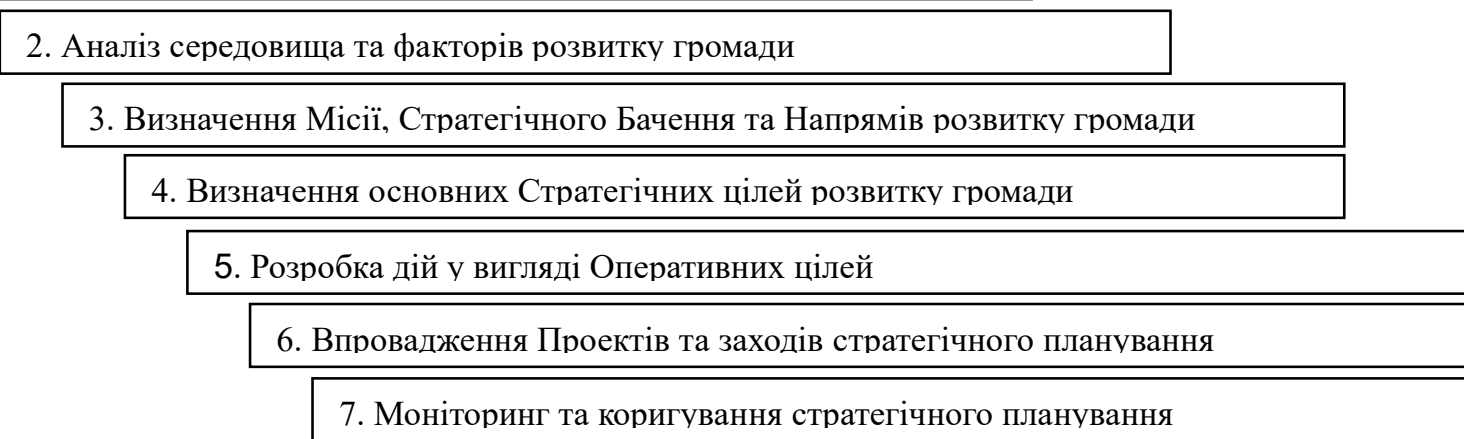

Рисунок 1. Послідовність дій при визначенні стратегічних напрямків розвитку об'єднаних територіальних громад

Адаптація визначених етапів в контексті розробки стратегічних напрямків розвитку взаємовідносин в системі «влада-бізнес-громада» для конкретної громади передбачає:

- визначення з пріоритетними напрямами видів економічної діяльності;

- розробку детальної процедуру купівлі/продажу комунального майна чи його оренди;

- визначення та оприлюднення переліку владних послуг i можливих преференцій для інвесторів;

- визначення території пріоритетного інвестиційного розвитку громади та їхню спеціалізацію;

- розробку інвестиційних пропозицій, розміщення їх на сайті селищної ради (українською та англійською мовами);

- щонайменше раз на рік брати участь в інвестиційній виставці за межами громади.

Мотивування та сприяння розвитку бізнесу та запровадження інновацій на теренах громади можуть додатково сприяти пільгові режими користування землею та пільги по місцевих податків і зборів для нових підприємств, спрощення процедури реєстрації бізнесу на території громади, селищна рада забезпечить підведення комунікацій, інших складових інфраструктури, необхідних для започаткування та ведення бізнесу, до визначених потенційних інвестиційних об`єктів

\section{Список літератури}

1. Стратегія розвитку Михайло-Коцюбинської селищної ради Об'єднаної територіальної громади 2018-2027 роки. URL: https://rada.info/upload/users_files/04412509/c2e45575e5eca6f0f163db36b929bbec. pdf (дата звернення 05.03.2021) 


\section{АКТУАЛЬНІ ПРОБЛЕМИ ФУНКЦІОНУВАННЯ ТРАНСПОРТНОЇ ІНФРАСТРУКТУРИ В ЕСТОНІЇ}

\section{Трушкіна Наталія Валеріївна}

К.е.Н.

Інститут економіки промисловості НАН України (м. Київ)

Перспективним напрямом національної економіки Естонії визнано модернізацію транспортної інфраструктури, яка має стратегічне значення у забезпеченні сталого розвитку країни. Для цього є об'єктивні передумови. Естонія має вигідне економіко-географічне й транзитне положення.

У країні функціонує розвинута мережа транспортної інфраструктури, до якої входить автомобільний, залізничний, повітряний, водний (морський, річковий $і$ озерний на Чудському і Псковському озерах), трубопровідний транспорт, а також громадський транспорт пасажирських перевезень.

Географічне положення Естонії дозволяє контролювати транспортні шляхи між країнами Північної Європи; морські магістралі на Балтиці, підходи до портів Фінляндії та Росії у Фінській затоці. У країні діє 18 аеропортів. Талліннський аеропорт імені Леннарта Мері є найбільшим аеропортом Естонії.

В Естонії 45 морських портів і річкових пристаней занесено до Державного реєстру. Усі морські порти розташовані на узбережжі Балтійського моря. Головні морські порти країни: Куйвасту, Кунда, Мууга (поблизу Таллінна), Пярну, Сілламяе, Таллінн (кілька портів).

Bсе це дозволяє забезпечити оптимізацію руху транспортних потоків, раціональну організацію процесів логістичної діяльності [1-10], а також посилити конкурентні позиції на прибалтійському та європейському ринках транспортно-логістичних послуг.

Слід зазначити, що відповідно до досліджень Світового банку [11] за 20122018 рр. індекс ефективності логістики в Естонії не змінився. Так, у світовому рейтингу Естонія посіла в 2018 р. 36-е місце серед 160 країн світу. У 2012 р. країна була на 36-му місці серед 167 країн світу. При цьому за період 20122018 рр. спостерігається тенденція поліпшення позицій Естонії в рейтингу за основними індикаторами, а саме: ранг індикатора «Відстеження постачань» піднявся на 3 позиції; «Своєчасність постачань» - на 3 ; «Простота організації міжнародних вантажоперевезень» - на 2; «Якість логістики та компетентність» - на 2 позиції. Однак ранг індикатора «Якість інфраструктури» знизився на 1 позицію. Ранг індикатора «Ефективність роботи митниці» залишився без змін на 28 позиції (табл. 1). 
Таблиия 1

Оцінка Естонії в рейтингу ефективності логістики за 2012-2018 рр.

\begin{tabular}{|l|c|c|c|c|}
\hline \multirow{2}{*}{ Індикатори } & \multicolumn{4}{c|}{ Роки } \\
\cline { 2 - 5 } & \multicolumn{2}{c|}{2012} & \multicolumn{2}{c|}{2018} \\
\cline { 2 - 5 } & Ранг & Бали & Ранг & Бали \\
\hline Якість інфраструктури & 43 & 3,13 & 44 & 3,10 \\
\hline Простота організації міжнародних вантажоперевезень & 41 & 3,19 & 39 & 3,26 \\
\hline Ефективність роботи митниці & 28 & 3,30 & 28 & 3,32 \\
\hline Якість логістики та компетентність & 42 & 3,15 & 40 & 3,15 \\
\hline Відстежування постачань & 46 & 3,20 & 43 & 3,21 \\
\hline Свосчасність постачань & 33 & 3,80 & 30 & 3,80 \\
\hline Індекс ефективності логістики & 36 & 3,30 & 36 & 3,31 \\
\hline
\end{tabular}

Складено за даними: [11].

Як показує статистичний аналіз, обсяги вантажоперевезень залізничним транспортом скоротилися за 2000-2018 рр. на 56,4\%. Обсяги перевезення вантажів автомобільним транспортом, навпаки, збільшилися на 11,7\%. Аналогічна ситуація спостерігається і 3 показником вантажообігу. Так, вантажообіг залізничного транспорту зменшився на 68\%, автомобільного, відповідно, зріс на 20\% (табл. 2).

Таблиия 2

Динаміка обсягів перевезень вантажів і вантажообіг за видами транспорту

\begin{tabular}{|l|c|c|c|c|}
\hline Роки & \multicolumn{2}{|c|}{ Вантажоперевезення, тис. $m$} & \multicolumn{2}{c|}{ Вантажоббі, млн ткм } \\
\hline & залізничний & автомобільний & залізничний & автомобільний \\
\hline 2000 & 63861 & 25514 & 8102 & 4820 \\
\hline 2005 & 68187 & 29867 & 10639 & 5821 \\
\hline 2010 & 46705 & 27315 & 6638 & 5614 \\
\hline 2013 & 43682 & 31080 & 4722 & 5986 \\
\hline 2014 & 36289 & 27358 & 3256 & 6310 \\
\hline 2015 & 28026 & 28162 & 3117 & 6259 \\
\hline 2016 & 25363 & 34585 & 2340 & 6717 \\
\hline 2017 & 27255 & 28967 & 2325 & 6189 \\
\hline 2018 & 27824 & 28493 & 2595 & 5783 \\
\hline
\end{tabular}

Представлена наявна інформація із статистичної бази даних Свропейської економічної комісї ООН.

Складено за даними: [12, с. 144-145, 147-149; 13, с. 104, 107, 108, 110$].$

Транзит вантажів є традиційно важливим напрямом для Естонії. Але обсяги товаропотоку і перевезення сировини зі східного напрямку знижуються вже кілька років поспіль, Незважаючи на те, що Китай, Російська Федерація і і Західна Європа сформували достатньо ефективну логістичну систему, яка навіть при стресових ситуаціях у світовій економіці показує позитивну динаміку розвитку, транзитні потоки в Естонії суттєво скоротилися. Хоча Прибалтика зробила значний внесок у розвиток мультимодальних перевезень Калінінграда й однойменної області РФ, складна політична ситуація між країнами призвела до того, що російські порти, залізничні комунікації і транспортні вузли на заході Росії стали розвиватися стрімкими темпами, щоб не залежати від транзиту через країни Балтії. 
Якщо говорити про вантажопотік у північному напрямку, то ситуація в Естонії також складна. Одна з провідних транспортних компаній країни, Tallink Grupp AS, заявила, що обсяг вантажоперевезень між Естонією і Фінляндією скоротився у 2020 р. на 9,5\%.

Варто відмітити, що на функціонування транспортної інфраструктури Естонії негативно вплинула i коронавірусна пандемія COVID-19. Тому адміністрація порту Таллінн впровадила захід з метою стимулювання торгівлі у нинішній кризовій ситуації. Його суть полягає у звільненні від сплати канального збору суден, що заходять в естонські порти, починаючи з 1 квітня 2020 р. і до 31 березня $2021 \mathrm{p}$.

Отже, ситуація в Естонії з позицій ефективності транспортної логістики та ланцюгів постачань вимагає фундаментальних змін. У зв'язку з цим у країні заплановано провести масштабну модернізацію залізничної інфраструктури [14]. Естонська залізниця (Eesti Raudtee, EVR) планує реалізувати інвестиційний проект, який передбачає істотну реконструкцію інфраструктури до 2030 року. Зокрема, до 2024 року належить модернізувати системи забезпечення безпеки руху на шести лініях і оновити близько 50 станцій. Вартість проекту розвитку засобів безпеки та управління рухом поїздів становить понад 115 млн євро. Контракт на виконання цих робіт EVR підписала 3 консорціумом у складі Siemens Mobility і фінської компанії GRK Rail. Модернізація систем залізничної автоматики і телемеханіки відкриє можливість оснащення EVR у майбутньому сучасними європейськими засобами управління рухом поїздів, зокрема ERTMS / ETCS. Угода відноситься до двох перших етапах проекту. Перехід на систему ERTMS / ETCS стане предметом третього етапу.

При цьому Європейський інвестиційний банк оголосив про підписання 3 Естонської залізницею (Eesti Raudtee) кредитної угоди в розмірі 95 млн євро терміном на 25 років [15]. Кошти призначено для модернізації колії, систем сигналізації та диспетчерського управління на більшій частині залізничної мережі країни, а також для цифровізації систем управління рухом поїздів. Приймаючи рішення про кредитування, ЄІБ наголошує на необхідності скорочення шкідливих викидів від автомобільного транспорту та стимулювання переходу пасажирів на залізничний вид транспорту. Завдяки модернізації інфраструктури Eesti Raudtee підвищиться швидкість і безпеку руху поїздів.

План робіт передбачає капітальний ремонт ділянок лінії Таллінн-Тарту, у тому числі будівництво нового моста через річку Емайигі. Відремонтований шлях і оснащення переїздів шлагбаумами дозволять збільшити швидкість руху поїздів до 135 км/год і тим самим скоротити час поїздок. На лінії Тапа-Нарва заплановано капітальний ремонт двох мостів та оновлення 54 км шляху. Усі модернізовані лінії входять до ділянки Північне море - Балтика транс'європейського коридору TEN-T.

Виходячи з вищевикладеного, можна дійти такого висновку. На даний час 3 метою вирішення актуальних проблем функціонування транспортної інфраструктури в Естонії та виходу з кризових ситуацій доцільно вносити зміни й доповнення до Стратегічного плану розвитку транспорту до 2030 року. Цей 
програмний документ має стати інструментом антикризового менеджменту в сфері транспорту й логістики і визначати на національному рівні бачення, яке зосереджується, у першу чергу, на:

якісній, доступній та інтегрованій транспортній інфраструктурі, що сприяє соціальній інтеграції, поєднуючи менш розвинені регіони 3 чудовою інфраструктурою, та забезпечує міжнародну конкурентоспроможність Естонії, використовуючи іiі географічний потенціал як транзитної країни;

конкурентоспроможні транспортні послуги, що сприяють економічному зростанню, оптимальному використанню транспортних мереж, збалансованому розвитку різних транспортних послуг з використанням логістичного підходу та прискоренню інтеграції різних видів транспорту на національному, прибалтійському та європейському рівнях.

Розвиток інтегрованої транспортно-логістичної системи 3 використанням принципів мультимодальності в Естонії, яка б відповідала сучасним вимогам глобальної економіки, сприяє підвищенню рівня конкурентоспроможності, залученню додаткових інвестицій у транспортну сферу, зростанню обсягів міжнародних перевезень за рахунок довгострокового сталого партнерства між учасниками ринку транспортно-логістичних послуг.

У подальших дослідженнях планується надати пропозиції щодо можливості застосування прибалтійського досвіду розвитку транспортної логістики у сучасних умовах національної економіки України.

\section{Список літератури:}

1. Trushkina N. Improving the efficiency of the transport and logistics system in the context of sustainable development: the EU experience [Підвищення ефективності функціонування транспортно-логістичної системи в контексті сталого розвитку: досвід СC]. Territories' development: social, economic and humanitarian issues: monograph / Edited by T. Nestorenko, S. Sliwa; The Academy of Management and Administration in Opole. Opole: Publishing House WSZiA, 2019. P. 142-149.

2. Trushkina N., Rynkevych N. Optimization of information flows in transport logistics [Оптимизация информационных потоков в транспортной логистике]. Contemporary issues of sustainable development: monograph / Edited by T. Pokusa, O. Nestorenko. Opole: The Academy of Management and Administration in Opole, 2019. P. 137-146.

3. Trushkina N. Features of sustainable development of the transport and logistics system in Ukraine [Особливості сталого розвитку транспортно-логістичної системи в Україні]. Mechanisms for Ensuring Sustainable Development of Society: monograph / Edited by T. Nestorenko, A. Ostenda; Katowice School of Technology. Katowice: Wydawnictwo WST w Katowicach, 2019. P. 128-139.

4. Trushkina N. Financial ensuring mechanism of management innovative development of the transport-logistics system. Organizational-economic mechanism of management innovative development of economic entities: collective monograph / Edited by M. Bezpartochnyi, in 3 Vol. / Higher School of Social and Economic. Przeworsk: WSSG, 2019. Vol. 3. P. 227-236.

5. Трушкина Н.В. Современное состояние развития транспортной логистики: опыт Литвы. III International Scientific Conference Modern Transformation in Economics 
and Management: Conference Proceedings (March 29 ${ }^{\text {th }}$, 2019, Klaipeda University, Klaipeda, Lithuania). Riga: Baltija Publishing, 2019. Part I. P. 43-47.

6. Trushkina N. Topical issues of investing in the development of transport infrastructure: experience Australia [Актуальные вопросы инвестирования в развитие транспортной инфраструктуры: опыт Австралии]. Socio-Economic Prospects: collection of scientific articles (July 26, 2019, University of Melbourne). Dingo Publishing, Melbourne, Australia, 2019. P. 30-33.

7. Trushkina N. Problems and prospects for the development of transport infrastructure: the experience of Portugal [Проблемы и перспективы развития транспортной инфраструктуры: опыт Португалии]. Science, Technology and Innovations: collection of scientific articles (August 30, 2019, Universidade Lusofona Porto). Pegasus Publishing, Lisbon, Portugal, 2019. P. 40-44.

8. Trushkina N. European experience in the development an integrated transport and logistics system [Европейский опыт развития интегрированной транспортнологистической системы]. Research and Practice: collection of scientific articles (Paris, September 27, 2019). Lardy Publishing House, Paris, France, 2019. P. 39-43.

9. Трушкіна Н.В. Формування інтегрованої транспортно-логістичної системи в Україні: фінансово-правовий аспект. Emergence of public development: financial and legal aspects: monograph / Yu. Pasichnyk and etc.; Coventry University; The Academy of Economic Science of Ukraine. Agenda Publishing House, Coventry, United Kingdom, 2019. P. 619-629.

10. Трушкіна Н., Шкригун Ю. Актуальні питання розвитку транспортної логістики: досвід Словаччини. Economic and Social-Focused Issues of Modern World: Conference Proceedings of the 3nd International Scientific Conference (November 1718, 2020, Bratislava, Slovak Republic). Bratislava: The School of Economics and Management in Public Administration in Bratislava, 2020. P. 119-124.

11. Connecting to Compete 2018. Trade Logistics in the Global Economy. The Logistics Performance Index and Its Indicators / J.-F. Arvis, 1. Ojala, C. Wiederer, B. Shepherd, A. Raj, K. Dairabayeva, T. Kiiski. Washington, DC, The International Bank for Reconstruction and Development, The World Bank, 2018. 82 p.

12. Транспорт і зв'язок України за 2018 рік: стат. збірник. Київ: Державна служба статистики України, 2019. 154 с.

13. Транспорт України за 2019 рік: стат. збірник. Київ: Державна служба статистики України, 2020. $115 \mathrm{c}$.

14. В Эстонии намерены провести масштабную модернизацию ж/д инфраструктуры. Центр транспортных стратегий. 2020. 3 декабря. URL: https://cfts.org.ua/news/2020/12/03/v_estonii_namereny_provesti_masshtabnuyu_mo dernizatsiyu_zh_d_infrastruktury_62215.

15. Эстония получит от ЕИБ 95 млн евро на модернизацию железных дорог. Центр транспортных стратегий. 2020. 9 июня. URL: https://cfts.org.ua/news/ 2020/06/09/estoniya_poluchit_ot_eib_95_mln_evro_na_modernizatsiyu_zheleznykh_ dorog_59109. 


\title{
АДАПТАЦІЯ ПРОСТОРУ У КРАЇНАХ ЄВРОПИ У КОНТЕКСТІ ВИКЛИКІВ ПАНДЕМІЇ COVID-19
}

\author{
Лабінська Галина Миколаївна \\ кандидат географічних наук, доцент \\ Львівський національний університет імені Івана Франка
}

У контексті викликів пандемії Covid-19, європейські країни активно взаємодіючи і операючись на досвід інших країн світу, змогли змобілізуватися i виробити узгоджені стратегічні вектори розвитку за трьома ключовими позиціями: міждержавна кооперація, A Eropean Green Deal й інтенсифікована діджиталізація усіх сфер життєдіяльності європейського суспільства.

Свропейський комітет 3 питань демократії та врядування (European Committee on Democracy and Governance and COVID - CDDG), сприяючи діалогові і співробітництву на міжурядовому рівні держав-членів Ради Свропи, у часи пандемії скоординував міждержавні зусилля у плані збору й обміну інформацією про правові та політичні розробки, кейси та передовий досвід у відповідь на Covid-19 [1]. Створений Центр експертизи при CDDG підготував новий Інструментарій ReBuS (Resilience Building Strategies), який використовуватиметься органами державної влади при розробках стратегій і реалізації заходів, спрямованих на підвищення стійкості громад.

A Eropean Green Deal ознаменувала переорієнтацію Свропи на сучасну, ресурсоефективну, конкурентоспроможну економіку, де вже до 2050 р. не буде парникових газів; економічне зростання у країнах не матиме прив'язки до використання викопних ресурсів; жодна людина і жодне місце у $Є С$ не залишаться поза увагою [2]. Передбачений чіткий план, який окреслює необхідні інвестиції та інструменти фінансування, яким Європа слідує незважаючи на пандемію. Задля нівелювання просторових відмінностей, які виникнуть у процесі переходу до зеленої економіки, ЄС анонсував фінансову (до €100 млн. на період 2021-2027 pp.) і технічну допомогу регіонам.

Однією з виразних рефлексій першого пандемічного періоду - весна 2020 р., стало навернення уваги до ролі громадських просторів, як це у XIX ст. зробив англійський архітектор і планувальник міста - John Nash, найбільш відомий своїм проектом “Regent's Park” у Лондоні. Новітній проект, започаткований у Франції очільницею Парижа Анн Ідальго - "!5-ти хвилинне місто” відображає дану тенденцію. Суть даної концепції зводиться до того, щоб містяни, виходячи 3 дому, максимум за 15 хвилин змогли б дістатися пішки до роботи, місця надання подібної послуги чи місця відпочинку. За такої просторової організації відпадає потреба у громадському і приватному транспорті, вулиці стають орієнтованими на пішоходів, на широких хідниках з'являється місце для більшої кількості дерев, у затінку яких заклади харчування збільшують кількість літніх 
терас та посадкових місць у них. Мешканці міст, у підсумку, більше перебувають на свіжому повітрі, у публічному просторі, де реально дотримуватися соціальної дистанції, більше переміщуються містом пішки або велосипедом, дбаючи водночас за своє здоров'я.

За роки першої каденції Анн Ідальго у Парижі вдалося побудувати 1400 км велодоріжок, прибрати тисячі паркомісць і закрити для автомобільного руху кілька важливих доріг. У місті створили мапу енергоефективності будинків і вже модернізовано понад 50 тисяч з них. Будівельні норми зробили більш гнучкими, щоб уможливити висадку більшої кількості дерев у подвір'ях будинків у місті. Весною 2020 р., у місті облаштували додатково ще 50 км велодоріжок, які вже назвали “коронавелодоріжками" [3]. У планах мерії - трансформація міста до проведення літніх Олімпійських ігор 2024 р. Насамперед, 3 цього часу у Парижі буде заборонено рух дизельних авто. Басейни, які облаштують вздовж берегів Сени, функціонуватимуть і після завершення Ігор, як громадські локації, а сама очищена ріка стане придатною для купання. На департамент Сена - Сен-Дені, який прилягає до Парижа і є одним з найбідніших регіонів у Франції, очікує будівельний бум: там планують звести екологічне олімпійське містечко i аквапарк, розширять мережу швидкісного електротранспорту. Знаково, що пані мер розірвала спонсорську угоду на $€ 100$ млн. з нафтогазовою компанією Total та взагалі відмовилися від підтримки Олімпійських ігор з боку компаній, які займаються вуглеводневою енергетикою. Звичайно, не усі згідні з політикою Анн Ідальго. Так, до прикладу, тисячі водіїв Uber та приватних сервісів таксі вже влаштовували приватну акцію протесту проти впроваджуваної антиавтомобільної програми муніципалітету.

Анн Ідальго анонсувала також проект перетворення площ коло відомих пам'яток Парижа на “міські ліси” [4]. Зокрема, перед Отель-де-Віль планують посадити хвойні дерева, площу перед Оперою Гарньє перетворити на вишневий сад (зараз тут місце паркування туристичних автобусів). Це змінить звичний архітектурний вигляд Парижа, а новостворені “острівиі свіжості" знизять температуру у місті (адже влітку температури сягають до $+55^{\circ} \mathrm{C}$ ). До 2030 р. міська влада планує засадити рослинністю близько половини міста, озеленюючи паркомісця, облаштовуючи зелені зони у подвір'ях шкіл, на дахах, створюючи нові сквери і парки. Слід зазначити, що подібний проект активно реалізовують на сучасному етапі й у низці міст Китаю.

Багато у чому концепція "15-ти хвилинного міста" корелюється із Барселонським проектом “суперблоків” [5]. Опираючись на проект каталонського будівничого Ildefonc Cerda, міська влада Барселони, впроваджує нову технологію міського простору, задля покращення екології, зниження шумового навантаження і скорочення використання автомобілів на $21 \%$ вже впродовж найближчих двох років. Ідея полягає у наступному: один “суперблок” об'єднує дев'ять кварталів і буде наче окремим районом, куди обмежать в'їзд громадського та приватного транспорту, за винятком велосипедів та міських служб. Перший такий суперблок у місті було апробовано у 1993 р., у 2005 р. ще один. Зараз реалізація проекту супроводжується зміною дорожніх знаків і розмітки, значно меншою тривалістю очікування транспорту; переміщення 
містом у 95\% випадків стало можливим без пересадок. Окрім того, місто отримає до 300 км нових велодоріжок.

Архітектор Осаму Окамура, декан факультету мистецтв та архітектури у Технічному університеті в Ліберці (Чехія), вважає, що у контексті пандемічних викликів міста змінюватимуться у напрямку оптимізації поєднання функцій i безпечного й здорового середовища. Тому, на його думку, пріоритет вибудовуватиметься за пішоходами й велосипедистами; малими крамничками, 3 яких $є$ вихід одразу на вулицю; спокійними зонами міст: внутрішніми подвір'ями будинків і кварталів, зеленими зонами для відпочинку; відкритими дитячими й спортивними майданчиками, спортзалами.

Разом із зміною просторової структури міст архітектор вважає за можливе й зміну проектів житлових будинків (наприклад, будинки 3 великими лоджіями або житловими терасами, які поширені у Франції і Австрії), поверховості забудови (у межах п'яти поверхів), повернення граткових ліфтів. Потреба роботи 3 дому, яка з'явилася під час пандемії, зумовить появу у кожному помешканні певного простору для ділових цілей, у майбутньому це може мати більш масштабне продовження у зміні попиту на ринку офісної нерухомості. В ідеалі О. Окамура бачить пропозицію житла у дружних, безпечних і придатних до життя містах, з яких не хочеться втікати. Котеджі за містом він вважає лише втечею від проблеми, а не їі вирішенням [6].

У місті Турині, в Італії, на занедбаних трамвайних коліях створили оперативно самобутню паркову зону. Новітній парк Преколліна, спроектований урбаністичною ініціативою Torina Stratosferica наприкінці 2020 р., завдовжки 700 м, названий на честь району у якому розташований [7]. Трамвайна лінія, яку побудували у 1980-их рр., припинила свою роботу через помилки у плануванні. Коли місто оновило рухомий склад трамваїв, стало зрозуміло, що нові вагони занадто довгі для старих платформ. Колії стали непридатними для експлуатації через брак місця на кінцевому розвороті. В умовах карантинних обмежень турінці отримали тимчасовий парк, де можна провести час на свіжому повітрі. Сама природа посприяла цьому: колії природним шляхом заросли деревами та дикою травою, залишилося додати незначні деталі: ящики з квітами та лавки. Облаштування паркової зони коштувало місту $€ 18000$.

Пандемія Covid-19 стимулює цифровізацію суспільства. Вже зараз аналітики підсумували, що 2030 рік розпочався у 2020 р. і пандемія зіграла роль каталізатора пришвидшеної діджиталізації [8]. Так, до прикладу, компанія Telexistence 3 вересня 2020 р. випробовує роботів Model-T, призначення котрих регулярно поповнювати товарами полиці японських магазинів. Роботоммерчендайзером можна керувати, одягнувши окуляри віртуальної реальності та рукавички. Японська влада запевняє, що до 2050 р. країна стане лідером у світі за кількістю роботів, якими управляють люди [9]. У Нідерландах, у місті Ренессе, клієнтів китайського ресторану Royal Palace з червня 2020 р. вже обслуговують роботи-офіціанти, зустрічаючи відвідувачів, подаючи замовлення, прибираючи посуд. Знаково, що власник закладу замовив роботів ще до початку пандемії, восени 2019 р., запланувавши модернізацію бізнесу. Тепер таке нововведення актуальне як ніколи [10]. 3 літа 2020 р. два зразки роботів, здатних знищити 
Covid-19 і інші мікроорганізми у приміщенні, вже працювали у медустановах Бахрейну [11]. Роботи за допомогою ультрафіолетового випромінювання упродовж 30 хвилин знищують до 90\% всіх мікроорганізмів у приміщенні. Вони здатні розмовляти на 12 мовах, вимірюють температуру тіла, реагують на голосові команди і використовують технологію розпізнавання осіб. Подібні пристрої, використовувані для обробки поверхонь, принцип дії яких грунтується на використанні ультрафіолету, випущені також у США, Китаї та Данії. Поляки придумали технологію мобільних кас самообслуговування, яка під маркою SmartCart вже запроваджується у мережах Ikea, Carrefour, Spotem [12]. Startub ZeroQs виготовляє візки, оснащені технологією, яка за допомогою встановленого сканера штрих-коду, камери і датчика ваги автоматично ідентифікує продукти, які кладуть у кошик, а завдяки персоналізованому додатку аналізує і завершує покупку, виключаючи таким чином потребу стояти у черзі до каси. Подібна технологія вже запроваджена й у супермаркетах США.

Своєрідною візуалізацією майбутнього став проведений тиждень дизайну "The Shape of Things to Come", Дубаї 2020. Рішення архітекторів, виявилися цілковито орієнтованими на соціальну дистанцію, поділ людей на малі групи і індивідуалізований відпочинок, що відповідає запитові часу. Проекти адаптації вулиць до швидкого і комфортного пересування велосипедів, електросамокатів та пішоходів; новітні варіанти публічних просторів: проект Tarig Khayyat Design Partners пропонує впровадження електронної підлоги, яка зміною забарвлення навколо відвідувача реагуватиме на дотримання соціальної дистанції; варіант безпечного перебування в кафе, через використання спеціальних бульбашок або капсул для відвідувачів; новітній проект нічного клубу “Evolve" студії Rabih Geha Arcitects з Бейруту - завдяки концентричному плануванню приміщення люди дістають змогу розважатися і водночас зберігати соціальну дистанцію; а також проект готелю, організованого з великих кабін - автономних капсул [13].

Прискорення цифрової революції має прояв у переході роботи більшості світових корпорацій на дистанційну форму роботи. Міжнародні зустрічі проводять онлайн. Студенти навчаються дистанційно. Цифрові платежі все інтенсивніше витісняють готівку (у 2020 р. Україна увійшла до топ-10 країн 3 найбільшим зростанням $e$-прибутку) [14]. Але хоча технології ніколи не мали такого великого впливу на наше життя, існує значний ризик того, що він буде поширюватися нерівномірно.

Цифрові технології можуть допомогти швидше покінчити із глобальною бідністю і голодом, у тому числі у сільськогосподарських районах країн, що розвиваються, де більшість людей заробляють собі на життя саме у сільському господарстві. При правильних інвестиціях на сучасному етапі $\epsilon$ можливість підштовхнути прийняття цифрових технологій і почати звужувати прогалини в доходах, які давно стримують розвиток сільських територій.

В умовах пандемії, коли робоча сила стала менш мобільною, а кількість вакансій скоротилася, європейський ринок праці отримав свою порцію викликів і ризиків. До прикладу, працівників рекрутингових агентств перенесли роботу до парків [15]. Обіди в Zoom, психометричні дистанційні тести, співбесіди у парках, субсидіювання робочих місць державою, “передислокування талантів" (коли, 
наприклад, перемістили обробників багажу аеропорту на склади електронної комерції), навчання наявних працівників компаній цифровим, мовним та іншим навичкам, - ось далеко неповний перелік індикаторів адаптації європейського ринку праці. Дизайнери студії Dutch Invertuals розробили компактні офіси для голландського оператора парків відпочинку Droomparken, як виявилося, ще у 2018 р. Тоді чотири робочі простори з гофрованого алюмінію та дерева були встановлені у парках Нідерландів. Робоча зона складалася із столу і м'якого кутка, на якому можна відпочити. За словами дизайнерів, ці місця були створені для того, щоб “вільно мріяти, працювати та творити” [16]. Дизайн таких офісів на початках з пандемією не був пов'язаний, проте зараз цілком реально, що такі офіси стануть новою світовою тенденцією.

Світова індустрія гостинності реагує на ковідні виклики доволі гнучко. Першими "спіймали хвилю" найвідоміші музеї Європи та США, які й до пандемії створили деякі он-лайн тури. Лувр вже у середині березня 2020 р. відкрив на своєму сайті кілька віртуальних маршрутів галереєю. Так само зробили Музей сучасного мистецтва “МоМA” у США, музей Ван Гога у Нідерландах та інші [17]. В Україні тенденцію теж підтримала низка музеїв.

Як сповіщають туроператори, суттєво зріс запит на індивідуалізовані тури відпочинку, у т.ч. у плавучих готелях, у модульних відпочинкових будиночках, які можна розмістити у будь якому місці. У США вже апробовано варіант проведення концерту у бульбашках [18].

На просторові обмеження світ реагує розгортанням платформи цифрових додатків: цифрова доставка, цифрові послуги, цифрові розваги, цифровий шопінг, цифровий банкінг, он-лайн прийоми лікарів. Пандемія Covid-19 зумовила зміну урбаністичних ландшафтів, або принаймні пришвидшила реалізацію цих змін: відбулася переорієнтація на дистанційні чи індивідуалізовані форми праці, навчання, дозвілля, зросла роль громадських просторів, малих архітектурних форм у торгівлі і громадському харчуванні, нові автономні форми відпочинку.

\section{Список літератури:}

1. European Committee on Democracy and Governance and COVID. URL: European Committee on Democracy and Governance and COVID-19 (coe.int)

2. A European Green Deal. Striving to be the first climate-neutral continent. URL: https://ec.europa.eu/info/strategy/priorities-2019-2024/european-green-deal_en

3. Стасюк I. Як змінився Париж за шість років мерства Анн Ідальго ? / Ірина Стасюк. URL: Як змінився Париж за шість років мерства Анн Ідальго? Хмарочос (hmarochos.kiev.ua)

4. Біля визначних пам'яток Парижа висадять сади й гаї (проект). URL: Біля визначних пам'яток Парижа висадять сади й гаї (проект) | Хмарочос (hmarochos.kiev.ua)

5. У Барселоні тестують суперквартали без автомобілів. URL: У Барселоні тестують «суперквартали» без автомобілів | Хмарочос (hmarochos.kiev.ua) 
6. Окамура O. Пандемія змінить наші будинки та міста / Осаму Окамура. URL: Пандемія змінить наші будинки та міста | Збруч (zbruc.eu)

7. В Італії занедбані трамвайні колії перетворили на парк. URL: В Італії занедбані трамвайні колії перетворили на парк (фото) - Свідок (svidok.online)

8. Шевченко Л. 2030-й починається у 2020-ому. Кріс Скіннер про цифровий світ. /Лев Шевченко. URL: 2030-й починається у 2020-му. Кріс Скіннер про цифровий світ $\mid$ processer.media

9. Буртик I. У магазинах Японії працюють роботи: люди керують ними з дому / Ірина Буртик. URL: Японські роботи, якими за допомогою VR керують люди: відео (24tv.ua) (вересень 2020)

10. Роботи-офіціанти: у Нідерландах придумали як вберегти клієнтів ресторану від Covid-19. URL: Роботи-офіціанти: у Нідерландах придумали, як вберегти клієнтів ресторану від - Інтересно (interesno.net.ua)

11. Бондаренко K. Вчені створили робота, який знищує коронавірус / Катерина Бондаренко. URL: Вчені створили робота, який знищує коронавірус Суспільство | OBOZREVATEL

12. Поляки розробили розумний візок. Тепер не треба буде стояти в черзі. [Електронний ресурс]. - режим доступу: Поляки розробили розумний візок. Тепер не треба буде стояти в черзі - Monitor Info (monitor-press.info)

13. Рудченко A. Як коронавірус вплине на архітектуру: ідеї відомих дизайнерів / Аліна Рудченко. URL: Архітектура i Covid-19: як коронавірус вплине на будівництво (24tv.ua) (12.11.2020)

14. Поскробок Ю. Україна увійшла в 10-ку країн з найбільшим зростанням прибутку від $e$-комерції. / Юлія Поскробок. URL: Україна увійшла в 10-ку країн в Payoneer's Global Seller Index у 2020 (24tv.ua)

15. Kahn M. Zoom lunch? Walk in the park? Europe's rucruiters adapt to Covid /Michael Kahn, John Revill. URL: Zoom lunch? Walk in the park? Europe's recruiters adapt to Covid (msn.com)

16. У Нідерландах відкрили одномісні офіси у парку. URL: У Нідерландах відкрили унікальні одномісні офіси у парку (propertytimes.com.ua)

17. Балабанова M. Музейні проекти під час пандемії та прогнози розвитку. / Марія Балабанова. URL: Музейні проєкти під час пандемії та прогнози розвитку | Your Art (supportyourart.com)

18. У США рок-гурт влаштував концерт в бульбашках. URL: У США рок-гурт влаштував концерт в бульбашках (відео) (bit.ua) 


\title{
УТВЕРДЖЕННЯ ПОЛІТИЧНОЇ ЕТИКИ ЛІВОГО РАДИКАЛІЗМУ В КУЛЬТУРНІЙ ТВОРЧОСТІ
}

\author{
Автушенко Ірина Борисівна, \\ доктор історичних наук, доцент \\ кафедра теорії та історії держави і права \\ Національний транспортний університет, м. Київ
}

Автушенко Олександр Семенович, кандидат педагогічних наук, доцент спеціальна кафедра № 2 IC33І КПІ ім. Ігоря Сікорського, м. Київ

Моральні цінності й норми, що стосуються політичного світу, його інститутів, політичного світогляду і поведінки членів того чи іншого суспільства, у сукупності складають політичну етику. Політична етика лівого радикалізму це нормативна основа політичної діяльності найбільш радикальних сил, що визнають тільки свою монополію на владу, в процесі завоювання й утримання якої не дотримуються загальноприйнятих етичних норм. Однією з визначальних рис етики лівого радикалізму $\epsilon$ прагнення до встановлення тотально регульованої поведінки як суспільства у цілому, так і кожного індивідуума.

До ліворадикального крила належала й більшовицька партія. Прийшовши до влади, остання визначала фундаментальні засади у сфері економіки, політики i, звичайно ж, культури. Поступова монополізація влади більшовиками викликала глибоку деформацію критеріїв моральності. Будь-яка влада вважає добром те, що iї зміцнює, а злом те, що їй протидіє.

Залізним правилом для творчої інтелігенції ставало: роби тільки так, як вимагає етика партійного керівництва. Політичні симпатії нерідко ставилися більшовиками вище таких загальнолюдських понять як кохання, дружба й сім'я. Ця складова етики більшовизму бере початок ще у «Катехізисі революціонера» С. Нечаєва, де зазначено, що «для революціонера морально все, що сприяє торжеству революції. Аморально все, що заважає йому» [1, с. 82]. С. Нечаєв вимагав із презирливістю ставитися до суспільної думки і ненавидіти суспільну мораль. Тобто, всі особисті почуття повинні підкоритися суспільному обов'язку.

Культурна творчість, яка в різні способи заганялася в рамки більшовицьких ідеологічних догм, була віддзеркаленням цих світоглядних засад. У руслі цього кредо, наприклад, написана відома новела М. Хвильового «Я - романтика» (1923), де відтворено вбивство матері власним сином заради революційних обов'язків. У цьому трагічному творі автор аналізує одну з основних колізій часу - гуманізм й фанатизм. Розкриває суперечність між одвічним ідеалом любові й тим беззастережним служінням абстрактній ідеї, що вимагає зречення всього 
людського. Герой перестає бути особистістю, яка сама розпоряджається власним життям і власними рішеннями, він стає гвинтиком і заручником могутньої системи. Б. Лавреньов у оповіданні «Сорок перший» (1924), показує вбивство юнака коханою за його приналежність до протилежного політичного табору. Літературною класикою радянського часу стала п'єса Ю. Треньова «Любов Ярова» (1926), в якій майстерно висвітлено підпорядкованість сімейних почуттів політичним пристрастям.

Крайньою формою було доносительство на батьків, канонізоване в образі Павлика Морозова, якому присвячували поеми, вірші й оповідання. Наприклад, поема В. Вітковського «Павло Морозов», яку було надруковано в журналі «Червоний шлях» за 1935 рік. Герой поеми у суді над батьком виголошує промову: «Ще й кажуть батько він мені! Ще й кажуть рідна кров. Не смійте! Ворожу тінь його $з$ ланів гарячим виром праці змийте!» [2, с. 87]. Поряд із доносами на батьків популярним було і зречення їх від них. Взагалі цінність родинних почуттів була поставлення під сумнів. Їм протиставлялася класова солідарність і класова ненависть.

Ці приклади свідчать про драматизм боротьби, про гостроту конфліктів класового характеру, про зіткнення людей різної політичної орієнтації. Отже, на основі вивчення ряду творів художньої літератури, стає очевидним той факт, що в українській літературі переважаючими були твори, що схвалювали, пропагували доносительство та «батькопродавство».

Дегуманізуючим чинником української літератури стає пріоритет класового над загальнолюдським, унітарного над особистим і самобутнім. На перший план у літературі виходить соціальне замовлення: боротьба 3 куркульством, націоналізмом, шкідниками, з недоносительством на рідних тощо. Прагнучи перетворити літературу у велике пропагандистське відомство з виробництва «художніх» ідеологічних стереотипів, партійні ідеологи домагалися іiі переорієнтації на масового читача. Але орієнтація на масову літературу i масового читача часто позбавляла твори художності та неповторної цінності авторського бачення.

Не оминула етика лівого радикалізму й українське кіно, яке повинно було також мати «класову спрямованість». Наприклад, один із перших українських кінорежисерів В. Гардін на замовлення Всеукраїнського фотокіноуправління (ВУФКУ) створює кінороман «Остання ставка містера Енніока» (1922) за оповіданням О. Гріна «Життя Гнора» [3, с. 47]. Основою сюжету цього твору був традиційний любовний трикутник: Гнор - Кармен - Енніок. Шляхом обману Енніок завозить свого суперника Гнора на безлюдний острів, але за збігом щасливих обставин Гнорові вдається врятуватися і повернутися до Кармен. Енніок кінчає життя самогубством, а Гнор одружується з Кармен. В. Гардін, слідуючи партійним настановам, переробив оповідання, надавши йому класової спрямованості: Енніока було перетворено на власника заводу, а Гнора - на інженера-пролетаря. Між ними точиться «класова боротьба», Кармен відступає на задній план. Більшовики забирають у Енніока завод, а Гнор стає на чолі повсталих робітників. Отже, втілення сюжету оповідання О. Гріна у фільмі не має нічого спільного з оригіналом. 
Й. Сталін, як і будь-який деспот, був вельми не байдужим до свого іміджу в середовищі наукової і творчої інтелігенції. Він дбав, щоб кожне його слово, вчинок негайно широко розповсюджувалося, як чергове «геніальне» нововведення в науку, літературу й мистецтво. Всіляко намагався підім'яти під себе найвизначніших представників інтелігенції. Не оминув цієї долі й О. Довженко. В особистих зустрічах із ним у 1935-1936 роках Й. Сталін висловив думку про втілення в кіно образу українського Чапаєва-Щорса, але цим не обмежився. Він розтлумачив митцю, що картина має відбивати класовий характер революції і громадянської війни, дружбу українського й російського народів у боротьбі проти експлуататорів. О. Довженко виконав завдання вождя, тому що про ігнорування вказівок не могло бути й мови.

Таким чином, творча інтелігенція в агонії самознищення допомагала утвердженню етики лівого радикалізму в усіх іiі формах, i, чи не в першу чергу, жертвою якого сама ж стала. Сталінські засоби ідеологічного «виховання» перетворили іiі в особливий «соціальний прошарок» суспільства. Більша й найкраща частина української національної еліти у 1930-ті роки пройшла тяжкий шлях на Голгофу (звідки повернулися одиниці), інша - змушена була «під керівництвом» робітничого класу й Комуністичної партії брати «активну участь у соціалістичному й комуністичному будівництві».

Поява таких творів, як роман М. Хвильового «Вальдшнепи», насиченого пристрастями політичних роздумів-пошуків i справжніми, а не казеннорегламентованими ідеологічними суперечками, могла бути тільки винятком.

На початку 1930-х років все наполегливіше просувається «соціальне замовлення» на викриття «художніми засобами» підривної діяльності української буржуазно-націоналістичної інтелігенції. У таких викриттях змагалися між собою й не мало письменників, у тому числі й відомих.

Дух шпигуноманії і викриття пронизує багато творів того часу. Це, зокрема, романи В. Гжицького «Семен Вовгура» (1932), С. Скляренка «Бурун» (1932), О. Донченка «Зіркова фортеця» (1933) та «Море відступає» (1934), Н. Рибака «Київ» (1938).

У 1930-ті роки із посиленням ідеологічного тиску у творах, присвячених революції і громадянській війні, великого поширення набули стереотипи, що спрощували, а то й спотворювали панораму історичних подій. Центральною фігурою творів про революцію і громадянську війну стає Й. Сталін, а також М. Щорс, О. Пархоменко, Г. Котовський. Отже, внаслідок однобічного підходу складна історія країни дедалі більше обмежувалася висвітленням діяльності незначного кола канонізованих осіб.

Щоб оцінити радянську культуру 1920-30-х років із позицій сьогодення, важливо зрозуміти, що багато з ії визначальних рис формувалися не самими лише керівними установками, а відтворювали певні ідеали народу, його естетичні й духовні потреби. Офіційно продеклароване переможнооптимістичне світосприймання, спираючись на настрої «знизу», на ще незатьмарену віру в добро й справедливість, на прагнення щастя як природньої людської потреби, обумовило оптимізм радянського мистецтва 1930-х років. Час прагнув бачити свого героя молодим і привабливим, адже люди після революції, 
воєнного комунізму та суворих 1920-х років стихійно прагнули краси і бодай відносного комфорту.

Наприкінці 1930-х років, коли колективізація сільського господарства була фактично завершена, з'явились твори, в яких оспівувалися досягнення колективного ведення господарства на селі, життя селян у нових умовах, де особисте щастя було невіддільним від щастя всесоюзного. Це і п'єса О. Корнійчука «В степах України», художні полотна Ф. Кричевського «Квітуча Україна», «Веселі доярки», кінофільми І. Пир'єва «Багата наречена» та «Трактористи» тощо. Виступаючи на VII виробничій кінонараді (1935), секретар ЦК ВКП(б) А. Андрєєв зауважив: «Треба створювати картини, що віддзеркалюють перемоги суцільної колективізації на селі, стаханівський рух у місті, показувати героїв нового життя. Потрібно створювати картини серйозні й веселі» [4, с. 103]. А. Андрєєв також зауважив, що товариш Й. Сталін у своєму виступі сказав: «Жити стало веселіше, хочеться посміятися!», отже, необхідно відповісти на ці заклики й дати можливість робітнику, селянину як слід посміятися [4, с. 103].

Художники, літератори і майстри кіно «відповідали». Майже в усіх творах того періоду оспівується щастя колгоспного життя і казковий над усяку людську міру достаток (О. Кундзич у «Родичах» і К. Гордієнко в «Дітях землі» трохи стриманіше). Разом з тим у численних творах про соціалістичне перетворення села читач не знаходив навіть згадки про трагедію українського села, пов'язану з голодом 1932-1933 рр., з винищенням його основної виробничої сили під час сумнозвісного розкуркулення.

Характерним для творів 1930-х років була масова танцювальна ейфорія, що охопила українське колгоспне селянство. Танцюють, святкуючи перемогу над класовим ворогом або просто висловлюючи радість причетності до сталінської доби, - у «Диктатурі» I. Микитенко, у «Гопаку» М. Дукина, в «Удай-ріці» О. Десняка.

Загальновідомо, що життя колгоспників, які майже нічого не одержували за зароблений трудодень, було жалюгідним і несхожим на те, що змальовували у своїх творах радянські митці. Тоді у глядачів і читачів створювалося враження, ніби всі питання розвитку народного господарства, добробуту народу остаточно вирішені, а всі негаразди - від «недобитих ворогів», які нібито шкодять будівництву соціалізму в країні. Отже, тією чи іншою мірою численні митці робили свій внесок у створення культурної платформи ідеології сталінізму, допомагали розкручувати маховик насильства, жертвою якого ставали й самі.

Отже, аналіз основних, суспільно значимих тенденцій у культурному житті республіки 1920-х - 30-х років дає підстави зробити узагальнюючий висновок, що в українській культурі поступово утверджується етика лівого радикалізму як складова тоталітарної політики більшовизму.

На початку 1920-х років партійно-державна влада свої морально-політичні засади етики лівого радикалізму втілювала у культурне життя більш-менш лояльними методами, тобто через пропагування й агітацію. Під їхнім впливом створювалися твори, що пропагували доносительство та «батькопродавство», боротьбу із куркульством, націоналізмом, шкідниками і зрадниками. 
Починаючи 3 другої половини 1920-х років більшовицька влада, намагаючись впровадити у життя свої принципи, вимагала від творчої інтелігенції створення творів, що відповідали б усім вимогам правлячої партії.

Таким чином, виконуючи вимоги більшовицького керівництва, творча інтелігенція поступово утверджувала етику лівого радикалізму в культурній творчості, яка наприкінці $1920-x$ - середини 30-х років стала домінуючою у духовному житті суспільства. Сталінська ідеологія, що ставила за мету створення нового однорідного суспільства і «нової» людини, заперечувала загальнолюдські моральні цінності й поступово утвердилася у художній творчості як визначальна.

\section{Список літератури}

1. Нечаев С. Катехизис революционера. Родина. 1990. № 2. С. 82-83.

2. Вітковський В. Павло Морозов. Червоний шлях. 1935. № 12. С. 84-92.

3. Берест Б. Історія українського кіна. Нью-Йорк: Наукове товариство ім. Т. Шевченка, 1962.271 с.

4. Партия о кино. М. : Госкиноиздат, 1939. 141 с. 


\section{ДО ПИТАННЯ ПРО МЕТОДИ, ОСОБЛИВОСТІ ФІНАНСУВАННЯ І НАСЛІДКИ РАДЯНСЬКОЇ ІНДУСТРІАЛІЗАЦІї}

Нікітенко Костянтин Вікторович

Доктор історичних наук, доцент, завідувач кафедри менеджменту мистецтва у Львівській національній академії мистецтв, м. Львів, Україна

Свого часу радянська пропаганда чимало зробила для того, щоб певна частина населення СРСР щиро вважала, що живе «у найвільнішій i найщасливішій країні». Російська пропаганда й нині не соромиться використовувати перевірені часом лекала. Популяризуються радянські міфи (яскравий приклад - «герої-панфіловці»), Й. Сталіна визнають «вдалим менеджером», який прийняв країну «в лаптях», а залишив з ядерною бомбою, тощо. Всіляко акцентують на досягненнях індустріалізації 1930-х рр. Втім, надважливим $€$ питання: а яку ціну довелося заплатити за всі «будови століття»? Наголосимо, що промисловий стрибок країна мала робити за надзвичайно несприятливих умов. Брак кваліфікованих кадрів, сучасного устаткування, економічна відсталість, а найголовніше - постійний брак коштів, відсутність зовнішнього фінансування, і як наслідок - розрахунок виключно на внутрішні резерви, які були далеко не безмежні. А грошей треба було чимало. Так, кошторисна вартість Запоріжсталі - найбільшої в Україні новобудови за роки довоєнних п’ятирічок - дорівнювала 933 млн руб. Вартість усіх об'єктів Криворіжсталі становила понад 800 млн руб. тощо [1, с. 222]. Масштабні соціальні експерименти-злочини - колективізація, розкуркулювання, примусова праця політичних в'язнів, а також розгортання соціалістичного змагання i боротьба за режим економії - стали головними джерелами фінансування «будов століття».

Ресурси на індустріалізацію забезпечувалися шляхом карколомного маневрування - встановленням голодного пайка для «непріоритетних» галузей господарства, що призводило до виснаження економіки країни. Принциповою особливістю індустріалізації стало те, що, на відміну від більшості країн світу, розвиток промисловості здійснювався не заради задоволення споживчих потреб населення і не заради поліпшення життя людини. Навпаки, споживання промислової продукції для населення обмежували, відтак рівень життя падав, на недосяжний дефіцит перетворювали навіть товари першої потреби. Держава стала не тільки власником промислових об'єктів, а й головним споживачем виробленої ними продукції. Сталіну насамперед потрібен був розвиток важкої промисловості - метал на виробництво танків, гармат, бойових кораблів тощо. Людей жорстоко карали за прогули і «шкідництво». Робітники недосипали й недоїдали, втрачали здоров'я, а іноді й життя, намагаючись виконати і «постахановському» перевиконати плани-завдання... 
Для забезпечення робітників харчовими продуктами запровадили карткову систему. «Забірні книжки» на продукти вперше з'явилися в Одесі, Маріуполі й Херсоні у другому кварталі 1928 р. А вже за рік картки на хліб активно використовували у всіх містах СРСР [2, с. 233]. Зауважимо, що карткову систему запроваджували з ініціативи місцевої влади, тому норми відрізнялися. Втім, завжди дотримувалися найважливішого принципу - робітників державних заводів і фабрик постачали у першу чергу. Поступово не тільки хліб, а й усі основні види продовольства почали розподіляти за картками. Так, робітники Донбасу, які належали до першої групи постачання продуктами (найкраще забезпеченої), у 1929-1930 рр. отримували на день по 800 г хліба і 200 г м'яса. Їхня місячна норма становила 3 кг круп, 800 г риби, 600 г масла, 750 г олії, 1,5 кг цукру, десяток яєць [2, с. 233-234]. Картки на хліб (після значного його подорожчання) скасували 1935 р., на решту продуктів - трохи пізніше, натомість розповсюдили іншу новацію - «обмеження продажу товарів в одні руки».

Визначальною особливістю функціонування СРСР стала планово-командна система керування. У повній відповідності провідним принципам літературних антиутопій влада намагалася поставити під свій контроль усі сфери життя населення. У країні панувала диктатура плану. Загнати в задушливі рамки планів намагалися навіть ті процеси, які не підлягали плануванню апріорі. Наприклад, передбачити рух грошей відповідно до руху товарів у сільському господарстві нереально. На результати господарювання аграрного сектору істотно впливають коливання погодно-кліматичних умов, інші природні чинники, тому наперед визначити врожаї зерна, приріст стада худоби, вихід сільськогосподарського продукту дуже складно. Не кажучи вже про те, що основним завданням роботи банківських інституцій завжди було отримання прибутку, що ставило банківську систему СРСР перед принциповою дилемою: за будь-яку ціну виконувати отримані вказівки, навіть якщо вони суперечили ринковій кон'юнктурі, або під свою відповідальність послуговуватися в роботі принципами економічної доцільності.

Остаточну крапку в цьому питанні поставив Й. Сталін, наголосивши у своєму виступі на XV з'їзді: «Наші плани є не плани-прогнози, не плани-здогади, а плани-директиви, які обов'язкові для керівних органів» [3, с. 69]. В умовах сталінізації суспільства людину, яка наважувалася заперечувати самому лідерові, могли чекати тільки репресії. С. Струмиліну, провідному фахівцеві Держплану СРСР, який брав безпосередню участь у розробці п’ятирічних планів, приписують вислів: «Краще стояти за високі темпи, ніж сидіти за низькі» [4, с. 134]. Відтепер плани прирівнювалися до наказів і мали виконуватися за будь-яку ціну. Часто при цьому абсолютно ігнорували економічну ситуацію, що завдавало нечуваної шкоди економіці країни. Фахівці регулярно фіксували «колосальне розходження» планів-директив і дійсності.

У той час, як у країні було встановлено жорсткий режим економії, коли потрібно було піднімати промислове будівництво, коли тисячі ударників 
виконували-перевиконували плани-завдання, намагаючись досягти позитивного економічного результату, на рахунках промислових підприємств накопичувалися мільйони невикористаних коштів. Причина - бездумне виконання планів-директив, без урахування кон'юнктури ринку.

Так, у 1929/1930 р. роботи, на які Промбанк, відповідно до складених заздалегідь планів, виділив кошти відразу в повному річному обсязі, були виконані в середньому тільки на 70\%, а в деяких галузях і значно менше: приміром, заводи з виробництва будівельних матеріалів освоїли всього 61\% наданих коштів, підприємства склопорцелянаоб'єднання - 67\% тощо [5, арк. 18]. Величезні суми мертвим вантажем осідали на банківських рахунках у той час, коли їх так не вистачало народному господарству республіки для збалансованого розвитку через те, що в країні існувала структурна диспропорція: розвиток промисловості групи А (виробництво засобів виробництва) значно випереджав групу Б (виробництво предметів споживання), яка постійно отримувала фінансування за залишковим принципом, що відразу відчуло на собі населення країни.

Так, у Зінов’євську (нині Кропивницький) було заплановано збільшити потужність електростанції, на що авансом виділили кошти у повному обсязі. Втім, за рік не дійшло навіть до монтажно-будівельних робіт - не затвердили проект. Миколаївська електростанція роками очікувала свого повністю профінансованого розширення. «Граничний дефіцит мідного дроту, кабелів i стовпів», а також «нестача кваліфікованої електротехнічної сили» й на цьому об’єкті перекреслили всі плани [5, арк. 23, 23 зв].

Костянтинівський скляний завод у зв’язку з проблемами під час затвердження проектів будівництва тільки у 1929/1930 р. недовиконав робіт на понад 100 тис. руб. Лисичанській завод зумів виконати робіт тільки на 1084 тис. руб. 3 виділених 2400 тис. руб. Причина - «запізнення в отриманні робочих креслень, неповна реалізація фонду будівельних матеріалів». За рік завод отримав тільки 22\% потрібних будівельних матеріалів і 50\% цементу тощо [5, арк. 20, 20 зв.]. Проблеми з ефективним використанням наданих коштів мав увесь промисловий комплекс республіки. Приміром, підприємства Союзкоксу за 1930 p. використали тільки 29\% наданого фінансування. Завод в Алчевську при плановому завданні на 7950 тис. руб. виконав будівельно-монтажних робіт лише на 3350 тис. руб. (42\%); Харківський тракторний завод, отримавши 31897 тис. руб., зумів виконати робіт тільки на 18468 тис. руб. (57,9\%) тощо. Сумний антирекорд установив Луганський завод гірничозаводського обладнання - 17,5\% виконання планового завдання. На цьому тлі великою перемогою видається робота підприємств хімічної промисловості, які виконали план на 88\%. Втім, вказані підприємства отримали на виконання робіт 34227 тис. руб., а освоїли 30154 тис. руб., отже мертвим вантажем осіло «лише» 4073 тис. руб [5, арк. 24 зв, 25 зв, 26 зв]. Також у республіці 1930 р. повністю провалено план закупівлі імпортного обладнання, на що було виділено 21,2 млн руб., а придбати його 
вдалося лише на 1,5 млн руб. (7,1\%). Вітчизняного обладнання з виділених 6,7 млн руб. було закуплено всього на 1 млн руб. (14,9\%), проектних робіт виконано на 44,8\% тощо [5, арк. 24 зв].

Головною проблемою стали не так ускладнення на будівництвах (коли вони цілком могли мати місце, бо уникнути їх повністю під час виробничих процесів неможливо у принципі), як величезна неефективність використання коштів. Багато економічних проблем радянська влада сама собі штучно спричинила, агресивно реалізовуючи класову позицію. Так, знищення приватних виробників обернулося значним негативним економічним ефектом. Адже саме приватники великою мірою забезпечували ринок необхідними населенню товарами першої потреби. Вони ж постачали державним підприємствам сировину й напівфабрикати. У $1925 / 1926$ р. приватний постачальник забезпечував підприємства Папіртресту на 28,3\% підсобними матеріалами, на 5,5\% - паливом і на 45,4\% - ремонтно-будівельними матеріалами. Тютюнтрест і Махортрест також 30\% матеріалів отримували від приватного постачальника тощо [6, арк. 23]. Отже, суто політична ліквідація приватного виробника негайно спричинила цілу низку принципових проблем із постачанням підприємств сировиною і матеріалами.

Втім, подібна нелогічність, тотальне підпорядкування економічних процесів політичним міркуванням стали характерною ознакою планово-командної економіки, яка у своїй роботі повністю ігнорувала не тільки ринкові механізми і принципи, а й елементарну економічну доцільність. «Плани-директиви» виснажували економіку країни. Утопічне переконання, що для успішного будівництва слід тільки акумулювати якомога більше коштів, в умовах повного ігнорування всього складного комплексу виробничих процесів призводило до того, що величезні суми роками без жодного руху лежали на банківських рахунках у той час, коли їх так не вистачало підприємствам, які виготовляли товари повсякденного вжитку. Це призводило до масштабного нецільового використання коштів.

Можна зрозуміти директорів підприємств, які, маючи на рахунках величезні гроші, прагнули хоч якось вкласти їх у справу. Часто сировину, матеріали, обладнання закуповували просто «про всяк випадок». Так, на будівництвах Донецького регіону 1937 р. було закуплено «про запас» зайвого обладнання i матеріалів майже на 12 млн руб. Подібна практика призводила до затоварювання підприємств, склади були перевантажені непотрібним обладнанням, що створювало додаткові ускладнення. Наприклад, завод «Азовскло» (Донеччина) цілий рік намагався придбати шахтну лебідку, проте за результатами ревізії з'ясувалося, що на складах заводу зберігаються 2 лебідки, про які керівництво уже й забуло. Всього на 1937 р. на 100 найбільших будівництвах Донбасу «про всяк випадок» було закуплено «добра» на понад 36 млн руб., яке осіло мертвим вантажем [7, с. 4]. Та цілком у дусі часу й офіційної партійної лінії у неефективності роботи на «будовах століття» Комуністична партія звинуватила 
виключно «троцькістсько-бухаринських шкідників», які «навмисно й свідомо» зривали плани i закуповували для промислових підприємств абсолютно непотрібні запаси. Працівники обласної контори Промбанку, за результатами перевірок 1938 р., зробили доповідь на нараді будівельників при Донецькому обкомі КП(б)У, закликаючи покінчити зі «шкідництвом» [7, с. 4]. Позиція керівників тільки консервувала і в перспективі поглиблювала проблему, бо визначальні принципи роботи планової командно-адміністративної системи не підлягали критиці.

Фактично перші п’ятирічні плани було провалено майже за всіма показниками i насамперед - за обсягом виробленої продукції. Замість запланованого зростання, продуктивність сільського господарства різко впала. Обіцяне значне поліпшення життєвого рівня населення виявилося нереалізованим - на селі голодною смертю померли мільйони людей, стрімко погіршувався життєвий рівень міських жителів. Собівартість промислової продукції з кожним роком збільшувалася, значно перевищуючи і показники 1913 p., i аналогічні показники у розвинутих країнах (парадокс - реальні тенденції були протилежні запланованим). Директивний тиск на директорів заводів i фабрик з тим, щоб урегулювати собівартість, прямо позначався на кінцевому продукті - радянські товари були дуже невисокої якості. Відповідно, замість обіцяного у планах щорічного збільшення виробництва товарів народного споживання у країні запровадили карткову систему. На дефіцит перетворилися навіть харчові продукти та першої потреби. Паперові рекорди й цифри «досягнень» спричиняли хаос у роботі системи, надзвичайно заплутували показники офіційної звітності, яка чимдалі впевненіше жила своїм окремим життям. Реальність дуже відрізнялася від пропагандистської казки. Населення регулярно закликали «потерпіти», «затягти паски», відкласти свої особисті інтереси заради будівництва чи то чергового заводу-гіганта, чи то «світлого майбутнього». Звісно, при цьому не афішували того факту, що більшість країн світу теж проводила свою індустріалізацію, яка, втім, ніде не супроводжувалася голодомором, мільйонними жертвами, репресіями і знущанням 3 власного народу.

\section{Список літератури}

1. Кульчицький С.В. Україна між двома війнами (1921-1939 рр.). К.: Вид. дім «Альтернативи», 1999. $336 \mathrm{c}$.

2. Литвин В.М. Україна: міжвоєнна доба (1921-1938 рр). К.: Вид. дім «Альтернативи», 2003. $512 \mathrm{c.}$

3. XV съезд Всесоюзной Коммунистической партии (б). Стенографический отчет. М., Л.: Госиздат, 1928. 1416 с.

4. Кульчицький С.В. Україна між двома війнами (1921-1939 рр.). К.: Вид. дім «Альтернативи», 1999. 336 с.

5. Центральний державний архів вищих органів влади та управління України. Ф. 34. Оп. 16. Спр. 3136. 77 арк. 
6. Там само, Ф. 337. Оп. 1. Т. 2. Спр. 5752.50 арк.

7. Дубицкий Запасы на всякий случай. Финансовая газета. 1938. 6 вересня. С. 4. 


\title{
ПРОВАДЖЕННЯ У СПРАВАХ ПРО ОСКАРЖЕННЯ РІШЕНЬ ТРЕТЕЙСЬКИХ СУДІВ
}

\author{
Козирсва Валентина Петрівна, \\ к.ю.н., доцент, \\ професор кафедри господарського, повітряного та космічного права \\ Національний авіаційний університет, \\ Юридичний факультет

\section{Мельниченко Ірина Степанівна} \\ здобувач вищої освіти, \\ Національний авіаційний університет, \\ Юридичний факультет, \\ Україна
}

У процесі розгляду та вирішення справи третейський суд розв'язує різні за змістом та юридичним характером питання: вирішує справу по суті, вирішує клопотання сторін тощо. Судження і волевиявлення суду по цих чи інших питаннях мають владний характер і втілюються у від-повідну процесуальну форму - у форму процесуальних рішень.

Для третейських рішень не передбачена можливість їх апеляцій-ного або касаційного оскарження та перегляду за нововиявленими обставинами. У цьому аспекті слід погодитись 3 обгрунтованою кри-тикою, якій була піддана термінологія, що використовується у ст. 51 Закону України «Про третейські суди» та ст. 389 ЦПК, а саме термін оскарження рішення третейського суду. Застосування цього терміну стосовно третейського рішення $\epsilon$ абсолютно неправильним, оскільки існує суттєва різниця між інститутами оскарження i оспорювання.

Надання учасникам процесу права оскаржити судове рішення $є$ од-нією 3 гарантій права на справедливий та неупереджений розгляд справи, передбачених ст. 6 Конвенції про захист прав людини і осно-воположних свобод. Стаття 51 Закону встановлює загальне правило, що рішення третейського суду $\epsilon$ остаточним й оскарженню не підлягає. Однак із цього правила законодавець встановлює окремі винятки, коли рішення може бути оскаржене та скасоване судом.

Відповідно до ч. 1 ст. 389і ЦПК сторони, треті особи, а також осо-би, які не брали участі у справі, у разі якщо третейський суд вирішив питання про їх права і обов'язки, мають право звернутися до суду із заявою про скасування рішення третейського суду. Заяву про скасуван-ня рішення третейського суду може бути подано до компетентного суду сторонами, третіми особами протягом трьох місяців 3 дня прийняття рішення третейським судом, а особами, які не брали 
участь у справі, у разіякщо третейський суд вирішив питання про їх права $\mathrm{i}$ обов'язки, — протягом трьох місяців з дня, коли вони дізналися або повинні були дізнатися про прийняття рішення третейського суду.

Заява, подана після закінчення строку, залишається без розгляду, якщо суд за заявою особи, яка ії подала, не знайде підстав для поновлення строку, про що постановляється ухвала. У випадку якщо заява не підлягає розгляду в судах у порядку цивільного судочинства; у провадженні цього чи іншого суду є справа iз спору між тими самими сторонами, про той самий предмет і 3 тих самих підстав; після смерті фізичної особи, а також у зв'язку з припиненням юридичної особи, які є однією із сторін у справі, спірні правовідносини не допускають правонаступни-цтва, а також у разі якщо рішення третейського суду оскаржено 3 під-став, не передбачених законом, суд відмовляє у відкритті провадження щодо оскарження рішення третейського суду.

Заява про скасування рішення третейського суду подається у письмовій формі і підписується особою, яка його оскаржує, чи ії представником. У заяві мають бути зазначені:

1) найменування суду, до якого подається заява;

2) ім'я (найменування) особи, яка подає заяву, а також ім'я (на-йменування) iіi представника, якщо заява подається представником, їх місце проживання (перебування) або місцезнаходження;

3) ім'я (найменування) учасників третейського розгляду, їх місце проживання (перебування) або місцезнаходження;

4) найменування та склад третейського суду, який прийняв рішення;

5) відомості про рішення третейського суду, яке-оскаржується, а саме: номер справи, дата і місце прийняття рішення, предмет спору, зміст резолютивної частини рішення;

6) дата отримання особою, яка звертається із заявою, рішення тре-тейського суду, яке оскаржується;

7) підстава для оскарження і скасування рішення третейського суду;

8) зміст вимоги особи, яка подає заяву;

9) перелік документів та інших матеріалів, що додаються до заяви.

Відповідно до ч. 3 ст. 389 ЦПК до заяви повинні бути додані ори-гінал рішення третейського суду або належним чином завірена його копія. Під належним чином завіреною копією розуміється щодо рішен-ня постійно діючого третейського суду - копія, завірена головою постійно діючого третейського суду, а копія рішення третейського суду 1290 для вирішення конкретного спору має бути нотаріально завірена. Крім цього додаються: оригінал третейської угоди або належним чином за-вірена іiі копія; документи, які подані на обгрунтування підстав для скасування рішення третейського суду; документи, що підтверджують сплату судового збору та оплату витрат на інформаційнотехнічне за-безпечення розгляду справи; довіреність або інший документ, що по-свідчує повноваження представника; копії заяви про скасування рішен-ня третейського суду та доданих до неї документів відповідно до кількості учасників судового розгляду. 
Заява про скасування рішення третейського суду, подана без додержання вимог, визначених у цій статті, а також у разі несплати суми судового збору чи неоплата витрат на інформаційно-технічне забезпечення розгляду справи повертається особі, яка ï подала, чи залишається без руху і надається строк для усунення відповідних недоліків.

Після вирішення судом питання про наявність підстав для відкрит-тя провадження щодо оскарження рішення третейського суду суд вчиняє процесуальні дії, пов'язані з підготовкою справи до розгляду.

Слід звернути увагу на положення ст. 389 ЦПК щодо права суду витребувати матеріали справи третейського розгляду. Таке право і кореспондуюча йому можливість стосуються лише матеріалів справи третейського розгляду, який відбувся у постійно діючому третейському суді, оскільки відповідно до ст. 54 Закону України «Про третейські суди» у третейського суду, утвореного на постійній основі, є обов'язок збері-гати матеріали справи протягом 10 років.

Особливістю третейського розгляду $є$ те, що рішення третейського суду $\epsilon$ остаточним та не підлягає апеляційному, касаційному оскарженню та перегляду за ново виявленими обставинами. Для здійснення судового контролю за третейським судом законодавство передбачає застосування особливої оспорювання третейського рішення, яка реалізується в межах провадження у справах про оскарження рішень третейських судів.

Таким чином, оскарження рішень третейських судів за своїм характером $\epsilon$ проявом контрольної функції державних судів, здійснюваної у визначеному законом порядку та обсягах. Під час розгляду справи про оскарження рішень третейських судів державний суд не має права перегляду справи по суті, а лише встановлює ті обставини, які виступають підставами для відмови у державному визнанні результату правозастосовної діяльності третейського суду.

Як правило, скасування компетентним судом рішення третейського суду не позбавляє сторони права повторно звернутися до третейського суду. Виключенням є випадки, передбачені ст. 51 Закону України "Про третейські суди", відповідно до якої спір не підлягає подальшому розгляду в третейських судах якщо:

- рішення третейського суду, скасовані повністю або частково внаслідок визнання компетентним судом недійсною третейської угоди;

- рішення прийнято у спорі, який не передбачений третейською угодою;

- рішенням вирішені питання, що виходять за межі третейської угоди або рішення прийнято у справі, не підвідомчій третейському суду.

Метою провадження у справах про оскарження рішень третейських судів $\epsilon$ перевірка рішення третейського суду на предмет наявності у третейського суду повноважень (компетенції) на вирішення конкретної справи, наявності істотних порушень процесуального характеру під час розгляду справи та винесення рішення, до яких належать відповідність складу третейського суду вимогам закону, дотримання процедури третейського розгляду. Забезпечення рівних можливостей сторонам щодо захисту своїх прав.

Для досягнення зазначеної мети під час провадження у справах про оскарження рішень третейських судів вирішуються наступні завдання, які можна 
поділити на дві групи: 1) підготовка справи до розгляду; 2) з'ясування питання про наявність або відсутність підстав для скасування рішення третейського суду. 3'ясування цього питання пов'язане 3 перевіркою наявності компетенції третейського суду на розгляд спору та полягає у встановленні компетентним державним судом того - чи підвідомча справа, рішення з якої оскаржується, третейському суду, чи рішенням третейського суду не вирішені питання, які виходять за межі третейської угоди та чи не визнано третейську угоду судом недійсною. Крім того, суд встановлює наявність процесуальних порушень в процесі третейського провадження. Процесуальний порядок розгляду судом справ про оскарження рішень третейських судів такий же як встановлений для розгляду справи судом першої інстанції, 3 особливостями, встановленими главою 1 Розділу УІГ ЦПК України.

Окрім рішень третейських судів об'єктом оскарження у встановленому нормами ст. 389,-3 896ЦПК України порядку можуть бути рішення, винесені міжнародним комерційним арбітражем, місце якого знаходиться на території України. Такі рішення можуть бути оспорюванні сторонами до суду відповідно до правил міжнародного договору України та/або Закону України "Про міжнародний комерційний арбітраж".

Порядок оспорювання рішення, винесеного міжнародним комерційним арбітражем встановлений ст. 34 розділу VII "Оспорювання арбітражного рішення" Закону України "Про міжнародний комерційний арбітраж". Крім того, окремі положення щодо оспорювання рішень міжнародного комерційного арбітражу передбачені статтями V та IX Європейської конвенції про зовнішньоторгівельний арбітраж 1961 року.

Отже, на сьогодні в Україні більшість рішень, винесених за результатами розгляду спорів у порядку міжнародного комерційного арбітражу, ухвалюються двома постійно діючими арбітражними установами Міжнародним комерційним арбітражним судом при Торгово-промисловій палати України та Морською арбітражною комісією при Торгово-промисловій палати України. Разом з цим, це не означає, що міжнародний арбітраж в Україні може здійснюватись лише цими органами. Як зазначається в у п. 18 Постанови Пленуму Верховного Суду України № 12 від 24.12.1999 р. "Про практику розгляду судами клопотань про визнання й виконання рішень іноземних судів та арбітражів і про скасування рішень, постановлених у порядку міжнародного комерційного арбітражу на території України") "... поряд із ними це можуть здійснювати також спеціально створений для розгляду окремої справи арбітраж або постійно діюча поза системою судів загальної юрисдикції арбітражна установа, яким за угодою сторін передано вирішення: спорів із договірних та інших цивільно-правових відносин, що виникають при здійсненні зовнішньоторгових та інших видів міжнародних економічних зв'язків, якщо комерційне підприємство хоча б однієї зі сторін знаходиться не на території України; спорів створених на території України підприємств 3 іноземними інвестиціями і міжнародних об'єднань та організацій між собою або між їх учасниками, а так само їх спорів з іншими суб'єктами права в Україні". Отже, розгляд клопотань про скасування рішень міжнародного комерційного арбітражу, які є винятковим засобом оспорювання 
арбітражного рішення, буде здійснюватись судами відповідно до процесуальних норм, що містяться в гл. 1 Розділу VIII ЦПК України.

\section{Список літератури:}

1. Штефан М. И. Цивільне процесуальне право України: Академічний курс, підручник. К. : Ін Юре. 2005. 624 с.

2. Цивільний процес України. Академічний курс : підручник / за ред. С. Я. Фурси. К.: КНТ. 2009.- (Процесуальні науки).

3. Цивільне процесуальне право України : підручник. / за заг. ред. С. С. Бичкова. К. : Атіка, 2009.

4. Комаров В. В. Нотаріат в Україні : підручник / В. В. Комаров, В. В. Баранкова. Х. : Право. 2011. 


\title{
ПРАВОВЕ РЕГУЛЮВАННЯ ВІДНОСИН ІНТЕРНЕТ- ТРЕЙДИНГУ ДОСВІД РЕГУЛЮВАННЯ РИНКУ FОRЕХ
}

\author{
Миткаленна Аліна Юріївна \\ Студентка II курсу \\ Факультет права та міжнародних відносин \\ Київського університету імені Бориса Грінченко
}

\begin{abstract}
Хатнюк Наталія Сергіївна
Професор кафедри публічного та приватного права, д.ю.н.,доцент

Факультету права та міжнародних відносин Київського університету імені Бориса Грінченко
\end{abstract}

У сучасних реаліях Forex є одним із альтернативних способів інвестування через інтернет-трейдинг аб довічне утримання акцій.

Перші Forex-компанії з'явилися ще наприкінці 90-х років та пропонували клієнтам доступ до торгівлі валютою з великим «кредитним плечем». Проте навколо законодавчого регулювання їхньої діяльності досі точаться гострі дискусії, зокрема через відсутність чіткого розмежування діяльності українських Forex -компаній на ринку фінансових інструментів та реальному валютному ринку і банківської діяльності. Через відсутність регулятивної політики таких компаній «в тіні» на українському ринку Forex обертається більше 200 млн. дол. США.

Міжнародний валютний ринок форекс являє собою сукупність операцій- угод з обміну певної суми однієї валюти на іншу за узгодженим сторонами курсом із розрахунками на певну дату. Ринок форекс включає не лише угоди з купівлі та продажу однієї валюти за іншу з розрахунками як на дату здійснення операції, так і в інші часові інтервали (операції спот, валютні свопи, форвардні угоди тощо). На ринку форекс всі операції є безготівковими. Головними валютами, на частку яких припадає основний обсяг операцій на ринку форекс, сьогодні є долар США, євро, японська єна, швейцарський франк та британський фунт стерлінгів. [1] Фактично Форекс є сукупністю відносин з купівлі-продажу іноземної валюти для отримання прибутку від змін валютних курсів.

На сьогодні діяльність ринку Форекс в Україні загалом та інтернет-трейдинг зокрема врегульовані недостатнім чином. Незважаючи на наявність у низці нормативно-правових актів окремих положень, що регулюють дані відносини, залишається також чимало колізій та прогалин у чинному законодавстві. Це $\epsilon$ причиною багатьох правових ризиків, з якими стикаються потенційні інвестори. Також слід звернути увагу на малу кількість наукових досліджень у даній сфері. [2]

Контроль за проведенням валютних операцій в Україні здійснює Національний банк України, відповідно до Закону України «Про Національний банк України» та Постанови Правління Національного банку України «Про 
Інструкція порядок відкриття, використання, закриття рахунків у національній та іноземних валютах». Проте, вільного необмеженого проведення конвертаційних операцій законодавство нашої держави не передбачає. До недавнього часу не існувало і законодавчої основи для маржинальної торгівлі. Проте, Податковий кодекс України, що набув чинності 01.01.2011 p., використовує термін маржинального прибутку, проте без його визначення.

Через особливість валютного та податкового законодавства України такі компанії не мають юридичного права надавати фінансові послуги. Вони діють лише на основі букмекерської ліцензії, що не дає їм права надавати фінансові послуги. Більшість же великих дилінгових компаній взагалі мають іноземну реєстрацію тому, в свою чергу, місцеві представництва н несуть ніякої відповідальності перед користувачами на території знаходження філіалу. Тож, зазвичай клієнт такої компанії не має фактичної можливості захистити свої права в суді України.

Слід зазначити, що закордоном ситуація складається так само, тобто форексні компанії не підлягають прямому державному регулюванню. Торгівля на ньому відбувається за допомогою телефонів та Інтернету. Взагалі, реальної купівлі-продажу валюти тут не відбувається, то регулювати немає що. Водночас, відносини брокера з клієнтом чітко врегульовані законодавством в розвинених країнах.

В Україні навіть ці відносини не мають законного підгрунття i не регулюються чинним законодавством

Слід зазначити, що сама схема діяльності Форексу і його клієнтів не $\epsilon$ законодавчо врегульованою, а іноді - навіть тягне за собою порушення чинного законодавства України (зокрема, норм Цивільного кодексу України). Результатом цього $є$ те, що особи - громадяни України, які приймають рішення заробити на ринку Форекс, i тим самим вступають у відповідне правовідношення, в першу чергу, створюють небезпеку та загрозу для власних інтересів інвесторів. Оскільки у разі виникнення проблем, особа не зможе звернутися за захистом своїх порушених прав, або в разі такого звернення існує вірогідність того, що даній особі буде відмовлено у задоволенні ії вимог, адже сама особа за власним волевиявленнями надала свою згоду на участь в даній схемі роботи ринку Форекс. Причиною таких ситуацій, зазвичай, стає низька правова культура або іншими словами правовий нігілізм з боку громадян.

Тому необхідним вбачається створення відповідної нормативно-правової бази, яка б врегулювала діяльність даного ринку, або хоча б норм, які б безпосередньо врегульовували відносини між трейдером та інвестором. Що, в свою чергу, дало б більше можливостей інвестору захистити свої права у разі виникнення певних спорів. [3]

Розробка проект Закону України про діяльність форекс-компаній, який згодом було відхилено через недоопрацювання, зумовлена необхідністю впорядкування та правового забезпечення діяльності з надання послуг на ринку форекс. Необхідність прийняття поданого законопроекту зумовлена відсутністю регулювання і контролю в сфері надання послуг форекс-компаніями в Україні, 
що призводить до вимивання з української економіки десятків мільйонів доларів щорічно. Внаслідок відсутності законодавчого врегулювання діяльності форексдилерів держава Україна щорічно недоотримує значні грошові надходження до Державного та місцевих бюджетів, а споживчі форекс-послуг залишаються цілком незахищеними.

В той же час, так званий ринок Форекс в Україні останні роки зростає високими темпами та залучає кошти від широких верств населення. Доопрацьований проект Закону України про діяльність форекскомпаній підготовлено Комітетом 3 питань фінансової політики і банківської діяльності, виходячи з норми частини другої статті 110 Регламенту Верховної Ради України, за наслідками опрацювання двох альтернативних законопроектів: проекту Закону про діяльність форекс-дилерів (реєстр. N 3672 від 18.12.2015 р.), поданого народним депутатом України Рибалкою С. В., та проекту Закону про діяльність форекс-дилерів (реєстр. N 3672-1 від 29.12.2015 p.), поданого народними депутатами України Рудиком С. Я. та Опанасенком О. B.

Названими вище альтернативними законопроектами, по суті, передбачена спроба законодавчо легалізувати механізми діяльності на так званому ринку Форекс в Україні. Разом із тим, законопроекти, на жаль, не окреслюють економічної сутності діяльності форекс-компаній. Також існують певні розбіжності щодо недосконалого визначення регулятору ринку, щодо сфери застосування, взагалі щодо основної суті ринку Форекс тощо.

Разом із тим, необхідно наголосити на тому,що реальний стан речей на так званому ринку форекс в Україні, зокрема, діючі регламенти та процедури роботи компаній на цьому ринку, з усією відповідальністю дозволяють стверджувати, що усі (або майже усі) ці компанії діють за принципами, які багато у чому аналогічні діяльності букмекерських контор. Так звані форекс-ділери пропонують своїм клієнтам робити ставки на події, які пов'язані не 3 результатами, наприклад, спортивних змагань, як букмекери, а відповідно до певних чітких фінансових показників, насамперед, цін фінансових активів, у першу чергу, цін однієї валюти відносно іншої. [4]

Законопроектом запроваджуються правила i умови створення $\mathrm{i}$ функціонування компаній, які надають послуги на ринку Форекс в Україні, а а також, зокрема, передбачено визначення та застосування термінів, характерних для сфери Форекс, виходячи 3 концепції законопроекту, а саме: «форекспослуга», «форекс-угода», «форекс-подія», «форекс-система», «форекскомпанія», «клієнт форекс-компанії», ; чітко визначається сфера дії Закону, від якої відокремлюється діяльність на міжнародному міжбанківському валютному ринку (foreign exchange market); регулятором сфери Форекс пропонується, як зазначалось вище, Національна комісія, що здійснює державне регулювання у сфері ринків фінансових послуг, але у разі ії ліквідації, ці повноваження будуть передані Національному банку України, форекс-компаніям пропонується надати статус фінансових установ, принципи та засади функціонування саморегулятивної організації як неприбуткового об'єднання форекс-компаній; обов'язковість створення саморегулятивною організацією гарантійного фонду 
для захисту інтересів споживачів форекс-послуг тощо, а також внесення змін до законів України «Про фінансові послуги та державне регулювання ринків фінансових послуг», «Про запобігання та протидію легалізації (відмиванню) доходів, одержаних злочинним шляхом, фінансуванню тероризму та фінансуванню розповсюдження зброї масового знищення», «Про заборону грального бізнесу в Україні», «Про ліцензування видів господарської діяльності» з метою захисту прав споживачів у сфері форекс-послуг. [4 ]

Наостанок, слід наголосити на тому, що ефективне використання громадянами України інструментів ринку Форекс як альтернативного способу інвестування можливе лише за умови достатньої обізнаності щодо усіх ризиків даного виду діяльності (в тому числі, правових), і , як наслідок, запобігання їх виникненню.

\section{Список використаних джерел}

1. Офіс з фінансового та економічного аналізу у Верховній Раді України: « Міжнародний досвід регулювання ринку форекс», 2017

2. В.В Голубчік. Проблемні питання діяльності ринку форекс в Україні (правові аспекти): тези. Київський національний торгівльно-економічний університет, 2012.

3. 3. Леонов Ю., Дроздова Н. Довічне управління фінансовими активами // Режим доступу: http:/jurliga.ligazakon.ua/news/2011/10/24/50721.htm

4.4. Пояснювальна записка до Проєкту Закону України «Про діяльність форекс-компаній» від 08.09.2017 № 3672-д 


\title{
ДОВЕДЕННЯ ДО САМОГУБСТВА: ПРОБЛЕМИ КРИМІНАЛЬНО-ПРАВОВОГО РЕГУЛЮВАННЯ
}

\author{
Савліва Наталія Олександрівна
}

здобувач вищої освіти

\begin{abstract}
Науковий керівник :
Майстро Діана Михайлівна,

асистент кафедри кримінального права і процесу

Юридичного факультету Національного авіаційного університету
\end{abstract}

У сучасному світі самогубство $€$ надзвичайно гострою соціальною проблемою. На жаль, саме самогубство стає однією з найпоширеніших причин смерті серед молодих людей. Це викликано багатьма факторами, зокрема глибокою депресією, хронічним стресом та іншими складними психічними розладами здоров'я, фінансовими проблемами, розривом відносин або тяжкою хворобою тощо.

Злочин, передбачений в диспозиції ст. 120 Кримінального кодексу України (далі - КК України) встановлює кримінальну відповідальність за доведення особи до самогубства.

Відповідно до чинного кримінального законодавства доведення до самогубства або до замаху на самогубство є наслідком жорстокого поводження 3 людиною, шантажу, систематичного приниження іiі людської гідності або систематичного протиправного примусу до дій, що суперечать іiї волі, схиляння до самогубства, а також інших дій, що сприяють вчиненню самогубства [1].

Тобто доведення до самогубства вчиняється шляхом вчинення активних дій. Зокрема, Постанова Пленуму Верховного Суду №2 від 07.02.2003 року «Про судову практику в справах про злочини проти життя та здоров'я особи» під жорстоким поводженням слід розуміти безжалісні, грубі діяння, які завдають потерпілому фізичних чи психічних страждань (мордування, систематичне заподіяння тілесних ушкоджень чи побоїв, позбавлення їжі, води, одягу, житла тощо). Систематичним приниженням людської гідності є тривале принизливе ставлення до потерпілого (постійні образи, глумління над ним тощо) [2].

Згідно КК України за доведення до самогубства особа підлягає відповідальності у виді обмеження волі на строк до трьох років або позбавлення волі на той самий строк. Кваліфікуючою ознакою цього злочину є вчинення його щодо особи, яка перебувала в матеріальній або іншій залежності від винуватого, або щодо двох або більше осіб, карається обмеженням волі на строк до п'яти років або позбавленням волі на той самий строк. Особливо кваліфікуюча ознака - вчинення діяння, передбачене частинами першою або другою цієї статті, якщо воно було вчинене щодо неповнолітнього, карається позбавленням волі на строк від семи до десяти років [1].

Варто наголосити, що значна кількість кримінальних проваджень за ст. 120 КК України, зареєстрованих у поліції, навіть не доходять для розгляду у суд. 
Причинами ускладнення проведення слідства є відсутність доказів, а також складу кримінального правопорушення або суб'єкта.

Проблема стає більш критичною, адже сьогодні з'явились й інші, не передбачені кримінальною нормою способи доведення до самогубства, серед яких створення «груп смерті» у соціальних мережах Інтернет, діяльність яких спрямована на доведення до самогубства підлітків. Саме віртуальне середовище $\epsilon$ платформою психологічного маніпулювання молодими людьми. Ще у 2016 році «популярною» стала гра «Синій кит», учасники якої вчиняли суїцид або завдавали собі різні тілесні ушкодження. На жаль, у 2021 році ця проблема знову стала актуальною.

Тобто, у структурі механізму доведення до самогубства необхідно зазначити про потужну силу новітніх технологій. Злочинці користуються різноманітними методами впливу на психіку неповнолітніх, а саме: анонімні погрози, наклепи, публічне викриття, шахрайство тощо.

Головними особливостями кримінальних правопорушень, які здійснюються через Інтернет 3 метою доведення дітей до самогубства є: відсутність реального контакту представника спільноти 3 потерпілим, ускладнений процес встановлення особи злочинця, відсутність у кримінальному законі норми, що конкретизувала б визначення таких дій кримінальнопротиправними.

Отже, державі слід приділити особливу увагу саме тим кримінальним правопорушенням, які пов'язані із доведенням до самогубства, адже кількість випадків суїциду суттєво зростає.

Протидіяти масовим самогубствам можна за допомогою певного комплексу ефективних дій, а саме це: створення та популяризація системи центрів та служб психологічної допомоги та реабілітації; обмеження поширення контенту насильства у засобах масової інформації; забезпечення дієвого механізму реагування правоохоронних органів на кримінальні правопорушення, пов'язані з доведенням до самогубства; доповнення законодавства спеціальними нормами для боротьби з кібербулінгом [3, с. 50].

Тобто, самогубство потребує особливої уваги як на всесвітньому, так і на національному рівні. Зокрема, кіберполіція повинна спрямовувати свою діяльність на пошук ефективних інструментів щодо запобігання поширенню кібербулінгу та притягувати винних до відповідальності. Також надзвичайно важливим є встановлення емоційного зв’язку між батьками та дітьми, їхня увага і живе спілкування.

\section{Список літератури}

1. Кримінальний кодекс України: Закон України від 05.04 .2001 р. №2341-III. URL: https://zakon.rada.gov.ua/laws/show/2341-14/conv\#n779

2. Про судову практику в справах про злочини проти життя та здоров'я особи: Постанова Пленуму Верховного Суду України № 2 від 07.02.2003 p. URL: https://zakon.rada.gov.ua/laws/show/v0002700-03\#Text

3. Сергій Мінченко. Доведення до самогубства: кримінологічний вимір соціальної обумовленості заборони». Науковий часопис Національної академії прокуратури Украӥни. Київ. 2019. № 1. С. 42-52. 


\title{
ПЕРЕХІД ТРУДОВОГО ДОГОВОРУ В ЦИФРОВУ ПЛОЩИНУ
}

\author{
Судак Ірина Михайлівна, \\ старший викладач \\ кафедри «Право» \\ Івано-Франківська філія ЗВО «Відкритий міжнародний \\ університет розвитку людини «Україна»»

\section{Попова Діана Анатоліївна,} \\ студентка 4 курсу \\ спеціальності «Право» \\ Івано-Франківська філія ЗВО «Відкритий міжнародний \\ університет розвитку людини «Україна»»»
}

У зв'язку із швидким переходом світу в цифрову площину виникають нові завдання: в тому числі і перед фахівцями трудового права.

Час не стоїть на місці, а разом з ним не стоять на місці і нові технології, які в свою чергу дають поштовх розвитку нормативної бази, зокрема і в галузі трудового права. Даний факт обумовлений як технічним прогресом, змінами в економіці так і чинниками, які змушують по тим чи іншим причинам працівників і роботодавців переходити на дистанційну форму зайнятості. [ 1 ]

На жаль існуючі форми і види трудових договорів не можуть задовольнити всі потреби сучасного світу. У зв'язку з цим суб'єкти господарювання шукають найбільш раціональні в умовах технократної економіки форми закріплення трудових відносин. [2]

3 цього виникає необхідність вивчення світової практики з питань трудових договорів та інтеграції вдалого досвіду в відчизняну систему трудового законодавства [3]

Для вирішення завдання модернізації трудових договорів слід застосовувати технології, які вже продемонстрували свою ефективність на практиці і сумісні 3 галуззю: трудове право. [4]

На думку вчених доречне застосування такої технології як Блокчейн.

Для найбільш глибокого розуміння цієї технології слід звернутися до значення іiï назви block (блок) i chain (ланцюг), тобто пов'язані в певні кола блоки інформації.

Блокчейн-розподілена база даних, що зберігає упорядкований ланцюжок записів, постійно подовжується. Дані захищені від підробки і перекручування Кожен блок містить тимчасову позначку, хеш попереднього блоку і дані транзакцій, представлені як хеш-дерево. Таку розподілену базу даних закладено в основу криптовалюти Bitcoin (вона була описана 2008 і реалізована 2009 року), де служить бухгалтерською книгою для всіх операцій. Таку базу називають Блокчейн. [6] 
Система Блокчейн створить найбільш прозорі трудові відносини, оскільки інститут трудового договору буде змінений на смарт-контракт.

Смарт-контракт ця угода, яка передбачає суворе і чітке формулювання умов, автоматизацію процесів і мінімізацію залучення довірених осіб. [5]

Важливою умовою для створення i використання смарт-контрактів $\epsilon$ наявність наступних елементів: по-перше, це цифрова ідентифікація всіх сторін договору; по-друге, для створення смарт контракту необхідно де централізоване середовище, здатне зберігати дані в блоках; по-трете, предмет договору та необхідні для виконання зобов'язання інструменти; по-четверте, це конкретно описані умови виконання, що підтверджують обидві сторони. [7]

Смарт-контракти відрізняються наступними перевагами: автономність, надійність, швидкість, економія.

Кількість змінних, таких як стаж, кваліфікація, обсяг виконаної роботи і інші обмежуватиметься тільки потужністю мережі і фантазією автора. Що дозволить позбутися трудової книжки як рудемента.

Отже, смарт-контракт $\epsilon$ найбільш гармонійним варіантом оскільки в алгоритмі можна буде прописати як обсяг виконаної роботи так і винагороду. Що в подальшому захистить обидві сторони трудового договору. Застосування данної технологія дозволить отримувати інформацію як про працівників так і про роботодавців, унеможливить протиправну зміну умов договору або укладення його $з$ порушеннями законодавства.

\section{СПИСОК ЛІТЕРАТУРИ}

1. Кодекс законів про працю України документ 322-08, - 1053-IX.

2. Болотіна Н.Б. Трудовий договір за законодавством України: Навч. посібник. - К.: Вид-во А.В. Паливода, 2008 - 124 с.

3. Лазор В. Щодо відмітних ознак трудового договору // Право України. 2010. - №18. - 280 c.

4. Тубелець I. Порядок укладення трудового договору (контракту) // Праця і зарплата. - 2009. - № 18. - 128 с.

5. Чанишева Г. Значення правильного оформлення трудового договору. // Право України. - 2012 - №17. - 236 с.

6. https://uk.m.wikipedia.org/wiki/Блокчейн.

7. https://legalhub.online/analityka/yak-blokchejn-zminyuye-yurysprudentsiyuoglyad-5-najtsikavishyh-ligalteh-proektiv/amp. 


\title{
SCIENTIFIC APPROACHES TO UNDERSTANDING OF PRODUCT COMPETITIVENESS MANAGEMENT SYSTEM
}

\author{
Senyshyn Oksana
}

Doctor of Economic Science, Professor, Ivan Franko National University of Lviv

Diversity of interpretation of the terms pertaining to the theoretical problems of competitiveness and competitiveness management system demonstrates the situation of disarray of the conceptual construct in this sphere of knowledge. It is characterized both, by the variety of definitions, and by their inadequacy, which complicates the study of economic problems of competition and product competitiveness.

Of great importance in the study of theoretical and methodological principles of product competitiveness management is the issue of diversity of approaches to this concept [1] examine a range of approaches to competitiveness management: systemic; logical; reproductive-evolutionary; innovative; complex; global; integrative; virtual; standardized; marketing; exclusive; functional; process; structural; situational (variational); normative; optimization; top-down (administrative); behavioral; business. A detailed analysis of scientific sources on the theoretical-methodological and applied principles of competitiveness management allowed the author to group scientific approaches to it into two groups:

1) classical approaches, among them process, systemic, synergetic, situational, structural, functional, reproductive-evolutionary, top-down, behavioral, complex, etc.;

2) specific approaches - logical, marketing, innovative, global, integrative, normative, logistical, exclusive, virtual, optimization- business, approach based on the concept of «food safety», etc.

Let us present a detailed description of some of the above said approaches.

Process approach to competitiveness management, that to some extent is a part of the systemic approach, is understood to mean orientation of an enterprise towards business processes, and the management systems are directed at managing both, each business process separately and all business processes.

The process of product competitiveness management proper in accordance with the process approach is a chain of uninterrupted interdependent activities in strategic marketing, planning, organization of processes, accounting and control, motivation, regulation. Coordination of the works is central and begins with the strategic marketing management [1]. It should be noted that the process concept in the study of general management considers marketing as a special, not a general function. Thus, particularities of this approach to product competitiveness management become evident. 
Through the prism of the process approach strategic marketing is a complex of works predicting competitiveness standards on the basis of strategic market segmentation, prediction of product values aiming at maintaining or achieving competitive advantages of the enterprise and stable deriving of a sufficient profit. Product competitiveness standards materialize in the sphere of production, and are realized through deriving a profit at the stage of tactical marketing as a complex of works in the tactical market segmentation, advertising and sales promotion [1].

Systemic approach is typical of numerous management and economic phenomena.

Here an organization is regarded as an open system, that is a totality of such interdependent elements as people, structures, tasks and technologies oriented towards achievement of the organization's goals in a changing external environment [6]. Accordingly, systematic approach to competitiveness management involves complex management of competitiveness factors in order to achieve a synergetic effect.

Synergetic approach should be considered as the development of the systemic approach to complex management systems [6]. According to scientists-economists, taking into account synergetic regularities allows to substitute the traditional ideas about management, according to which the effect of administrative influence managerial influence conclusively and linearly depends on the strength of efforts. From the standpoint of administrative activity, the most important and useful can be the following regularities of their development: it is expedient to carry on development of complex enterprises on the basis of identification of their own trends of development and using the latter for the achievement of the set goals; in the periods of instability, even minor administrative influences can produce a considerable effect on the development of the entire enterprise.

Situational approach emerged as the answer to the question: what of the variables of the organization or its environment is important or especially important? [3]. Under this approach, there is no single, best of all, method to manage competitiveness of an enterprise or its products. The variety of factors both, at the enterprise and in the environment shows to the effect of the «law of the situation». That is, the art of the situational approach to competitiveness management is finding the most important variables in a given specific situation and to choose, develop methods whose application would a have an impact on the effectiveness of achieving the goals of the enterprise.

Structural approach to the problems of product competitiveness management means determination of importance, priorities among the factors, methods, principles and other instruments in their totality for the purpose of establishing rationality of the ratio and feasibility of the resources [4]. Structuring gives the opportunity to identify the most important factors for the product competitiveness and its elements and, with the optimal use of such data, to enhance competitiveness of the enterprise.

Implication of the functional approach is that the need for a competitive commodity is seen as a totality of functions that must be performed to satisfy such need. Once the functions have been identified, several alternative objects are created to perform these functions, and the one of them is selected, that requires the minimal total cost of the object's life cycle per unit of its useful effect. This approach is the brainchild functional-cost analysis. 
Reflective approach to management of the enterprise competitiveness envisages a target-oriented organization of reflective influences aimed the object of management in order to improve the competitive standing of the enterprise in the market, particularly, its products [5].

Reproducing-evolutionary approach oriented towards resumption of manufacture of the product to satisfy the demand of a specific market with lower total expenditures per unit of useful effect. Each new model must be better than the replaced model [1]. This approach, at the first glance, is quite simple, since in this case the existing manufacturing and technological capabilities of enterprises are used. However, a deeper analysis gives the opportunity to become aware of the complexity and effectiveness of this approach to management.

Theoretical and methodological essence of the top-down approach envisages regulation of the functions, rights, obligations, quality standards, expenditures, duration, elements of the product competiveness management system through normative acts (orders, resolutions, instructions, standards, prescriptions, plans, programs, regulations, procedures, etc.).

Complex approach is interpreted as taking simultaneously into consideration various aspects of product competitiveness management: technical, environmental, economic, organizational, social, psychological, demographic, etc. aspects.

Let us now consider specific approaches to product competitiveness management.

Thus, the substance of the logical approach to competitiveness management lies in application of the principles of dialectic logic: principle of objectivity of the object assessment; principle of multifaceted object assessment; principle of historicism, etc. by applying this approach, where feasible, it is possible to use further on an innovative approach. According to the interpretation proposed by P.A. Fathutdinov and G.V. Osovska [1], it may be concluded that this approach is not applied to a separate product or an enterprise, but to the innovative orientation of economy of an individual country in general.

Marketing approach involves orientation of the managing subsystem when solving any tasks for external and internal consumers. Marketing management envisages actions that include analysis, planning, implementation and control of measures aimed at formation and stimulation of the demand for goods or services and an increased profit [2].

Important for the study of the problem of product competitiveness management is also the global approach, typical of the transnational companies, for it is based on consideration of competitive advantages not as an internal element, but as a global (international) phenomenon, whose management has to be a supersystem.

Rather popular in the present day environment is the integrative approach to competitiveness management. This approach is based on strengthening cooperation of the management subjects and focuses on the study and strengthening of their interrelationship [1]:

- between individual subsystems and components of competitiveness of the enterprise; 
- between stages of the product life cycle (strategic marketing, scientific research and development, organizational and technological preparation of production, manufacture, etc.);

- horizontal interrelationship between the management subjects.

The substance of the exclusive approach to competitiveness management lies in acquiring by the enterprise of the exclusive right to use an innovation in any sphere of activity or a competitive advantage. In other words, the content of this approach lies in the creation of durable competitive advantages by way of know-how and innovations acquisition in various spheres of management.

Development of modern information technologies, advent of mobile offices and technoparks, the use of the Internet has made it possible to develop such an approach to competitiveness management as the virtual approach. This approach envisages formation of virtual organizational structures, acquisition, processing, use and transfer of information to meet relevant needs with the possibility, to act not only on the local level, but compete on the global scale without direct contacts with clients and partners, virtually covering the longest distances.

The study of product competitiveness management requires also the use of the optimization approach as well. It involves transfer from qualitative to quantitative estimates with the aid of operation research methods, engineering calculations, statistical methods, expert assessments, etc. optimization approach is realized through the establishment of dependence between technical-organizational and economic indices, study of the mechanisms of action of the law of scale and the law of economy of time, the laws of economic interrelationship of the costs in production and consumption spheres, dependence between the quality of the product and costs of its production, etc.

One of the approaches to the assessment of competitiveness of agri-food products is our proposed approach based on the concept of «food safety» [7], that unlike the existing classical and specific approaches involves not only taking into account economic, organizational, innovative and other competitive advantages of a specific product, but also formation of the system of quantitative and qualitative indices, whose observance will ensure both, economic and food safety, since it is a question of competitiveness of food products.

In accordance with the foregoing, production of agri-food products must be made taking into account the safety factors on the level of the enterprise, the country and the international market. Unfortunately, today Ukraine is not yet sufficiently oriented towards the «secure» food products competitiveness in the sphere of food production. It should be borne in mind that the active economic activity of the enterprise, interaction with the environment, change the situation in the market that, in its turn, lays the enterprise under the obligation to adapt to changes.

\section{References:}

1. Fatkhutdinov, R.A., Osovsjka, Gh.V. (2009). Organization competitiveness management. - Kyjiv: Kondor. 470 p.

2. Gharkavenko, S.S. (2006). Marketing. - Kyjiv: Libra. 720 p. 
3. Kredisov, A.I. (2001). History of management studies. - Kyjiv: Znannja Ukrajiny. $300 \mathrm{p}$.

4. Lepejko, T.I., Kotlyk, A.V. (2012). Process approach to enterprise competitiveness management. - Kharkiv: Vyd. KhNEU. 316 p.

5. Mal'chik, M.V. (2010). Reflexive management of the competitiveness of industrial enterprises. - Donetsk. 304 p.

6. Mullakhmetov, Kh.Sh. (2011). Modern approaches and concepts in the practice of enterprise management // Management in Russia and Abroad. No. 6: 76-82.

7. Senyshyn, O., Kundytskyj, O., Klepanchuk, O. (2019). An index analysis for the assessment of the competitiveness of food products in Ukraine // Journal of Competitiveness: scientific periodical journal. Issue 11(2). - Czech Republic: Tomas Bata University in Zlin Centre: 130-143. - https://doi.org/10.7441/joc.2019.02.09. 


\title{
PROBLEME DER DIAGNOSE, BEHANDLUNG UND PRÄVENTION URINÄRE DIATHESE
}

\author{
Barannyk Serhiy \\ Professor der Abteilung für Allgemeine Chirurgie \\ Dnipropetrovsk Medical Academy des Gesundheitsministeriums \\ der Ukraine
}

Barannik Constantine Kandidat der medizinischen Wissenschaften, Assistent der Abteilung für Chirurgie №1 Dnipropetrovsk Medical Academy des Gesundheitsministeriums der Ukraine

Shevtsov Vadim der Chirurg Dnjepr Clinical Association of Ambulance Dnipro, Ukraine

Die gesamte materielle Welt um uns herum besteht aus geordneten und chaotisch angeordneten Molekülen verschiedener Elemente. Die ersten werden durch kristalline Substanzen dargestellt, von denen die meisten in der Natur liegen, die zweiten amorph. Mineralisierung in Wildtieren ist weit verbreitet. Es trägt entweder eine physiologische Funktionsbelastung oder kann ein Zeichen für einen pathologischen Prozess im Körper sein. Die Ausscheidung von Salzkristallen im Urin ist eine häufige Sache. Die Nieren, die die Funktion der Körperreinigung erfüllen, entfernen überschüssige Salze, die mit der Nahrung in den Körper gelangen. Ihre Natur hängt direkt von den Produkten ab, die wir konsumieren. Mensch und Umwelt sind ein einziges Ökosystem. Und die geringste Änderung des Austauschs zwischen ihnen sofort oder im Laufe der Zeit wird unweigerlich zu einem Ungleichgewicht führen. Die Bildung mineralorganischer Strukturen aufgrund der Verletzung der Homöostase zwischen Kolloiden und kristallbildenden Substanzen trägt nicht zur Funktionsstabilität des Organismus bei und führt zu pathologischen Manifestationen. Eine davon ist die Urolithiasis. Eine signifikante Ausscheidung von monotonen Salzen wird jedoch manchmal von Ärzten diagnostiziert: Harndiathese, deren Kompetenz bisher nicht nachgewiesen wurde, da bestimmte nosologische Einheiten nicht erfüllt werden können. Zuallererst bedeutet Diathese "Veranlagung" für jeden pathologischen Zustand, der zu einer Krankheit führen kann. Die Harndiathese spiegelt den Zustand der Nieren, Gelenke und anderer innerer Organe wider.

Die Harndiathese wird oft als Synonym für die neuroarthritische Diathese angesehen, die eine der Varianten der konstitutionellen Anomalie darstellt. In diesem 
Fall charakterisiert die "Konstitution" die Menge der morphologischen und funktionellen Eigenschaften des Körpers des Kindes, die die individuellen Eigenschaften seiner Reaktivität bestimmen. Diathese oder eine Anomalie der Konstitution charakterisiert die Merkmale einer bestimmten Art von Stoffwechsel, die unter bestimmten Bedingungen in der Pathologie realisiert werden sollten.

Heute wird angenommen, dass die Salzdiathese ein Zustand des Körpers aufgrund einer erblichen Veranlagung ist, die durch eine erhöhte Salzbildung und infolgedessen die Anreicherung in den Nierenbeckensteinen (Steinen) verschiedener Größen und Ursprünge gekennzeichnet ist: Calciumoxalate, Urate, Carbonate, Phosphate und auch deren Kombination. Es ist auch ein Zustand, bei dem die sogenannten echopositiven Einschlüsse im Nierenbecken während der Ultraschalluntersuchung festgestellt werden. Das Vorhandensein von sogenanntem Harnsand kann von einer Entzündung der Harnwege, der Freisetzung erhöhter Salzmengen im Urin und dem Vorhandensein von Dysurie begleitet sein. Salzdiathese kann auch bei Säuglingen als Erbkrankheit diagnostiziert werden. In der Praxis sind solche Fälle jedoch recht selten, da sich die meisten Salzdiathesen in einem ziemlich reifen Alter manifestieren. Es ist nicht zu beachten, dass bei den meisten Menschen die Anzeichen einer Salzdiathese ab dem 20. Lebensjahr durch Ultraschall der Nieren bestimmt werden können.

Heute ist es mit Hilfe der Ultraschalluntersuchung des Harnsystems möglich, die Anzeichen einer Salzdiathese bis zu ihren ausgeprägten klinischen Manifestationen zu bestimmen. Wir sollten jedoch nicht vergessen, dass die Salzdiathese nicht auf die Nierenpathologie beschränkt ist. Die Gründe für die Bildung von echopositiven Einschlüssen, die durch Ultraschall im Becken der Nieren bestimmt werden, sind vielfältig. Die Salzdiathese ist eine Folge einer Reihe von Störungen des Harnstoffstoffwechsels im menschlichen Körper. Daher sollten diese Patienten sorgfältig untersucht werden, um die Ursachen für übermäßige Harnsalze zu ermitteln.

Es ist $\mathrm{zu}$ beachten, dass echopositive Einschlüsse, die während der Ultraschalluntersuchung im Nierenparenchym bestimmt werden, nicht immer eine fokale Salzansammlung im Nierenbecken darstellen. Dies kann den diagnostischen Prozess erheblich erschweren, insbesondere bei Erwachsenen und älteren Menschen. Echopositive Schatten treten nicht nur als Folge von pathologischen Veränderungen im Stoffwechsel auf, sondern auch als Folge von morphologischen Veränderungen im Parenchym, die aufgrund des Alters oder pathologischer Veränderungen in den Gefäßen des Parenchyms (Atherosklerose) oder im Parenchym unter dem Einfluss von auftreten schädliche Faktoren (Nephrosklerose, Salzansammlung) im Bindegewebe usw.).

Für die Differentialdiagnose der Salzansammlung im Nierenbecken und anderer echopositiver Einschlüsse im Parenchym verwenden wir die folgende Methode. Bei der ersten Bestimmung während der Ultraschalluntersuchung von echopositiven Schatten ohne klinische Anzeichen einer Salzdiathese verschreiben wir eine litholytische Therapie mit Phytopräparaten oder offiziellen Phytokollektionen (Phytoteas) mit litholytischer Wirkung und erhöhen den Wasserverbrauch (wenn der Patient 3 Monate lang keine Kontraindikationen hat). Danach führen wir eine KontrollUltraschalluntersuchung der Nieren durch, wobei die erhaltenen Daten mit den vorherigen verglichen werden. Unter Bedingungen der Salzdiathese sollten sich 
Anzahl und Größe der echopositiven Einschlüsse von den vorherigen Werten unterscheiden. Die Methode wird bei 48 Patienten angewendet. Das Vorhandensein einer Salzdiathese wurde bei 15 Personen bestätigt.

Aufgrund der Tatsache, dass Diathese keine Krankheit ist, sondern nur bestimmte Merkmale von Stoffwechselprozessen bestimmt, beziehen sich die Behandlungsmaßnahmen in erster Linie auf eine Reihe von Maßnahmen zur Verhinderung und Verhinderung der Entwicklung einer möglichen Pathologie.

Die Behandlung der Salzdiathese hängt in erster Linie von der Größe der Ansammlungen und den Eigenschaften der Salze ab, die einen Organismus verlassen. Eine konservative oder medizinische Behandlung besteht darin, Diuretika einzunehmen, um die Ansammlung von Sand in den Nieren zu stoppen. Die zweite Gruppe von Medikamenten stimuliert die Sandspaltung. Die Behandlung wird auch durch entzündungshemmende Medikamente ergänzt, da der Sand, der aus den Harnwegen austritt, Verletzungen und Entzündungen verursachen kann.

Wenn die Ursache der Diathese eine genetische Tubulopathie oder ein erworbener Defekt der Nierentubuli ist, werden diese Störungen nicht korrigiert. Daher sind bei der Salzdiathese die Ernährung und das Wasserregime von vorrangiger Bedeutung. Jeder Patient, der Veränderungen in der Urinanalyse und echopositive Einschlüsse im Nierenbecken festgestellt hat, sollte darauf achten, täglich mindestens 2 bis 2,5 Liter Flüssigkeit zu sich zu nehmen (sofern dies nicht durch das Herz-Kreislauf-System kontraindiziert ist). In heißen Klimazonen sollte diese Menge entsprechend den tatsächlichen Bedürfnissen des Körpers erhöht werden.

Weitere Empfehlungen hängen von der Art der Salze ab, die im Urin nachgewiesen werden und den Kliniker veranlasst haben, eine Salzdiathese zu diagnostizieren. Die Ernährung in Gegenwart einer signifikanten Menge an Oxalaten erfordert die Eliminierung von oxalsäurereichen Lebensmitteln (Rhabarber, Feigen, Sauerampfer, Tomaten, Spinat) aus der Ernährung, und eine Erhöhung des Uratspiegels verringert den Verzehr von Fleisch, Innereien, Bohnen und Schokolade, Kaffee und Kakao.

Es ist zu beachten, dass einige organische Salze über das hepatobiliäre System in das Darmlumen ausgeschieden und dann wieder in das Blut aufgenommen werden. Um diesen Kreislauf zu durchbrechen, werden bei der Behandlung der Salzdiathese Enterosorbentien verschrieben, die toxische Bestandteile absorbieren und aus dem Körper entfernen.

Das Behandlungsschema der Salzdiathese umfasst jedoch auch Kräutermedizin (verschreibungspflichtige Kräutermedikamente mit milder harntreibender Wirkung) und Diuretika. Die Sammlung von Heilkräutern und Arzneimitteln mit harntreibender Wirkung sollte von einem Arzt verschrieben werden.

Das heißt, die erste Richtung der Behandlung der Salzdiathese ist die Korrektur der Diät, die Verwendung einer individuellen Diät gemäß der Zusammensetzung der im Urin ausgeschiedenen Salze. Dies ist der einfachste, aber gleichzeitig schwierigste Weg bei der rationalen Behandlung der Salzdiathese: Die gezielte Aktion sollte konstant und regelmäßig sein.

Die zweite Richtung der Behandlung der Salzdiathese ist eine rationale und angemessene Auswahl von Behandlungsmaßnahmen, um die Fähigkeit der Nieren zu 
verbessern, das Blut zu reinigen, den Körper zu reinigen und verschiedene Salze im Urin auszuscheiden.

\section{Referenzenliste:}

1. Баранник С.I., Бараннік А.С., Терент`єва Г.А., Гречко Л.В. Проблеми комплексного лікування i профілактики сечового діатезу. Південноукраїнський медичний науковий журнал. 2016. №13(13) січень. С. 2931.

2. Баранник С.I., Бараннік А.С. Комплексне лікування і профілактика сечового діатезу. Урологія. 2018. T. 22, № 3(86). С. 154-156

3. Ривкин А.М. Мочекислый диатез - всегда ли это проявление нарушенного пуринового обмена? Здоровье мужчины. 2011. №3. С. 14-16.

4. Сергеев Ю.С. Конституция человека, конституциональные типы, аномалии конституции и диатезы у детей. Педиатрия. 2005. №5. С. 67-71.

5. Шабалов Н.П. Диатезы и аномалии конституции как педиатрическая проблема. Педиатрия. 2005. №5. С. 72-76. 


\title{
BIOCHEMICAL MARKERS OF THE SERIOUSNESS OF HYPOXIC-ISCHEMIC CNS DAMAGE IN NEWBORN
}

\author{
Posternak Hennadii \\ $\mathrm{MD}, \mathrm{PhD}$, \\ Professor of Bogomolets national medical university \\ Kyiv, Ukraine \\ Krivoruchko Maria \\ $\mathrm{PhD}$, Doctor of family medicine \\ Rubizhne, Ukraine \\ Posternak Dmytro \\ anesthesiologist \\ Poltava, Ukraine
}

In recent decades, one of the leading places in the structure of morbidity, disability and mortality of newborns has traditionally been perinatal hypoxic lesions of the CNS $[1,2,3]$. At the same time pathological changes occur in many organs and organ systems, including the hemostasis system [4,5]. The risk of hemostasis is due to the peculiarity of the condition and the functioning of the hemostasis system in newborns [6].

Goal. One of the promising areas for diagnosing the severity of brain damage in newborns is to determine biochemical markers of damage to the nervous system and the corresponding indicators of hemostasis.

Materials and methods. We studied circulating DNA fragments, annexin V, endothelin-1, circulating endothelial cells, as well as the main hemostatic parameters of coagulation, anticoagulation and fibrinolysis systems in full-term infants with moderate to severe perinatal hypoxic lesions of the CNS. The gestational age of patients ranged from 36 to 41 weeks.

\section{Conclusions.}

The concentration of Annexin V, the level of circulating DNA and DNA fragmentation in the lymphocytes in the serum of newborns with moderate and severe perinatal ischemia increased at all stages of the study. The indicators of desquamated endothelium and endothelin-I exceeded the data of healthy children from 5 to 7 times. The obtained data could indicate a deep disturbance of cerebral circulation and the formation of endothelial dysfunction. Endothelial damage stimulates excessive activation of coagulation factors. The level of thrombin-antithrombin complex, Ddimer and fibrin degradation products increases with subsequent consumption of anticoagulants. At the same time there is a decrease in antithrombin against thrombocytopenia. 


\section{Areas of prevention:}

1. Indicators of circulating DNA fragments in the blood, Annexin V may be the classification criteria for the severity of hypoxic-ischemic brain damage in full-term infants.

2. Indicators of endothelial dysfunction of the vascular system of the brain of newborns - endothelin-1, circulating endothelial cells can be not only diagnostic criteria for cerebral ischemia, but also reliable indicators of the formation of hypoxicischemic encephalopathy in newborns.

3. In full-term infants with perinatal hypoxic lesions of the CNS there is a high risk of developing DIC syndrome with clinical manifestations of thrombosis and bleeding.

4. Early diagnosis of disorders in the hemostasis system will prevent the development of coagulopathies, the formation of multiple organ failure and reduce the mortality from hypoxia in newborns.

\section{References:}

1.Bauman M.E., Cheung P.Y., Massicotte M.P. Hemostasis and platelet dysfunction in asphyxiated neonates. J Pediatr. 2011 Feb;158(2 Suppl):e35-9. Cornette and Levene, 2008.

2. Chen C.Y., Sun W.Z., Kang K.H. et al. Hypoxic preconditioning suppresses glial activation and neuroinflammation in neonatal brain insults. Mediators of Inflammation. 2015. 2015. 632592. DOI: 10.1155/2015/632592. PMID: 26273140. PMCID: PMC4530271.

3.Donn S.M., Chiswick M.L., Fanaroff J.M. Medico-legal implications of hypoxicischemic birth injury. Semin Fetal Neonatal Med. 2014; 19 (5): 317-321.

4. Kaffashian S., Tzourio C., Zhu Y.C., Mazoyer B., Debette S. Differential Effect of White-Matter Lesions and Covert Brain Infarcts on the Risk of Ischemic Stroke and Intracerebral Hemorrhage. Stroke. 2016. 47(7). 1923-5 https://doi.org/10.1161/STROKEAHA.116.012734.

5. Oswyn G., Vince J.D., Friesen H. Perinatal asphyxia at Port Moresby General Hospital: a study of incidence, risk factors and outcome. P N G Med J 2000;43:110 120.

6. Lv H., Wang Q., Wu S. et al. Neonatal hypoxic ischemic encephalopathy-related biomarkers in serum and cerebrospinal fluid. Clin. Chim. Acta. 2015 Oct. 23(450). 282-297. DOI: 10.1016/j.cca.2015.08.021. PMID: 26320853. 


\title{
AGE STRUCTURE OF HIV INFECTED PEOPLE MORTALITY IN MINSK
}

\author{
Shylava Marharyta, \\ Senior Lecturer of the Department of Epidemiology \\ Belarusian State Medical University \\ Dotsenko Marina \\ MD, Ph.D., Professor \\ Belarusian State Medical University \\ Valchuk Irina \\ Ph.D., Associate Professor \\ Belarusian State Medical University
}

Introduction. The HIV infection spread and its development to the terminal stages is a problem for countries around the world, especially for the countries of the Eastern Europe and Central Asia (EECA) region, where the number of people newly diagnosed with HIV has increased by $29 \%$, and the vast majority them (84\%) lived in Russia and Ukraine. The prevalence rate in the EECA region in 2018 was 9.0\% (CI 95\% 8.2-9.5) $[1,2]$.

The estimated number of people who died from AIDS-related causes in 2018 was 38,000. According to the literature data, since 2010, mortality from AIDS-related causes in the Republic of Belarus has increased by $22 \%$. A similar situation is typical for Kazakhstan (56\%) and Georgia (297\%). At the same time, in a number of countries in the EECA region, such as Moldova and Ukraine, there was a decrease in mortality from the terminal stage of HIV infection by $23 \%$ and $51 \%$, respectively. Parenteral drug use and male sex increase the risks of death [1-4].

Materials and methods. The method of retrospective epidemic analysis, as well as descriptive-evaluative and statistical research methods were applied for the study.

The material of the epidemiological study was demographic indicators and epidemiological data on the patients' death with an established HIV/AIDS diagnosis in Minsk from 2010 to 2019. Compilation of databases and their statistical processing was carried out using standard statistical software packages Microsoft Excel 10, STATISTICA 10, RStudio. The Clopper-Pearson method was used for calculation of the confidence intervals for extensive indicators [5].

Results. Mortality rates from AIDS in Minsk were characterized by an uneven distribution and ranged from 0.70 (2010) to 2.07 (2019) per 100 thousand population, and the average annual death rate from AIDS was 1.22 cases per 100,000 population. The multiplicity of differences between the minimum and maximum indicators didn't exceed 2.96 times. Epidemic trend of mortality from AIDS in 2010-2019 was significantly expressed for growth with an average growth rate of $8.17 \%(\mathrm{p}<0.05)$. 
Mortality rates from AIDS in Minsk varied from 36.11\% (CI 20.82-53.78, $\mathrm{p}<0.05$ ) in 2010 to $61.19 \%$ (CI 48.50-72.86, $\mathrm{p}<0.05$ ) in 2019, and the average annual death rate from AIDS in Minsk was 46.72\%. Despite significant fluctuations in mortality rates from AIDS (the minimum and maximum indicators differed by 1.69 times) the differences in indicators in a number of years are not reliable and statistically significant.

Among the deceased HIV-infected people in Minsk in 2010, persons aged 30-34 (42.11\% (CI 26.31-59.18, p<0.05)) and 25-29 years old (23.68\% (CI 11,44-40.24, $\mathrm{p}<0.05)$ ) prevailed, however, since 2012, the proportion of deaths among HIV-infected people aged 25-29 y.o. has become significantly lower than the share of deaths in older age groups. The share of deceased HIV-infected people at the age of 30-34, 35-39 and over 40 years old didn't differ significantly in the analyzed time interval. In 2019, the proportion of deaths at the age of 40 y.o. and older was $46.67 \%$ (CI $36.87-56.66 \%$, $\mathrm{p}<0.05)$, which significantly exceeds the similar indicators of deaths at younger ages (fig. 1).

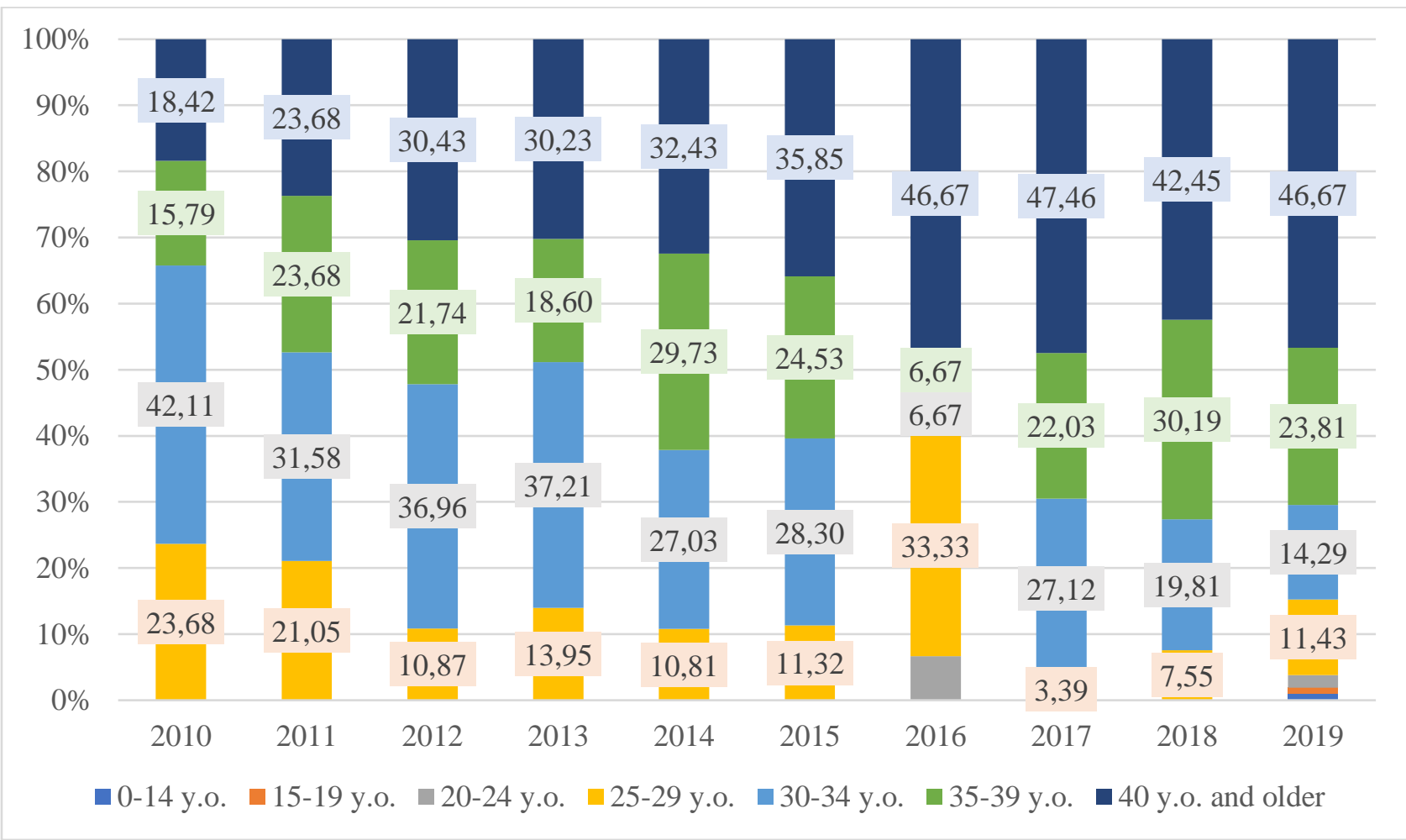

Figure 1. Age structure of HIV-infected people deaths in Minsk in 2010-2019

During 2010-2019, at the age structure of AIDS deaths in Minsk, persons aged 3034 y.o., 35-39 y.o. and over 40 y.o., prevailed. In 2010 their share was 30.77\% (CI 9.09-61.43, p<0.05), 23.08\% (CI 5.04-53.81, p<0.05) and 30.77\% (CI 9,09-61,43, $\mathrm{p}<0.05)$, respectively. The proportion of deaths of people with AIDS aged 30-34 y.o. varied within $5.00 \%$ (CI $0.13-24.87, \mathrm{p}<0.05$ ) in 2017 - 40.91\% (CI 20.71-63.65, $\mathrm{p}<0.05$ ) in 2013 year, however, already in 2019 this indicator increased to $19.51 \%$ (CI 8.82-34.87, $\mathrm{p}<0.05)$. The proportion of deaths from AIDS at the age of 35-39 ranged from $15.00 \%$ (CI 3.21-37.89, p<0.05) in 2014 to $35.29 \%$ (CI 14.21-61.67, p<0.05) in 
2011. By 2019, the share of this group increased and amounted to $26.83 \%$ (CI 14.22$42.94, \mathrm{p}<0.05)$. The proportion of AIDS deaths over the age of 40 y.o. also varied unevenly throughout the analyzed time interval: from $18.18 \%$ (CI 5.19-40.28, $\mathrm{p}<0.05$ ) in 2013 to $55.00 \%$ (CI 31.53-76.94, p<0.05) in 2017. By 2019, the share of this age group decreased in the structure of mortality, but still remained high and amounted to $48.78 \%$ (CI 32.88-64.87, $\mathrm{p}<0.05$ ).

The proportion of younger age groups (0-14 y.o., 15-19 y.o., 20-24 y.o. and 2529 y.o.) didn't make a significant contribution to the formation of AIDS mortality in Minsk. Their total share in 2010-2019 ranged from 4.88\% (CI 0.60-16.53, p<0.05) in 2019 to $15.38 \%$ (CI 1.92-45.45, p<0.05) in 2010. It can be explained by an increase in the share of older age groups (35-39 y.o., over 40 y.o.) in the structure of registered cases of HIV infection in Minsk during 2010-2019, natural aging of the HIV-positive people population who were infected earlier [6].

Conclusions. During the period from 2010 to 2019, AIDS deaths are growing significantly in Minsk, the growth rate was $8.17 \%(\mathrm{p}<0.05)$. The share of people aged 40 y.o. and over in the structure of HIV-infected people deaths is also growing and in 2019 reaches $46.67 \%$ (CI $36.87-56.66 \%, \mathrm{p}<0.05$ ), which is significantly different from the share of deaths at younger age groups. The proportion of AIDS deaths over the age of 30 y.o. prevailed over the younger age groups.

\section{References:}

1. Global AIDS Monitoring 2019: Indicators for Monitoring the United Nations Political Declaration on HIV/AIDS in 2016. Geneva: UNAIDS; 2017. Available from: https://www.unaids.org/sites/default/files/media_asset/global-aidsmonitoring_en.pdf.

2. Focus on communities. The response to the spread of HIV infection in Eastern Europe and Central Asia. Global AIDS 2019 update. Available from: https://www.unaids.org/sites/default/files/media_asset/2019_Regional_GR_EasternEurope-and-central-Asia_ru.pdf.

3. Integration of HIV prevention into medical care for people living with HIV. Recommendations from CDC, Health Resources and Services Administration, National Institutes of Health, and American Society of Infectious Disease HIV Medicine Association Available from: https://www.cdc.gov/mmwr/preview/mmwrhtml/rr5212a1.htm.

4. Alternative Report of the Committee on Economic, Social and Cultural Rights to the initial report of Kazakhstan on compliance with the International Covenant on Economic, Social and Cultural Rights. Available from: https://tbinternet.ohchr.org/Treaties/CESCR/Shared\%20Documents/KAZ/INT_CESC R_NGO_KAZ_44_9356_E.pdf.

5. Lang, T.A. How to describe statistics in medicine. Annotated guide for authors, editors and reviewers / T. A. Lang, M. Sesik; per. from English ed. V.P. Leonova. - M $\therefore$ Practical Medicine, 2011. $-480 \mathrm{p}$.

6. Brief report on the research. Study of the factors contributing to the growth of the number of new and regular clients of low-threshold HIV prevention points for people who inject drugs in the Republic of Belarus. Available from: 
https://www.researchgate.net/profile/Uladzimir_Pikirenia/project/Factorscontributing-to-the-growth-of-the-number-of-new-and-regular-clients-of-lowthreshold-HIV-prevention-points-for-people-who-use-drugs-inBelarus/attachment/59e90b9e4cde2617ef856fd3/AS:551272802721792@150844508 6724/download/kratkiy-otchet-19-10-2017.pdf?context=ProjectUpdatesLog. 


\section{ДЕЯКІ ФІЗИКО-МЕХАНІЧНІ ВЛАСТИВОСТІ САМОАДГЕЗИВНОГО І САМОПРОТРАВЛЮЮЧОГО КОМПОЗИТУ ПОДВІЙНОЇ ФІКСАЦЇ̈ «МАХСЕМ ELITE $^{\mathrm{TM}}$ ЯК ФІКСУВАЛЬНОГО МАТЕРІАЛУ ТА ЙОГО АНАЛОГІВ}

Бєліков Олександр Борисович, Доктор медичних наук, професор, Завідувач кафедри ортопедичної стоматології, Буковинський державний медичний університет

Сорохан Микола Миколайович Асистент кафедри ортопедичної стоматології, Буковинський державний медичний університет

\section{Белікова Наталія Іванівна}

Кандидат медичних наук,

Асистент кафедри ортопедичної стоматології, Буковинський державний медичний університет

При ефективності користування адгезивними мостоподібними протезами треба враховувати наступні критерії: якість адгезивного з'єднання та наявність достатньої площі адгезивних накладок [1]. Кожна накладка повинна мати хвилеподібну форму, подібну до анатомічної поверхні зубів завтовшки до 1 мм, а внутрішня поверхня іiі повторювати оральну поверхню опорного зуба. Це дозволяє створити постійну умову товщини адгезивного шару до 0,1 мм.

Нами була поставлена мета підвищення ефективності мостоподібних протезів адгезивної фіксації за рахунок збільшення площі опори ретенційних елементів і використання фіксуючого матеріалу подвійної фіксації.

Для вирішення поставленої мети на основі фізико-механічних розрахунків як фіксуючий матеріал було запропоновано використання «Maxcem Elite ${ }^{\mathrm{TM}}$ », Kerr, Каліфорнія, США. Цей матеріал являє собою самопротравлючий адгезивний цемент на основі смоли, що випускається у формі паста-паста і призначений для цементування непрямих керамічних, фарфорових, полімерних $\mathrm{i}$ металевих реставрацій [2]. Завдяки тому, що Maxcem Elite ${ }^{\mathrm{TM}}$ сам володіє протравлюючими i адгезивними властивостями, він не вимагає використання протравлювача, праймера або адгезива. Даний продукт містить 69\% (по масі) наповнювача і $є$ рентгеноконтрастним. Матеріал подвійного затвердіння упакований в шприці із одноразовими канюлями для автоматичного змішування $\mathrm{i}$ додатковими вигнутими канюлями для дозування, що дозволяє лікарю ввести необхідну кількість цемента безпосередньо до реставрації або в порожнину зуба.

Оцінювання властивостей самопротравлюючого самоадгезивного цементу "Maxcem Elite" проводилося згідно 3 ISO 4049 "Полімерні пломбувальні 
матеріали" (матеріал належить до класу В тип II), TO ISO TR11405 “Стоматологічні матеріали”, а також ТУУ 24.4-00481318-022-2002. Для його лабораторного дослідження було виготовлено 105 зразків [3, 4, 5].

Оцінку фізико-механічних властивостей самопротравлюючого самоадгезивного цементу "МахСеm" проводили в порівнянні із адгезивнофіксувальними фотополімерними аналогами: Bifix (VOCO) (105 зразків), Relyx U 100», 3M ESPE (105 зразків).

Для створення ретенційних пунктів для опорних площадок використовувався комплект борів, який складався з кулястих алмазних інструментів діаметром 2 i 3 мм, якими будуть створені для адгезивного протеза, тонких подовжених конусоподібних борів із зернистістю 100 мкм для препарування апроксимальних або оральних поверхонь, алмазних борів із зернистістю 25-50 мкм для фінірування країв порожнини і контурування реставрації, карбідних борів для шліфування (з гранями від 12 до 32), а також полірувальних голівок, дисків $\mathrm{i}$ штрипсів для кінцевої обробки конструкції.

Моделювання адгезивної конструкції вимагає дотримання етапів роботи 3 композитами. Планування має на увазі морфометрію зубів та їх підготовку. Вимір параметрів зуба, симетричного видаленому, потрібний для забезпечення точної відповідності конструкції. Висота коронки оцінювалася в проксимальній ділянці від ясен до ріжучого краю (різець) і від ясенного краю до бічного гребня основного горбика (ікло).

Одонтоскопія дозволяє планувати геометричну форму, відтворення ознак належності, а також індивідуальних особливостей зубів: геометрична форма різців - прямокутна; не виражена мезіальна опуклість вестибулярної поверхні, слабо виражена ознака кута коронки. Визначається значних розмірів приясенний валик в ікла і латерального різця.

Міцність з'єднання протеза характеризується критичним напруженням, тобто значенням руйнівних сил, віднесених до одиниці поверхні. Ця величина визначається паспортним параметром композитного матеріалу, відомим як міцність на відрив, який стандартно визначається в лабораторних умовах на імітаторі системи метал-композит-емаль.

В результаті проведених досліджень нами встановлено наступне (табл.1).

Табл. 1

Зведена таблиця основних фізико-механічних показників самоадгезивного матеріалу “ Мaxcem Elite” та його аналогів

\begin{tabular}{|c|c|c|c|c|}
\hline \multirow{2}{*}{$\begin{array}{l}\text { № } \\
\text { 3/ח }\end{array}$} & \multirow{2}{*}{$\begin{array}{c}\text { Показник і його } \\
\text { позначення, } \\
\text { одиниця виміру, } \\
\text { уточнення }\end{array}$} & \multicolumn{3}{|c|}{ Середнє значення та стандартне ухилення для матеріалу } \\
\hline & & $\begin{array}{c}\text { "Maxcem Elite», } \\
\text { Kerr, Калифорния, } \\
\text { США }\end{array}$ & $\begin{array}{c}\text { Bifix QV», VOCO, } \\
\text { Cuxhaven, } \\
\text { Німеччина }\end{array}$ & $\begin{array}{c}\text { Relyx U 100», 3M } \\
\text { ESPE, Міннесота, } \\
\text { США }\end{array}$ \\
\hline 1. & $\begin{array}{c}\text { Зовнішній вигляд } \\
\text { пасти }\end{array}$ & $\begin{array}{c}\text { Високов'язкі, } \\
\text { однорідні }\end{array}$ & $\begin{array}{l}\text { Високов'язкі, } \\
\text { однорідні }\end{array}$ & $\begin{array}{c}\text { Високов'язкі, } \\
\text { однорідні }\end{array}$ \\
\hline 2. & $\begin{array}{c}\text { Глибина твердіння, } \\
\text { мм, не менш }(H)\end{array}$ & $4,62 \pm 0,25^{*}$ & $5,4 \pm 0,27$ & $5,3 \pm 0,26$ \\
\hline
\end{tabular}




\begin{tabular}{|c|c|c|c|c|}
\hline 3. & $\begin{array}{c}\text { Діаметральна } \\
\text { міцність, МПа }(D)\end{array}$ & $47,34 \pm 2,64^{*}$ & $44,1 \pm 2,2$ & $44,0 \pm 2,2$ \\
\hline 4. & $\begin{array}{c}\text { Конічна точка } \\
\text { плинності за } \\
\text { Хепплером, } \\
\text { МПа,не менш( } C)\end{array}$ & $1514,72 \pm 80,3^{*}$ & $1476,5 \pm 73,8$ & $1489,3 \pm 74,5$ \\
\hline 5. & $\begin{array}{c}\text { Твердість за } \\
\text { Хепплером, Мпа, } \\
\text { не менш }(S)\end{array}$ & $784,66 \pm 42,3$ & $732,6 \pm 36,6$ & $756 \pm 37,8$ \\
\hline 6. & $\begin{array}{c}\text { Водопоглинання за } \\
7 \text { діб, мкг } \\
\text { /мм }, \text { не більш( } W)\end{array}$ & $7,34 \pm 0,32$ & $7,6 \pm 0,38$ & $7,2 \pm 0,36$ \\
\hline 7. & $\begin{array}{c}\text { Водорозчинність за } \\
7 \text { діб мкг } \\
\text { ммм }{ }^{3}, \text { не більш }(U)\end{array}$ & $4,23 \pm 0,17^{*}$ & $3,2 \pm 0,16$ & $3,1 \pm 0,16$ \\
\hline 8. & $\begin{array}{c}\text { Адгезивна } \\
\text { міцність, МПа, не } \\
\text { менш }(A)\end{array}$ & $17,31 \pm 0,54^{*}$ & $7,1 \pm 0,36$ & $7,92 \pm 0,4$ \\
\hline 9. & $\begin{array}{c}\text { Міцність на відрив, } \\
\text { МПа, не менш }(R)\end{array}$ & $5,32 \pm 0,27^{*}$ & $4,6 \pm 0,23$ & $5,0 \pm 0,25$ \\
\hline
\end{tabular}

*-достовірна відмінність $(\mathrm{p}<0,05)$ «Maxcem Elite» порівняно із кращим аналогом. Дані таблиці 1 показують, що за середнім за випробуваннями показником глибини твердіння ( $\bar{H}=4,6$ мм) матеріал “ Maxcem Elite" поступається іншим: матеріалу Bifix на 14,9\% та Relyx на 13,3\%. Це суттєво не впливає на якість з'єднання адгезивної конструкції з твердими тканинами зуба, особливо завдяки розробленій нами методиці підготовки опорних зубів.

3 іншого боку, за середнім значенням показника діаметральної міцності ( $\bar{D}=53,2 \mathrm{MПа)} \mathrm{досліджуваний} \mathrm{матеріал} \mathrm{"Maxcem} \mathrm{Elite"} \mathrm{кращий} \mathrm{за} \mathrm{Bifix} \mathrm{на}$ 17,2\%, краще за Relyx на 17,3\%. Порівнюючи ці та інші фізико-механічні властивості матеріалів за середніми показниками, потрібно брати до уваги випадковий характер цих величин [6].

Вивчення рівня водопоглинання свідчить про вірогідну відсутність варіабельності показника досліджуваного матеріалу порівняно 3 порівнюваними аналогами. Значення показника водорозчинності усіх досліджуваних композитів

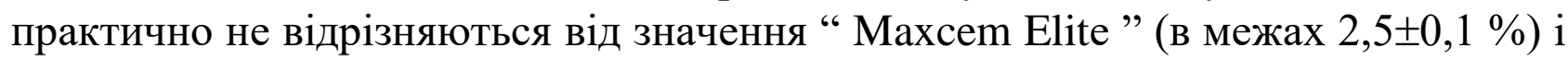
відповідають вимогам ISO 4046.

Серед найважливіших міцневих характеристик, які висуваються до фіксувальних матеріалів, є адгезивна міцність з'єднання з твердими тканинами зуба та міцність на відрив. За показником адгезивної міцності з'єднання 3 твердими тканинами безперечним лідером виявився "Maxcem Elite", який за порівнянням середніх значень вимірювань перевершує Bifix на 37,2\% та Relyx на 30\%, причому, згідно з табл. 1, рівень значущості переваги дуже високий $(\mathrm{P}<0,001)$. Щодо показника міцності на відрив, то він видавався приблизно

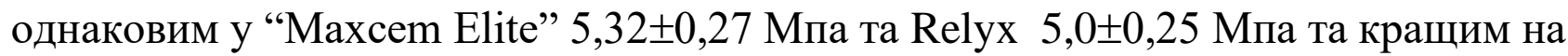
13,6\% по відношенню до Bifix. Але, як видно з табл. 1, перевагу "Maxcem Elite” 
стосовно до Relyx можна стверджувати на задовільному рівні значущості $\mathrm{p}<0,01[6]$.

Високий рівень показників адгезивної міцності з'єднання із твердими тканинами зуба та міцності на відрив забезпечує надійність та тривалість з’єднання системи емаль-композит-метал.

Таким чином, на базі проведення лабораторних досліджень i статистичного аналізу їхніх результатів нами обгрунтовано такі висновки.

Показники матеріалу «Maxcem Elite» загалом аналогічні до показників закордонних аналогів, що вказує на високий ступінь конкурентноздатності досліджуваного матеріалу.

Результати досліджень доводять, що досліджуваний композитний матеріал “Maxcem Elite” за основними параметрами відповідає аналогам, за більшістю показників поєднує в собі кращі їхні характеристики, а за деякими 3 них демонструє кращі показники. А саме: помітно посилена адгезивна міцність 3'єднання 3 твердими тканинами зуба та краща міцність на відрив надають можливість вигідно використовувати матеріал “ Maxcem Elite ” для фіксації адгезивних конструкцій [6].

Отже, на основі результатів комплексної порівняльної характеристики фізико-механічних властивостей досліджуваних матеріалів можна дійти висновку, що цей матеріал можна запропонувати до клінічного застосування, а саме для фіксації мостоподібних протезів, що є методом вибору при лікуванні малих включених дефектів зубних рядів. Показник товщини плівки (мкм) згідно лабораторних досліджень Relyx U100» та «Біфікс» має значення, нижчі стандартних, рекомендованих ISO. «Maxcem Elite» відповідає мінімальній границі показників, що становить 25,7 $\pm 2,9$ мкм.

\section{Список літератури.}

1. Бойко ГИ., Палий ЛИ, Полонейчик НМ и др. Варианты одномоментного замещения дефекта зубного ряда при единично отсутствующем зубе с применением фотокомпозиционных материалов. Медицинский журнал Белорусского национального медицинского университета. 2010;2:146-147.

2. D'Amario M, Campidoglio M, Morresi A, Luciani L, Marchetti E, Baldi M Effect of thermocycling on the bond strength between dual-cured resin cements and zirconium-oxide ceramics. Journal of Oral Science.2010; 3(52): 425-430.

3. ИСО 11405-94. Материалы стоматологические. Руководство по испытанию на адгезию к зубной структуре. Международная организация по стандартизации. 1992: 14.

4. ИСО 4049-88. Стоматология. Полимерные пломбировочные материалы. Международная организация по стандартизации. 1990: 16.

5. Методы механических испытаний. 1964. М.: Изд. Сборник ГОСТов: 145.

6. Сорохан ММ, Бєліков ОБ, Бєлікова НІ, Бєлікова ЛО Порівняльна характеристика фізико-механічних властивостей композитних цементів для непрямих реставрацій. В: Збірник тез наукових робіт учасників міжнар. наукпрактич. конф. Медична наука та практика: виклики і сьогодення; 2020 Серп 2122; Львів; Львів: ГО «Львівська медична спільнота», 2020, с 40-44. 


\title{
ВИБІР ТАКТИКИ ЛІКУВАННЯ ОПІКІВ В ОСІБ ПОХИЛОГО ТА СТАРЕЧОГО ВІКУ
}

\author{
Козинець Георгій Павлович \\ Доктор медичних наук, професор \\ Національний університет охорони здоровя України імені П. Л. Шупика
}

Коваленко Ольга Миколаївна

Доктор медичних наук, професор Національний медичний університет імені О.О. Богомольця

\section{Циганков Володимир Петрович}

Кандидат медичних наук, доцент Національний університет охорони здоровя України імені П. Л. Шупика

На даний час чисельність населення України передпенсійного та пенсійного віку перевищує чисельність чисельність молодого населення і сягає 23\% населення. Такий же демографічний стан визначається і в других Європейських країнах [1.]. Bсе це призвело до зростання питомої ваги постраждалих від опіків осіб даної вікової категорії. За даними літератури пацієнти літнього віку (60 p. і старші) в опікових стаціонарах складають від 16 до 23\% [2.3.] і чисельність їх в найближчі роки буде мати тенденцію до зростання.

Недостатнє висвітлені в літературі ряд питань, що стосуються особливостей перебігу опікової хвороби, вибору методів консервативного лікування, хірургічних втручань та їх впливу на результати лікування опікової хвороби в осіб старше 60 років що вимагає спеціального вивчення цієї проблеми.

Плин опікової травми у літніх протікає на тлі вікових змін що характеризуються інволюцією усіх органів та систем. Витончення та атрофія шкіряного покриву, редукція мікросудиного русла, зниження загальної опорної здатності організму, чисельна супутня патологія обумовлює погіршенням розвитку захисної запальної реакції, стійкості організму до бактеріальних інфекцій, віковим ослабленням імунного захисту та значно утруднює лікування термічного ураження. У ряді випадків специфіка розвитку опікової хвороби обумовлена супутніми захворюваннями у зв'язку з розвитком синдрому взаємного обтяження вже найближчим часом після отримання опікової травми .

Мета дослідження. Визначення тактики лікування опіків у осіб похилого та старечого віку залежно від площі і глибини ураження, супутньої патології.

Матеріали та методи. Аналіз лікування хворих з опіками у віці 60 і більше років,що перебували на стаціонарному лікуванні в опіковому відділенні Київського міського центру термічної травми та пластичної хірургії в $2019-20$ рр.. Всього 96 осіб. 3 них: чоловіків - 51 чол. (53,1\%), жінок - 45 (46,9\%). Основним травмуючим агентом у даної категорії постраждалих стало полум'я 63 чол. (65,5\%), травму гарячими рідинами мали 31 постраждалих - 34,5\%. 
Опікова хвороба у літніх розвивається навіть при обмежених за площею опіках (вже при 5\% поверхні тіла опіку II-III ст.), Характеризується важким перебігом, що пов'язано не тільки зі значним зниженням функції захисноадаптаційних механізмів організму, але також і наявністю, в ряді випадків, важких супутніх захворювань, таких як ішемічна хвороба серця, гіпертонічна хвороба, цукровий діабет та ін. та їх поєднання. Хворі що мали тільки поверхневі опіки склали 44,8\% (43 чол.), Постраждалі де опікове ураження носило глибокий характер склали 55,2\% (53 чол.).

Поверхневі опіках лікувались консервативно, при глибоких лікування було спрямоване на хірургічне очищення рани від некротичних тканин і відновлення цілісності шкіряного покриву. Важливе значення для вибору тактики лікування мав термін надходження постраждалих в стаціонар і пов'язані з цим загальний стан організму і місцеві процеси що відбувалися в опіковій рані. 54 (56,2\%) хворих надійшли в стаціонар в день отримання травми, що дозволило в ранні терміни здійснити необхідні лікувальні заходи для оптимізації перебігу ранового процесу. Інші хворі були госпіталізовані в більш пізній термін, на тлі виникнення ускладнень загального та місцевого характеру, що істотно обмежувало використання тактики раннього хірургічного лікування опікових ран.

Результати та ї обговорення. Постраждалим здійснювалося загальне лікування спрямоване на стабілізацію загального стану, призначалося лікування спрямоване на лікування супутньої патології. Хворі що поступили в гострому періоді опікової хвороби (шок, токсемія) госпіталізувались до відділення анестезіології та інтенсивної терапії.

Місцеве лікування поверхневих опікових ран проводилося з використанням сучасних препаратів для місцевого лікування, таких як мазі на водорозчинній основі, сучасних антисептичних розчинів, використовуваних згідно фази і динаміки перебігу ранового процесу. Термін перебування в стаціонарі у даної групи постраждалих склав 22,4 ліжко дні, що на 2 ліжко дні перевищує показник у більш молодих хворих.

Хворі з опіками II-III ст.. що звернулись до стаціонару в перші 1-2 добу бісля травми отримали комплексне лікування з використанням методів раннього хірургічного лікування (19 осіб), що включало в себе висічення некротичних тканин на 2-3 добу після травми з одночасною аутодермопластикою (АДП) при площині глибокого ураження до7\% поверхні тіла, або 2 разове виконання такого втручання 3 перервою в 2-3 доби у хворих з площею глибокого ураження до 20\% поверхні тіла. Більш поширені глибокі опіки потребували продовження висічення некротичних тканин, однак первинно рани закривались ксенодермотрансплантатом, а після загоєння частки донорських ділянок знов виконувалась АДП на гранулюючи поверхню. Середній термін перебування в стаціонарі в даній групі постраждалих склав 41,3 ліжко днів. Летальність в групі склала

$21,1 \%$.

Хворим з явищами вторинного інфікування ран, та на фоні загострення супутньої патології лікування з включенням активної хірургічної тактики не могла бути запропонована, оскільки суттєво могла погіршити загальний стан 
потерпілого. В даному разі поетапно виконувались дренуючі некротомії, та поетапне видалення некротичного струпу по мірі його демаркації, виконання хімічного некролізу на обмежених площах (1-1,5\% поверхні тіла), з подальшим закриттям гранулюючих ран шляхом АДП. В даній групі постраждалих термін лікування склав 55,71 ліжко день, а летальність склала 46,15\%.

Висновки. Аналіз результатів лікування дозволив виробити тактику хірургічного лікування глибоких опіків у потерпілих похилого та старечого віку:

- раннє хірургічне лікування глибоких, великих опіків у осіб старше 60 років $\epsilon$ найбільш кращим для оптимізації результатів опікової хвороби; - потрібен диференційований підхід для визначення методів хірургічного лікування в залежності від наявної супутньої патології; - при ранньому хірургічному лікуванні обсяг останнього знижується на 30 - 40\% від прийнятого в осіб молодого і середнього віку, для запобігання розладів викликаних операційною травмою;

- при ранньому хірургічному лікуванні кращим є первинне закриття висіченої поверхні шляхом АДП у постраждалих з глибокими опіками до 20\% поверхні тіла;

- ранне хірургічне лікування у хворих з глибокими опіками більше $20 \%$ потребує включення до програм хірургічного лікування використання методів АДП та ксенодермопластики, для можливості стабізації стану потерпілого, та відновлення епітеліального покриву первинних донорських ділянок;

- запропонована тактика оперативного лікування в осіб похилого та старечого віку дозволяє знизить час перебування в стаціонарі на 10-14 діб і зменшити летальність даної вікової групи постраждалих.

\section{Список літератури}

1.Позняк О.В., Шевчук П.С. Демографічні перспективи України до 2060 року // Демографія та соціальна економіка.- 2014.- №1. - С. 72-84.

2. Козулин Д.А., Лазаренко П.П. Общая характеристика контингента пострадавших ожогового центра г. Санкт-Пктербурга. Материалы VIII HK по проблеме «Ожоги» ВМА, СПБ, 1995.

3.Hadjiiski O.: Brulures chez les personnes agees. Ann. of Mediterranean Burns Club, Vol.VII, 1994, p. 63-67 


\title{
ПАРАМЕТРИЧНЕ ОЦНЮВАННЯ ТЯЖКОСТІ СТАНУ І ПРОГНОЗУВАННЯ НАСЛІДКІВ ПОШКОДЖЕНЬ ПРИ ПОЛІТРАВМІ
}

\author{
Трофимченко Тетяна Сергіївна, \\ студентка 5 курсу медичного факультету, \\ Харківський національний медичний університет
}

На сьогоднішній день політравма займає важливе місце в структурі інвалідизації працездатного населення в Україні. Кількість постраждалих від різноманітних травматичних пошкоджень неухильно зростає 3 кожним роком. Актуальність дослідження полягає в тому, що внаслідок збільшення випадків політравми, що характеризуються високою смертністю, виникає необхідність вдосконалення екстреної медичної допомоги.

Незважаючи на те, що з'являються нові системи оцінювання, шкали постійно оновлюються, доповнюються і вдосконалюються, проте ще не створено єдиної універсальної шкали, яка б повністю задовольняла лікарів. Це можна пояснити різноманітністю порушень і пошкоджень, а також тим, що іноді отримана інформація за допомогою шкал і практичний досвід лікаря мають певні розбіжності.

Метою роботи являється визначення необхідності параметричного оцінювання тяжкості політравми на догоспітальному етапі, а також встановлення найбільш оптимальної шкали оцінювання тяжкості стану постраждалих і прогнозування наслідків травми.

Перш за все, задля визначення необхідної лікувальної тактики лікар повинен оцінити тяжкість стану постраждалого i окреслити прогностичну оцінку результатів лікування. Дуже часто рішення стосовно лікування базується на особистому досвіді лікаря і не $\epsilon$ науково обгрунтованим. 3 цією метою $\epsilon$ доцільним використання спеціальних шкал оцінки тяжкості стану постраждалих і прогнозування наслідків травми.

При створенні діагностичної шкали можна виділити чотири основних завдання:

- 1 - класифікація пошкоджень;

- $\quad 2$ - об'єктивна оцінка тяжкості стану;

- 3 - сортування постраждалих;

- $\quad 4$ - прогнозування наслідків травми.

Ці задачі тісно пов’язані між собою, тому що від тяжкості травми залежать терміни та обсяг невідкладної допомоги і прогноз щодо її наслідків.

Для того, щоб обрати відповідні оптимальні методи оцінки тяжкості стану постраждалих i прогнозування наслідків травми, необхідно провести порівняльний аналіз шкал $[3 ; 5]$.

Нині відомо більше 50 шкал для оцінювання тяжкості політравми. Проте всі вони поділяються за трьома основними напрямами (Таблиця 1). 
Таблиця 1

Основні напрями поділу шкал для оцінювання тяжкості стану постраждалих

\begin{tabular}{|c|c|c|}
\hline Аналіз & Напрям оцінки & Приклади шкал \\
\hline Кількісний & Підрахунок та оцінка тяжкості пошкоджень & AIS, CRIS, ISS, PTS, \\
& окремих анатомічних та анатомо- & ICISS, NISS, APS \\
& функціональних областей організму & \\
\hline Якісний & Оцінка тяжкості за загальним станом & RTS, VSS, APACHE, \\
& постраждалого, вітальними функціями і & SAPS, MODS \\
& фізіологічними параметрами & \\
\hline Комбінований & Поєднання кількісного і якісного варіантів & $\begin{array}{c}\text { TRISS, BПХ-Cорт MFs - } \\
\text { Sort, BПX - П(MT) }\end{array}$ \\
\hline
\end{tabular}

Джерело: складено автором за матеріалами [5]

Оскільки на сьогодні існує широке різноманіття шкал для оцінки тяжкості стану постраждалих (класифікація шкал наведена на рисунку 1), то виникає необхідність порівняння їхньої прогностичної ефективності для того, щоб обрати найзручнішу і найпростішу у використанні. Через дефіцит часу на догоспітальному етапі необхідна шкала, яка не потребує складних розрахунків та може бути використана у випадку тяжких поєднаних пошкоджень.

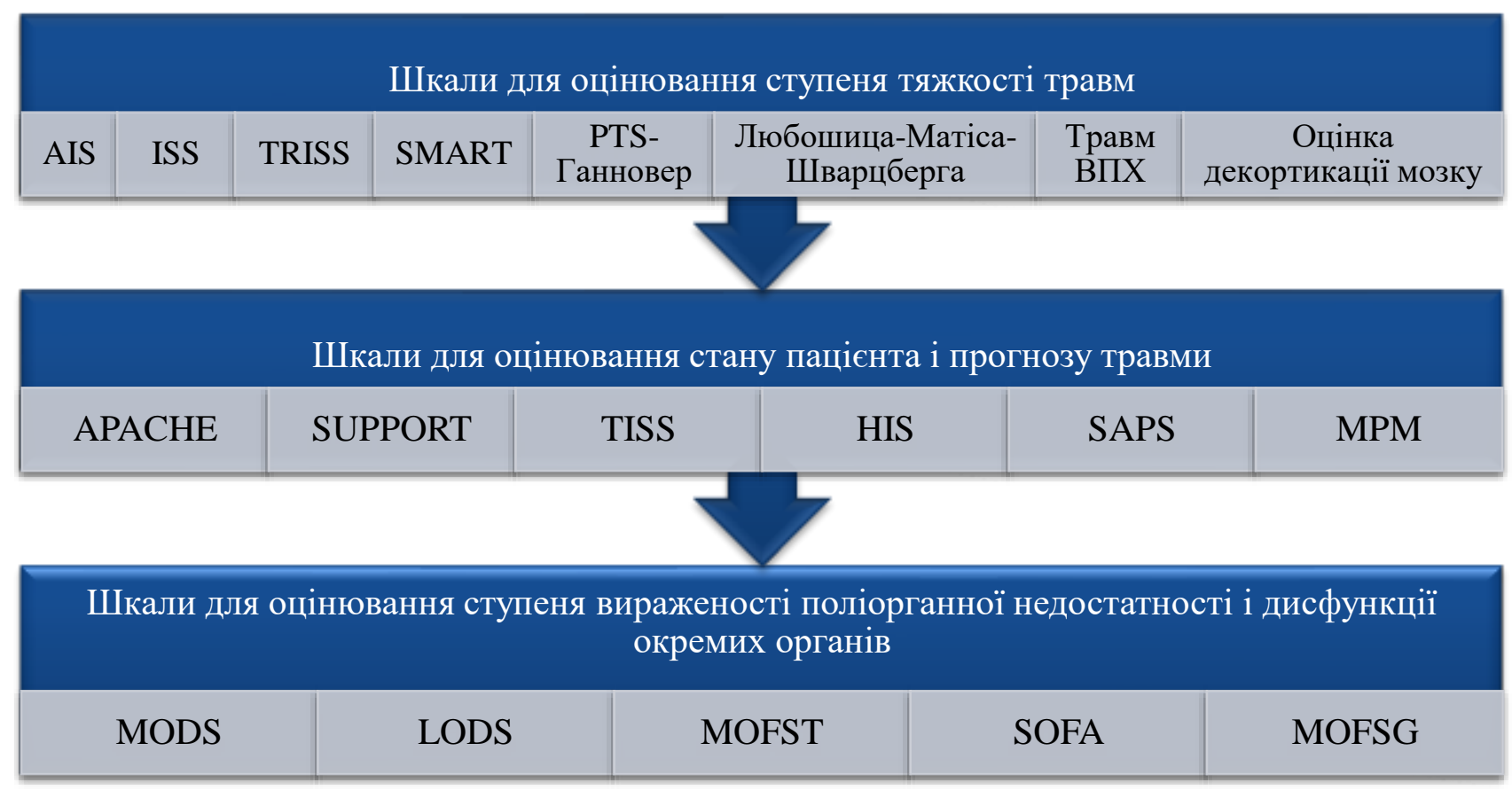

Рис. 1. Класифікація шкал оцінки тяжкості політравми Джерело: складено автором за матеріалами [6]

Система ISS базується на сумації балів пошкоджень в трьох 3 шести умовно виділених областей: голова, хребет, грудна клітина, живіт, таз та кінцівки. Потім обирають три найбільших по значенню показника і вводять їх в квадрат та додають. Недоліком цієї шкали є те, що в межах однієї ділянки тіла беруть до уваги тільки найтяжче пошкодження, при цьому інші важливі для прогнозу травми залишаються неврахованими. Це призводить до помилок в оцінюванні. Незважаючи на недоліки, шкала ISS дає змогу адекватно оцінити тяжкість 
отриманої травми, провести медичне сортування i визначити оптимальну тактику лікування.

В противагу, шкала NISS визначає тяжкість травми додаванням квадратів балів трьох значних пошкоджень незалежно від їх локалізації.

ICISS - модифікована шкала ISS, за допомогою якої можна прогнозувати ймовірність смерті емпіричним методом: будь-який варіант травми позначається кодом відповідно до МКХ. Для кожного коду розрахована смертність на основі аналізу бази даних результатів лікування. Проте іiі недоліком є необхідність періодичного перегляду внаслідок прямої залежності від МКХ та неможливість застосування на догоспітальному етапі.

Як приклад багатофакторної оцінки тяжкості стану є травматична шкала (Trauma Score), що включає в себе оцінку основних параметрів життєдіяльності i функціональних порушень діяльності ЦНС. Спрощеним варіантом TS є RTS (Revised Trauma Score), яка більшою мірою придатна до повсякденного практичного застосування.

Величина RTS бере до уваги оцінку свідомості, частоту дихання i систолічний артеріальний тиск. Вона є досить специфічною для травми, проте допомагає розподіляти постраждалих до групи з певною ймовірністю виживання $[3 ; 5 ; 6]$.

Система AIS дозволяє розподіляти пошкодження кожного внутрішнього органа на 6 груп за тяжкістю отриманого ушкодження:

- мінімальні - 1 бал;

- помірні - 2 бали;

- серйозні - 3 бали;

- тяжкі - 4 бали;

- критичні - 5 балів;

- несумісні з життям - 6 балів.

Проводиться оцінка кожного пошкодження області за балами шкали, найвищий бал з якої і є ступенем тяжкості ушкодження. Основні переваги шкали AIS - ii простота i достатня кореляція 3 наслідками травми, а недолік можливість прояву суб' єктивізму в формуванні критеріїв оцінювання. Шкала не передбачає оцінку тяжкості поєднаних і множинних травм.

Шкала АРАСНЕ бере до уваги оцінку гострих фізіологічних змін, хронічні захворювання та вік постраждалого. Її перевагою $\epsilon$ те, що вона може бути використана для прогнозування результатів лікування. На основі оцінки тяжкості стану можна розрахувати ризик смерті постраждалого в лікарні. Незважаючи на широке застосування шкали АРАСНЕ в прикладній медицині, вона непридатна на догоспітальному етапі надання медичної допомоги.

Шкала SAPS є дещо полегшеним варіантом оцінювання тяжких хворих. Для визначення тяжкості використовують 14 біологічних і клінічних показників.

В Україні використання шкал APACHE i SAPS обмежене через необхідність для їх розрахунку показників газового складу крові, бікарбонатів сироватки, концентрації натрію та калію, що на практиці не завжди можливо у зв’язку 3 організаційними труднощами [2-4]. 
Для об'єктивної оцінки тяжкості стану постраждалих розроблено шкалу ВПХ-П (СП) (стан при надходженні). До уваги беруть колір шкірних покривів, стан дихальної системи, ЦНС, кровообігу, ШКТ та орієнтовний об'єм крововтрати. Кожну з ознак оцінюють у балах (від 1 до 9). Індекс тяжкості стану постраждалого визначають шляхом додавання балів всіх ознак. Таким чином, значення індексів тяжкості стану розраховані з урахуванням ймовірності летального наслідку і розвитку ускладнень (наприклад, сума у 30 балів відповідає тяжкому стану постраждалого, а сума у 45 балів - вкрай тяжкому, несумісному з життям) $[1 ; 2]$.

На основі проведеного дослідження можна констатувати, що оцінка тяжкості стану постраждалого $\epsilon$ першочерговим завданням при наданні медичної допомоги. Різноманітність варіантів пошкоджень і функціональних порушень в організмі при політравмі, необхідність швидкого прийняття рішень стосовно діагностики та тактики лікування вимагає градації тяжкості стану постраждалого. Отже, доречність використання шкал для оцінювання тяжкості стану та прогнозування наслідків не викликає жодних сумнівів.

Проведений аналіз літератури показав, що для стандартизації діагностичних заходів і впровадження в повсякденну практику шкал оцінювання тяжкості стану необхідно враховувати етап надання медичної допомоги, рівень підготовки медичних працівників i матеріально-технічне забезпечення лікувального закладу.

Таким чином, в ургентній допомозі ключовими факторами є час і вибір оптимальної лікувальної тактики. Тому стандартизовані системи оцінки тяжкості пошкоджень та стану постраждалого на догоспітальному етапі повинні бути прості, достовірні, інформативно значущі, швидкі в розрахунку. Усім вищезазначеним критеріям в певній мірі відповідає шкала кафедри військовопольової хірургії пошкоджень (стан при надходженні) - ВПХ-П (СП). Вона проста у використанні, орієнтована на клінічні ознаки, що не потребують для свого визначення додаткового обладнання, і має високий ступінь достовірності. Незважаючи на те, що шкала ВПХ-П (СП) створена для оцінки стану при надходженні до стаціонару, вона може бути використана і на догоспітальному етапі.

\section{Список використаних джерел:}

1. Военно-полевая хирургия: учебник. 2-е изд., изм. и доп. / под ред. Е. К. Гуманенко. М. : ГЭОТАР-Медиа. 2008. 768 с.

2. Гуманенко Е. К. Сочетанные травмы с позиции объективной оценки тяжести травм : автореф. дисс. д-ра мед. наук.. Л. : СПб. 1992. 50 с.

3. Гур'єв С. О., Шкатула Ю. В. Стандартизована оцінка шокогенності поліорганних та полісистемних пошкоджень у дітей на догоспітальному етапі // Вісник СумДУ. Серія «Медицина». 2012. №1. С. 123-130.

4. Мазуренко О. В, Рощин Г. Г., Барамія Н. М., Новиков Ф. М. Використання шкал для оцінки ступеня тяжкості постраждалих 3 травмою // Проблеми 
військової охорони здоров’я : збірник наукових праць УВМА. Київ. 2002. №2. 64 c.

5. Семенов А. В., Сороковиков В. А. Шкалы оценки тяжести и прогнозирования исхода травм // Политравма. 2016. №3. С. 80-90.

6. Агаджанян В. В., Кравцов С. А. Состояние экспертной оценки проблемы политравмы и её финансирования [Электронный ресурс] / Научно-клинический центр охраны здоровья шахтёров. 2014. URL: http://congressph.ru/common/htdocs/upload/fm/travma14/19/19-49.pdf. 


\title{
MODERN TECHNOLOGIES AND OPPORTUNITIES FOR INCREASING THE PROFESSIONAL LEVEL OF PHARMACY SPECIALISTS DURING THE COVID-19 PANDEMIC
}

\author{
Mishchenko Oksana \\ Dr. of Pharmacy, Professor \\ Kharkiv National University of Pharmacy \\ Bezdetko Natalia \\ MD, Professor \\ Kharkiv National University of Pharmacy
}

The most pressing issue in the life of the population of all countries is currently the pandemic of the new coronavirus infection COVID-19. More than people of all other professions, the problem of COVID-19 is faced by professionals who work in the health sector. These are both doctors and nurses, as well as pharmacists in a pharmacy. Doctors of all specialties must have information on the epidemiology, diagnosis, and prevention of this disease. Most of the work in a pandemic is done by family doctors and general practitioners. It is to these doctors that people who fall ill with COVID-19 turn to with the first symptoms of the disease. The family doctor must solve all questions about the diagnosis and treatment of patients with COVID-19 at the outpatient stage. He should be aware of all the new recommendations for outpatient treatment. Also, the doctor should know as much as possible about the drugs that are prescribed on an outpatient basis for the treatment of patients with COVID-19. The physician should regularly receive the latest data on the effectiveness and safety of various drugs for the treatment of COVID-19. These are drugs of such pharmacological groups: antipyretic, antiinflammatory, antiplatelet agents, glucocorticosteroids, antibiotics, restorative drugs, hepatoprotectors, bronchodilators and others.

Knowledge about possible methods of increasing the body's resistance to infection is very important. In the scientific literature, information constantly appears about overthe-counter drugs that increase the body's nonspecific protective capabilities, help fight the symptoms of anxiety and fear of illness. Information on the pharmacological properties of OTC drugs is given to the patient by a pharmacist in a pharmacy. To do this, the pharmacist must know the latest data on OTC drugs and the possibilities of using it in COVID-19.

Among people who have received an infection with the SARS-COV-2 virus, there are a lot of patients with concomitant cardiovascular diseases, diabetes mellitus, and diseases of the broncho-pulmonary system. It is this category of patients with comorbid deseases that is at increased risk of severe form COVID-19 infection. Patients with chronic diseases receive constant basic therapy. During the COVID-19 pandemic, 
pressing questions are: how to change basic therapy in chronic patients who have not contracted COVID-19; how to change the basic therapy in chronic patients who are ill with COVID-19; what may be the interaction of drugs of basic and antiviral therapy. For several years, the Department of Clinical Pharmacology of Institute of qualification improvement for pharmacists, National University of Pharmacy has been conducting professional development cycles for doctors on topical issues of clinical pharmacology. For pharmacists, professional development cycles are carried out on topical issues of clinical pharmacology and pharmaceutical care of OTC drugs. During the pandemic, the Department of Clinical Pharmacology developed a new cycle for doctors "Features of the use of common drugs in the context of the COVID-19 pandemic." In a short time, the cycle program was created. In accordance with the program, 12 new lectures were developed on the basis of the latest scientific data, clinical recommendations of the WHO and the Ministry of Health of Ukraine. Situational tasks have been created to solve practical issues of the use of drugs in comorbid patients.

During the quarantine period, it is possible to use only distance learning. Distance education is an education system that involves active communication between a student and a teacher using modern information technologies. Distance learning in postgraduate education has many benefits: the possibility of learning at an individual pace - the speed of learning the material is set by the student, depending on his desire; individual training - the possibility of in-depth training of specific topics, effective mobile feedback between the teacher and each student; high technological effectiveness of training - the use of the latest information technologies; the possibility of studying does not depend on the geographical location of the institution of higher education. At the same time, distance learning has its negative sides: lack of live communication between student and teacher; lack of constant monitoring requires higher motivation to learn. Effective distance learning is possible only on condition of modern technical equipment of the university; teachers should be proficient in computer technology and be able to work in distance programs.

At the Institute of qualification improvement for pharmacists NUPh, the introduction of modern distance forms of education began long before the pandemic. There is the necessary modern technical equipment, a developed Internet network, teachers have completed a special training course in distance education. Thanks to this, there were no technical difficulties in carrying out the new cycle. For the first time, the Department of Clinical Pharmacology held a new cycle of advanced training for doctors in January 2021, for pharmacists - in February 2021. The topics of the cycle, the content of lectures and seminars, the form of remote conduct received support and a positive assessment of the doctors pharmacists from Kharkiv and Sumy regions appreciated the new cycle of professional development. The positive experience gained has become the basis for conducting this cycle for doctors and pharmacists from other regions of Ukraine. 


\title{
FORMATION OF CREATIVE POTENTIAL OF THE FUTURE TEACHER DURING THE INTERNSHIP IN CHILDREN'S SUMMER HEALTH CAMPS
}

\author{
Nozdrova Oksana, \\ Candidate of Pedagogical Sciences \\ Senior Lecturer at the Department of Pedagogy, \\ South Ukrainian National Pedagogical \\ University named after K. D. Ushynsky \\ Bartienieva Iryna, \\ Candidate of Pedagogical Sciences \\ Senior Lecturer at the Department of Pedagogy, \\ South Ukrainian National Pedagogical \\ University named after K. D. Ushynsky
}

Pedagogical practice is one of the important ways to implement joint design of the process of professional training of future teachers to organize personality-oriented learning, where the main participants are the triad: teacher — student — methodologist [4].

Student creativity is one of the most important conditions for becoming a future specialist. This position is investigated by V. Slastyonin, E. Shiyanov, I.A. Bartashnikov, D.B. Bogoyavlenskaya, and S.O. Sysoeva.

V.I. Andreev, G.M. Kodzhaspirova, Yu. M. Kulyutkin, I. Ya. Lerner, P.I. Pidkasisty, L.S. Podymova, V.A. Slastyonin and others. The vast majority of authors are united in understanding the psychological and pedagogical essence of this phenomenon: a creative personality should be understood - an individual who has a high level of knowledge, has a desire for a new original. For the creative personality of a specialist, creative activity is a vital need, creative style of behavior is the most typical.

Summer pedagogical educational practice intensively influences the formation of the future teacher's personality, allows to obtain essential information about his professional readiness. We are convinced that the quality of students 'internships as detachment counselors is inextricably linked with the quality of students' preparation for educational practice in higher education institutions.

The purpose is to study the state of formation of creative potential of future beginning teachers through pedagogical practice in children's summer health camps.

During the summer pedagogical practice, the task of teachers, in our opinion, is not only to form professional knowledge, skills and abilities of students, but also to develop their personal qualities needed in the future profession, ie to form a professionally oriented personality. We believe that this should contribute to the formation of the student's personality as a competent specialist. Therefore, the problems of formation 
of professional competence of future teachers acquire special significance during training in a higher pedagogical educational institution.

Pedagogical educational practice of students in children's summer health camps included three stages: preparatory, basic and final.

Preparatory stage of educational practice:

- study of the theoretical course «Methods of educational work in children's summer health camps»;

- participation in the distribution of summer internships;

- participation in instructive-methodical seminars;

- taking a test in the discipline «Methods of educational work in children's summer health camps»;

- participation in the competition of leadership skills «School of counselors», in the introductory conference on summer educational practice;

The main stage of educational practice: performing tasks of practice in summer children's health camps, on school grounds, at social services for children.

The final stage of educational practice: registration of reporting documentation; passing a test on summer educational practice; participation in the final conference.

We will describe the main purpose of the organizational period in the children's health and recreation camp - to lay the foundations for the formation of a temporary children's team.

Organizational tasks:

1) identify the level of organizational skills and abilities of children;

2) determine the creative (intellectual, sports, etc.) potential of each child;

3) identify leaders in the children's team;

4) divide the detachment into microgroups, determine the prospects of each of them;

5) determine the prospects of the entire children's team (planning);

6) to organize the primary team.

Methodical tasks:

1) compliance with all requirements of the camp regime and sanitary and hygienic norms;

2) teach to follow the traditions and rules of the camp;

3 ) teach to work in a microgroup, in the primary team;

4) teach each child to analyze their condition and mood (through play forms).

Educational tasks:

Start forming relationships between the following groups of actors:

1) child - child (girls - boys, boys - boys, girls - girls, leaders: formal - informal;

2) child - team;

3) child - adult.

To address these challenges can be used collective creative affairs (CCA).

The system of collective and creative affairs of the organizational period

The first day of the organizational period is the first day of the camp shift - the day of acquaintance. The main goal is to acquaint children with each other, with counselors and educators, with the camp. 
On this day, CCA are held for acquaintance. They do not require long and complex training. The most traditional have become such as «The Light of Dating» (begins with the game «Snowdrops» - remembering names), a trip to the camp (guides-guides are prepared in advance to tell about all the «sights» of the camp). You can offer other CCA: «Lightning Concert», "Chamomile Concert», «We went we went». In the process of their preparation and conduct, children get acquainted, there is an opportunity to discover their creative abilities.

The second day of the organizational period can be conditionally called «the day of self-determination».

Main goals:

1) individually self-determine the child, ie show their talents, abilities, character traits, requirements, etc.;

2) determine their place in the team;

3) determine the place of the micro-team in the macro-team. Of course, selfdetermination of both the child and the children's team takes place not only on the second day of stay in the camp. This process usually lasts the first few days of the camp shift, but the main load falls on the second day.

On the second day of the organizational period, CCA are held to identify leadership in the children's team: «Filming», «Inhabited Island»; any relay game with creative tasks. You can go in search of treasure, or organize a «Journey to the Mirror». As a result of such CCA, leaders are found involuntarily, counselors and educators only observe, if necessary, correcting the behavior of children.

On the same day, organizational meetings are held in detachments, which are designed to address the following issues:

- to determine the rules of life of the children's team;

- identify leaders;

- divide the children's team into microgroups;

- elect self-government bodies;

- to determine the prospects of the team - planning

The third day of the organizational period is the opening of the camp shift.

The main goal - to create a festive mood, an atmosphere of unity of children and adults.

It is necessary that each group and each child become participants of the holiday, not just spectators on this very important day for the whole camp shift. The first general camp line-up is held, the opening of the camp shift is announced. The further program can be the most various: relay races, competitions, big Olympic Games, a disco.

Consider the main period of the camp shift. Purposes:

1) the formation of a temporary children's team;

2) stabilization of the life of the children's team (through the work of selfgovernment bodies, CCA).

Every day, counselors conduct detachments of CCA, which do not require long and complex training, such as «Pantomime», «Chamomile». You can offer children, hold sports relay races, learn new games, just read and discuss the book. This day is very important for counselors and educators, as it is necessary to analyze the past thematic 
period and take into account the conclusions and recommendations (both positive and negative).

The final period. Purpose: to summarize the entire camp shift.

Task:

1) summarizing the "business" results of the change (accept a certain reward system);

2) emotionally complete the camp shift. Traditionally, «Tell me about me» lights are held in the detachments. It is important to be able to choose the right tone in the conversation, to create a friendly atmosphere. Thus it is possible to use any mascot of group, to gather at a «cherished» tree, all together to execute a favorite song, for conversation it is necessary to find a common subject. It is necessary that children speak more at the meeting, and adults only direct the conversation in the right direction. A festive line-up of the closing of the camp shift and a general gathering are held, at which awards are presented to the detachments and children who showed themselves most clearly during the camp shift.

Conclusions. The main task facing high school today is the formation of a harmoniously developed, socially active creative personality of the student, who not only has knowledge but also the ability to self-education and self-development, ability to solve non-standard problems, responds to changes in society and at the same time focuses on eternal universal values. Therefore, modern education opens new ways to improve the professional training of future teachers through pedagogical practice.

Thus, the training of a modern novice teacher is impossible without purposeful and systematic work to update his professional and creative potential.

\section{References}

1. Ovcharuk O. Competences as a key to updating the content of education // Strategy of education reform in Ukraine. Kyiv: KIS, 2003. P. 13-41.

2. Khutorskaya A. Key competencies as a component of personality-oriented paradigm of education // Public education.2003. № 2. P. 58-64.

3. Osipova T. Methods of educational work in the camp: a workshop on a special course. Kharkiv: Burun Kniga, 2008. 120 p.

4. Shmakov S. Vacation (Applied «encyclopedia»: teacher, counselor). Moscow.: Novaya shkola, 1994. $130 \mathrm{p}$. 


\title{
CREATIVITY AT SCHOOL
}

\author{
Soluianova Ganna \\ Assistant Principal of teaching and education work \\ Communal Institution \\ “Kharkiv secondary school I-III levels № 49 \\ Kharkiv city council Kharkiv region \\ named after Kharkivskykh dyvizii"
}

We live in the developing society and our aim today is to educate a person of a new formation. The New Pedagogic Science allocates the 4 Cs of $21^{\text {st }}$ Century Skills. They are:

- Critical Thinker (solving problems);

- Communicator (understanding and communicating ideas);

- Collaborator (working with others);

- Creator (producing high quality work).

On the other hand we as teachers use Bloom's Taxonomy in our educational process. Bloom's Taxonomy is a classification of the different objectives and skills that educators set for their students (learning objectives). Like other taxonomies, Bloom's is hierarchical, meaning that learning at the higher levels is dependent on having attained prerequisite knowledge and skills at lower levels. And "Creating" is on the top of this pyramid. That's why I think that creativity is a unique and a necessary skill for successful person nowadays.

A simple definition of creativity is not possible, as creativity comes in so many different forms. Creativity can involve using one's imagination, changing existing ideas, being unique, original and innovative, having a vision, or simply having the freedom to come up with new and unusual ways to carry out tasks. Classrooms around the world are filled with wonderful resources for creativity, innovation, ideas and possibilities to think 'outside the box'.

Language teachers have three advantages that can help stimulate creativity in students.

First, language is creative by its very nature. We can express or communicate one idea in many different ways. Furthermore, every expressed or communicated idea can provoke many different reactions. Every single sentence, phrase or word we say or write is created in a unique moment of communication and can be recreated, reformulated, paraphrased or changed according to the goals of the speaker or writer. For example, during the lesson which was devoted to the New Year I propose students such activities as "Whispering Messages" and "QR-jumbled words". These activities were very enjoying for students. They liked them very much and now we use these activities very often. "QR-jumbled words" were made in the shape of decorating balls and they were on the New Year Tree as a decoration. So students had to come and choose his own task.

Second, language classes are not limited by any specialized subject or knowledge. Language teachers can, therefore, build their lessons on topics related to sport, 
management, law or philosophy and still focus on language. This is why a communityof-practice setting, where students and teachers share their individual types of expertise and knowledge, can be more easily established. During our lessons we can solve different problems in English, find out origins of mathematical definitions, make floral decoration for our houses and classrooms, discuss environmental problems, communicate with specialists via Skype, play Mystery Skype with students from different countries.

Third, language classes can easily engage students in creative situations. By creative situations we mean close-to-reality situations in which students do not use well-known and practised steps that can be applied almost automatically in order to achieve one correct solution to a problem. In creative situations, students have to produce one or more answers to a series of inter-connected problems. They do not know what steps can be used to solve a problem, they may not be sure if the problem has one solution, a wide range of possible solutions or if it has any solution at all. Students simply do not encounter clear-cut situations that can result only in 'succeedfail' or 'correct-incorrect' solutions, rather they face unclear situations with unclear and tentative solutions. Sometimes, even the setting of a situation or instructions can require a certain level of interpretation. Since language usage represents a form of communication that can be used in near-reality situations can be created more easily than in classes of chemistry or history, for example. The experience of solving such situations we gain from the collaborating on the projects on e-twinning platform. Children have the opportunity to work on the problem together with the students from other countries. They get collaborative skills, organizational skills, teamwork, numeracy and IT skills.

The digital age has brought state-of-the-art devices and gadgets which are supposed to improve the learning process, but it also triggered an ongoing debate as to whether this technology is killing or boosting the creativity of our students.

I work in a State Secondary School so I must admit that we haven't enough equipment but we compensate with a lot of energy, creative ideas and enthusiasm. We also have drama experience. Every year we take part in the "English with pleasure contest". We make different performances. Students like to take part in them because they broaden their abilities, possibilities. Also it helps to communicate in a foreign language. Because our performances always close to our life, they have the situations from our modern life. All these shows are filmed and all people have an opportunity to see them on You Tube channel at any time.

To sum up, a creative approach to language teaching, which is based on the idea that any student can be creative when they are engaged in creative situations, shows students the complexity of a language by exposing them to close-to-real-life situations in a safe, flexible and dynamic environment by means of a class of learners constituted as a community of practice.

Creativity is a complex field studied and discussed from many different perspectives. This is one of the reasons why there is no generally accepted definition and we always have to be aware of the point of view we take in defining creativity. A creative approach to language teaching is an approach that presents creativity as one of our many innate skills, a talent that every person and every language learner has. 
"Everybody is a genius. But if you judge a fish by its ability to climb a tree, it will live its whole life believing that it is stupid" as Albert Einstein says. This approach focuses on the idea that we all can enjoy the potential to be creative under certain conditions; that we all abound with many different forms and levels of creativity and that is the teachers' task to stimulate the creative potential in students.

\section{REFERENCES}

1. Maley A., Peachey NB. (2015) Cteativity in the English language classroom. British Council.

2. Fraser, D (2006) The creative potential of metaphorical writing in the literacy classroom. English Teaching^ Practice and Critique 5/2: 93-108.

3. В.Колошин, Д.Гуменюк. Розвиток творчості учнів Харків: Основа, 2008. c. 110 . 


\title{
ВИКОРИСТАННЯ СЕРВІСІВ ПРИ ДИСТАНЦЙНОМУ НАВЧАННІ ГЕОГРАФІї
}

\author{
Асманська Лариса Костянтинівна \\ директор, вчитель географії, \\ Одеська загальноосвітня \\ школи №92 I-III ступенів \\ Одеської міської ради \\ Одеської області
}

Одним із найважливіших завдань розвитку освіти в Україні у XXI ст. $є$ забезпечення безперервності процесу навчання i виховання, формування всебічно розвиненої особистості в умовах постійних викликів. Метою нашої роботи є вивчення та аналіз можливостей різноманітних сервісів задля їх ефективного використання на уроках географії.

Для організації дистанційного навчання з будь-якого предмету бажано мати єдиний підхід усього навчального закладу, що дає можливість і вчителям, i учням, і батькам навчитися та налаштуватися на роботу. Зручними, на нашу думку, $є$ такі перевірені в роботі дистанційні платформи, як GOOGLE CLASSROOM, MOODLE, «Мій клас», Classdojo, HOBI ЗНAHНЯ, HUMAN ШКОЛА, Edmodo. Вони дають можливість вчителю готувати та викладати навчальні матеріали, презентації, відео, практичні роботи, здійснювати перевірку знань та оцінювання за допомогою тестів (GOOGLE FORMS, Quizlet , Proprofs, Testorium, Kahoot!, ClassMarker, PLICKERS, EASY TEST MAKER). Середовища і додатки для співпраці та оцінювання - «Сдина школа», eschools.info, використання електронних щоденників. Чудову можливість проводити відеозустічі для опитування учнів, пояснення завдань або нового матеріалу, консультацій, відеоуроків, конференцій з обміну досвідом, вебінарів дають додатки GOOGLE MEET, ZOOM. В цих додатках досить зручно не тільки спілкуватись, а й демонструвати презентації, навчальні відео, карти, схеми, таблиці, досліди та інше.

Умови дистанційного навчання змушують нас шукати нові підходи та методи при підготовці до уроків з географії, а також до ЗНО. Щоб допомогти учням краще запам'ятати матеріал, можна використовувати різноманіті інтерактивні сервіси з географії. На курсах 3 HО Educator та при проведенні онлайн-уроків часто використовуються згадувані сервіси, що допомагає зацікавити учнів. Сервіси Google - від Google Maps та Street View до Arts\&Culture - варто застосовувати для закріплення матеріалу з багатьох тем. На особливу увагу заслуговують онлайн-тести для перевірки знань 3 географії та підготовки до ЗНО, які коректно відображаються та зручні у використанні на мобільному гаджеті.

Інша проблема, яка постає перед педагогом - це оцінка знань та умінь за умов дистанційного навчання. Існує велика кількість онлайн-платформ, які 
допоможуть учителю вирішити цю проблему. Зокрема педагог може використати вже готові, розроблені спеціалістами, тести, які на веб-ресурсах розміщені за темами у відповідності до навчальної програми з географії для різних класів. Пропоновані завдання різнопланові та розраховані на всі рівні підготовки: вибрати правильні відповіді, знайти відповідність або певну послідовність. Первага ресурсу полягає в тому, що по завершенню тесту фіксується результат в кількісному складі та час, витрачений на роботу. Так, тестування з підготовки до ЗНО можна використовувати для перевірки знань не тільки старшокласників, а й інших учнів, що вивчають відповідну тему. Це допоможе підготуватися до узагальнення матеріалу. У власній діяльності за цим напрямком роботи використовуємо ряд сайтів: zno.osvita.ua, Be Smart, iznotest та освітній портал «Вне школы».

Веб-ресурси для поглиблення знань 3 географії займають окрему ланку в нашій системі роботи. Для зацікавлення учнів навчальним предметом, надання додаткових джерел інформації пропонуємо використовувати наступні сайти:

- ATLAS for the END of the WORLD надає корисну інформацію про статут землекористування та урбанізації в найбільш заселених регіонах Землі та дані за біорегіонами;

- Earth - веб-ресурс, який надає можливість учням у форматі 3D переглядати рухи океанічної води - течії; перевертати планету Земля з різних ракурсів; прослідкувати формування та положення баричних центрів на материки;

- Windy надає можливість детально ознайомитись зі змінами погоди на певній території: температура повітря, напрям та сила вітру, хмари, опади. Учні можуть самостійно спостерігати процеси, які відбуваються на Землі.

Завжди цікавими та захоплюючими для дітей $є$ онлайн-ігри, вправи та тренажери для вивчення географії. Важливо під час кожного уроку урізноманітнювати діяльність учнів ігровими інтерактивними завданнями, які підтримуються мобільними пристроями.

Наприклад, Seterra - захоплююча освітня географічна гра, яка дозволяє закріпити знання про країни, столиці, прапори і міста Африки, Європи, Північної та Південної Америки, Азії та Австралії за допомогою вправ 3 контурними картами. Веб-ресурс підтримує 33 мови і користується популярністю серед людей по всьому світу.

Універсальний інструмент Learningapps.org дозволяє використання мобільного гаджету на всіх етапах уроку, незалежно від навчального предмету. Сайт вміщує велику колекцію напрацьованих завдань, яку можна застосовувати в навчальній діяльності або скористатися конструктором і створити власні вправи.

У глобальній мережі, на жаль, створено незначну кількість ігрових завдань для вивчення географії. За цих обставин педагог вимушений напрацьовувати авторські педагогічні розробки. Творчим колективом колегіуму створено тренажери «Країни Європи» та «Географічні хрестики нулики».

Earthcam.com - на порталі зібрана колекція вебкамер, встановлених у всіх містах світу, від США до Таїланду. Їх можна використати в 10-му класі при розгляді країн та регіонів. 7 чудес України - всеукраїнський просвітницький 
проект. Його задум - показати Україну з боку не пересічності та унікальності в природному та історико-культурному форматі. А головна мета - формування привабливості країни як для зовнішнього, так i внутрішнього туризму. Відеофільми можна показувати учням на уроках в межах програми 8-9-х класів. Seterra Online - одна 3 найбільш захоплюючих та популярних географічних вікторин у світі. На сьогоднішній день існує понад 70 безкоштовних додатків, наводимо перелік деяких 3 них: «Прапори світу. Вікторини», «Geography Essentials», «Моя Україна», «Мапа світу. Гра Пазли», «Столиці світу. Вікторина», «Міста», «Вгадай місто по фото», «Країни та столиці», «Тест 3 географії Прапор - країна» та інші.

Граючись, можна у цікавий спосіб запам'ятати розташування країн та їх столиць, пам'ятки, прапори, номенклатуру від найбільш визначних географічних об' єктів до найдрібніших. Програма підійде для засвоєння таких категорій знань: материки та частини світу; найбільші країни в світі або в межах окремого материка; столиці країн і найбільші міста; річки, озера, моря; острови; прапори окремих країн.

Ethermap - достатньо новий інструмент, який допоможе у створенні онлайнкарт. Тут можна обмінюватися картами, вносити доповнення, редагувати все, просто надавши учням посилання. Для допитливих варто запропонувати учням створити разом карту цікавих місць для прогулянок в будь-якому місті, написати про все коротку інформацію та додати фото. Атлас пазлів National Geographic. Кожна з колекцій пазлів $є$ онлайн-картою континенту або країни, містить багато неймовірних історій. Такого типу завдання допоможуть закріпити вивчене у 611-х класах.

На порталі Національного географічного товариства представлений великий вибір інтерактивних завдань. Карти, за допомогою яких можна здійснювати віртуальні мандрівки. В цьому ж розділі Earthpulse знайомить нас 3 проблемами населення. Ресурс доречно використати в 8-му класі при розгляді теми «Населення світу». На сьогодні також доступна бета-версія National Geographic Education, де $\epsilon$ величезна колекція відео- та фотоматеріалів. Перш за все, при нагоді стане конструктор інтерактивних карт. Використовуються добірки різних онлайн-ресурсів 3 готовими презентаціями та відео для полегшення опрацювання тем учнями.

Під час організації дистанційного навчання з усіх предметів, в тому числі і 3 географії, перед вчителем та учнями постає низка проблем, які ускладнюють роботу. По-перше, недостатне технічне забезпечення (мала кількість гаджетів в сім'ї, коли всі працюють або навчаються дистанційно), по-друге, недостатня потужність інтернету (якщо учні або вчителі в умовах карантину знаходяться за містом, у віддалених регіонах, - це унеможливлює використання сервісів та платформ), по-третє, слабка підготовка вчителів та учнів у використанні платформ, сервісів, по-четверте, значне перевантаження роботою вчителів (вчителю доводиться навчатися самому, навчати учнів, організовувати навчання, готувати навчальні матеріали, перевіряти надіслані роботи, готувати та проводити відеоуроки - тобто навантаження значно збільшується), по-п'яте, перевантаження учнів (перегляд та вивчення навчального матеріалу, виконання 
завдань згідно розкладу, участь у відеоконсультаціях, багато часу біля гаджетів, недотримання санітарних норм). Окремою проблемою стає адекватне оцінювання знань учнів, адже підготовані тести, перевірочні роботи учні виконують за допомогою різних джерел знань, спілкуються між собою, списують, а проконтролювати це неможливо. Досить складно провести онлайнопитування, коли приймає участь 36 учнів класу. Те саме стосується й онлайнтестів. Альтернативним варіантом оцінювання знань 3 географії може бути підготовка завдань, відповіді на які не знайдеш в інтернеті. Маються на увазі завдання на виявлення закономірностей, здійснення аналізу, формування висновків, встановлення причинно-наслідкових зв'язків. Підготовка таких завдань вимагає від вчителя ще більше часу на роботу. 


\title{
ВИКОРИСТАННЯ СЕРВІСІВ WЕВ 2.0 В ОСВІТНІЙ ДІЯЛЬНОСТІ 3 МЕТОЮ СОЦІАЛІЗАЦІЇ УЧНІВ
}

\author{
Бойко Рита Миколаївна, \\ директор \\ Тавричанського ОКЗЗСО ім.О.Гатила
}

Освітня діяльність сьогодні зазнає значних змін, що зумовлено новими вимогами до членів суспільства і зміною освітньої парадигми. Якщо раніше основною задачею освіти вважалась передача знань, умінь і навиків учням, то сьогодні «перед освітою виникло складне двоєдине завдання: вона повинна осучаснюватися на основі новітніх технологій через широке впровадження у навчально-виховний процес IКТ, а також - формувати в молоді риси, необхідні для успішної самореалізації в інформаційному суспільстві після завершення навчання в школі чи університеті»[1, с.12]. Ці завдання педагоги мають розв'язувати якісно, адже, як підкреслює В.Г.Кремень, «якісна освіта - це та освіта, яка найефективніше готує людину до життя і діяльності в сучасних умовах, яка найбільшою мірою слугує розвиткові особистості, розвитку кожної людини» [1, с.12].

Нові задачі породжують необхідність конструювання нового змісту освіти, методів, форм і засобів. Проблемою засобів навчання займалися такі вчені та науковці як А. Алексюк, Ю. Бабанський, В.Гриценко, І. Лернер, М. Махмутов, Н.Морзе, А.Семенова, М. Скаткін, В. Онищук та ін. Засоби навчання за Н.В.Морзе поділяють на інформаційні засоби (підручники i навчальні допомоги); дидактичні засоби (таблиці, плакати, відеофільми, програмні засоби навчального призначення, демонстраційні приклади); технічні засоби навчання (аудіовізуальні засоби, комп'ютер, засоби телекомунікацій, відеокомп'ютерні системи, мультимедія, віртуальна реальність).

В якості нових інформаційних засобів доцільно використати так звані сервісів web 2.0, вперше описані у статті Тіма О‘Рейлі „Що таке web 2.0”. Використання соціальних сервісів web 2.0 в якості засобів освітньої діяльності лежить в центрі уваги статті Є. Патаракіна [3].

Вважаю, що, правильно застосовуючи розроблену методику викладання правознавства та історії за допомогою сервісів web 2.0, як засобу навчання,

можна значно підвищити ефективність навчального процесу та пізнавальну активність учнів.

Виходячи з вищезазначеного, визначила такі завдання:

вивчити наукову літературу з даної теми;

3'ясувати можливість використання

сервісів web 2.0 при викладанні історії;

розробити власні конспекти уроків, сценарії 3 використанням сервісів web 2.0 та застосувати їх на практиці; 
перевірити ефективність застосування на уроках та позакласних заходах сервісів web 2.0 на власному досвіді;

удосконалити навички роботи з сервісами web 2.0 іншими засобами.

Використання сучасних веб-сервісів та технологій web 2.0 у навчальному процесі є цікавим та ефективним засобом сприяти підвищенню мотивації до предмета. Соціальні сервіси - це мережеве програмне забезпечення, що підтримує групові взаємодії. Тому застосовую сервіси web 2.0 на практиці під час уроків правознавства.

Освоєння нових засобів веде не просто до того, що ми можемо вирішувати нові завдання, але і міняється наш світогляд, який дозволяє нам бачити світ 3 нової точки зору. Сповідуючи доступність, відкритість, інтерактивність і колективізм, соціальні сервіси web 2.0 стають природним освітнім середовищем, доцільність використання яких в навчальних цілях не викликає сумніву.

На основі пошукових двигунів нового покоління можна побудувати свої власні індивідуальні або колективні пошукові групи. Пошук можна адаптувати до певної тематики і до певного співтовариства [5].

За допомогою web 2.0 можна організувати наступну колективну діяльність:

- спільний пошук необхідної інформації за алгоритмом;

- створення і спільне використання медіа-матеріалів (фотографій, відео, аудіо записів, онлайн стінівки);

- спільне редагування i використання в мережі текстових документів, електронних таблиць, презентацій і інших документів;

- спільне редагування і використання карт і схем.

Існує ряд інструментів навчання, які прийшли 3 традиційного навчання, i залишатимуться обов'язковими постійно. Спілкування багатоплановий процес встановлення і розвитку контактів між людьми, що спрямовані на обмін інформацією, сприймання та розуміння іншого, орієнтуючись на певну тактику і стратегію взаємодії. Засоби спілкування не $\epsilon$ сталими. У цьому процесі чільне місце займають технології web 2.0, які дозволяють: забезпечити простоту у спілкуванні та співпраці всіх учасників навчального процесу за допомогою мережних технологій, створення засобів колективного спілкування та обміну знаннями; реально впровадити особистісноорієнтовані технології навчання за умов докорінної зміни ролі вчителя 3 основного джерела отримання знань до фасилітатора навчального процесу. Фасилітація - стиль педагогічного спілкування, який передбачає полегшену взаємодію під час спільної діяльності учнів та вчителів; не нав'язлива допомога групі чи окремій людині в пошуку способів виявлення розв'язування проблем, налагодженні комунікативної взаємодії між суб’єктами діяльності [2].

На уроках застосовую наступні форми організації роботи 3 використанням сервісів web 3.0:

1) вивчення теми уроку учнями самостійно або в парах 3 допомогою алгоритму та гіперпосилань на необхідний матеріал на сайті чи блозі. 
Це ж стосується і виконання певного завдання. Роль учителя при цьому спрямування роботи, корекція діяльності учнів;

2) використання на уроці мультимедійних можливостей сервісів, що виконує роль наочного посібника. Наприклад, за допомогою LearningApps створюю дидактичні посібники. Lino - дозволяє залучити учнів до створення під час уроку стіннівки. Застосування цих сервісів не вимагає якихось спеціальних знань;

3) використання Miro. Це інтерактивна дошка 3 широкими функціональними можливостями. Мiro дозволяє легко працювати 3 різними форматами файлів і організувати їх ручному форматі. Підтримка різних форматів допомагає зібрати все необхідне в одному місці і завжди тримати потрібну інформацію перед очима. Можна запросити на дошку колег чи учнів, щоб і вони поділилися інформацією.

Miro підтримує такі формати файлів і віджетів: картинки, PDF, MS Office, Google Drive, Web-скріншоти, фігури, тексти, стікери, іконки. Створення інтелектуальних карт, хронологічних стрічок, інфографіки, презентацій. Зручна та проста у користуванні допомагає вчителю відстежувати хід уроку та мати всю наочність під рукою. Виклавши на Фейсбук маю простий доступ.

4) проведення різноманітних опитувань, тестувань за допомогою Googl форм дозволяють швидко та у зручний спосіб отримати результати навчальних досягнень учнів. Крім того, ще й статистичні показники результатів опитування. Через блог (сайт) маю можливість відфільтрувати навчальний матеріал,

перенаправити потрібні інформаційні потоки на свій блог, створивши необхідний освітній контент. Технологія створення блогу (сайту) дозволяє розмістити на власних веб-сторінках колекції авторських навчальних матеріалів (аудіо- і відеоматеріали, посилання на потрібні і цікаві сайти, текстові матеріали, задачі, практичні роботи, матеріали для підготовки до уроків та інше). Налаштування блогу дають можливість організувати працю в закритому гурті користувачів, наприклад, тільки колегам або учням i ïx батькам, або індивідуальну роботу з учнями.

Школа перестає бути єдиним джерелом навчальної інформації, відбувається зміна навчального середовища. 3’являються інші «простори», де учням надаватиметься можливість отримувати навички спілкування і співпраці, поведінку в суспільстві. Учень, працюючи в блозі (сайті) набуває навички роботи в команді, вчиться грамотно формулювати думки, вчиться відбирати, аналізувати і представляти інформацію, освоює мережевий етикет. Така зміна концепції навчального середовища може істотно вплинути на розвиток сучасних учнів. На блозі розташовую навчальний матеріал для самостійного вивчення або матеріал підвищеного рівня складності, матеріал для розширення кругозору чи посилання на інші сайти 3 необхідним матеріалом. Інтерактивні тести, опитування, створені за допомогою сервісів Google, дозволять фіксувати результати їх виконання учнями, проводити перевірочні і контрольні роботи дистанційно. Для підтримки спілкування 3 учнем на сторінках блогу розміщуються гіперпосилання на сервіси, що здійснюють цю підтримку (чат, 
голосова і відозв'язок) або використовуються можливості вбудованих додатків, - гаджетів.

Майже у кожного учня є безцінний гаджет: телефон чи планшет, який я використовую в ході уроку. Даю їх власникам індивідуальні чи групові пошукові завдання, які вони з завзяттям виконують.

У позакласній діяльності широко застосовую власний канал YouTube на якому знаходяться створені фільми з виховною та навчальною метою. Таким чином, під час заходу та уроків маю можливість демонструвати відео 3 каналу не хвилюючись за наявність флешки. До кожного фільму 3 виховної тематики долучилися учні, наприклад, «Що ми знаємо про ВІЛ чи СНІД», «Рок та герої», «Безпека води» та інші. На каналі маю і наробки 3 навчальної діяльності, які застосовую на практиці. На власному сайті та на Фейсбуці маю сторінки свого класу, де викладаються основні події мого класу та якщо потрібно роблю посилання на канал.

Зацікавити учня предметом можемо тільки наблизившись до них та зрозумівши, що саме для них є цінним. Застосовуючи сервіси web 3.0 ми не тільки зацікавлюємо навчанням учнів, а також соціалізуємо їх, що є одним із пріоритетів сучасної освіти.

\section{Література}

1. Кремень В.Г. Якісна освіта в контексті загальноцивілізаційних змін / Кремень В.Г.// Освіта України №89, 28 листопада 2006 року. - С.12.

2. Козяр, М. М. Використання сервісів web 2.0 у навчальній діяльності студентів вищих навчальних закладів [Електронний ресурс] / М. М. Козяр. Режим доступу http://www.nbuv.gov.ua/portal/Soc_Gum/Vldubzh/2009_3/Statti/21.pdf

3. O'Reilly, T. What Is Web 2.0: Design Patterns and Business Models for the Next Generation of Software [Електронний pecypc] / O'Reilly Tim. - Режим доступу : http://oreilly.com/pub/a/web2/archive/what-is-web-20.html?page=1», 2017. $126 \mathrm{c}$.

4. Соловяненко, Д. В. Ключевые принципы Веб 2.0 [Электронный ресурс] / Д. В. Соловяненко. - Режим доступа : http://www.nbuv.gov.ua/articles/KultNar/ knp100t2/knp100t2_147-151.pdf.

5. Сало, О. В. Соціальні сервіси Веб 2.0 як засоби освітньої діяльності [Електронний ресурс] / О. В. Сало. - Режим доступу : http://www.rusnauka.com/ 29_DWS_2009/Pedagogica/53885.doc.htm. 


\section{ВИКОРИСТАННЯ ДЕБАТІВ У ВИКЛАДАННІ СУСПІЛЬНИХ ДИСЦИПЛІН}

Галан Ольга Миколаївна

Комунальний заклад вищої освіти

«Луцький педагогічний коледж»

Волинської обласної ради

\section{Курчаба Олександр Свгенійович \\ викладач суспільних дисциплін, \\ Комунальний заклад вищої освіти \\ «Луцький педагогічний коледж» \\ Волинської обласної ради}

У Давній Греції Сократ свідомо провокував суперечки, називаючи себе при цьому «повитухою істини». Відомий філософ мав на увазі, що продовжує ремесло своєї матері - повитухи. Сучасні регламентовані дискусії, дебати активно стають частиною освітнього процесу.

Перед закладом вищої освіти постає завдання побудови освітнього процесу в чіткому взаємозв' язку з досягненням компетентностей, що задаються державним стандартом. Це в свою чергу актуалізує потребу впровадження сучасних методик, технологій, форм та засобів навчання, які зможуть допомогти навчати, розвивати та виховувати сучасну особистість.

На думку багатьох вчених (Т. Крамарова, Є. Орєшина, Сун Лей, Д. Стейнберг, А. Шнайдер, М. Шнурер, О. Фрілі, В. Фостер, О. Франківська та ін.) такою сучасною педагогічною технологією може виступити технологія дебатів.

У новітній педагогічній думці постає нагальна потреба змінити ставлення до дебатів і розпочати розглядати їх не лише як інтелектуальні змагання та участь у дебатних турнірах. Дебати як педагогічна технологія мають значно ширші освітні можливості. Дебати розвивають дуже важливі навички i вміння, необхідні в сучасному світі: вміння критично мислити та аргументувати власну точку зору, аналізувати та переконувати, спираючись на докази, ставити запитання та шукати на них відповіді, приймати виважені рішення $[5,112]$.

Дебати $\epsilon$, безумовно, педагогічною технологією, тому що відповідають визначенню, даному Н. Д. Хміль: «Педагогічна технологія - комплекс послідовних дій трансляції теоретичних знань у практичну реалізацію функціонування цілісного педагогічного процесу, що забезпечують можливості саморозвитку особистості педагогів і учнів, результати втілення якої можна вимірювати поетапно та бачити динаміку, як розвитку особистості, так i колективу».

Ми вважаємо обгрунтованим віднесення дебатів до інноваційної педагогичної технології.

Сьогодні інноваційні педагогічні процеси стали важливим стимулом розвитку освіти та мають потребу в науковому осмисленні. 
Мета дебатів за цією методикою - не переконати всіх присутніх в одному правильному рішенні, а максимально висвітлити проблемне питання 3 різних сторін, щоб кожна людина могла сама для себе зробити виважені висновки. Хто переможе - визначає журі, яке також проходить навчання спеціальній методиці оцінювання. Остання має чіткі критерії та розроблена таким чином, щоб максимально знівелювати суб'єктивність.

Суспільні дисципліни $€$ «благодатним грунтом» для використання педагогічної технології дебатів. Адже процес викладання економічних, культурологічних, філософських, історичних дисциплін передбачає розгляд питань, які не мають однозначних відповідей. Застосування технології аргументованої суперечки можливе як фрагментарно, у вигляді дебатної вправи, так і використовуючи певний формат дебатів. Можливе використання таких вправ:

$\begin{array}{cl}\bullet & \text { пошук найбільшої кількості аргументів і контраргументів до певної } \\ \text { тези; } & \text { «бої півнів»- короткі дебати на прості теми; } \\ \bullet & \text { - }\end{array}$ партії» для обговорення проблеми [1].

У разі застосування дебатів як виду заняття, доцільно використати певний алгоритм підготовки та проведення, який становить п'ять основних послідовних етапів: орієнтація, підготовка до проведення дебатів, власне дебати, обговорення дебатів, післядія.

Орієнтація включає у себе обгрунтування теми, вибір формату, пояснення ролі гравців та аудиторії, критерії оцінювання, можливі варіації теми та ін.

Стосовно етапу підготовки, дебатна гра вимагає опрацювання великого обсягу інформації, і він набагато більший того мінімуму, що пропонує навчальна програма. Дебати сприяють не тільки накопиченню обсягу знань, а й розумінню глибини та складності матеріалу, який вивчається. Використання даної педагогічної технології сприяє не лише засвоєнню нової інформації, а й розвитку критичного мислення.

Таким чином, у процесі перших двох етапів дебатів вирішуються такі завдання:

- засвоєння термінологічних знань;

- знайомство з джерельною базою .

Етап проведення - процес власне дебатів. Дебати проводятся строго за правилами, які передбачають зіткнення протилежних точек зору. Спочатку участниками жеребування (або за згодою) виявляють позиції: ствердження чи заперечення. Далі дебати проводяться за затвердженим регламентом. Спікери кожної команди (ствердження та спростування) роблять спробу переконати нейтрального суддю в тому, що їх точка зору - наибільш правильна. Для цього вони не просто виступають із промовами, а й спростовують аргументи протилежної сторони. Після кожного конструктивного раунду дебатів проводиться перехресне опитування спікерів. 
Рефлексія дебатів передбачає: опис, аналіз і конструктивну критику, ятельности, фиксацію бистісних змін школярів, рекомендації із урахуванням їх виявлених особистісних змін.

Отанній етап дебатної технології - післядія. Мотивом здійснення «післядії» має стати бажання відстоювати власну думку і надалі, розвиток навиків критичного мислення [2].

Таким чином, дебатуванню як педагогічній технології властиві не тільки такі критерії як технологічність, алгоритмічність, відтворюваність, але й що найважливіше - гарантована ефективність. Дебатна технологія дозволяє вирішити основні завдання у викладанні суспільних дисциплін - підготувати інтелектуальний, критично мислячий потенціал демократичного суспільства: ерудованих, із високою культуроюта та гнучким мисленням, цілеспрямованих, упевнених, вільних від стереотипів громанян.

\section{Список використаної літератури}

1. Зима О. Прийоми педагогіки: дебати як стратегія. Освітній портал. : вебсайт. URL: http://www.osvita.org.ua/articles/813.html

2. Імжарова 3. Дебати як педагогічна технологія. Освіта.иа : веб-сайт. URL: http://osvita.ua/school/method/technol/369/.

3. Навчання через дебати: різноманіття поглядів: адаптований переклад 3 анг. / А. Шнайдер, М. Шнурер; за заг. ред.. О. І. Пометун; пер.: Г. Гупан, Т. Клекота. К.: БФ «Вчителі за демократію та партнерство», 2009. 320 с.

4. Нікора А. Методичні аспекти використання дебатів у навчанні студентівісториків. Науковий вісник Миколаївського начіонального ун-ту ім.В. О. Сухомлинського. Педагогічні науки : збір- ник наук. праць. Миколаїв: МНУ імені В. О. Сухомлинського, 2016. 348 с.

5. Сокол I., Сопіна О., Свириденко І. Застосування технології дебатів для розвитку ключових компетентностей учнів Психолого-педагогічні проблеми сільської школи : зб. наук. пр. Уманського державного педагогічного університету ім. Павла Тичини. Умань : ВПЦ «Візаві», 2017. Випуск 57. С.112114. 


\title{
СТВОРЕННЯ ЗДОРОВ'ЯЗБЕРЕЖУВАЛЬНОГО СЕРЕДОВИЩА В ЗАКЛАДАХ ДОШКІЛЬНОЇ ОСВІТИ: МЕТОДИЧНЕ ВИРАЖЕННЯ
}

\author{
Гаращенко Лариса Василівна \\ к.пед.н., доцент кафедри дошкільної освіти \\ Київський університет імені Бориса Грінченка (Україна, м. Київ)
}

Незаперечним є той факт, що здоров'я - основа життєдіяльності особистості. Створення у закладі дошкільної освіти здоров’язбережувального середовища значною мірою впливає на збереження, зміцнення і формування здоров'я дитини.

Ми повністю поділяємо думку О. Богініч, що створення у закладі дошкільної освіти здоров'язбережувального середовища передбачає організацію всіх процесів життєдіяльності дітей відповідно до закономірностей побудови освітнього процесу, ефективності вибору засобів і методів виховного впливу на дітей $з$ урахуванням їх потреб, інтересів, індивідуальних особливостей та потенціалу кожної дитини [1]. Ефективне зміцнення здоров’я дітей дошкільного віку в умовах закладу дошкільної освіти неможливе без урахування компонентів здоров'язбережувального середовища (комунікативно-знаннєвий, аксіологічномотиваційний, оздоровчо-діяльнісний, госеологічно-розвивальний), комплексне дотримання яких сприяє покращенню здоров’я дітей і залежить від якісної підготовки педагогів [2].

Створення здоров’ язбережувального середовища в кожному конкретному закладі дошкільної освіти залежить від певних факторів.

У першу чергу, це ціннісне і відповідальне ставлення педагогів до проблеми здоров'язбереження дітей, а також світоглядне переосмислення пріоритетності фізкультурно-оздоровчої роботи. Важливо, щоб педагоги розуміли, що здоров’я - це прерогатива самої людини, iї відповідальності перед собою, вихованцями, родиною, суспільством. Принагідно зазначимо, що здоров'я педагога варто розглядати не лише як наскрізну цінність життя, а й професійну цінність.

По-друге, це визнання фізичного виховання як базисної основи здоров'язбережувального освітнього процесу в ЗДО. У фізичному вихованні дітей дошкільного віку якісними показниками є здоров'я, фізичний розвиток, позитивний руховий досвід, підвищення працездатності, що органічно вписуються у загальну мету виховання дітей як співмета чи завдання. Фізичне виховання повинно мати здоров'язбережувальний характер. Фізична культура має включатися у зміст дошкільної освіти і складати основу здоров’я, розвитку і виховання дитини як суб'єкта виховання. Фізичне виховання охоплює ті сторони життя і виховання, що мають вирішальне значення для нормального фізичного розвитку, збереження, зміцнення i формування здоров’я, розвитку рухової сфери, психічного, морального, духовного виховання дітей дошкільного віку. 
Все це стає можливим за умови правильної побудови фізичного виховання як частини цілісного освітнього процесу.

По-третє, це здійснення моніторингу здоров'я та фізичного розвитку дітей. Важливо визначати і фіксувати якісні і кількісні показники засвоєння дітьми рухових дій для визначення рівня фізичної підготовленості та виявлення потенційних можливостей дітей у руховій діяльності. Діагностику та корекцію фізичного розвитку доцільно розглядати в контексті саме педагогічної проблеми, не як короткотривалий захід, а як цілісний процес, органічно включений в освітню систему. Саме на основі результатів моніторингу спрямовується на робота на розвиток потенціалу дітей, окреслюються перспективи роботи з дітьми підготовчої та спеціальної груп здоров'я.

По-четверте, це готовність педагогів здійснювати фізкультурно-оздоровчу діяльність в умовах поліпрограмового простору, використовувати багатий арсенал різноманітних засобів фізичного виховання та оздоровлення дітей. Система фізичного виховання та оздоровлення дітей дошкільного віку виражається у соціально-цільових установках, наявності науково-методичних основ (науково-практичні знання про закономірності, правила, засоби і методи фізичного виховання), наявності програмо-методичних матеріалів, відібраних і систематизованих відповідно до цільових установок. Однак тенденція до погіршення здоров'я дітей, зниження рівня фізичної підготовленості засвідчують, що ця система функціонує недостатньо ефективно. Таким чином, натепер виникла потреба в їі удосконаленні шляхом підбору адекватних засобів i методів навчання дітей фізичних вправ, використання традиційних i нетрадиційних засобів, методів і форм роботи.

По-п'яте, це уміння оцінювати наявні оптимальні умови закладу дошкільної освіти для ефективного використання інноваційних оздоровчих технологій у системі фізичного виховання дітей. Різноманітні оздоровчі технології приваблюють педагогів різноманітністю своїх засобів і новизною. Однак важливо вдумливо, доцільно і систематично їх використовувати в освітньому процесі закладу дошкільної освіти. Необхідно радитися з медиками, психологами, батьками, достеменно знати особливості технології (у чому сутність технології, яка їі мета і результат, яке обладнання потрібно, хто буде проводити, яке місце вона буде займати у розпорядку життєдіяльності дітей, у якій формі фізкультурно-оздоровчої роботи доцільна).

По-шосте, це забезпечення розвивального фізкультурно-ігрового середовища у кожній віковій групі. У процесі проєктування розвивального фізкультурного середовища необхідно враховувати вікові та індивідуальні особливості дітей раннього і дошкільного віку, їх інтереси, потреби і можливості. Особливу увагу слід звернути на умови для самостійної рухової діяльності дітей. 3 метою реалізації індивідуальних інтересів, нахилів і потреб дітей, фізкультурно-ігрове середовище має забезпечити право і свободу вибору дитиною різних видів рухової діяльності.

Крім цього, важливим є якість процесів життєдіяльності дітей упродовж дня в закладі дошкільної освіти та вдома. Маємо на увазі, що життєдіяльність дітей має бути оптимально активною, насиченою, цікавою та безпечною. Якість 
процесів життєдіяльності дітей - це, у першу чергу, достатня рухова активність, оптимальні фізичні навантаження, психологічний комфорт, дотримання екологогігієнічних умов, гігієна приміщення, одягу, сну, якість харчування, культура серверування столу та ін.

Переконані, що формування навичок адекватної здорової поведінки дітей має відбуватися у практичній діяльності, на основі чуттєвого досвіду, в умовах здорового способу життєдіяльності. Шляхами забезпечення рухової активності дітей вважаємо дотримання рухового режиму (проведення різноманітних форм фізкультурно-оздоровчої роботи відповідно до програми та методичних рекомендацій), достатню площу для рухів у приміщенні та на повітрі; врахування часу і місця для самостійної рухової діяльності; включення рухів в усі види діяльності дітей та ін.

Необхідно зробити наголос на тому, що важливо розглядати технологію реалізації фізкультурно-оздоровчої роботи не як формальне повторення різних видів рухової діяльності, а як вдумливий пошук їх варіантів, різноманітних засобів виховного впливу на дітей для ефективного перебігу фізичного розвитку дітей. Надзвичайно важливо встановити довірливі стосунки 3 вихованцями, найти оптимальний спосіб власної поведінки та іiі конструювання, демонструвати дітям приклади ведення здорового способу життя. Роздратованість, авторитарність, нетерпимість можуть стати причиною i власного психологічного дискомфорту.

Таким чином, створення здоров'язбережувального середовища в умовах закладу дошкільної освіти передбачає забезпечення позитивної динаміки у стані здоров'я, фізичного, рухового, особистісного розвитку дітей. Закономірно, що це передбачає ціннісне ставлення вихователів до проблеми здоров'язбереження дітей та їх готовність практично реалізувати завдання фізкультурно-оздоровчого напряму у власній професійній діяльності.

\section{ЛITEPATУРA:}

1. Богініч О. Пріоритети у сфері фізичного розвитку дитини дошкільного віку // Оптимізація фізичного розвитку дитини у вітчизняній системі освіти : монографія / Е. Вільчковський [та ін.]. Запоріжжя: ЗОІППО, 2010. С. 124-148.

2. Лісневська Н. В. Педагогічні умови створення здоров'язберігаючого середовища в дошкільному навчальному закладі : автореф. дис. ... к-да пед. наук: 13.00.08 / Наталія Валентинівна Лісневська; Ін-т проблем виховання НАПН України. Київ, 2016. 36 с.

3. Гаращенко Л. В. Розвиток ідеї здоров'язбереження у фізичному вихованні дітей в дошкільних закладах України (друга половина XX - початок XXI століття) : дис. канд. пед. наук : 13.00 .01 / Гаращенко Лариса Василівна ; Київський університет імені Бориса Грінченка. Київ, 2014. 253 с.

4. Петько Л. В. Гурток «Мандрівники» та формування соціальної активності молодших школярів. Педагогічний альманах : зб. наук. праць / Редкол. В. В. Кузьменко та ін. Херсон : КВНЗ «Херсонська академія неперервної освіти», 2018. Вип. 37. С. 34-39. 
5. Турчинова Г. В. Біологічне пізнання у континуумі особистісної динаміки студентів // Особистість у просторі виховних інновацій : матеріали Всеукраїнської науково-практичної конференції Ін-ту проблем виховання НАПН України, 19 жовтня 2018 р. / [За ред. І. Д. Беха, О. М. Докукіної, Р. В. Малиношевського]. ІваноФранківськ : HAIP, 2018. С. 371-376.

6. Pet'ko Lyudmila. Environmental approach in the formation of social activity in primary school children // Problems of modern science: Collection of scientific articles. - Fadette editions, Namur, Belgium, 2018. Pp. 190-194. 


\title{
ПРОСКТНА РОБОТА ЯК ФОРМА ОРГАНІЗАЦІЇ ІНШОМОВНОЇ ПІДГОТОВКИ МАЙБУТНІХ ІНЖЕНЕРІВ-ЕНЕРГЕТИКІВ
}

\author{
Горбатюк Роман Михайлович, \\ доктор педагогічних наук, \\ професор кафедри машинознавства і транспорту \\ Тернопільський національний педагогічний університет імені Володимира \\ Гнатюка \\ Білан Наталія Миколаївна, \\ старший викладач кафедри гуманітарних дисциплін \\ Відокремлений підрозділ Національного університету біоресурсів і \\ природокористування України \\ «Бережанський агротехнічний інститут»
}

Сучасна галузь енергетики, як і суспільство в цілому, потребує фахівців, здатних інноваційно та творчо здійснювати інженерну діяльність, успішно співпрацювати 3 іноземними колегами, генерувати нові ідеї в іншомовному середовищі, оперативно й правильно приймати нестандартні рішення у професійних ситуаціях, бути вмотивованим i готовим до постійного удосконалення фахового потенціалу та розширення індивідуального кругозору тощо. Формування цих особистісно-професійних якостей здійснюється у процесі здобуття майбутньої професії, невід’ємною складовою якої $\epsilon$ іншомовна підготовка.

Вивчення іноземної мови у технічних університетах має професійноорієнтований характер. Відповідно, при виборі форм організації іншомовної підготовки здобувачів вищої освіти, до уваги береться специфіка майбутньої діяльності за фахом.

Дослідивши професіограму фахівців енергетичної галузі встановили, що проєктування є одним із різновидів інженерної діяльності. У зв'язку 3 цим, вважаємо, що опанування метамови спеціальності 141 «Електроенергетика, електротехніка та електромеханіка» буде результативним, якщо означений процес організовувати у формі проєктної роботи. Це сприятиме міждисциплінарній інтеграції «Іноземної мови за професійним спрямуванням» / «Ділової іноземної мови» 3 предметами за фахом, формуванню іншомовної професійної компетентності студентів.

Під поняттям проєктна робота розуміємо діяльність майбутніх інженерівенергетиків, цілеспрямоване та вмотивоване виконання якої, спрямоване на створення інтелектуально-творчого продукту здобувачами вищої освіти. Даний вид роботи характеризується сукупністю пошуково-дослідницьких, навчальнопізнавальних, предметно-перетворювальних, інтелектуально-інноваційних дій, які $\epsilon$ взаємозалежними та взаємодоповнюючими. У процесі їх виконання, реалізовується поетапне 
створення навчальних проєктів країнознавчого, професійно-орієнтованого характеру, закладаються основи для самонавчання іноземної мови, конструювання нових знань i їх творчого трансформування, розвивається критичне мислення, активізуються рецептивні та продуктивні види мовленнєвої діяльності майбутніх інженерів-енергетиків.

Досягнення успішних результатів проєктної роботи неможливе без урахування індивідуальних особливостей та мовних здібностей студентів. У зв'язку з цим, проєктна робота майбутніх інженерів-енергетиків з іноземної мови розглядається нами з позицій особистісно орієнтованого, диференційованого та компетентністного підходів. Зосередженість на зазначених підходах дозволяє сформувати освітне середовище, сприятливе для іншомовної підготовки здобувачів вищої освіти, не залежно від рівня володіння іноземною мовою, особистісно-професійних інтересів.

Проєктна робота як форма організації іншомовної підготовки майбутніх інженерів-енергетиків грунтується на методі проєктів. Вважаємо, що це один із активних методів навчання, який передбачає виконання «спланованих дій, які походять від серця і знаходять свою реалізацію у соціальному середовищі. У проєктах осмислено поєднується концепція «цінного життя» із «законами навчання» завдяки обміркованим діям. Освітні проєкти є ефективними для формування навичок студентів, оскільки перебіг означеного процесу зумовлює та уможливлює розвиток нових умінь» [1, с. 23]. У межах нашого дослідження такими здатностями є організаційні, пошукові, дослідницькі, інструментальні, репродуктивні, конструктивні, практичні, проєктувальні, комунікативні, креативні уміння.

Беручи за основу типологію навчальних проєктів за Є. Полат, О. Устименко [2, 3], пропонуємо класифікацію проєктної роботи, яка здійснюється здобувачами ОС «Магістр» спеціальності 141 «Електроенергетика, електротехніка та електромеханіка» у межах вивчення навчальної дисципліни «Ділова іноземна мова». У таблиці 1 наочно представлено їі зображення.

Таблиця 1.

Види проєктної роботи майбутніх інженерів-енергетиків з іноземної мови

\begin{tabular}{|l|l|}
\hline \multicolumn{1}{|c|}{ Ознаки проєктної роботи } & \multicolumn{1}{|c|}{ Види проєктної роботи } \\
\hline Спосіб організації і виконання & $\begin{array}{l}\text { Аудиторна, позааудиторна, } \\
\text { особистісно-ініціативна }\end{array}$ \\
\hline Домінуючий вид діяльності & $\begin{array}{l}\text { Пошуково-дослідницька, ігрова, } \\
\text { практична, професійно-орієнтована }\end{array}$ \\
\hline Характер іншомовних завдань & $\begin{array}{l}\text { Репродуктивна, } \\
\text { творча }\end{array}$ \\
\hline Предметно-змістова галузь & $\begin{array}{l}\text { Монопроєктна, міждисциплінарна } \\
\text { Характер координації }\end{array}$ \\
\hline Кількість учасників & $\begin{array}{l}\text { відкритою координацією, } \\
\text { прихованою координацією }\end{array}$ \\
\hline Тривалість виконання & $\begin{array}{l}\text { Індивідуальна, парна, групова } \\
\text { дороткострокова, середньотривала, }\end{array}$ \\
\hline
\end{tabular}




\begin{tabular}{|l|l|}
\hline Спосіб представлення & $\begin{array}{l}\text { Мультимедійна, інформаційно- } \\
\text { комунікативна }\end{array}$ \\
\hline
\end{tabular}

Різновидність проєктної роботи зумовлена тематикою змістових модулів дисципліни «Ділова іноземна мова» та проблематикою іншомовних завдань, які сформульовані не лише з урахуванням програмних вимог, але й індивідуальних особливостей, мовних здібностей студентів, їх можливостей щодо умілого та коректного виконання навчальних проєктів.

Таким чином, проєктна робота $є$ ефективною формою організації іншомовної підготовки майбутніх інженерів-енергетиків, що зорієнтована на самостійну навчально-пізнавальну, науково-дослідницьку діяльність здобувачів вищої освіти, у процесі якої здійснюється формування творчої, ініціативної, компетентної особистості, здатної до саморозвитку, самоосвіти засобами іноземної мови та впровадження інновацій в сфері майбутньої спеціальності.

\section{Список літератури:}

1. Klaus H., Schäfer U. Das Projekt als Lehr-Lern-Form in der Berufsausbildung in Deutschland. Eine Bibliographie für die Jahre 1956 bis 2010. Materialien zur Bildungsforschung. Band 29. Frankfurt am Main, 2011. 220 S.

2. Полат Е. С. Метод проектов на уроках иностранного языка. Иностранные языки в школе. № 2, 2000. С. 3-10.

3. Устименко О. М. Типологія проектів у навчанні іноземних мов. Молодий вчений. № 2 (29). 2016. С. 347-352. 


\title{
ЦИФРОВЫЕ ТЕХНОЛОГИИ ДЛЯ ПОВЫШЕНИЯ КАЧЕСТВА ОБРАЗОВАНИЯ
}

\author{
Дядиченко Елена Абрамовна, \\ доцент, канд. пед. наук \\ Южный федеральный университет \\ Академия психологии и педагогики
}

«Достижения как личностных, так и мотивационных ресурсов невозможно осуществить без построения образовательного процесса, имеющего индивидуальные траектории, т. е. личностно-ориентированного образовательного процесса» [1]. Представителю такого образовательного процесса можно отнести обучение на основе информационнокоммуникационных технологий, поскольку именно такая технология как нельзя лучше отражает все составляющие направления личностно-ориентированного образования. Данные методики образовательного процесса, способны обеспечить индивидуализацию обучения, основанную на личностных способностях обучаемых их интереса, самостоятельности, развития их творческих способностей, доступности к источникам информации, использование компьютерной техники. Иными словами, обеспечение информационно-коммуникационной образовательной среды, которая позволит повышение эффективности и качества образования в педагогическом процессе. «Информационные процессы дали толчок развитию информатизации образования, которая является одним из важнейших условий реформирования и модернизации системы отечественного образования, позволяющей поднять качество образования на высокий уровень» [2].

1 марта 2018 года Президент России Владимир Владимирович Путин выступил с ежегодным Посланием к Федеральному Собранию. В своем выступлении Президент обратил внимание на насущность и неизбежность модернизации страны с помощью тех возможностей, которые предоставляет современная технологическая революция. По его словам, «скорость технологических изменений нарастает стремительно, идёт резко вверх. Тот, кто использует эту технологическую волну, вырвется далеко вперёд. Тех, кто не сможет этого сделать, она - эта волна - просто захлестнёт, утопит» [3].

«С помощью передовых телекоммуникаций мы откроем нашим гражданам все возможности цифрового мира. И это не только современные сервисы, онлайн-образование, телемедицина, что само по себе крайне важно, мы с вами это понимаем. Но, кроме того, люди смогут создавать в цифровом пространстве научные, волонтёрские команды, проектные группы, компании. Для нашей огромной по территории страны такое объединение талантов, компетенций, идей - это колоссальный прорывной ресурс» - пояснил Владимир Владимирович.

Говоря о сфере применения цифровых технологий, Президент помимо прочего перечислил такие сферы и отрасли, как телекоммуникация, 
здравоохранение, развитие гражданского общества, финансы, услуги, логистика, навигация и, конечно же, образование.

«Мы продолжим и активную работу по развитию нашего общего образования, причём на всех уровнях. При этом подчеркну: современное, качественное образование должно быть доступно для каждого ребёнка. Равные образовательные возможности - мощный ресурс для развития страны и обеспечения социальной справедливости», - подчеркнул Президент. - «Нужно переходить и к принципиально новым, в том числе индивидуальным технологиям обучения, уже с ранних лет прививать готовность к изменениям, к творческому поиску, учить работе в команде, что очень важно в современном мире, навыкам жизни в цифровую эпоху. Обязательно будем поддерживать талантливых, нацеленных на постоянный профессиональный рост учителей».

Одним из средств поднятия качества образования с помощью информационных технологий на более высокий уровень, осуществляется с помощью презентационных проектов, разрабатываемых обучаемыми к каждому изучаемому модулю при использовании презентационных программ.

При изучении каждого отдельного модуля по дисциплине использование презентационных проектов позволяет конкретизировать материал, создавать понятные и наглядные, легкоусваемые определения, схемы, таблицы, графики. Обучаемый при использовании презентационных проектов может обратиться за нужной информацией и самостоятельно воспользоваться разработанной презентацией, которая может быть дифференцирована в зависимости от уровня предшествующей подготовки к изучаемому модулю, и повысить уровень познавательных возможностей? а также качество восприятия, изучаемой дисциплины. Используя, презентационное проектирование у обучаемого появляется возможность формировать познавательный интерес, возникают эмоциональные образы изучаемого. «В свою очередь, личностное восприятие изучаемого материала, основанием которого служат индивидуальные способности, находятся в постоянном динамическом развитии, что поднимает восприятия изучаемой дисциплины на более высокую ступень, а отсюда и качество образования» [4]. Презентационные проекты, в приведенной образовательной деятельности, относятся к методической части информационно-образовательной среды, в основном используются в гуманитарных дисциплинах, но спектр их использования не ограничен. Информатизация образования и на еe фундаментальных компетенциях сформированная новая информационно-образовательная среда обладают огромным потенциалом для повышения качества обучения. Данная философия образования будет реализована в полной мере только в том случае, если обучение будет строиться с ориентацией на инновационную модель, важнейшими характеристиками которой являются личностно ориентированная направленность, установка на развитие творческих способностей обучаемых.

В образовательном процессе использование информационных технологий как нельзя лучше будут способствовать осуществлять инновационный подход к учебному процессу, изменив организацию, содержание форму, методы обучения. «Информационные технологии позволят раскрыть индивидуальные 
способности, развить интеллектуальные возможности, его важную роль в образовательном процессе играют современные сервисы сети Интернет» [5].

Автор в своих исследованиях [6],[7] неоднократно делали акцент на то, что одним из преимуществ социальных сетей то, что они являются тем независимым ресурсом, который дает возможность открытости пользователей. Участники образовательного процесса с помощью социальных сетей имеют возможность не только общаться и получать письменную информацию, но имеют видимое пространственное общение. К такому общению можно отнести общение между собой при участии в сетевых дискуссиях по предметным направлениям, общение с преподавателем-консультантом.

Информатизация образования и на ее фундаментальных компетенциях сформированная новая информационно-образовательная среда, обладающая огромным потенциалом для повышения качества обучения.

Россия в рамках национальных целей должна войти в число десяти ведущих стран мира по качеству общего образования, говорится в тексте указа от 21 июля 2020 года № 474 президента России Владимира Путина «О национальных целях развития Российской Федерации на период до 2030 года». «В рамках национальной цели «Возможности для самореализации и развития талантов» ... вхождение Российской Федерации в число десяти ведущих стран мира по качеству общего образования», - отмечается в указе.

Дистанционное обучение - одна из новаций, которую привнесла в нашу жизнь пандемия коронавируса. Южный федеральный университет принял этот вызов и успешно перевел обучение в онлайн-формат. Опыт учебного процесса показал, что использование информационных технологий, использование личностно ориентированной направленности, установка на развитие творческих способностей обучаемых, обладают огромным потенциалом для повышения качества обучения.

\section{Список литературы:}

1. Дядиченко Е.А. Дифференцированное обучение в системе личностно ориентированного образования //Известия высших учебных заведений. СевероКавказский регион. Серия: Общественные науки. 2000. - № 1. С. 105-108.

2. Дядиченко Е.А., Дядиченко О.В. Информационно-коммуникационные технологии как фактор повышения эффективности и качества образования //Проблемы развития науки и образования: теория и практика: Сборник научных трудов по материалам Международной научно-практической конференции 31 августа 2015 г.: в 3 частях. Часть II. М.: «AР-Консалт», 2015 г. -142 с. - ISBN 978-5-9907287-1-4 (Часть II). DOI: 10.18534/2015.08.02

3. Путин В.В. Послание Федеральному Собранию 1 марта 2018 года // http://www.kremlin.ru/events/president/news/56957

4. Дядиченко Е. А., Дядиченко О. В. Научно-педагогическая практика с использованием информационных технологий как вид педагогической деятельности [Текст] // Психология и педагогика XXI века: теория, практика и перспективы : материалы III Междунар. науч.-практ. конф. (Чебоксары, 17 июля 
2015 г.) / редкол.: О. Н. Широков [и др.]. - Чебоксары: ЦНС «Интерактив плюс», 2015. - ISBN 978-5-906626-87-5.

5. Дядиченко Е.А., Дядиченко О.В. Социальные сети в системе высшего образования: мировое образовательное пространство // Наука и мир. - 2015. - № 8 (24), Том 2. С. 47-49.

6. Дядиченко Е.А. Информационно-образовательная среда как фактор повышения качества образования // Современные информационные технологии образования: докл. и сообщ. на научно-методической конференции 11-13 мая 2011 года. -Ростов-н/Д, 2011.

7. Дядиченко Е.А. Использование социальных сетей в образовании //Современные информационные технологии в образовании: тенденции и перспективы развития (СИТО 2012). Материалы XIX научной конференции. 2012. C. 114-115. 


\title{
СОЦІАЛЬНА РОБОТА 3 ПРОФІЛАКТИКИ НЕГАТИВНИХ ЯВИЩ У МОЛОДІЖНОМУ СЕРЕДОВИЩІ
}

\author{
Карпич Ірина Олександрівна, \\ кандидат педагогічних наук, \\ доцент кафедри соціальної педагогіки та соціальної роботи \\ Уманський державний педагогічний університет \\ імені Павла Тичини
}

Сучасні соціально-економічні реформи у державі зумовив зниження рівня життя та цілий ряд антисоціальних проявів: криміналізацію суспільства, трансформацію виховної функції багатьох сімей, дитячу бездоглядність. Проблеми родинного виховання, недостатній рівень профілактики негативних виявів у поведінці молоді, цікавість, допитливість, пошук нових відчуттів у поєднанні з відсутністю критичного ставлення до наркотиків, несформованістю здорового способу життя призводять до збільшення кількості молоді, які курять, вживають алкоголь, наркотичні речовини. Зокрема на особливу увагу заслуговує таке негативне явище як наркоманія. Тому що останніми роками перед українським суспільством гостро постала проблема наркотиків та наркоманії. Все більше і більше молоді - хто з цікавості, а хто «за компанію» (або інших причин) - пробують наркотики. Для багатьох це стає першим кроком на шляху до наркотичної залежності, руйнування особистості, інтелекту, здоров'я, відносини з близькими та суспільством в цілому, до втрати нормальних людських та товариських зв'язків.

У нашій країні боротьба з наркоманією тривалий час велася без широкого розголосу. У популярній літературі питання наркоманії майже не висвітлювали; про цю проблему говорили побіжно, стверджуючи, що соціальних причин для наркоманії у нас немає. Однак наркомани у країні були, i їх кількість збільшувалась 3 кожним роком.

Однією з причин поширення наркоманії є дефіцит знань про наркотики та їх вплив на організм людини. У багатьох, особливо у молоді, неправильне уявлення про наркотики. Люди помиляються, вважаючи наркоманію розвагою, що відносить у світ приємних відчуттів. Вони навіть не підозрюють, яку небезпеку приховують у собі ці “задоволення”, які наслідки спричиняють нешкідливі на перший погляд захоплення, до якої життєвої трагедії вони призводять.

Питанню наркоманії треба приділяти більше уваги у кожній сім’і, школі, у навчальних закладах, на підприємствах, популяризувати знання про шкоду наркотиків серед молоді, передусім у періодичній пресі, на радіо- i телепередачах, науково-популярній літературі. Профілактичні заходи в нашій країні є пріоритетним, оскільки хворобу легше попередити, аніж лікувати.

Перші спроби вживання психоактивних речовин, несвідомі, “за компанію”, 3 цікавості, як спосіб заявити про себе - дорослого, незалежного, сміливого. 
Вживання одного із видів психоактивних речовин $є$ сьогодні обов'язковим атрибутом молодіжної субкультури. Молодіжне середовище $\epsilon$ природним соціокультурним середовищем для однолітків, доступність до якого дорослим обмежена віком, статусом, стилями комунікації. Молодь легше спілкується один 3 одним, краще розуміють потреби свого оточення, $є$ носіями цієї субкультури. Вразливість молодої людини у цей час, потреба донести всім свою особливість і відсутність навиків самореалізації провокують напруженість у стосунках 3 оточенням, а частіше - i конфлікти з однолітками, дорослими.

Психоактивні речовини - речовини, які не лише впливають, а й змінюють свідомість, почуття і сприйняття людини. Такі експерименти згодом призводять до змін у поведінці і свідомості молоді, які лише збільшують кількість його проблем.

Речовини, які вважаються наркотиками, визначені міжнародними конвенціями від 1961, 1971, 1988 років та Національним переліком речовин, що визначаються наркотиками.

Наркотики - це такі речовини, які за трьома критеріями (медичним, соціальним, правовим) завдають величезного лиха, як конкретній особі, так і суспільству в цілому.

Наркоманія - це хворобливе захоплення деякими речовинами, лікам, які паралізують центральну нервову систему.

Профілактика наркоманії - вид соціальної діяльності, що спрямована на проведення соціальних заходів та реалізацію моделей впливу на особистість 3 метою попередження вживання наркотичних засобів, алкогольних напоїв. Грунтується на своєчасному виявленні та виправленні негативних інформаційних, психологічних, організаційних факторів, що зумовлюють відхилення в психічному та соціальному розвитку дітей і молоді, у їхній поведінці, стані здоров'я, а також в організації життєдіяльності й дозвілля.

Зміст роботи соціального працівника з профілактики наркоманії полягає:

- у формуванні установок (відношень, мотивів, моделей поведінки) на життя без наркотиків;

- поширення профілактичної інформації (друкована продукція, засоби масової інформації, міжособистісні стосунки, інші форми соціальної роботи);

- формування умінь і навичок здорового способу життя;

- застереження формування пронаркотичних моделей поведінки;

- організація заходів щодо виконання програми нормальної поведінки;

- превентивна робота $з$ проблем пияцтва, алкоголізму, вживання тютюну серед неповнолітніх і молоді;

- пропагандистські заходи до міжнародних свят, Всесвітніх днів без тютюну, алкоголю, наркотиків.

Ефективність соціальної роботи з профілактики наркоманії залежить від довіри населення, взаємодії 3 органами державної влади, освіти, охорони здоров'я, засобами масової інформації

Важливу роль при профілактиці наркоманії відіграють соціальні працівники, які часто взаємодіють з різними закладами, локальними осередками з метою правильного діагностування причин і сфер загрози наркоманією, а також $\epsilon$ 
співучасниками в конструктивних роботах на користь превентивних дій. Заклади соціальної допомоги, районні центри допомоги сім'ї і регіональні центри соціальної політики - це інституції соціальної допомоги, які підтримують різноманітні локальні дії у цій сфері.

Отже, підсумовуючи все вищесказане, можна зазначити, що не існує одного ефективного методу реалізації соціальної роботи з профілактики негативних явищ у молодіжному середовищі, але одне $\epsilon$ достовірним: чим вищий рівень усвідомлення загроз, які несуть за собою наркотичні речовини, тим менша зацікавленість до їх вживання.

\section{Список літератури}

1. Губенко О. В. Проблема профілактики наркоманії, токсикоманії та алкоголізму : методичні аспекти // Практична психологія та соціальна робота. 2004. - № 12.

2. Костюк О. М. Передумови та негативні наслідки розповсюдження наркоманії // Практична психологія та соціальна робота. - 2004. - № 10. - С. 4 5 .

3. Максименко С. Д. Наркоманія : підходи до профілактики та подолання // Практична психологія та соціальна робота. - 2005. - № 10. - С. 1-3.

4. Орел Г. О. Організація та проведення первинної профілактики наркоманії серед неповнолітніх та молоді // Соціальний працівник. - 2007. - № 10. - С. 2 31. 


\title{
ЗНАЧЕННЯ СОЦАЛЬНОГО ПАКЕТА НА ПІДПРИЕМСТВІ
}

\author{
Моргай Лілія Анатоліївна, \\ доктор філософії, \\ доцент кафедри соціальної педагогіки та соціальної роботи, \\ Уманський державний педагогічний університет \\ імені Павла Тичини
}

Соціальний пакет - це вміст усіх соціальних пільг, гарантій та виплат працівнику підприємства, комплекс зобов'язань роботодавця перед трудовим колективом [2].

Склад і структура соціального пакета визначається як законодавством, так і самим роботодавцем, виходячи з потреб ринку праці та в залежності від можливостей і прогнозних цілей розвитку підприємства.

Існує багато чинників, що впливають на значення соціального пакета. Насамперед, вона повинна відповідати стратегії підприємства, його цілям, стану ринку праці та загальних тенденції на ньому, діючому законодавству, системі оподаткування, розміру компанії та іiі фінансовим можливостям, потребам працівника, рівню кваліфікації працівника та його посади [1].

Щодо структури соціального пакету на підприємстві. Загалом, соціальний пакет поділяється на базовий та мотиваційний. Мотиваційний у свою чергу поділяється на конкурентний та компенсаційний.

Базовий СП у свою чергу виконує: забезпечення умови праці передбачених законодавством; загальнообов'язкове державне соціальне страхування; виплата у повному розмірі належної заробітної плати; надання соціальних пільг і гарантій, передбачених колективним договором.

Конкурентний СП у свою чергу виконує: забезпечення здоров'я; розвиток корпоративної культури; мотивація праці; відпочинок і розваги.

Компенсаційний СП у свою чергу виконує: відшкодування особистих витрат, пов'язаних із роботою (на транспорт, зв'язок, оренду або придбання житла в іншому місці тощо) [4].

Згідно з проведеними соціологічними опитуваннями, для працівників різного рівня пріоритетними у складі соціального пакета є відповідні складові.

Так для топ-менеджерів найбільш бажаним елементом соціального пакета є медична страховка для себе (77\% опитуваних), на другому місці медична страховка для родини $(66 \%)$, і на третьому - безкоштовне навчання (33\%) та абонемент до фітнес-клубу (33\%). Виконавчий персонал віддає перевагу медичній страховці для себе (65\%), далі йде безкоштовне навчання $(59 \%)$ та на третьому місці можливість отримання кредиту на купівлю житла $(35 \%)$ і оплата харчування в офісі (35\%).

За результатами опитування користувачів лише $38 \%$ українців мають соціальний пакет на місці своєї роботи. У той же час, $16 \%$ вітчизняних професіоналів зізналися, що в їхніх компаніях соціальні переваги доступні 
лише обраним співробітникам. Частіше за все компанії включають у свої соціальні пакети такі опції: оплата мобільного зв'язку (44\% респондентів зізналися в цьому), медичне страхування (32\%), оплата транспортних послуг $(17 \%)$, оплата обіду $(15 \%)$, оплата відпочинку (15\%), страхування від нещасного випадку (11\%), оплата професійного навчання (10\%).

Наповнення соціального пакету у різних країнах носить специфічний характер. Обсяги та зміст соціального пакета можуть дуже різнитися та залежати від: особливостей країни, у якій розташоване підприємство; галузі та масштабу діяльності; типу підприємства; особливостей його структури; специфіки діяльності та якісних характеристик вищих управлінських ланок установи [3].

Виходячи 3 наявної статистики, у США вартість соціального пакета коливається в межах $40-50, \%$ від базової заробітної плати. Основний вартісний обсяг соціального пакету у країнах Заходу - до $50, \%$ - припадає на різні види страхування, головним серед яких виступає медичне страхування працівників. У західних країнах простежуються різні методи наповнення соціального пакета, серед яких найбільшого поширення отримали: «Інституційний метод» (або традиційний); програма «Буфет»; «Комплексна програма»; «Система балів»; «Метод гілок».

Надання соціального пакета працівникам регулюється не так жорстко, як питання оплати праці. Це пов'язано 3 варіативністю його складу та добровільним характером його запровадження на підприємствах. Порядок документального оформлення надання соціального пакета працівникам підприємства представлено в таблиці [1].

Забезпечення працівникам соціальними пакетами дає змогу роботодавцю досягати таких цілей: сформувати позитивний імідж і бренд роботодавця на ринку праці; узагальнення особистих цілей співробітника у відповідність зі стратегічними планами організації; орієнтувати працівників на підвищення продуктивності праці, поліпшення результатів діяльності; залучити і утримати компетентних працівників, знизити плинність; поліпшити результати праці за рахунок посилення мотивації працівників та зменшення кількості захворювань; контролювати витрати на робочу силу; оптимізувати витрати на соціальне забезпечення працівників, отримати податкові пільги, зменшити непередбачувані фінансові витрати; поліпшити якість трудового життя, матеріальний добробут найманих працівників і членів їхніх родин; підвищити якісні параметри людського капіталу; поліпшити соціальнопсихологічний клімат в організації [1].

В умовах жорсткості боротьби між великими компаніями за залучення висококваліфікованих працівників спостерігаються тенденції збільшення загальної частки соціальних пільг у компенсаційних пакетах компаній (в окремих компаніях - до 50\% сумарної винагороди) і розширення спектра використовуваних опцій.

Розвинена соціальна політика підприємства вказує на те, що в стратегічних цілях організації присутня не тільки максимізація підприємницького прибутку, але й соціальне забезпечення співробітника, 
розвиток його особистості, i, як показує практика, такі організації виявляються найбільш ефективними, ринково успішними.

Соціальний пакет, окрім вирішення базових потреб персоналу таких, як: житлові, потреби в харчуванні, охороні здоров'я, відпочинку та інші, як інструмент мотивації включає в себе наступні потреби: надання можливості оволодіння новими знаннями i підвищення кваліфікації; подарунки до урочистих подій; організація корпоративних свят і відпочинку; оплата корпоративного одягу; надання службового транспорту; оплата користування службовим мобільним телефоном; публічні винагороди, подарунки, сувеніри відповідно до досягнутих успіхів; оплата навчання дітей співробітників у вищих навчальних закладах; оплата відпочинку дітей співробітників у таборах [3].

Вибір того або іншого елементу соціального пакета залежить від багатьох показників.

По-перше, це труднощі, що виникають при оподаткуванні послуг, які надаються. У зв'язку з цим роботодавець не може оперувати своєю фантазією, включаючи якісь «особливі» опції.

По-друге, це недостатне фінансування.

По-третє, використання соціального пакета повинне відповідати потребам працівників і сприяти підвищенню ефективності їхньої праці.

У зв'язку з цим необхідним є грамотна розробка та впровадження соціального пакета, інформування персоналу про його впровадження та пояснення необхідності й корисності соціального пакета для персоналу.

Отже, висвітливши вмісти соціальних пакетів на підприємствах України та закордону, можна стверджувати, що вони подібні, хоча і мають відмінності. Це пов'язано з багатьма чиниками: соціально-економічними умовами країни, маштабністю самих підприємств та особливостями піклування власників фірм, директорів про працівників установ.

\section{Список використаних джерел}

1. Васильєв В. В. Соціальна робота на підприємстві : навч. посіб. Київ : Видавничий Дім «Слово», 2011. 424 с.

2. Енциклопедія для фахівців соціальної сфери. 2-ге видання. Київ, Сімферополь : Універсум, 2013. 536 с.

3. Мельникова К. В. Соціальний пакет як інструмент матеріальної мотивації. URL http://nbuv.gov.ua/j-pdf/eupmg_2014_1_7.pdf (дата звернення: 03.03.2021).

4. Сергійчук C. I. Компенсаційний пакет: суть та проблеми його ефективного застосування на підприємствах промисловості України. URL: http://www.economy.nayka.com.ua/?op=1\&z=6288 (дата звернення: 03.03.2021).

5. Цимбалюк С. О. Соціальний пакет: сутність, природа та мотиваційна роль. URL: http://ua.z-pdf.ru/7ekonomika/641743-8-socialno-trudovi-vidnosiniteoriya-praktika-zbirnik-naukovih-prac-zasnovaniy-2011-vida-tsya-razi-rik-1-2011kiiv-2.php (дата звернення: 03.03.2021). 


\title{
ОСОБЛИВОСТІ РОЗВИТКУ ЕМОЦІЙНОГО ІНТЕЛЕКТУ ДІТЕЙ ДОШКІЛЬНОГО ВІКУ
}

\author{
Передерій Ольга Леонідівна \\ кандидат педагогічних наук, \\ доцент кафедри дошкільної та початкової освіти, \\ Дніпровська академія неперервної освіти
}

Поняття «емоційний інтелект» вперше з'явилося в 1964 році в роботі М. Белдока «Sensitivity to expression of emotional meaning in three modes of communication». Це явище вивчали У. Пейн , П. Саловей, Д. Майер, Р. Бар-Он, Г. Гарднер, Е. Носенко, Г. Березюк, О. Філатова, Л. Божович, О. Запорожець, В. Котирло, П. Якобсон. Науковці наголошують на тому, що емоційний розвиток характеризується специфікою психічного розвитку, він обумовлений змінами діяльності, в процесі яких відбувається формування емоційних процесів, особливостями взаємодії дитини з навколишнім світом; також значні відмінності спостерігаються в емоційному розвитку дитини на різних вікових етапах $[1,197]$. Емоційний інтелект відіграє значну роль в процесі соціалізації дитини, тому емоційний розвиток дітей дошкільного віку є одним з найважливіших напрямків професійної діяльності сучасного педагога у вихованні дітей дошкільного віку.

Емоційний інтелект - це здатність людини розпізнавати емоції, розуміти наміри, мотивацію і бажання інших людей та свої власні, а також здатність керувати своїми емоціями та емоціями інших людей 3 метою вирішення практичних задач. Емоційний інтелект складається з емоційної ідентифікації, сприйняття та вираження себе, стосується здатності точно сприймати емоції у вербальній та невербальній поведінці інших; здатності використовувати емоції для сприяння мисленню та вирішенню проблем; емоційне розуміння, що означає здатність аналізувати почуття, розрізняти емоції та думати про їх результати; емоційний менеджмент, який має справу зі здібностями, пов'язаними зі збереженням або зміною емоцій $[2,346]$.

Особливості емоційного інтелекту дитини дошкільного віку полягають в тому, що дитина починає опановувати соціальні форми вираження почуттів, розуміти емоції та співвідносити їх зі своєю поведінкою, в неї формуються почуття моральності, почуття починають бути усвідомленими. Виховання дитини на цьому етапі ставить на меті навчити дітей розпізнавати і проявляти свої емоції; допомогти дітям в усвідомленні власних потреб і потреб інших людей; прищепити дітям навички культурного спілкування.

Розвивати емоційний інтелект дитини в закладах дошкільної освіти можна різними засобами, серед них долучення до спільної діяльності, взаємодії, рольові ігри, трудова та творча активність, художня література.

Дошкільний вік $€$ періодом виникнення і розвитку спільної діяльності. Це вміння - результат усвідомлення і прийняття ролі і значущості іншої людини в своїй діяльності. Саме спільна діяльність призводить до якісних змін в свідомості дитини і у дитини з'являються такі риси, як здатність вирішувати проблеми 
шляхом взаємодії з дорослими і однолітками, доброзичливість, тактовність, самоконтроль, вміння враховувати і приймати іншу точку зору $[3,48]$. Дитина вчиться усвідомлювати рівні своїх можливостей, які зростають, опановує вміння проявляти особистісне ставлення і наполегливість в реалізації поставлених задач $[4,13-14]$.

Взаємодія $є$ соціальною за характером, вона виражає зв'язок між особистостями і групами людей. Вона передбачає тривалий або короткочасний, вербальний або невербальний контакт педагога і вихованця, що обумовлює взаємні зміни в їх поведінці та діяльності. Такий контакт реалізується через спілкування, у процесі комунікації учасників навчально-виховного процесу. Також до партнерської взаємодії можна віднести переконання, заохочення, моральну підтримку, організацію ситуації успіху, довіри. I зрозуміло, що будьяка взаємодія є неможливою без емоційного аспекту, передавання інформації потребує емоційного підсилення, так створюються сприятливі умови для розвитку емоційного інтелекту [5, 170-171].

Ігрова діяльність $є$ важливою для розвитку особистості дошкільника. Саме в процесі гри активізується громадське життя дітей, тобто відбувається формування дитячого суспільства. У грі особливо яскраво проявляються індивідуальні особливості дитини, ігрова творчість у дитини може мати різний рівень і залежить від змісту гри, ролі, від взаємин з товаришами. Основа рольової гри - уявна ситуація, що містить в собі сюжет, ролі та пов'язані 3 ними дії. Особливостями рольової гри є дотримання правил, соціальний мотив. Через засвоєння правил рольової поведінки в грі дитина засвоює і моральні норми, укладені в ролі. Діти усвідомлюють мотиви і цілі діяльності дорослих, їх ставлення до подій і явищ суспільного життя, до людей, речей; в грі формується позитивне відношення до різного способу життя людей, до вчинків, норм і правил поведінки в суспільстві. Важливою в процесі гри $\epsilon$ можливість демонстрації як позитивних, так і негативних емоцій, при цьому варто звертати увагу на взаємозв'язок виявлених емоцій і подій. Це створюватиме дітям приклади взаємодії в реальному світі [6].

Результатом будь-якої трудової діяльності $\epsilon$ внутрішне зусилля особистості, що навчає дитину прагнути досягати позитивного результату, дає можливість відчувати радість за здійснене, загальний успіх, почуття задоволеності від проведеної роботи. Творча діяльність розвиває естетичні почуття дитини, формує почуття прекрасного, навчає розуміти поняття «краса». Трудова і творча діяльність дозволяють ефективно розвивати емоційний інтелект за умови комплексного підходу до організації їх проведення в закладі дошкільної освіти.

Твори художньої літератури вчать дітей глибше розуміти себе, свої емоційні відчуття, а також емоції і характер людей, що оточують. Вони викликають співчуття, осуд, гнів, подив, захоплення; під впливом художнього твору діти зможуть розширити і збагатити свій емоційний досвід або змінити колишні ціннісні установки. Роль педагога в даному випадку полягає в навчанні дітей вмінню переносити ці почуття і емоції в реальні ситуації: бачити емоційний стан іншої людини, допомагати, захищати, співпереживати, наслідувати в 
життєвих ситуаціях певного персонажа, виявляти в житті ситуації аналогічні казковим за своєю сутністю. Вивчення впливу засобів художнього твору на розвиток емоційного інтелекту дітей доводить ефективність обраного засобу для розвиток у дошкільнят розуміння власних емоцій, емоційних станів і переживань інших людей. Використання художньої літератури в розвитку емоційного інтелекту дітей дошкільного віку буде ефективним i результативним при дотриманні цілісності, безперервності, системності педагогічного процесу.

Отже, емоції $є$ важливою складовою нашого повсякденного життя, що значно впливають на взаємини 3 оточенням, самовизначення, здатність до співпраці. Пріоритетним напрямком роботи сучасного педагога закладу дошкільної освіти є навчити дитину адекватно сприймати емоції людей, що оточують, використовувати власні емоції для стимулювання мислення, розуміти емоції - тобто знаходити їх причини, бачити взаємозв'язок подій і емоцій, та вчити керувати власними емоціями, це стане грунтовним базисом для формуванням потенційного ресурсу соціальної успішності в довгостроковому плані.

\section{Список літератури:}

1. Шпак М. М. Становлення емоційного інтелекту в дошкільному віці як передумова його розвитку в молодшого школяра. Наукові записки Національного університету "Острозька академія". Серія : Психологія. 2016. Вип. 4. С. 196-205.

2. O'Lievens F. R., Chan D. Practical Intelligence, Emotional Intelligence, and Social Intelligence. In Handbook of Employee Selection. New York: Routledge. 2017. pp. 342-364.

3. Нгуен М. А. Психологические предпосылки возникновения эмоционального интеллекта в старшем дошкольном возрасте. Культурноисторическая психология. 2007. № 3. С. 46-51.

4. Манилюк Ю. Оптимальна модель педагогічної взаємодії у дитсадку. Дошкільне виховання. 2012. №8. С. 11-15.

5. Смолік О. С. Емоційний інтелект і партнерська взаємодія. Дошкільна освіта у сучасному соціокультурному просторі: зб. наук. праць; за заг. ред. О. А. Гнізділової, відпов. ред. Н. В. Ковалевська. Полтав. нац. пед. ун-т імені В. Г. Короленка. Полтава: Видавець Шевченко Р. В., 2017. Вип. 1. С. 167-174.

6. Гиниятуллина Э.Д. Развитие эмоционального интеллекта дошкольника. Universum: Психология и образование: электрон. научн. журн. 2019. № 2(56). 


\title{
ОРГАНІЗАЦІЯ ФІЗИЧНОЇ КУЛЬТУРИ УЧНІВ В ПОЗАКЛАСНІЙ ДІЯЛЬНОСТІ ЗАГАЛЬНООСВІТНЬОЇ ШКОЛИ
}

\author{
Поліщук Віталій Валентинович \\ кандидат наук з фізичного виховання та спорту, доцент \\ кафедра спортивних дисциплін і туризму \\ університет Григорія Сковороди в Переяславі, Україна \\ Гордіснко Олександр Іванович \\ ст. викладач \\ кафедра спортивних дисциплін і туризму \\ університет Григорія Сковороди в Переяславі, Україна
}

\section{Волківський Микола Володимирович}

ст. викладач

кафедра спортивних дисциплін і туризму університет Григорія Сковороди в Переяславі, Україна

Анотація. В статті аналізується проблема ефективності організації фізичної культури учнів. Розглядаються теоретичні засади особливостей та форм організації виховання фізичної культури учнів в позакласній діяльності. Розкривається технологія виховання фізичної культури учнів у позакласній роботі у взаємодії загальнопедагогічних наукових положень та теорії та методики фізичного виховання.

Ключові слова: особливості виховання, позакласна діяльність, фізична культура.

Постановка проблеми. Характерною особливістю фізичного виховання молодших школярів у процесі позакласної роботи є різнобічність його форм. Однією 3 найважливіших форм організації і проведення з учнями початкових класів активного дозвілля $є$ позакласна робота з фізичного виховання, яка сприяє формуванню активної життєвої позиції, організації здорового способу життя, змістовного відпочинку на природі. Під час занять фізичною культурою в позашкільний час учні початкових класів загартовують свій організм, зміцнюють здоров'я, розвивають фізичні якості. Особливі умови позакласної діяльності 3 фізичної культури сприяють вихованню морально-вольових якостей особистості: взаємопідтримки, взаємодопомоги, організованості, дисципліни, принциповості, чуйності й уваги до товаришів, сміливості, стійкості, мужності, почуття відповідальності та організаторських здібностей, необхідних у практичній діяльності учнів і в побуті.

В останні роки науковці акцентують увагу на культурологічних функціях освіти взагалі, навчально-виховного процесу в загальноосвітній школі - зокрема. Усе більшої життєвості набувають наукові ідеї про те, що кінцевий результат 
освіти - це високий рівень культури особистості, де модернізована освіта повинна виховувати активних творців загальної культури суспільства. Стверджується, що школа XXI століття в Україні має створити сприятливі умови для оволодіння кожною дитиною базовими основами культури.

До базових основ культури особистості сучасна наука відносить їі різні види: правову, економічну, політичну, екологічну, художньо-естетичну, фізичну, побутову та інші $[1,5]$. Фізична культура, таким чином, $€$ органічною складовою загальної культури особистості. Закономірно, що „Концепція національного виховання" розглядає фізичну культуру особистості учня (в інтеграції з іншими видами) як одну зі складових частин загальної мети національного виховання [3]. Посилення культурологічних тенденцій у вихованні вимагає відповідного науково-педагогічного обгрунтування ряду проблем фізичного виховання, у тому числі виховання фізичної культури учнів як їхньої особистісної властивості та як цілісного культурологічного явища.

Державний підхід до проблем фізичного виховання, фізичної культури i спорту відтворюють: Закон України „Про фізичну культуру і спорт", „Цільова комплексна програма „Фізичне виховання - здоров'я нації", „Державний стандарт базової і повної загальної середньої освіти". У контексті виховання фізичної культури учнів суттєвим у цих документах $є$ те, що фізичне виховання дітей і молоді розглядається як важливий компонент гуманітарного виховання, всебічного розвитку молодого покоління.

Аналіз останніх досліджень і публікацій. Актуальність проблеми фізичного виховання молодших школярів у позакласній роботі вбачається і в дослідженні ефективності організаційно-педагогічних умов фізичного виховання учнів у процесі позакласної роботи в загальноосвітніх навчальних закладах. Тому стратегічною метою науково-дослідницької роботи $є$ теоретичне обгрунтування, розробка й експериментальна перевірка ефективності організаційнопедагогічних умов фізичного виховання молодших школярів у позакласній роботі загальноосвітніх навчальних закладів і за місцем їх проживання.

Багато авторів присвятили свої праці дослідженню проблем фізичного виховання учнів. Зокрема, аналізувалися організаційно-методичні основи фізкультурно-спортивної роботи 3 учнями, педагогічні умови поліпшення фізичного виховання учнів загальноосвітньої школи, розвиток особистості школяра у взаємодії фізичного та естетичного виховання (Л.Гурман. О.Леонов, Т.Палагнюк, Т.Ротерс та ін.), виховання в учнів здорового способу життя, запобігання шкідливим звичкам засобами фізичної культури (О.Дубогай, С.Закопайло, С.Кондраткж, В.Кузьменко А.Турчак та ін.), досліджувалися проблеми формування позитивного ставлення учнів до занять фізичною культурою та спортивної діяльності, потреби фізичного вдосконалення дітей 3 послабленим здоров'ям, виховання відповідального ставлення до свого здоров'я, свідомої дисципліни засобами фізкультурно-оздоровчої роботи (О.Зварищук, В.Лесик, А.Сватьєв, Н.Солопчук, С.Столітенко та ін.).

Проведений аналіз сучасних науково-педагогічних джерел, вивчення практики фізичного виховання в загальноосвітній школі дають підстави стверджувати, що фізична культура учня як інтегративне, цілісне явище, як його 
особистісна властивість досліджувалася дуже мало. Недооцінка або звужене розуміння культурологічного спрямування фізичного виховання негативно позначається на управлінських функціях, технології здійснення фізичного виховання, залученні до нього суб'єктів шкільної діяльності, його ефективності.

Мета дослідження. Обгрунтувати особливості виховання фізичної культури учнів в позакласній діяльності.

Результати дослідження. На виховання фізичної культури учнів як складової їхнього загального культурного розвитку впливає чимало чинників: економічних, кадрових, педагогічних (методичних, управлінських), наукових тощо. Один із них - обгрунтованість у педагогіці суті поняття „фізична культура учня" як цілісного явища (а не тільки в його окремих проявах). Це є необхідним, на наш погляд, тому, що:

a) без розкриття названого поняття позакласна практична діяльність ряду суб'єктів виховання фізичної культури учнів (не фахівців) не має достатніх науково-педагогічних орієнтирів і мотивації їх участі у фізичному вихованні учнів (учителі-предметники, класні керівники, керівники предметних гуртків, «клубних об'єднань і т. ін.);

б) фізична культура як явище загальної культури нерідко ще і в наш час недооцінюється, а межі ії культурного впливу інколи звужуються.

На нашу думку „фізична культура учня - це сукупність інтегрованих фізичних $\mathrm{i}$ духовних властивостей, що характеризують віковий та індивідуальний рівень його досягнень у фізичній підготовленості, фізичному розвитку, фізкультурній освіченості і $€$ органічною частиною особистісної загальної культури та всебічного гармонійного розвитку".

Поняття „фізична культура учня" як складне та інтегроване явище накладає відбиток на технологію ії виховання в загальноосвітній школі. Цілеспрямовано фізична культура учнів виховується через організовані форми навчання та позакласну діяльність.

Позакласна діяльність відкриває широкі можливості для виховання фізичної культури учнів, але при ії організації на наукових засадах та при наявності умов для творчого здійснення. Через позакласну діяльність забезпечується різнобічність знань учнів про фізичну культуру і спорт, розширюється коло джерел інформації, збагачується фізкультурно-спортивна поінформованість учнів. Задовольняються індивідуальні запити, потреби дітей, розвивається їхня рухова активність фізичні якості й здібності. Відбувається становлення переконань, ціннісних орієнтацій учнів щодо власного здоров'я та його зміцнення засобами фізичної культури і спорту, здорового способу життя, цікавого дозвілля, у якому значне місце займає фізкультурно-оздоровча i спортивна діяльність. Формується звичка до систематичної участі в масових і групових формах фізичного виховання.

Цей вік займає особливе місце в розвитку учня, що різнобічно розкриває психолого-педагогічна література $[2,4,5]$. Головне - це вік переходу від дитинства до дорослості, коли формуються особистісні ціннісні орієнтації, здійснюється вибір життєвих зразків, застосовуються норми й вимоги, що панують у світі дорослих (позитивні або негативні). 3 одного боку, це вік 
сприятливих можливостей для становлення учня як особистості, здійснення його соціалізації (засвоєння соціального позитивного досвіду й норм суспільства). 3 іншого - це складний, суперечливий період становлення учня, коли його самоутвердження внаслідок впливу різних чинників (брак досвіду, негативне середовище, неврівноваженість, неадекватні методи та відсутність належних умов виховання та ін.) набуває часом негативних, асоціальних форм і виявів свідомості та поведінки. Тому дуже важливо, щоб підліток у період активного становлення своїх міркувань, суджень, знань, ставлення до навколишнього світу був задіяний у позитивно формувальних видах діяльності, щоб його інтереси були адекватні наявному в суспільстві позитивному світу цінностей, щоб виробленню цих цінностей сприяли певні життєві зразки, позитивні приклади тощо. Фізична культура і спорт як явище культури мають у цьому контексті значні виховні можливості, котра школа має активізувати.

Позакласна діяльність дає широкий простір для використання різноманітних форм і засобів впливу на свідомість, почуття і волю учнів при здійсненні фізичного виховання, для цілеспрямованого застосування їх у вихованні фізичної культури.

Адміністрація школи забезпечує загальне управління процесом виховання фізичної культури, доводить до колективу школи державні закони, постанови, рішення регіонального рівня 3 питань фізичного виховання, турбується про створення необхідної навчально-матеріальної" бази для занять фізичною культурою і спортом, надає допомогу в проведенні позакласних заходів різним суб'єктам навчально-виховного процесу, стимулює учнів школи засобами заохочення до занять фізичної культурою і спортом, координує дію різних суб'єктів виховання фізичної культури тощо.

Учитель фізичної культури як професійно підготовлений спеціаліст за допомогою усіх форм навчальної та позакласної роботи закладає фундамент фізичної культури, розкриває учневі способи оволодіння необхідними знаннями, навичками й уміннями, методикою розвитку фізичних якостей для зміцнення здоров'я, забезпечення здорового способу життя, активної праці. Спільно 3 директором школи (його заступниками) він планує роботу з фізичного виховання у школі, забезпечує проведення уроків 3 фізичного виховання, здійснює безпосереднє організаційне й методичне керівництво позакласною діяльністю 3 фізкультурно-оздоровчої та спортивно-масовою роботою, забезпечує участь команд школи взмаганнях міста, району, надає методичну й організаційну допомогу іншим учителям, класним керівникам, учнівському активу, учням.

Шкільні медичні працівники (лікар, медсестра) безпосередньо вивчають стан здоров'я учнів, здійснюють необхідні профілактичні та оздоровчі заходи, проводять пропагандистську роботу з питань збереження та зміцнення здоров'я, надають консультації учням, педагогам, батькам тощо.

Шкільний психолог, соціальний педагог проводять різноманітну роботу 3 вивчення вихованості учнів, розробляють необхідні робочі матеріали для проведення діагностування (вивчення рівня інтересів, розуміння здорового способу життя, ставлення до куріння, вживання наркотиків, організації дозвілля) тощо. 
Класний керівник здійснює широке коло функцій у вихованні фізичної культури учнів, він $є$ одним із головних суб'єктів їі виховання в позакласній діяльності.

Діяльність усіх суб'єктів виховання фізичної культури учнів повинна будуватись як спільна, що скеровується загальною метою, з усвідомленням кожним суб'єктом своїх функцій у досягненні цієї мети. Дії адміністрації школи, педагогів та учнів мають бути узгодженими, здійснюватися у взаємодії.

\section{Висновки.}

1. Виховання фізичної культури учнів повинно спиратися на сучасний науково-педагогічний грунт, який відбиває нові (демократична національні, культурологічні) тенденції в освіті, інтеграцію знань педагогіки, психології, культурології, теорії і методики фізичного виховання, необхідність культурологічного підходу у фізичному вихованні.

2. При вихованні фізичної культури також повинні застосовуватися й принципи навчання, розроблені дидактикою. Це пов'язано з тим, що фізична культура учня у своєму змісті має такі компоненти, як знання, свідомість і т.д. Використовуються й спеціальні науково-методичні принципи, які стосуються навчання учнів фізичних вправ, рухових дій тощо.

3. Загальноосвітня школа має широкі можливості для виховання фізичної культури учнів у позакласній діяльності, що стає реальним при ії організації на наукових засадах та наявності необхідних умов. Обов'язкова причетність до цього процесу кожного суб'єкта педагогічної діяльності, а не тільки вчителя фізичної культури.

Отже, позакласні заняття допомагають батькам і педагогам у вирішенні важливих питань по вихованню дітей: виховання морально-вольових, а також розвитку рухових якостей.

Накопичений досвід дозволяє визначити певні рекомендації в цьому плані.

По-перше, всі заходи повинні бути об'єднанні у цілеспрямовану комплексну систему, що допоможе на високому емоційному рівні реалізувати ідею співпраці тіла i розуму, налагодити міжпредметні зв'язки i, врешті-решт, сформувати уявлення про розумний спосіб життя. Це, так би мовити, третій, вищий рівень комплексації засобів (фізичні вправи, природа, гігієна) фізичного виховання, якщо за перший взяти комплексний урок, а за другий - тижневий мікроцикл.

По-друге, для періодичного впливу на емоційну сферу учнів задля підтримання їхньої постійної зацікавленості до самовдосконалення елементи цієї системи доцільно розмістити в такій послідовності:

1) дні здоров'я - перший тиждень жовтня;

2) некласифікаційні змагання 3 включенням вправ, що були предметом домашніх завдань на літо - перші тижні листопада;

3) вечір спортивної слави - кінець грудня;

4) веселі старти сімейних команд - лютий і березень;

5) свято спорту і мистецтва - середина травня.

Регулярні заняття фізичною культурою не тільки поліпшують здоров'я $\mathrm{i}$ функціональний стан, але і підвищують працездатність і емоційний тонус. Однак 
варто пам'ятати, що самостійні заняття фізичною культурою не можна проводити без лікарського контролю, i, що ще більш важливо, самоконтролю.

\section{Список літератури}

1. Бех I. Система фізичного виховання має формувати в учнів загальнолюдські гуманістичні цінності // Фізичне виховання в школі. - 1998. № 1. - С. 3-6.

2. Вільчковський Е. С. Теорія і методика фізичного виховання дітей дошкільного віку : навч. посіб. / Е. С. Вільчковський, О. І. Курок. - Суми : Універсальна книга, 2004. - 428 с.

3. Концепція національного виховання. Схвалена Всеукраїнською педагогічною радою працівників освіти 30.06.1994 р. // Рідна школа, 1996. - №6. - C. $18-25$.

4. Круцевич Т. Ю. Теорія і методика фізичного виховання : [підруч. для студ. вищ. навч. закл. фіз. виховання і спорту] / за ред. Т. Ю. Круцевич. - К. : Олімпійська література, 2008. - Т. 2. - 366 с.

5. Подласый И.П. Педагогика: Новый курс. Учебник для студ. пед. вузов: В 2 кн. - N4.: Гуманит. изд. центр ВЛАДОС, 1999. - Кн. 2: Процесе воспитания. - 256 c.

6. Психологія і педагогіка життєтворчості: Навч.-метод, посібник /Ред. рада: В.М.Доній, Г.М.Несен, Л.В.Сохань, І.Г.Срмаков та ін.- К., 1996. -792 с.

7. Сембрат С. В. Ігрова спрямованість фізичної підготовки дітей молодшого шкільного віку : Дис. ... канд. наук з фізичного виховання і спорту : 24.00 .02 / С. В. Сембрат. - Переяслав-Хмельницький, 2003. — С. 180-190.

8. Семигал О. М. Хортинг в системі виховання фізичної активності дітей : Навчально-методичний посібник для тренерів і спортсменів / О. М. Семигал. Полтава : Знання, 2010. - 247 с. 


\title{
ВИКЛИКИ СУЧАСНІЙ СИСТЕМІ ОСВІТИ В УМОВАХ ВСЕСВІТНЬОЇ ПАНДЕМІЇ СОVID 19. ЗАЛУЧЕННЯ IHTEPHЕT РЕСУРСІВ ТА IНШI АСПЕКТИ ДИСТАНЦІЙНОГО ТА ЗМІШАНОГО ВИКЛАДАННЯ ІНОЗЕМНОЇ (ІСПАНСЬКОӤ) МОВИ
}

\author{
Сухорська Наталія Ігорівна \\ Асистент кафедри французької філології \\ Львівський національний університет ім. І.Франка
}

В кінці 2019 - на початку 2020 року людство стикнулося з проблемою раніше небачених масштабів: пандемією коронавірусу.

Безпосередньо Україну ця проблема зачепила в середині березня 2020 року і одразу поширилася на всі сфери життєдіяльності, в тому числі й на освіту. Був оголошений карантин. Якби це трапилося років 20 тому, то 3 великою ймовірністю навчальний процес довелося б зупинити. Проте в сучасних умовах, при наявності Інтернету, програм для віддаленого конференц-зв'язку та інших сучасних засобів комунікації та ресурсів, забезпечити якісний рівень викладання стало цілком реально.

3 початком карантинних обмежень як студенти, такі і викладачі були змушені шукати альтернативні способи комунікації та проведення занять, оскільки навчання вживу стало неможливим. У цій статті не буде наведено ідеальний спосіб організації дистанційного навчання, однак буде описано низку важливих аспектів, що вплинули на процес здобуття освіти в умовах пандемії.

Звісно, під час дистанційного навчання ми залежимо від цілої низки факторів, на які ми не завжди можемо вплинути. Це, перш за все, якісний Інтернет зв’язок, наявність технічних засобів (комп'ютерів, ноутбуків, телефонів, камер, мікрофонів і т.д.), відповідного програмного забезпечення і т.д.

На сьогоднішній день існує безліч різних програм призначених для відеоконференцій. Деякі з них вимагають попередньої реєстрації та створення акаунту, а деякі - ні. Однією 3 найзручніших платформ для налагодження комунікації між студентами та викладачами виявився Zoom. Практика показує, що навіть при наявності інших платформ чи каналів комунікації більшість все ж обирають саме цю платформу.

Одним із позитивів дистанційної комунікації є можливість залучення різних, у тому числі і Інтернет ресурсів, для проведення заняття. Зокрема, під час проведення занять 3 іспанської мови, ми маємо можливість не лише використовувати підручники, але швидко і якісно забезпечити студентів аудіоматеріалами, що $є$ дуже важливо при вивченні іноземної мови, задіяти Інтернет сторінки, які містять цікаві інтерактивні завдання для вивчення іноземних мов. Серед інших хотілося б виділити такі Інтернет ресурси як: https://www.videoele.com/Curso.html, https://www.profedeele.es, https://aprenderespanol.org/videos/espanol-episodios-1.html. 
Перший [1] містить короткі відео розроблені спеціально для тих, хто вивчає іспанську мову. Цікавим $\epsilon$ те, що за допомогою цього сайту студент може не лише вивчити певні граматичні конструкції чи час, але й ознайомитися 3 культурою, звичаями Іспанії, помилуватися ііі містами, більше дізнатися про побут мешканців цієї країни. Окрім того, кожний відео-сюжет має транскрипцію та вправи для самоконтролю. Усі відео поділені на 4 рівні, які відповідають Загальноєвропейській Рекомендації з мовної освіти [2]: А1, А2, В1, В2, що є дуже зручним під час підбору матеріалу для того чи іншої групи студентів i дає можливості врахувати їхній рівень знань.

Наступний Інтернет ресурс [3], створений спільними зусиллями викладачів іспанської мови всього світу цікавий тим, що дав можливість пошуку матеріалу за різними критеріями: граматика, лексика, рівень володіння мовою, пісні, культура, мистецтво і т.д. Тут можна знайти як професійне пояснення іспанської граматики 3 великою кількістю письмових та аудіо вправ для закріплення матеріалу, так і пісні відомих виконавців з використанням лексики чи граматики на певну задану тему. Цей сайт цікавий тим, що тут, на відміну від попереднього, можна знайти завдання рівня $\mathrm{C} 1$ та $\mathrm{C} 2$.

I нарешті останній [4], але не менш цікавий на наш погляд Інтернет ресурс, який ми розглянемо містить майже сотню серій, кожна близько 15 хвилин, які пов'язані між собою спільними героями та побудовані за принципом від найпростішого до складнішого.

Звичайно, що окрім позитивних моментів, які забезпечує нам дистанційне навчання існує цілий ряд недоліків. Це на сам перед, спосіб ідентифікації особи, адже викладачу важливо бути впевненим з ким він веде бесіду на основі якої може здійснюватися оцінювання. Звідси і з'являється вимога до доповідача вмикати камеру під час розмови з викладачем чи з іншими учасниками онлайнзаняття.

Іншою великою проблемою є забезпечення реалізації об'єктивного контролю та дотримання принципу академічної доброчесності в умовах дистанційного навчання. На наш погляд для цього слід пропонувати більших креативних завдань, встановлювати певні обмеження у часі і т.д..

При організації дистанційного чи змішаного навчання слід враховувати рекомендації МОН України [5].

Ну і звичайно, жодні гаджети не здатні нам замінити живе спілкування.

\section{Список використаних джерел:}

1. Електронний ресурс. - Режим доступу https://www.videoele.com/Curso.html

2. Електронний ресурс.

https://uk.wikipedia.org/wiki/Загальноєвропейські_рекомендації_3_мовної_освіти

3. Електронний ресурс. - Режим доступу https://www.profedeele.es.

4. Електронний ресурс.

Режим доступуһttps://aprenderespanol.org/videos/espanol-episodios-1.html. 
5. Електронний ресурс. - Режим доступу https://mon.gov.ua/ua/osvita/vishaosvita/rekomendacij-shodo-vprovadzhennya-zmishanogo-navchannya-u-zakladahfahovoyi-peredvishoyi-ta-vishoyi-osviti 


\title{
ОБГРУНТУВАННЯ МЕТОДІВ, ВИКОРИСТАНИХ У ПІДГОТОВЦІ МАЙБУТНІХ УЧИТЕЛІВ ФІЗИЧНӦ̈ КУЛЬТУРИ ДО ОРГАНІЗАЦЇ̈ ПОЗАКЛАСНОӤ РОБОТИ 3 ТУРИЗМУ
}

\author{
Чалій Людмила \\ Рівненський державний гуманітарний університет, Україна
}

Мамчур Світлана

Рівненський державний гуманітарний університет

Бутенко Тетяна

Рівненський державний гуманітарний університет

Наше дослідження стосується деяких аспектів проблеми професійної підготовки фахівців фізичної культури.

Проведено теоретичний аналіз загальної проблеми формування готовності майбутніх учителів фізичної культури до організації позакласної роботи. Аналіз психолого-педагогічної та науково-методичної літератури показав спрямованість цілої низки наукових досліджень на вирішення проблеми готовності майбутніх фахівців до професійної діяльності $[1,2,3]$.

Однак ми виявили, що у педагогічній теорії недостатньо напрацювань щодо підготовки майбутніх учителів фізичної культури до організації позакласної роботи з туризму.

Сутність та зміст позакласної роботи з туризму можна визначити як систему заходів спортивного-оздоровчого, навчального та виховного напрямів, що базується на можливостях туризму як дієвого засобу залучення учнів до підтримання здорового способу життя через участь у заняттях туристсько-краєзнавчих гуртків, розширення світогляду учнів через участь у туристських подорожах та масових туристських заходах, надання можливостей спортивного зросту для зацікавлених обраним видом спорту [4, С.43].

Аналіз сучасного стану сформованості готовності майбутнього учителя фізичної культури до організації позакласної роботи з туризму зорієнтував нас у пошуку моделі підготовки. Як стверджує І.Н. Сабатовська, «модель фахівця - це опис того, до чого має бути придатним фахівець, до виконання яких функцій він підготовлений та якими якостями володіє; моделі дозволяють відрізняти одного фахівця від іншого, а також рівні (якості) підготовки фахівців одного й того ж типу; модель виступає системоутворючим чинником для відбору змісту освіти i форм його реалізації у професійній діяльності» [5].

Наша модель відображає інтегроване соціальне замовлення суспільства та держави, компоненти процесу навчання: загальнонаукові принципи та підходи, мету та завдання навчання, структуру та зміст, діяльнісний компонент та результативну оціночну складову. У структурі моделі ми виділили: 
концептуальний, змістовий, технологічний та результативно-корекційний блоки. Етапами реалізації моделі визнано: підготовчий, операційний, діагностико-результативний (рис.1).

Вибір того чи іншого методу залежить від специфіки конкретного академічного заняття. Варто відзначити серед використаних нами у процесі формування готовності майбутніх учителів фізичної культури наступні методи навчання у вищій школі: на теоретичних заняттях - лекція-проблема, лекціяпрезентація, лекція-диспут, лекція-консультація; на практичних заняттях мозковий штурм, круглий стіл, ситуаційні ігри, тренінги, захист власних проектів, міні-змагання на різних технічних етапах, ділові ігри; в позааудиторній діяльності - інформаційний пошук в інтернет-мережі, інтерактивне спілкування, волонтерська діяльність, організація спортивно-масових заходів, співпраця 3 організаціями та установами туристського профілю за вибраним напрямком роботи.

Під час аудиторних занять вирішення проблемної ситуації відбувається через проблемне завдання, тому нами використовувалися такі методичні прийоми: проблемна доповідь «Знайти причини», діалог по темі «Допомога потерпілому у поході», диспути-протиріччя «Демократизм чи авторитаризм керівника походу, що краще?», кросворд «Топографічна головоломка», аналіз конкретної ситуації «Початок походу: $\epsilon$ проблеми», заплановані помилки. Таким чином стимулюється пошукова діяльність майбутніх учителів фізичної культури, орієнтуючи процес формування готовності на творчий розвиток, що досягається лише на основі практики та мислення у проблемних ситуаціях (невід'ємна складова педагогічної діяльності).

За допомогою сучасних комп'ютерних технологій ми впроваджуємо інтерактивні методи навчання, що, як відомо, передбачають активну взаємодію викладача та студента - інтерактивна гра «Виживання в умовах незапланованої ночівлі», відеоконференції «Мій досвід участі у походах», «Краєзнавчі родзинки» тощо.

На практичних заняттях процес навчання забезпечується такими методами: робота у малих групах по підготовці подорожі, фронтальні технології («Мікрофон», мозковий штурм, кейс-стаді), навчання в грі (імітаційні ігри (кожен учасник відтворює своє похідне доручення), рольові ігри «Якби мене призначили...»), навчання у дискусії «Обираю позицію», ток-шоу «Безпека чи екстрим - що я вибираю у туризмі?», дебати. Проходить відтворення майбутньої професійної діяльності через постановку проблемних завдань та вирішення їх через спільні дії квазіпрофесійного характеру. Майбутні учителі вчаться спільно працювати, швидко реагувати, приймати рішення, планувати та відтворювати суттєві моменти. 


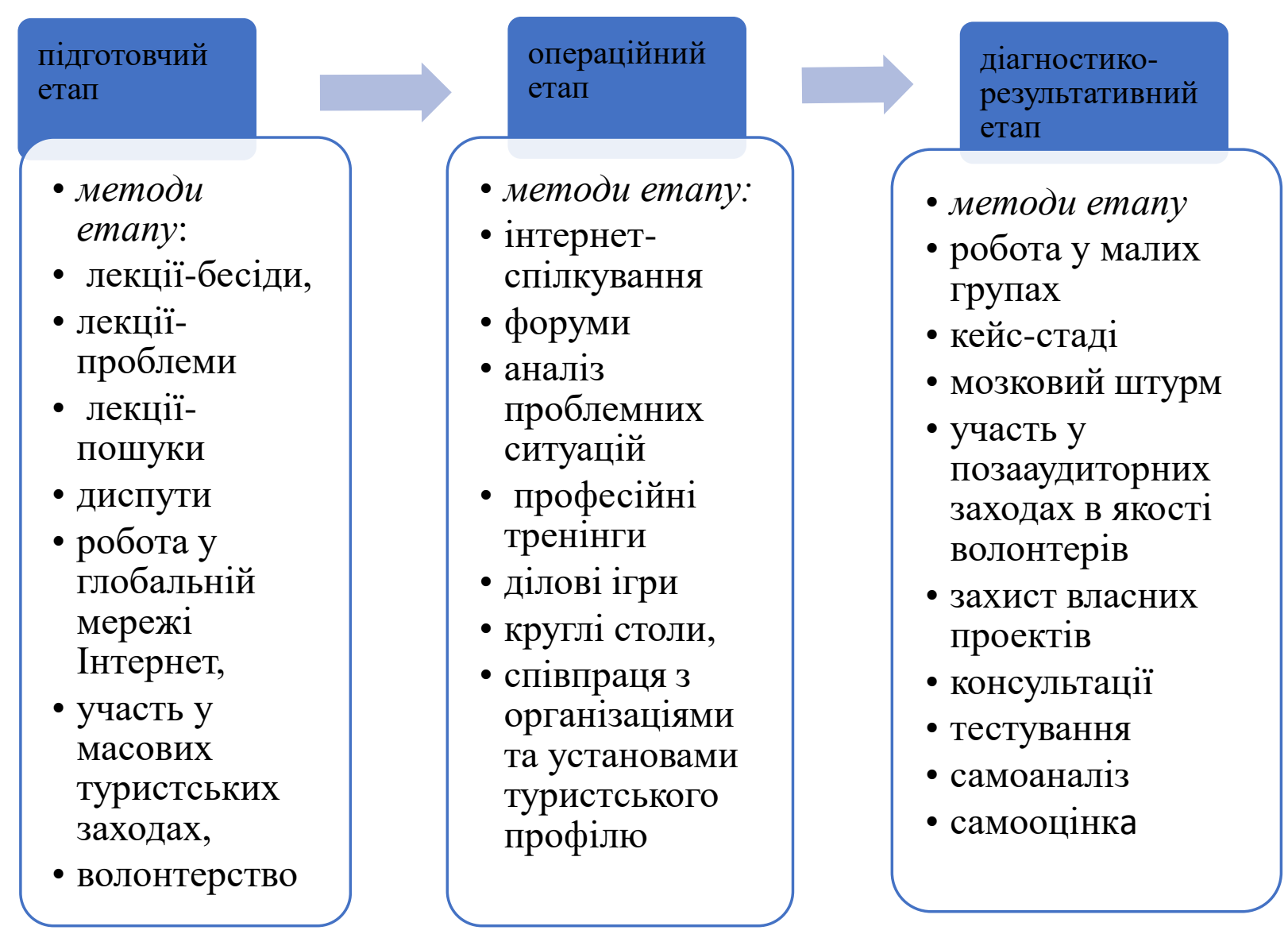

Рис. 1. Методи підготовки майбутнього учителя фізичної культури до організації позакласної роботи з туризму.

Активність кожного студента узгоджується із загальною дисципліною, 3 толерантним відношенням до інших, 3 необхідністю контролювати свій емоційний стан та відчувати себе підлеглим керівнику - якості майбутнього учителя фізичної культури, необхідні для позакласної роботи з туризму.

На наше переконання активні методи (організація спортивно-масових заходів, волонтерська діяльність, співпраця 3 організаціями та установами туристського профілю за вибраним напрямком роботи, інтерактивне спілкування) забезпечили формування стійкого інтересу до туристичної діяльності, мотиваційних установок до організації позакласної роботи з туризму.

\section{References:}

1. Атамась О. А. Формування готовності майбутніх учителів фізичної культури до впровадження технологій оздоровчого фітнесу: автореф. дис. ... канд. пед. наук: 13.00.04; Нац. пед. ун-т ім. М. П. Драгоманова. Київ, 2015. 20 с.

2. Захаріна С. А. Професійна підготовка майбутніх учителів фізичної культури до позакласної та позашкільної оздоровчо-виховної роботи: теорія та методика: монографія. Запоріжжя: Класич. приват. ун-т, 2012. 439 с. 
3. Сущенко Л. П. Теоретико-методологічні засади професійної підготовки майбутніх фахівців фізичного виховання та спорту у вищих навчальних закладах: автореф. дис. ... д-ра пед. наук: 13.00.04; Ін-т педагогіки і психології проф. освіти АПН України. Київ, 2003. 45 с.

4. Чалій Л.В. «Формування готовності майбутніх учителів фізичної культури до організації позакласної роботи з туризму» : дис. ... канд. пед. наук: 13.00.04; Східноєвропейський національний університет імені Лесі Українки, Луцьк. $290 \mathrm{c}$.

5. Сабатовська I. С. Модель особистості та соціальна спрямованість діяльності майбутнього фахівця. Проблеми сучасної педагогічної освіти. Педагогіка i психологія. 2013. Вип. 38(2). С. 20-26. URL: http://nbuv.gov.ua/UJRN/pspo_2013_38\%282\%29_6 


\title{
ЖАһАНДАНУ КОНТЕКСІНДЕГІ ИНКЛЮЗИВТІ БІЛІМ БЕРУ
}

\author{
Шашкенова Асель Женисовна \\ Екінші курс магистранты \\ Е.А. Бөкетов атындағы Қарағанды университеті \\ Жолмаганбетова Диана Кайратовна \\ Екінші курс магистранты \\ Е.А. Бөкетов атындағы Қарағанды университеті \\ Қарағанды облысының «№2 арнайы мектеп-интернаты» КММ \\ Тәрбиеші

\section{Дахбай Бейбитхан Дахбаевич} \\ Медицина ғылымдарының докторы, профессор \\ Е.А. Бөкетов атындағы Қарағанды университеті
}

Мақалада қызметтің жеке стилін қалыптастыру шарттары талданады: оқыту мен тәрбиеге диагностикалық, сараланған және жеке тәсілдер; педагог пен білім алушы қызметінің жеке стилінің сәйкестігі; білімді меңгеру деңгейінің эволюциясы (репродуктивті - эвристикалық - креативті). Сондай-ақ, жаһанданудың әртүрлі деңгейлері көрсетілген, білім беруді дамытудағы жаһандану тенденциялары және әртүрлі категориялары бар оқыту модельдері қарастырылған. Жаһандық білім беру әртүрлі деңгейлерде - жаһандық мегасистема (планетарлық) деңгейінде, Ұлттық білім беру жүйелерінің өзара ісқимылы мен өзара байытылуы, мемлекетаралық, өңіраралық байланыстар мен халықаралық ынтымақтастық және нақты білім беру жүйелері (мектептер, сыныптар, орталықтар, университеттер және т.б.) деңгейінде түсіндіріледі.

Жаһандық білім жаңа мыңжылдықтағы әлемді басқару жүйесіне әлемдік білімнің әсерін қамтамасыз етеді. Британдық зерттеуші Р. Робертсон: «жаһандық тұжырымдама әлемнің қысылуына да, бүкіл әлем туралы хабардарлықты күшейтуге де қатысты: белгілі бір жаһандық тәуелділікке де, XX ғасырдағы жаһандық тұтастықты түсінуге де қатысты», - деп атап өтті. Жаһандық білім ақпараттың үлкен әлемін ашады және әлемдік деңгейде табысты және құзыретті қызмет үшін үлкен мүмкіндіктер береді; «әлем адамы» болуды қамтамасыз етеді. Білім беру қазіргі заманғы педагогикалық ғылым мен тәжірибені дамытудың маңызды бағыты ретінде танылды, оның мақсаты адамды мазасыз, өзгермелі және өзара тәуелді әлемде өмірге, қазіргі жаһандық проблемаларды шешуге дайындау болып табылады, олардың бірі әр түрлі білім беру қажеттіліктері бар балаларды жүзеге асыру мүмкіндіктерін ашатын инклюзивті білім беру болып табылады.

«Жаһандық білім беру» ұғымы әртүрлі деңгейлерде түсіндіріледі:

- жаһандық мегасистема (планетарлық), ұлттық білім беру жүйелерінің 
өзара іс - қимылы мен өзара байытылуы, мемлекетаралық, өңіраралық байланыстар мен халықаралық ынтымақтастық деңгейінде;

- нақты білім беру жүйелері деңгейінде (мектептер, сыныптар,

орталықтар,

университеттер және т.б.), қазіргі білім беру стандарттарына, жаңа ақпараттық және оқыту технологияларына сәйкес планетарлық ойлау мен сананы дамытатын интернационалдық (халықаралық) білім беру мазмұнының деңгейінде.

Жаһандық білім беру - бұл ұлттық білім беру кеңістіктері мен жүйелерінің жиынтығы ғана емес, бұл жеке тұлғаны дамыту мүмкіндіктерін кеңейтуге бағытталған ұлттық және әлемдік білім беру саясатының мақсаттары белгіленген және іске асырылатын ерекше «мегасистема».

А. Лиферов: «халықаралық білім беру саясатын үйлестіру, ұлттық білім беру жүйелерінің өзара жақындасуы, толықтырылуы және өзара тәуелділігі, оларды ұлттықтан жоғары институттармен реттеу негізінде қол жеткізілген іс әрекеттерді синхрондау, ұлттық даму жүйелерінің өздерінің мемлекеттік шеңберлерін біртіндеп дамыту және бірыңғай білім беру кеңістігін қалыптастыру тенденцияларының пайда болуы болашақ міндеттерін іске асырудың тиімді нысаны ретінде білім берудің жаһандануы халықаралық интеграцияның жаңа мүмкіндіктерін ашады» деп айтқан. Р. Паул жаһандық білім беру трендтері болашақ ұрпақтың жаңа ойлау (сыни) және жаңа өмір салтын қалыптастыруға, жаңа жағдайда ойлауға және әрекет етуге оқытудың инновациялық тәсілдерін іздестіруге әкелетінін баса айтады. Бұл студенттердің стандартты емес жауаптары мен зерттеу қызметін іздеуге, шығармашылықты, тәуелсіздікті, кәсіпқойлықты, жауапкершілікті дамытуға мүмкіндік беретін сыни ойлау. Сыни ойлауды дамыту оқушының жеке ерекшеліктерін ескере отырып, оның ic - әрекетінің «жеке стилінің» пайда болуын анықтайтын ерекше педагогикалық жағдайларды, инновациялық модельдер мен технологияларды құруды талап етеді.

Зерттеулерді талдау қызметтің жеке стилін қалыптастыру шарттарын белгілеуге мүмкіндік береді: оқыту мен тәрбиелеуге диагностикалық, сараланған және жеке тәсілдер; педагог пен білім алушы қызметінің жеке стилінің сәйкестігі; білімді меңгеру деңгейлерінің эволюциясы (репродуктивті эвристикалық - креативті). Жасалған оқыту моделін сынай отырып, Д. Колб оқытудың төрт фазасын сақтау білім алушылардың сапаларын, қабілеттері мен іскерліктерін дамытуды қамтамасыз ететінін атап өтті: нақты тәжірибе - жаңа тәжірибені қабылдау қабілеті; рефлексивті бақылау - тәжірибені түсіндіру қабілеті; деректі концептуализация - бұл біртұтас түсіну, бақылау деректерін дәйекті, логикалық теорияға құратын ұғымдар мен өкілдіктерді дамыту мүмкіндігі; белсенді эксперимент - бұл теориялық идеяларды шешімдерді қабылдау, проблемаларды шешу үшін пайдалану мүмкіндігі, бұл жаңа тәжірибе алуға әкеледі. Жеке іс - әрекет стилінің дамуы бейресми, бұлтты оқытумен қамтамасыз етіледі, онда балалар идеяларын іске асырады, тәуелсіз ашылулар жасайды және таным арқылы оқыту үшін қайтадан күреседі» (Сеймур Пайперт); әлемге әр түрлі бұрыштардан, өнертабыстардан, тапқырлықтан, шығармашылық 
пен білімге деген құштарлықтан, қызығушылықтан, жеке оқу траекториясынан (сұраныс бойынша оқыту); терең маманданудан (әмбебаптықтан) құтылу; әлемнің әр түрлі бұрыштарынан, өнертабыстарынан, тапқырлығынан, шығармашылық пен құмарлықтан, қызығушылықтан инструктивализм (Сеймур пайперт термині); лектор виртуалды кейіпкерге айналған кезде білімнің сандық формаларға ауысуы - нейротехнологиядағы психотехнологиялардың өзгеруі атмосферамен, сезіммен, эмоциямен жұмыс. Жаһандық білім беру тренді ретінде оқытудың жаңа үлгілері бастауыш мектепте инклюзивті білім беруді іске асыру жағдайында білім алушылардың жеке білім беру траекторияларын құруға мүмкіндік береді [1].

Білім берудің жаһандық тенденциялары арасында білім берудің жаңашылдығы, сабақтастығы, дербестігі, барлығына білім алу құқығын қамтамасыз ету, білім алуға әлеуметтік - экономикалық факторлардың әсері, оқушылардың қызығушылықтарын қанағаттандыруға және қабілеттерін дамытуға бағытталған оқу және ұйымдастырушылық іс - шаралар спектрінің ұлғаюы; «орташа оқушыға» бағдарланудан кету және т.б. дарынды балалар мен жастарға қызығушылықты арттыру, оқу процесінде олардың қабілеттерін ашу және дамыту ерекшеліктері және білім беру құралдары; дамуында ауытқулары бар балаларға, мүгедек балаларға білім беру үшін қосымша ресурстарды іздеу. Дәл осы соңғы екі тренд ұсынылған мақаланы өзектендіреді, өйткені өркениетті жол бойынша қоғамның дамуын жүргізуге қабілетті адам капиталын молайтуға бағдарланған [2].

Білім беруді дамытудағы жаһандану үрдістері және қазіргі заманғы технологияларды іздестіру ерекше білім беру қажеттіліктері бар балалардың әлеуметтік интеграциясы үшін алғышарттар жасайды. Аталған санаттағы балалардың қалыпты дамуы мен білім алуын қамтамасыз ету проблемаларын түбегейлі шешу арнайы білім беру жүйесіне қатысты мемлекеттік саясатта ғана емес, сонымен қатар инклюзивті білім берудің жаңа институттарын дамытуда да айтарлықтай өзгерісті талап етеді. Ұлттың зияткерлік әлеуетін қалыптастыру жөніндегі мемлекеттік саясат неғұрлым талантты және дарынды балаларға, жастарға ұдайы назар аударуды және жан - жақты қолдауды талап етеді, бұл білім алушылардың осы санаты үшін жеке білім беру шарттарын жобалауды болдырмауды негіздейді.

М.C. Ашилова XXI ғасырдағы білім беру жүйесінің сын - тегеуріндері мен трендтерін талдай отырып, олардың шетелдік және ресейлік білім берудегі ерекшеліктерін ашады. XXI ғасырдың білім беруінің басты ерекшелігі, оның пікірінше, оқу процесінің жаңа міндеті: мұғалім (ұстаз) өзі әлі білмейтін нәрсені үйретуді үйренуі керек. Мұндай мәселені шешудің шарттары жаһандық үрдістерді ескеру болып табылады: фундаментализация, ақпарат беру, саралау, интеграция, инсталляция, аксиологизация. У. Глассер «жеңілмейтін мектептер» кітабындағы білім беру жүйесін дамытудың негізгі резервін мидың қайталама функциясын - шаршауды емес, оның бастапқы функциясын - ойлауды дамыту деп санайды. Осы стратегияға сәйкес білім беру жүйесінің мақсатты функциясын алынған білім көлемін олардың сапасын жақсарту міндетіне, оқушылар мен студенттерді қаруландыру міндетіне, сондай - ақ білім беру әдістеріне 
қарапайым көбейту міндетінен қайта бағыттау - бұл күрделі, талап етілетін мәселе ұзақ мерзімді күш.

Білім берудегі жетекші тенденция ретінде фундаментализация білімнің тез өсіп келе жатқан көлеміне байланысты, сондықтан оқыту дайын ақпарат жиынтығын зерттеуге емес, құрылымдық принциптерді түсінуге, «абстрактілі» теорияларды, олардың арасындағы қатынастарды дамытуға бағытталған теория білімнің біртұтас, тұрақты және ықшам формасы болып табылады [3].

Ғаламдық кеңістіктегі ең көп таралған Білім беру модельдері:

Бала білім беру процесінің объектісі (субъект ретінде емес) ретінде әрекет ететін білім берудің «ақпараттық» (немесе трансляциялық) моделі;

«Қалыптастырушы» (немесе операциялық) модель, мұнда ақыл-ой қызметін басқару алдын-ала анықталған қасиеттері бар білім мен дағдылардың пайда болуына кепілдік беретін белгілі бір бағдарлау түрі негізінде жүзеге асырылады;

«Дамытушы» модель оқу материалын арнайы ұйымдастыру және онда абрактіден нақтыға көтерілу бағытында қозғалыс есебінен теориялық ойлауды дамытуға бағытталған [4].

«Белсендіретін» модель баланың танымдық қызығушылықтары мен шығармашылық қабілеттерін дамытуды анықтайтын шешілетін психикалық міндеттердің проблемалық деңгейін жоғарылату арқылы танымдық белсенділікті бірінші орынға қояды;

Жеке тұлғаның өзін - өзі тануының стихиясына бағытталған «еркін» модель, оның дамуы баланың табиғи дамуын сүйемелдеу ретінде ішкі оку резервтерінің имманентті өсуі ретінде түсініледі;

Баланың жеке әлеуметтік - мәдени танымдық тәжірибесін арттыруды қамтамасыз ететін «байыту» моделі.

Білім беруді ізгілендіру үрдісі еркіндік категориясын шығармашылық шарттары, адамның маңызды күштерін мореализациялау ретінде қазіргі заманғы түсінуді байытады. Бұл үрдістің көрсеткіштері:

- балаға құндылық қатынасы, педагогтың қадір - қасиеті мен өз бетінше;

• педагогикалық мақсаттарға қол жеткізу құралдарын шығармашылық түсіну;

- еркіндік - реттеу қағидатының арақатынасы аспектісінде педагогикалық

процесті ұйымдастыру.

Әлемдік білім беру кеңістігіндегі орыс білімінің тенденциялары - бұл жаһандық және жеке жоспардың құндылықтарының азаматтылығы мен қалыптасуы - ғылыми ізденіс пен білім беруді дамыту стратегиясын анықтайтын өмір, денсаулық.

Е.М. Николаева, М.Д. Щелкунов, жоғары білімнің жаһандық кеңістігін дамытудың жалпы тенденцияларын түсіне отырып, оны субъективті, іс - қимыл және қоршаған орта компоненттерінің жиынтығында көрінетін ерекше әлеуметтік - мәдени университет ретінде түсіндіреді. Қарастырылған трендтер мен ерекшеліктер жоғары білім беру саласындағы парадигматикалық өзгерістерді, оның мақсаттарына, мазмұнына, ұйымдастырушылық 
формаларына әсер етеді. Қазіргі заманғы әлеуметтік - экономикалық шындықтар контексінде жоғары білімнің жаһандық кеңістігіне біріктірілген және білім трансфертіне қатысатын бизнеспен және билікпен тиімді ынтымақтасатын кәсіпкерлік құрылымға айналатын университеттің орны мен рөлі түбегейлі өзгереді [5].

Дәстүрлі мақсаттар, жоғары білімнің мазмұны, оның субъектілерінің қызметіне сәйкес қазіргі уақытта прагматизм идеологиясының әсерінен көбірек өзгеруде. Бұл оқытушыға университет түлегіне қандай білім қажет екенін болжау қиын, кейде мүмкін емес, өйткені оның өмірлік белсенділігі өсіп келе жатқан белгісіздікпен белгіленген ортада дамиды. Прагматизм философиясының негізін қалаушы Ч. Пирстің ойынша белгілі бір уақытта өзгермелі әлеуметтік мәдени шындықтың нақты жағдайлары мен қажеттіліктеріне бейімделген тиімді әрекет ету үшін адамға салыстырмалы білімге ие болу жеткілікті. Сондықтан жоғары білім берудің негізгі нәтижелерінің бірі университет түлегінің қиын, белгісіз жағдайларда өзін - өзі адекватты іс - әрекетке қабілеттілігі, бұл жағдайларды қауіп ретінде емес, даму векторлары бар әлеуетті «өсу нүктелерінің» дискурсында қабылдау мүмкіндігі болуы керек. Есте сақтау процесінен оқыту тәжірибе жағдайларын жобалау, рефлексия және шешім табу процесіне айналады. Осындай прагматикалық бағдарлаудың көрінісі студенттерді даярлауда білімдік («білім беру ретінде білім») тәсілден құзыреттілікке («білім беру ретінде әрекет ете білу») көшу, сондай - ақ бітірушілердің құзыреттерін қалыптастырудың негізгі шарты ретінде жобалық әдісті дамыту болып табылады.

В.Э. Попова жоғары білім беру жүйесін жаһандық және ұлттық деңгейлерде басқарудың қазіргі тенденцияларын қарастыра отырып, жоғары білімге қатысты әлемдік білім беру саясатындағы негізгі басым тәсілдерді сипаттайды. Бірінші тәсілге сәйкес стратегиялық дамуды жоспарлау орталықтарының рөлі жоғары кәсіптік білім беру ұйымдарына түседі. Екінші тәсіл жоғары кәсіптік білім беру мекемелері ғылыми - өндірістік және білім беру кешендеріне айналатын университеттік білім беруді ұйымдастырудың «инновациялық - кәсіпкерлік» моделін енгізуді білдіреді. Үшінші тәсіл жоғары білімнің классикалық моделін адам өмір бойы алатын тұрақты білім беру жүйесіне айналдыруды білдіреді. Бұл көптеген оқу орталықтарының, мамандардың біліктілігін арттыру және жаңа мамандықтар бойынша қайта даярлау институттарының дамуын білдіреді.

Қазіргі уақытта «knowledge economy» («таным экономикасы») идеяларын ілгерілетудің жаһандық процесі жүріп жатыр. Елдің әлеуметтік - экономикалық жүйесін сапалы түрде өзгерту және Ұлттың тұрақты әлеуметтік - экономикалық дамуын қамтамасыз ету үшін негіздердің болуы қажет, яғни «білім экономикасы» неден құрылатыны және оның мәні не болып табылатын білу стратегиялық маңызды болып табылады. Өзгерістерді жүзеге асыру шындығының маңызды негізгі белгілерінің бірі - бұл ұлттық білім беру жүйесінің жағдайы.

\section{Пайдаланылған әдебиеттер тізімі:}

1. Лукичев Г.А. Транснациональное образование. Вестник РУДН. 
Серия: Юридические науки. Москва, 2002.

2. Корепанова И.А. Общение и деятельность -два основания для проектирования интегративных (инклюзивных) пространств. Психологическая наука и образование. 2011.

3. Котова С.А. От социальной полезности к культуре достоинства. Аккредитация в образовании. 2011.

4. Лопатина В.И. Широкие аспекты инклюзивного образования. Воспитание и обучение детей с нарушениями развития. 2009.

5. Лопатина Н.В. Инклюзивное образование: прошлое, настоящее, будущее. Alma mater (Вестник высшей школы). 2014. 


\title{
ДИСТАНЦЙНА ОСВІТА НАУКОВО- ПЕДАГОГІЧНИХ ПРАЦІВНИКІВ ЗАБЕЗПЕЧУС ІННОВАЦІЙНІ НОВОВВЕДЕННЯ В СИСТЕМІ ОСВІТИ
}

\author{
Шепітько Володимир Іванович \\ Завідувач кафедри гістології, цитології та ембріології, \\ доктор медичних наук, професор \\ Борута Наталія Володимирівна \\ Доцент кафедри гістології, цитології та ембріології, \\ кандидат біологічних наук \\ Стецук Євгеній Валерійович \\ Доцент кафедри гістології, цитології та ембріології, \\ кандидат медичних наук \\ Української медичної стоматологічної академії
}

Розвиток інформаційних технологій в освітньо-медичному середовищі $є$ суттєвою складовою процесу інформатизації державної галузі охорони здоров'я. Основним змістом державної політики інформатизації України $є$ необхідні заходи, стратегія і тактика, які спрямовані на прискорення входження нашої країни в інформаційний простір міжнародного співробітництва з метою підняття на сучасний рівень медичної освіти, науки $[1,4]$.

Сучасний рівень дистанційної освіти має принципові відмінності в порівнянні з усіма іншими системами освіти завдяки поєднанню інформаційних і комунікаційних технологій. Поєднання цих технологій дозволяє розширити середовище застосування комп'ютера, забезпечує інтерактивну взаємодію 3 комп'ютером, створює принципово нову систему освіти, коли слухач може, знаходячись в будь-якому місці і в будь-який час і підключитись до системи навчання $[2,6]$.

Дистанційна освіта, як відомо, має найрізноманітніші моделі, однією 3 переваг дистанційного навчання $\epsilon$ те, що воно дозволяє значно розширити кількість людей, які бажають одержати знання, забезпечує істотні інноваційні нововведення в системі освіти. Вона:

- по-перше, значно розширює контингент слухачів;

- по-друге, забезпечує навчання незалежно від місця знаходження слухача, у будь-який зручний для нього час;

-по-третє, забезпечує інтерактивну взаємодію слухача не тільки 3 комп'ютером, а з усіма партнерами по спільній діяльності, як з педагогом, так і 3 іншими слухачами, що перебувають у біль-якій точці земної кулі і входять у віртуальну спільноту; 
- по-четверте, надає доступ до віддалених інформаційних ресурсів, включаючи бази знань, електронні бібліотеки, вебінари та он-лайн майстеркласи, експертні й навчальні системи $[1,2,5]$.

Застосування інформаційної мережі Інтернет $\epsilon$ унікальним способом отримання різноманітної інформації, участі у дистанційному навчанні (відеолекції, семінари, наукові конференції і дискусії, обмін організаційнометодичною та науковою інформацією). Крім того, всесвітня мережа виступає також і як джерело інформаційних ресурсів, різноманітних баз знань, електронних бібліотек. Слухачі під час дистанційного навчання, мають можливість користуватись Інтернетом, як глобальною інформаційною системою, що забезпечує прямий доступ до світової та вітчизняної літератури [1, $6]$.

Метою дистанційної освіти науково-педагогічних працівників є оновлення їх теоретичних і практичних знань у зв'язку з підвищенням вимог до рівня кваліфікації та необхідності оволодіння сучасними методами вирішення професійних завдань не відриваючись від місця роботи [4, 5]. Основним завданням дистанційної освіти педагогічних працівників є:

- оновлення та розширення знань, формування нових професійних компетенцій і компетентностей;

- засвоєння інноваційних технологій, форм, методів та засобів навчання;

- набуття досвіду формування змісту навчання, з урахуванням його цільового спрямування, посадових обов'язків педагогічних працівників, попередньо здобутої ними освіти, досвіду практичної роботи та професійної діяльності, інтересів і потреб особистостей;

- вивчення педагогічного досвіду, ознайомлення 3 досягненнями науки, техніки та перспектив їх розвитку;

- розроблення конкретних пропозицій щодо удосконалення навчальновиховного процесу, впровадження в практику навчання кращих досягнень науки, техніки;

- застосування інноваційних технологій реалізації змісту навчання, що передбачає його диференціацію, індивідуалізацію, запровадження дистанційних, інформаційно-комунікативних технологій навчання.

В період пандемії науково-педагогічні працівники дистанційно підвищують кваліфікацію та проходять стажування у вищих навчальних закладах, наукових, навчально-наукових та інших установах, а також на підприємствах, в організаціях, органах державної влади, органах місцевого самоврядування як в Україні, так і за їі межами $[5,6]$.

На науково-педагогічного працівника, згідно із Законом України «Про вищу освіту», покладаються складні й відповідальні обов'язки:

- постійно підвищувати професійний рівень, педагогічну майстерність i наукову кваліфікацію;

- забезпечувати високий науково-теоретичний i методичний рівень викладання дисциплін у всьому обсязі освітньої програми відповідної спеціальності; 
- дотримуватись норм педагогічної етики, моралі, поважати гідність осіб, які навчаються умедичних навчальних закладах, прищеплювати їм любов до України. Виховувати їх у дусі українського патріотизму й поваги до Конституції України;

- дотримуватись законів України, статуту та правил внутрішнього розпорядку вищого навчального закладу [4].

Актуальним завданням вищої педагогічної освіти поряд із професійною підготовкою фахівців різних спеціальностей $є$ підготовка й перепідготовка висококваліфікованих викладачів, підвищення рівня їх педагогічного професіоналізму [3, 4].

Таким чином, впровадження сучасних інноваційних методів дистанційного навчання в системі вищої освіти для науково-педагогічних працівників, в порівнянні $з$ використанням звичайних технологій, дають змогу підвищити рівень засвоєння їм нових знань, зробити процес навчання безперервним та ефективним.

\section{Список літератури}

1. Актуальні питання дистанційної освіти та телемедицини 2018: матеріали Всеукраїнської науково-методичної відеоконференції 3 міжнародною участю (25-26 квітня 2018 року, м. Запоріжжя). - Запоріжжя, 2018. - 171 с.

2. Дистанційне навчання як сучасна освітня технологія. Електронний ресурс]: матеріали міжвузівського вебінару (м. Вінниця, 31 березня 2017 р.) / відп. ред. Л.Б.Ліщинська. - Вінниця: ВТЕІ КНТЕУ, 2017. - 102 с.

3. Шепітько В.І. Дистанційна форма підвищення кваліфікації викладачів, як одна із форм підготовки висококваліфікованих науково-педагогічних працівників освіти / В.I. Шепітько, Н.В. Борута, С.В. Стецук [та ін.] // The V th International scientific and practical conference «Study of modern problems of civilization». - Oslo, Norway 2020. - C. 354-356.

4. Шепітько B.I. Професіоналізм викладачів у медичних вузах як основна складова їх педагогічної майстерності / В.І. Шепітько, І.М. Донець, Н.В. Борута, [та ін.] // I Міжнародна науково-практична конференція «Achievements and prospects of modern scientific research». - Buenos Aires, Argentina, 2020. - C. 377383.

5. Шепітько В.І. Підвищення кваліфікації викладачів, як один із методів їх професійного зростання / В.І. Шепітько, Н.В. Борута, А.С. Григорено [та ін.] // II Міжнародна науково-практична конференція «The world of science and innovation». - Лондон, Великобританія, 2020. - С. 579-583.

6. Шепітько В.І. Підвищення професіоналізму викладачів у вищих медичних закладах України за сучасних умов / В.І. Шепітько, Н.В. Борута, Є.В. Стецук [та ін.] // XIII Міжнародна науково-практична інтернет-конференція «Сучасні виклики i актуальні проблеми науки, освіти та виробництва: міжгалузеві диспути» - Київ, 2021. - С.249-253. 


\title{
ПІДГОТОВКА ЛІКАРІВ-ІНТЕРНІВ В УМОВАХ РЕФОРМУВАННЯ СИСТЕМИ ОХОРОНИ ЗДОРОВ'Я УКРАЇНИ
}

\author{
Шумило Мирослава Юріївна \\ Старший викладач, Кафедра латинської та іноземних мов \\ Львівський національний медичний університет імені Данила Галицького \\ Аспірант, Кафедра педагогіки та інноваційних технологій \\ Національний університет «Львівська Політехніка»
}

Реформа у галузі охорони здоров'я є вкрай важливою для забезпечення якісних послуг населенню, оскільки життя та здоров'я кожного громадянина $\epsilon$ пріоритетною цінністю. Перш за все, реформа системи охорони здоров'я базується на підготовці медичних фахівців з високим рівнем компетентностей та професіоналізму, побудови якісної структури медичної освіти, вивчення прогресивного досвіду інших країн та можливості застосовувати ідеї в українських вишах.

Пошук стандартів вищої медичної освіти $є$ оптимальною стратегією досягнення концептуально нового рівня якості підготовки майбутніх фахівців, основою якого $\epsilon$ підготовка медичних працівників відповідно до загальноприйнятих міжнародних норм викладання з урахуванням особливостей та інтересів національної системи охорони здоров'я $[1,2]$.

Інтернатура $\epsilon$ важливою компонентою підготовки спеціалістів в галузі охорони здоров'я. ÏÏ основною метою є підвищення та вдосконалення рівня практичної підготовки майбутніх фахівців, випускників медичних та фармацевтичних закладів освіти III-IV рівнів акредитації, а також професійної підготовки до самостійної лікарської чи провізорської діяльності.

Міністерство охорони здоров'я України розробило проект акта на виконання Стратегії розвитку медичної освіти, схваленої розпорядженням Кабінету Міністрів України 27 лютого 2019 року та пункту 310 Плану пріоритетних дій Уряду на 2019 рік, затвердженого розпорядженням Кабінету Міністрів України від 18 грудня 2018 року №1106-р.

Прийняття проекту наказу дозволить зменшити бюрократичне навантаження на випускників закладів вищої освіти, що здійснюють підготовку фахівців галузі 22 «Охорона здоров'я» та надасть їм можливість зараховуватися в інтернатуру шляхом електронного розподілу відповідно до рейтингового показника та пріоритетних вакансій, визначених випускником.

Проект наказу вносить зміни до процедур зарахування, проходження та закінчення інтернатури випускниками закладів вищої освіти, що здійснюють підготовку фахівців галузі 22 «Охорона здоров'я». Основні положення наказу передбачають: створюються умови для справедливого розподілу випускників закладів вищої освіти для проходження інтернатури - електронна процедура розподілу; МОЗ перестає виконувати невластиві функції - погодження для переведення/звільнення більше не надаватиметься Міністерством. Такі випадки 
урегульовуватимуться закладами вищої освіти та відповідною базою стажування інтерна; закладено підгрунтя для фінансового забезпечення інтернатури визначено складники витрат на програму підготовки в інтернатурі; затверджуються вимоги до баз стажування для кожної окремої спеціальності; затверджується новий перелік спеціальностей, який скорочено до 13 основних спеціальностей; визначено перелік компетентностей, які повинен набути лікарінтерн за період проходження програми інтернатури; затверджується перелік спеціальностей та строки підготовки в інтернатурі; затверджується форма типового договору про проходження інтернатури на базі стажування [3].

Отже, рейтинговий розподіл буде проводитися на основі отриманого випускником конкурсного балу. Конкурсний бал випускників медичних освітніх закладів буде формуватися закладом вищої освіти, де здійснюється підготовка здобувачів освіти галузі знань «22 Охорона здоров'я» на основі:

- середнього балу, отриманого за весь період навчання;

- результатів єдиного державного кваліфікаційного іспиту для випускників за спеціальностями «221 Стоматологія», «226 Фармація, промислова фармація» у 2021 p. а 32022 p. - для усіх здобувачів ступеня вищої освіти магістр за спеціальностями галузі знань «22 Охорона здоров'я»;

- результатів отриманих у результаті складання ліцензійного інтегрованого іспиту Крок-2 для випускників, які закінчили навчання за спеціальностями «Лікувальна справа», «Педіатрія», «Стоматологія», «Медико-профілактична справа» галузі знань 1201 «Медицина» в 2021 р.;

- результатів складання фахових іспитів залежно від обраної спеціальності, які є визначальними.

На етапі завершення інтернатури, лікарі-інтерни складають ліцензійний іспит «Крок 3», що дає змогу оцінити відповідність рівня професійної компетентності фахівців з вищою освітою. Відповідно до наказу МОЗ України від 05.10.2016 №1043, величина критерію «склав/не склав» визначається на рівні 70,5\% правильних відповідей. Для визначення знань та практичних навичок 3 присвоєнням звання «лікар-спеціаліст» («провізор-спеціаліст»), до атестації допускаються інтерни, які повністю виконали навчальний план та програму підготовки в інтернатурі, а також склали екзамен ліцензійного інтегрованого іспиту Крок-3 успішно.

Підготовка лікарів (провізорів)-інтернів проводиться відповідно до індивідуальних навчальних планів, що розроблені на основі програм підготовки в інтернатурі, та навчальних планів, затверджених Вченою радою закладу вищої та/або післядипломної освіти. Під час навчання в інтернатурі лікарі (провізори)інтерни повинні набути відповідних компетенцій, знань та навичок, які передбачені програмою підготовки в інтернатурі та індивідуальним навчальним планом.

Основним завданням інтернатури є вдосконалення рівня знань та вмінь лікарів (провізорів)-інтернів, їх професійної підготовки до самостійної діяльності за фахом.

Удосконалення медичної освіти $\epsilon$ надзвичайно важливим елементом реформи медицини, що має враховувати потребу у державі в конкретних 
спеціалістах і забезпечувати доступ пацієнтів до якісної медичної допомоги. Якість медичних послуг для пацієнтів значною мірою залежить від якості підготовки лікарів, фармацевтів та стоматологів. Лише висококваліфіковані лікарі, фармацевти, стоматологи, медичні психологи можуть забезпечувати якісні медичні послуги для пацієнтів.

\section{Список літератури}

1. Наказ МОЗ України та АМН України від 12.09.2008 р. № 522/51 “Про затвердження Концепції розвитку вищої медичної освіти в Україні”. Режим доступу: http:// mozdocs.kiev.ua/view.php?id=12141.

2. Морозова О. М. Пошук стандартів вищої медичної освіти для вдосконалення системи охорони здоров'я / О. М. Морозова, Л. В. Батюк, В. Г. Кнігавко // Актуальні питання якості медичної освіти : матеріали XIII Всеукр. наук.-практ. конф. 3 міжнар. участю (з дистанційним під'єднанням ВМ(Ф)НЗ України за допомогою відеоконференц-зв'язку) (Тернопіль, 12-13 трав. 2016 р.). Тернопіль, 2016. Т. 1. С. 109-110.

3. Проект наказу МО3 України «Про затвердження Положення про інтернатуру». Режим доступу: https://moz.gov.ua/article/public-discussionsarchive/proekt-nakazu-moz-ukraini-pro-zatverdzhennja-polozhennja-prointernaturu\#2. 


\title{
МУЗИЧНА ДРАМАТУРГІЯ ЯК ЧИННИК ДИНАМІЧНОГО РОЗВИТКУ МУЗИЧНОГО ТВОРУ
}

\author{
Ярошенко Олена Миколаївна \\ старший викладач кафедри музикознавства, \\ інструментальної та хореографічної підготовки \\ Криворізький державний педагогічний університет
}

Призначенням музичної драматургії у якості важливого чинника динамічного розвитку музичного твору є виявлення та роз'яснення ієрархічної структури елементів музичної форми в процесі їі втілення у реальне звучання, розкриття потенційних можливостей гармонічної мови і формотворення, що закладені у нотному тексті. Більшість важливих категорій музичної форми зазвичай не знаходить у авторському нотному тексті безпосереднього відображення. У ньому прямо не позначені мотиви і речення, кульмінації та спади, приховані поліфонічні голоси, жанрові і стилістичні ознаки. Проте в музичному тексті чітко прописані звукова ладова ієрархія, ритмічні співвідношення окремих звуків, порядок їх одночасності та послідовності, ритм і метр, що в цілому складає елементарну фіксацію звукової системи музичного твору.

Поняття «драматургія» та «музична драматургія» дає певний алгоритм дій, згідно з яким, як визначає кандидат мистецтвознавства Т. Чернова, є можливість «вивчати взаємини образів у процесі становлення цілого, уявити їх у вигляді системи, а також вказати на закони, якими це становлення керувалося» [1].

Слово «драма» має грецьке походження i означає дію. Музична драматургія розглядається як система засобів музичної виразності та прийомів втілення драматичної дії у сценічному жанрі (опері, балеті, опереті). В основі лежать загальні закони драми - центральний конфлікт i етапи розвитку драматичного задуму.

«Драматургія — це цілісний, завершений, відзначений напруженістю й інтенсивністю процес розвитку та взаємодії власне музичних образів у масштабі всього твору або його великої, відносно самостійної частини, рушійною силою якого є конфлікт»,- відзначає Т. Чернова. У цьому визначенні «драматургія» була розглянута дослідником як образна структура музичного твору [1, с. 8]. У свою чергу, С. Назайкінський розглянув поняття «музична драматургія» як набір засобів, принципів, законів, якими вибудовується музичне ціле за прикладом драми [2, с. 6-7].

Цікаву концепцію музичної драматургії та їі класифікацію запропонував В. Бобровський. Науковець в функціональних основах музичної композиції виділяє типи основних функцій у дії: викладення (логічно-композиційна функція), розвитку (експресивно-драматургічна), завершення, які відповідають загальній спрямованості драматургічного розвитку. Тобто, музичну композицію апріорі можна вважати одним із чинників музичної драматургії, враховуючи багатоваріантність іiі поняття в музиці. В. Бобровський розглядає музичну 
драматургію як план та лінію розвитку «суттєвих для реалізації художньої ідеї моментів музичного часу» [3, с. 45], що створюються за допомогою або одного із чотирьох кількісних принципів, або різних форм їх поєднання. За допомогою одного із трьох якісних категорій - не контрастності, контрастності, конфліктності (можливі також їх сполучення та переключення) утворюються відповідні типи драматургії.

В. Бобровський виокремлює чотири таких типи експресивнодраматургічної функції, яка, за його поглядами, утворює драматургію твору: одно елементна (моно драматургія), у якій розвивається лише один «момент часу» (момент часу розглядає за формулою Б.Асаф'єва i:m:t, відповідно, початок-розвиток-завершення музичної дії); двоелементна (парна), яка функціонує як зіставлення двох різних, доведених до контрасту й конфлікту, «моментів часу»; триелементна (тріадна), що працює за принципом «тезаантитеза-синтез»; багатоелементна (множинна), функціонально-філософська основа якої $є$ «зміна типів виразності, психологічних станів, втілених у вигляді відмінних одне від одного моментів часу» $[4$, с. 63$]$.

Загалом у різних розуміннях про музичну драматургію, можна виокремити чотири ключові пункти, що складають суть поняття. Перший полягає в тому, що драматургія - це система, яка працює за певними законами й принципами. Другий пункт вказує на те, що в основу музичної драматургії покладені конструктивні засади драми, поняття «конфлікт». У третьому пункті констатуємо динамічний характер системи драматичного розвитку пов'язаний з поняттям образа, психологічних станів тощо. Четвертий полягає у самій природі ладових звукових висотних тяжінь, які утворюють динамічну систему функціональних відношень в музиці, пов'язану із законами гармонічного музичного розвитку, схожого із загальними законами драматургії.

На думку музикознавця А.М'ясоєдова в музиці характер взаємодії функцій знаходиться у прямій залежності від загальної логіки розвитку, яка притаманна всім видам часових мистецтв, до яких відноситься музика (література, театр, кіноіндустрія - мистецтва, які протікають у часі; на відміну від них архітектура, живопис, скульптура - просторові мистецтва). Для часових мистецтв характерні наступні етапи розвитку дії: відносний спокій, зав'язка, розвиток конфлікту, кульмінація, розв'язка. В музиці цим етапам розвитку відповідають: стійкість нестійкість - загострення нестійкості - розв'язання. Така послідовність етапів розвитку властива різним рівням (крупного твору або його частини, періоду, речення тощо) і являє собою своєрідні хвилі розвитку різної тривалості.

В гармонічному розвитку найменша хвиля такого типу відповідає мотиву, фразі, утворюється за умов взаємодії ладо гармонічних функцій, які характерні для різних ладів. Наприклад, в мажорному ладі етапам стійкість - нестійкість загострення нестійкості - розв'язання - відповідає послідовність функцій $\mathrm{T}-\mathrm{S}$ - D - T. Цей «коловоріт» функцій може бути більш розширеним і менш розширеним, більш повним або менш повним [5, с.28].

Т. Чернова виокремлює три масштабно-часові рівні осягнення драматургії твору музикантом. Перший рівень визначається роботою слухових аналізаторів та охоплює ділянку від окремих звуків до фрази; сприйняття спирається на 
виокремлення таких показників, як динаміка, тембр, фактура, регістр. Другий рівень осягнення музичної драматургії пов'язується з осягненням структури твору від мотиву до періоду (простої форми), виявленням тематичних, ладогармонічних характеристик. Третій рівень масштабно-часового осягнення драматургії, на думку музикознавця, базується на уявленнях про твір як об'єктивну цілісність формотворчих, художньо-виразних та конструктивнологічних характеристик [1, с.82].

Зазначені види класифікації музичної драматургії підтверджують думку про те, що науковці часто пов'язують музичну драматургію зі змістом таких мистецьких понять, як тематизм, форма, гармонічний розвиток, музичний стиль і жанр. В дослідженнях музикознавців навіть зустрічаються такі терміни як «образна драматургія», «драматургія наростання», «тематична драматургія» тощо.

На думку Л. Мазеля, Б. Теплова, В. Холопової, тематизм як чинник музичної драматургії виступає основою музичного розвитку, стрижнем становлення форми музичного твору, а також відображає зв'язок музичного твору з дійсністю.

Більшість дослідників вважають, що музична форма $\epsilon$ чинником драматичного розвитку і виступає як конкретне художньо-звукове явище. Її̈ можна розкласти на окремі елементи, аналітично простеживши характер багатосторонніх зв'язків або усвідомлюючи красу форми твору інтуїтивно. За наявності достатнього музичного досвіду та навичок внутрішньо-слухового інтонування це стає можливим для виконавця без прослуховування музики, лише за допомогою перегляду їі матеріальної форми - нотного тексту.

Цілісні уявлення про розвиток образної сфери музичних творів, тобто, «образної драматургії», багато в чому базуються на понятті музичних жанрів. Адже до їх складу входять не тільки коло образів, що обумовлюють ідейнохудожній зміст та відображають ознаки певної історичної епохи, їм притаманні власні засоби виразності та прийоми типізації життєвого змісту в музиці. «Створення виконавського образу неможливе без урахування національних $\mathrm{i}$ жанрових особливостей твору, історичної своєрідності епохи, на тлі якої він був створений, а також стилю композитора», - підкреслює О. Алексєєв [6, с. 95].

Зазначимо, що образ, яким би невловимим він не був, виникає на базі певної структури, створеної засобами конкретного виду мистецтва (у нашому випадку музичного). Інакше кажучи, образ, якщо його розглянути iз формального погляду, є результатом взаємодії засобів виразності [7].

Призначення музичної драматургії, розуміння іiі законів в кінцевому результаті полягає в бездоганному виконанні музичного твору. Практикою музичного виконавства доведено, що без осмислення логіки розвитку музичного твору, його структури, тобто, драматургічних принципів розвитку одного образу або драматургічного укладання творів циклічної побудови, неможливо досягнути художньо-виконавської цілісності. Сформованість уявлень про драматургію розвитку музично-образної сфери сприяе більш чіткому усвідомленню логічних зв'язків музичної тканини (фактури), допомагає музиканту цілісно і в динаміці сприйняти авторський задум. 
Отже, драматургія музичного твору виконує роль суттєвого фактора музичного процесу, який генерує і забезпечує динаміку смислу, зберігаючи художньо-логічні норми музичного висловлювання, жанрові, стильові, фактурно-стилістичні та інструментально-специфічні якості музики. Осягнення законів музичної драматургії, формотворення та розвитку, розуміння виразових можливостей елементів музичної мови, створення чітких уявлень про взаємодію художніх засобів, здатність розпізнавати характерні для даного автора прояви його стилю - усе це збагачує та активізує сприйняття і виконання музики, поглиблює іiі тлумачення.

Розуміння законів музичної драматургії як образної і динамічної системи музичного твору не тільки відкриває широкі можливості до розробки його виконавської концепції, а й виступає запорукою повноцінного творчого процесу роботи над художнім змістом, глибокого пізнання психологічної сутності кожного елементу музичної мови.

\section{СПИСОК ЛІТЕРАТУРИ}

1. Чернова Т. Драматургия в инструментальной музыке. Москва, 1984. 144 с.

2. Назайкинский Е. Логика музыкальной композиции. Москва : Музыка, 1982. $319 \mathrm{c.}$

3. Бобровский В. К вопросу о драматургии музыкальной формы. Москва : Музыка, 1971. 305 с.

4. Бобровский В. Функциональные основы музыкальной формы. Москва : Музыка, 1977. 322 с.

5. Мясоедов А. Учебник гармонии : учебник для муз. училищ. Москва : Музыка, 1980. 319 с., нот.

6. Алексеев А. Методика обучения игре на фортепиано. Москва : Музыка, 1978. $288 \mathrm{c}$.

7. Альзубейди А. Сутність поняття «образно-драматургічні уявлення музиканта» в контексті інструментально-виконавської діяльності. Актуальні питання мистецької педагогіки. 2017. вип. 6. Київ. URL: http://apmp.kgpa.km.ua (дата звернення 25.02.2021). 


\section{ПРАВОВЕ РЕГУЛЮВАННЯ ОСВІТНЬОЇ ДІЯЛЬНОСТІ У ФАРМАЦЇ̈}

Козирсва Олена Вадимівна, д.е.н., професор Національний фармацевтичний університет

Коляда Тетяна Анатоліївна к.ю.Н., доцент Національний фармацевтичний університет

\section{Сагайдак-Нікітюк Ріта Василівна} д.фарм.н., професор Національний фармацевтичний університет

Відповідно до частини 1 статті 53 Конституції України закріплено право кожного на освіту без обмежень за ознаками раси, кольору шкіри, політичних, релігійних та інших переконань, статі, етнічного та соціального походження, майнового стану, місця проживання, за мовними або іншими ознаками. Право на освіту розглядається як комплекс специфічних прав, що охоплює: право на обов'язкову й безоплатну початкову освіту для всіх; право на відкритість i доступність середньої освіти; право на однакову доступність для всіх на конкурсній основі до вищої освіти [1].

Основний Закон передбачає відповідальність держави за забезпечення доступності і безоплатності вищої освіти. Доступність освіти як конституційна гарантія реалізації права на освіту на принципах рівності означає, що нікому не може бути відмовлено в праві на освіту. Держава має створити можливості для реалізації цього права. Натомість безоплатність освіти як конституційна гарантія реалізації права на освіту означає можливість набуття в державних та комунальних закладах без внесення плати в державних i комунальних навчальних закладах на конкурсній основі в межах обсягу підготовки фахівців для загальних потреб (державного замовлення). Закладам вищої освіти державної та комунальної форм власності дозволено здійснювати підготовку фахівців з вищою освітою як за державним замовленням, так й за рахунок інших джерел фінансування, за умови, що така діяльність не заборонена законом, відповідає створеній в Україні системі безперервної освіти, забезпечена належною кількістю кваліфікованих фахівців, матеріально-технічною i виробничою базою.

Законом України «Про вищу освіту» від 1 липня 2014 року № 1556-VII встановлено основні правові, організаційні, фінансові засади функціонування системи вищої освіти. Цим законом передбачено створення умов для посилення співпраці державних органів і бізнесу з закладами вищої освіти на принципах автономії закладів вищої освіти, поєднання освіти з наукою та виробництвом 3 метою підготовки конкурентоспроможного людського капіталу для високотехнологічного та інноваційного розвитку країни, самореалізації особистості, забезпечення потреб суспільства, ринку. праці та держави у кваліфікованих фахівцях. У цьому законі легально закріплено основн1 правові дефініції в галузі освіти на кшталт «вища освіта», «заклад вищої освіти», «освітня діяльність» тощо.

Так, вища освіта визначена як сукупність систематизованих знань, умінь i практичних навичок, способів мислення, професійних, світоглядних i громадянських якостей, морально-етичних цінностей, інших компетентностей, здобутих у закладі вищої освіти (науковій установі) у відповідній галузі знань за 
певною кваліфікацією на рівнях вищої освіти, що за складністю є вищими, ніж рівень повної загальної середньої освіти.

Закладом вищої освіти є окремий вид установи, яка є юридичною особою приватного або публічного права, діє згідно з виданою ліцензією на провадження освітньої діяльності на певних рівнях вищої освіти, проводить наукову, науковотехнічну, інноваційну та/або методичну діяльність, забезпечує організацію освітнього процесу і здобуття особами вищої освіти, післядипломної освіти 3 урахуванням їхніх покликань, інтересів і здібностей.

Натомість освітня діяльність $є$ діяльністю закладів вищої освіти, спрямованою на організацію, забезпечення та реалізацію освітнього процесу [2].

Природне невід'ємне і непорушне право кожної людини на охорону здоров'я закріплено Законом України «Основи законодавства України про охорону здоров’я» від 19 листопада 1992 року № 2801-XII. Законодавець визнав відповідальність суспільства i держави перед сучасним i майбутніми поколіннями за рівень здоров'я і збереження генофонду народу України, за забезпечення пріоритетності охорони здоров'я в діяльності держави, поліпшення умов праці, навчання, побут і відпочинок населення, розв'язання екологічних проблем, вдосконалення медичної допомоги і ствердження здорового способу життя.

Цим законом визначено правові, організаційні, економічні та соціальні засади охорони здоров'я в Україні, врегульовано суспільні відносини в цій сфері з метою забезпечення гармонійного розвитку фізичних і духовних сил, високої працездатності і довголітнього активного життя громадян, усунення факторів, що шкідливо впливають на їх здоров'я, попередження i зниження захворюваності, інвалідності та смертності, поліпшення спадковості, а також дано визначення стрижневих дефініцій «охорона здоров'я» та «заклад охорони здоров'я».

Закладом охорони здоров’я є юридична особа будь-якої форми власності та організаційно-правової форми або ії відокремлений підрозділ, що забезпечує медичне обслуговування населення на основі відповідної ліцензіі та професійної діяльності медичних (фармацевтичних) працівників.

Охорона здоров'я тлумачиться як система заходів, що здійснюються органами державної влади та органами місцевого самоврядування, їх посадовими особами, закладами охорони здоров'я, фізичними особами підприємцями, які зареєстровані в установленому законом порядку та одержали ліцензію на право провадження господарської діяльності з медичної практики, медичними та фармацевтичними працівниками, громадськими об'єднаннями $і$ громадянами з метою збереження та відновлення фізіологічних і психологічних функцій, оптимальної працездатності та соціальної активності людини при максимальній біологічно можливій індивідуальній тривалості їі життя [3].

Розробка та впровадження стандартів Належної аптечної практики (НАП) у діяльність аптечних закладів є логічним продовженням стратегіі імплементації системи належних практик, що гарантує забезпечення якості лікарських засобів на всіх етапах їх обігу від виробництва до реалізації кінцевому споживачеві. Одна 3 ключових вимог Належної аптечноі практики до фахівців фармації полягає у підтримці та постійному удосконаленні рівня професійної діяльності.

Документом стратегічного рівня $є$ Концепція розвитку фармацевтичного сектору галузі охорони здоров’я України на 2011-2022 рр., затверджена наказом Міністерства охорони здоров’я України від 13.09.2010 року № 769. Примітно, що Концепція розроблена відповідно до рекомендацій Всесвітньої організації охорони здоров'я та передбачає визначення основних засад встановлення через нормативно-правові та нормативно-технічні документи положень, правил, нормм поведінки та вимог, що регулюють обіг лікарських засобів в Україні. Концепцією передбачено розроблення стратегії діяльності фармацевтичного сектору, який має забезпечувати належний рівень якості та ефективності фармакотерапї, сприяти підвищенню здоров'я, збільшенню тривалості і якості життя усього населення України [4].

До основних напрямів і пріоритетів розвитку фармацевтичного сектору вітчизняної галузі охорони здоров'я належить формування менеджменту у фармацевтичному секторі, реформування науки та освіти, адекватної потребам 
галузі та сучасної трансформації суспільства, поліпшення інформаційного забезпечення та створення прозорої системи функціонування фармацевтичного сектору галузі охорони здоров'я. Окремий розділ Концепції присвячено науковій та освітній діяльності. Передбачено, що політика Міністерства охорони здоров’я України у сфері наукової діяльності повинна бути першочергово спрямована на забезпечення лікувального процесу за європейськими стандартами та забезпечення імпортозаміщення.

Примітно, що в контексті реформування фармацевтичного сектору наука розглядається як рушійна сила, що забезпечує всебічне наукове обгрунтування необхідності перебудови галузі, визначає прогнозні тенденції в певних групах лікарських засобів та розробляє науково обгрунтовані заходи щодо їх вдосконалення, а також передбачає досягнення таких пріоритетів: посилення ролі наукових профільних закладів у провадженні пріоритетних фундаментальних і прикладних досліджень; запровадження багатоканального фінансування фармацевтичної науки за рахунок бюджетних та позабюджетних коштів, забезпечення їх раціонального використання для першочергового фінансування конкурентоспроможних наукових розробок фундаментального та прикладного характеру; модернізацію технологічних процесів, освоєння нового обладнання, впровадження нових технологій; створення нових моделей функціонування фармацевтичної галузі, передбачивши посилення та вдосконалення інвестиційної моделі розвитку фармацевтичної галузі, підготувати базу до переходу на інноваційну модель розвитку фармацевтичної галузі (забезпечення активної роботи наукових парків, дослідницьких центрів на базі навчальних закладів, тощо); формування сучасної системи економічного й аналітичного забезпечення наукових розробок, активізування створення інтегрованих науково-освітніх структур у системі МО3 України, сприяння розвитку науково-дослідної інфраструктури, залученню i формуванню венчурного капіталу. Особлива увага приділена організації внутрішньофірмових венчурних підрозділів у науково-дослідних інститутах (центрах) i закладах вищої освіти, які мають опікуватися низкою питань, а саме: комерціалізацією наукових розробок; створенням регіональних фармацевтичних кластерів із залученням наявного наукового, освітнього, виробничого та кадрового потенціалу окремих регіонів, у тому числі на основі приватно-державного партнерства; розробленням і впровадженням системи оцінювання медичних (фармацевтичних) технологій HTA (Health Technology Assesment), що включає нормативно-правове забезпечення процесу оцінки нових та діючих технологій, а також комплекс навчально-освітніх заходів із залученням Державного підприємства «Державний експертний центр MO3 України» як головної організації у сфері розробки медико-технологічних документів зі стандартизації медичної допомоги; включення в навчальні програми переддипломної та післядипломної освіти питань, пов'язаних 3 процесами раціонального використання лікарських засобів, а саме: доказової медицини, формулярної системи, фармаконагляду, оцінки медичних технологій тощо.

Основними цілями освітньої діяльності у сфері фармації є: створення умов для розвитку осіб та творчої їх самореалізації, які обрали професію провізора, виховання покоління людей, здатних ефективно працювати й навчатися протягом життя, оберігати й збільшувати цінності національної фармацевтичної науки, культури та громадянського суспільства, розвивати й зміцнювати суверенну, незалежну, демократичну, соціальну. та правову державу як невід'ємну складову європейської та світової спільноти; відтворення інтелектуального потенціалу держави, формування моральних принципів та норм поведінки осіб; забезпечення фармацевтичної галузі України висококваліфікованими фахівцями, які можуть успішно працювати в умовах перехідної економіки, реального професійного й міжнародного оточення, що постійно змінюється; зростання якісного професійного рівня підготовки спеціалістів 3 орієнтацією на міжнародні освітні стандарти за рахунок першочергового вдосконалення змісту та форм фармацевтичної освіти, що приведе до підвищення якості послуг у фармацевтичній галузі.

Закон України «Про професійний розвиток працівників» від 12 січня 2012 року № 4312-VI визначає правові, організаційні та фінансові засади 
функціонування системи професійного розвитку працівників та закріплює низку важливих категорій («неформальне професійне навчання працівників», «професійне навчання працівників», «формальне професійне навчання працівників»).

Професійне навчання працівників визначено як процес цілеспрямованого формування у працівників спеціальних знань, розвиток необхідних навичок та вм1нь, що дають змогу підвищувати продуктивність праці, максимально якісно виконувати функціональні обов'язки, освоювати нові види професійної діяльності, що включає первинну професійну підготовку, перепідготовку i підвищення кваліфікації працівників відповідно до потреб виробництва. До видів професійного навчання працівників віднесено формальне професійне навчання працівників та неформальне професійне навчання працівників.

Натомість неформальне професійне навчання працівників тлумачиться як «набуття працівниками професійних знань, умінь і навичок, не регламентоване місцем набуття, строком та формою навчання», а формальне професійне навчання працівників розглядається як «набуття працівниками професійних знань, умінь і навичок у закладі освіти або безпосередньо у роботодавця відповідно до вимог державних стандартів освіти, за результатами якого видається документ про освіту встановленого зразка» [5].

2018 року було прийнято Положення про систему, безперервного професійного розвитку фахівців у сфері охорони здоров'я, затверджене постановою Кабінету Міністрів України від 28 березня 2018 року № 302. Цим документом визначено основні організаційні засади безперервного процесу навчання та вдосконалення професійних компетентностей фахівців після здобуття ними вищої освіти у сфері охорони здоров'я та післядипломної освіти в інтернатурі. Це дозволить підтримувати та покращувати стандарти їх професійної діяльності відповідно до потреб сфери охорони здоров'я, та триватиме впродовж усього періоду професіиної діяльності.

У зазначеному Положенні дано визначення низки понять, а саме: бал безперервного професійного розвитку; безперервний професійний розвиток фахівців у сфері охорони здоров'я; інформальна освіта (самоосвіта) у сфері охорони здоров'я; неформальна освіта у сфері охорони здоров'я; особисте освітне портфоліо.

Балом безперервного професійного розвитку $є$ одиниця вимірювання навчального навантаження здобувача освіти.

Безперервний професійний розвиток фахівців у сфері охорони здоров’я визначено як безперервний процес навчання та вдосконалення професійних компетентностей фахівців після здобуття ними вищої освіти у сфері охорони здоров'я та післядипломної освіти в інтернатурі, що дає змогу фахівцю підтримувати або покращувати стандарти професійної діяльності відповідно до потреб сфери охорони здоров'я та триває протягом усього періоду професійної діяльності.

Інформальною освітою (самоосвітою) у у сфері охорони здоров'я $\epsilon$ самоорганізоване здобуття фахівцями у сфері охорони здоров'я професійних компетентностей під час повсякденної діяльності, пов'язаної 3 професійною, громадською або іншою діяльністю.

Неформальна освіта у сфері охорони здоров'я - діяльність 3 підвищення власних знань та вмінь, яка провадиться за освітніми програмами та не передбачає присудження визнаних державою освітніх кваліфікацій за рівнями освіти, але може завершуватися присвоєнням професійних та/або присудженням часткових освітніх кваліфікацій.

Особисте освітнє портфоліо є сукупністю задокументованих відомостей щодо персональних досягнень, проходження періодів підвищення кваліфікації, неформальної та інформальної освіти фахівців у сфері охорони здоров'я у процесі безперервного професійного розвитку.

Усі фахівці в сфері охорони здоров'я після здобуття вищої освіти у зазначеній сфері охорони здоров'я та отримання кваліфікації після закінчення навчання в інтернатурі для подальшої атестації відповідно до законодавства зобов’язані дотримуватися вимог до безперервного професійного розвитку [6]. 
Безперервний професійний розвиток включає участь у процесі формальної, неформальної та інформальної освіти у сфері охорони здоров'я. Навчання на циклах спеціалізації, тематичного удосконалення, курсах інформації та стажування здійснюється на базі закладів вищої освіти, закладів післядипломної освіти, науково-дослідних установ, закладів охорони здоров'я. Відповідно до частини 7 статті 18 Закону України «Про освіту» передбачено, що лікарська резидентура проводиться в університетах, академіях, інститутах, наукових установах, закладах охорони здоров'я, визнаних Міністерством охорони здоров’я України як бази лікарської резидентури [7].

До основних форм безперервного професійного розвитку належать: участь у тематичних школах, семінарах, науково-практичних конференціях, конгресах, симпозіумах, з’їздах, у симуляційних тренінгах, майстер-класах, курсах 3 оволодіння практичними навичками, медичне стажування за межами закладу, де працює фахівець, дистанційне навчання, у тому числі 3 використанням електронних навчальних ресурсів, навчання на циклах тематичного удосконалення в закладах (на факультетах) післядипломної освіти тощо.

Організаторами (провайдерами) заходів безперервного професійного розвитку, за як1 нараховуються бали, можуть бути Міністерство охорони здоров'я 'України, структурні підрозділи з питань охорони здоров'я обласних, міських держадміністрацій, наукові установи та організації, заклади вищої освіти та заклади післядипломної освіти, професійні асоціації та спілки, організації роботодавців, громадські організації, міжнародні організації, їх представництва в Україні, міжнародні професійні асоціації, українські підприємства, інші установи та організації тощо. Вимоги до заходів безперервного професійного розвитку затверджуються Міністерством охорони здоров'я України.

Система післядипломної освіти $є$ невід'ємною складовою концепції безперервної фармацевтичної освіти. Відповідно до наказу Міністерства охорони здоров"я України «Про вдосконалення атестації провізорів та фармацевтів» від 12 грудня 2006 року № 818 з метою подальшого вдосконалення атестації фармацевтичних кадрів було затверджено Положення про порядок проведення атестації провізорів, Номенклатуру провізорських спеціальностей та Положення про проведення атестації фармацевтів [8].

Атестація провізорів проводиться 3. метою підвищення професійної майстерності, відповідальності за ефективність та якість роботи; $\epsilon$ важливою формою морального та матеріального стимулювання, спрямованою на вдосконалення діяльності аптечних закладів (підприємств) усіх форм власності, що займаються фармацевтичною діяльністю. Основним завданням атестації $\epsilon$ визначення рівня професійної підготовки провізорів та підвищення їх кваліфікації. Наразі встановлено такі види атестації:

- атестація на визначення рівня знань та практичних навиків 3 присвоєнням (підтвердженням) фаху, передбаченого чинним освітнім законодавством України;

- атестація на присвоєння кваліфікаційної категорії;

- атестація на підтвердження кваліфікаційної категорії.

Атестація на присвоєння (підтвердження) кваліфікаційних категорій проводиться комісіями, що створюються при Міністерстві охорони здоров'я України (Центральна атестаційна комісія), територіальних органах Державної служби України з лікарських засобів та контролю за наркотиками (атестаційні комісії).

Атестаційні комісії при територіальних органах Державної служби України з лікарських засобів та контролю за наркотиками проводять атестацію провізорів, які працюють в аптечних закладах (підприємствах) усіх форм власності, що займаються фармацевтичною діяльністю на території даного регіону.

Провізори, які працюють в аптечних закладах (підприємствах), підпорядкованих відомствам, що не мають своїх атестаційних комісій, проходять атестацію в атестаційних комісіях системи Міністерства охорони здоров'я України за місцезнаходженням.

Відповідно до Спільної настанови Всесвітньої організації охорони здоров’я (ВОOЗ) та Міжнародної фармацевтичної федераціі (МФФ) «Належна 
аптечна практика: Стандарти якості аптечних послуг» (настанова МФФ/ВООЗ 3 НАП) однією 3 основних ролей провізора $\epsilon$ підтримка і поліпшення фахової поточної та майбутньої діяльності шляхом впровадження стратегії постійного професійного розвитку, що потребує встановлення мінімальних національних стандартів до даного виду діяльності, зокрема:

- провізори (фармацевти) повинні сприймати безперервний професійний розвиток як довічний процес і бути спроможними продемонструвати поліпшення теоретичних знань, практичних навичок i ефективність пройденого етапу навчання;

- провізори (фармацевти) повинні оновлювати свої знання сучасних фармакотерапевтичних підходів до лікування та профілактики основних нозологічних форм, у. т. ч. iз застосуванням дієтичних добавок, гомеопатичних препаратів тощо;

- провізори (фармацевти) повинні оновлювати свої знання і долучатися до впровадження нових технологій і автоматизації аптечної практики;

- провізори (...армацевти) повинні бути поінформованими щодо актуальної інформації з питань застосування лікарських засобів.

Застосування стандартів НАП є важливим аспектом удосконалення якості надання фармацевтичних послуг фахівцями аптечних закладів. Розробка i впровадження у практику стандартів за окремими напрямами діяльності аптечного закладу дозволять адекватно оцінити його роботу та прийняти обгрунтовані управлінські рішення. Ще 1997 року ВОО3 артикулювала концепцію «фармацевт семи зірок», а 2000 році МФФ імплементував иіi до документу про Належну практику фармацевтичної освіти.

Наразі зазначена концепція не втратила актуальності. Аби брати участь у сучасній фармацевтичній практиці, провізори (фармацевти) мають навчатися все життя. Метою навчання є поглиблення професійних знань, умінь та навичок, ознайомлення зі змінами в нормативно-правовому регулюванні фармацевтичної галузі тощо [9].

Резюмуючи, зазначимо, що провізор (фармацевт) повинен усвідомлювати, що безперервна освіта і професійний розвиток $є$ безумовними імперативами якісного виконання посадових обов'язків та кар'єрного зростання.

\section{Список літератури:}

1. Конституція України : офіц. текст. Київ : КМ, 2019.96 с.

2. Про освіту : Закон України від 05.09.2012 р. № 2145-VIII. Дата оновлення : 18.06.2020. URL : https://zakon.rada.gov.ua/laws/show/2145-19\#Tеxt (дата звернення : 12.01.2021).

3. Про вищу освіту : Закон України від 01.07.2014 p. № 1556-VII. Дата оновлення : 02.09.2020. URL : https://zakon.rada.gov.ua/laws/show/1556-18\#Text ( дата звернення : 17.01.2021).

4. Основи законодавства України про охорону здоров’я : Закон України від 19.11 .1992 p. № 2801- XII. Дата оновлення : 31.12.2020. URL https://zakon.rada.gov.ua/laws/show/2801-12\#Tеxt (дата звернення : 20.01.2021).

5. Про професіиний розвиток працівників : Закон Украіни від 12.01.2012 р. № 4312 - VI. Дата оновлення : 05.12.2019. URL https://zakon.rada.gov.ua/laws/show/4312-17\#Text (дата звернення : 19.01.2021).

6. Про затвердження Положення про систему безперервного професійного розвитку фахівців у сфері охорони здоров’я від 28 березня 2018 року № 302 : Постанова Кабінету Міністрів від України. https://zakon.rada.gov.ua/laws/show/302-2018-\%D0\%BF\#Text (дата звернення : 25.01.2019).

7. Про вдосконалення атестації провізорів та фармацевтів : Наказ Міністерства охорони здоров’я України від 12 грудня 2006 року № 818. URL : https://zakon.rada.gov.ua/laws/show/z1366-06\#Text (дата звернення 16.01.2021).

8. Довжук Н.Ш., Довжук В.В., Ліпська О.О. Методичні основи організації викладання спеціальних дисциплін магістерської підготовки провізорів у вищих навчальних закладах України. URL : http://asp.kymu.edu.ua/v/01(6)/9.pdf (дата звернення 03.12.2020) 
9. Громовик Б.П. Горілик А.В. Аналіз дидактичних питань фармацевтичної освіти : методичні рекомендації. Львів. 2012. - 20 с. 


\title{
BLENDED LEARNING AT HIGHER EDUCATIONAL ESTABLISHMENTS: ADVANTAGES AND DISADVANTAGES
}

\author{
Zahorodnia Olha \\ Ph.D., Associate Professor \\ National Academy of Statistics, \\ Accounting and Audit \\ Korobova Iryna \\ Ph.D., Senior Teacher \\ National University of Ukraine on \\ Physical Education and Sport
}

Blended learning is an approach to learning that combines face-to-face and online learning experiences. Nowadays blended learning combines modern learning technologies with traditional learning methods (Picture 1).

Successful blended learning occurs when technology and teaching inform each other: material becomes dynamic when it reaches students of varying learning styles.

Blended learning uses online and offline technologies in tandem, allowing instructors to quickly adopt the latest learning trends and modalities into the curriculum at higher educational establishments.

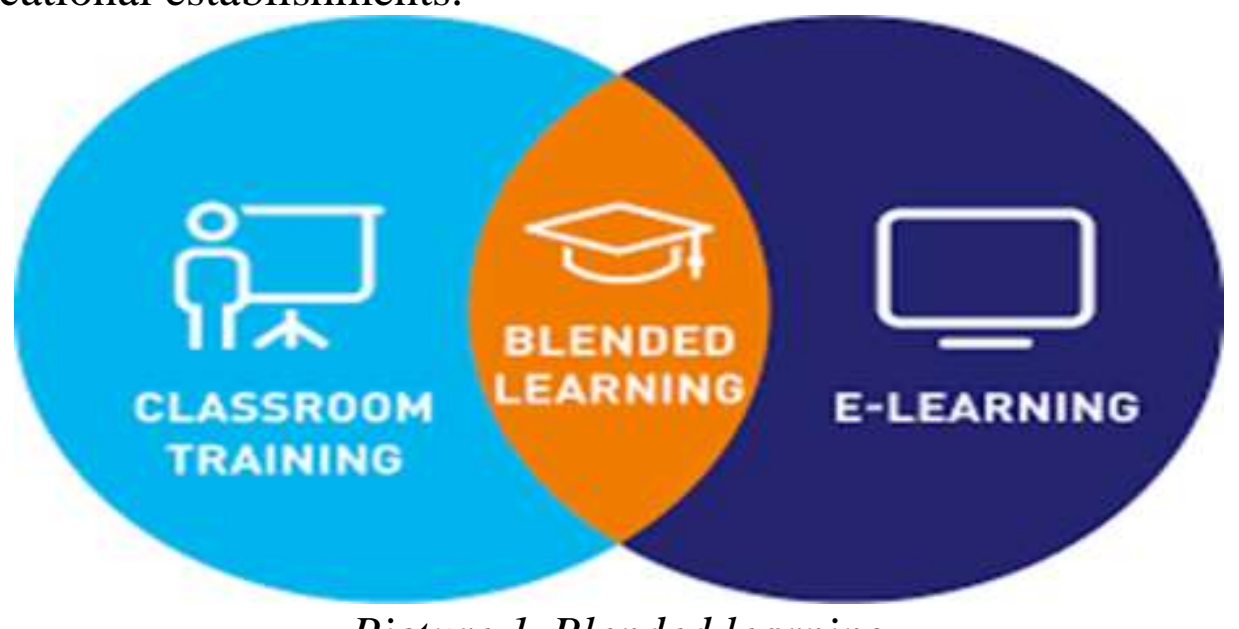

Picture 1. Blended learning

Like any learning method, blended learning comes with unique pros and cons that are important to consider when adopting a blended learning approach. Main benefits:

1. A personalized training experience

The strongest aspect of blended learning is the chance to receive personalized training by every individual, catering to their learning needs. This means that every participant has different learning capabilities and not all of them are always on the same page in terms of grasping the information. They may choose the path through specific 
topic areas as they deem right. Undoubtedly, the face-to-face interaction and various aids to receive timely performance feedback have made blended learning a unique training and development strategy. The overall result of this particular training strategy is to enable every learner to focus on the information and skills they are in need of, without having to attend long unnecessary lectures or going through piles of unrelated information.

\section{Better communication and collaborative learning}

Even though with blended learning strategy, a participant can access the resources in the absence of the instructor, it still improves the communication and interaction amongst the participants and also with the instructors. Such online learning platforms offer a great variety of communication tools such as email, news announcements, instant messaging, online grading tool, online discussion, drop boxes, or more. All of these communication tools offer great flexibility in terms of ensuring timely communication. May it be any concern or feedback/evaluation, all of this is now possible instantly and without any time constraint. Similarly, unlike traditional classroom, blended learning offers a good collaborative environment for participants. This substantially increases collaboration amongst the learners and between the instructor and the learner, which makes blended learning strategy one of the best online training platforms. As the learners use many collaborative tools such as blogs, online discussions, instant messages and others, they are able to collaborate with each other in a better way and in fact, in or out of the training room.

3. Track participants' skill and performance development

If you have incorporated right tools into your blended learning course, you can easily track down the data in terms of participants' eventual performance improvement. This learning strategy makes data tracking a lot more convenient and quick. It helps in eliminating the cookie cutter approach of grading exams. Instead, it offers a better evaluation option of online assessment that comes with a built-in grading rubric with an additional benefit of immediate feedback. This modern learning strategy can easily track the material accessed by a participant. It also shows at what time and for how long they reviewed the material. All of this, especially in a corporate setup, can easily be done digitally and this provides the track record of employees which are then further used to take their promotion and development decisions. In fact, nowadays many organizations use this opportunity to determine activities which are more effective and the ones which need improvisation or modification to fully meet the objectives or performance goals.

\section{Cost-effective training strategy}

Every business strives to make strategies that are both smart and cost-effective and blended learning is just one of these strategies. As you incorporate more and better online options in the blended learning program, it not only saves the traveling cost but also the cost of missed work. That is, as you integrate the events of your training program in an online setup, it not only eliminates the limitations of time and place but also reduces travel cost for both the instructor and the participants. There is no need for any instructor to be present at a location and also there is no need to rent out the training space. Similarly, the same advantage can be availed considering the availability of content on an online platform. The courses can be expanded and updated 
in just a fraction of the time because there's no need to worry about the printing of course material like in the case of the traditional classroom.

\section{24/7 access to training resources.}

Blended learning training removes time and location limitations. Learners no longer have to wait for a scheduled training to address their concerns and questions, as the online training resources are always there to help.

\section{Fun and Engagement}

Blended learning is an interactive experience in every sense of the word. Learners reinforce the offline lessons by practicing online through a variety of different content media, each geared to suit a certain learning style. Learners can choose which type of content they want to interact with, practice what they learn, and communicate with instructors and other learners any time and on any device. The community experience keeps learners engaged and informs teachers about their progress and areas needing more attention.

What are the disadvantages of blended learning?

\section{Temporary increase in the workload (transition phase)}

It's not easy to switch to a new method if you are already accustomed to a traditional approach. It's hard to disagree that there's a significant amount of work involved in the early stage of blended learning where you set everything up. It's not easy to switch to a new method if you are already accustomed to a traditional approach. You might wonder how to balance face-to-face training with online training. It can take a while to reap the benefits of this learning approach.

\section{Lack of motivation}

Not every blended learning model is suited to every person, task, or subject. In the way you consider students' reading levels when choosing books for them, you should consider which approach will work best for them. It's essential to consider these things when you prepare your learning methods and materials.

3. Basic technology knowledge

Participants must have a basic knowledge of technology to take lessons and complete assignments online. Students won't learn too much from a screen if they don't know how to do it or are not interested. This issue can be solved with a quick introduction to the new training techniques and its benefits.

4. Plagiarism and credibility problem

Plagiarism is a well-known issue in the e-learning world. It might be hard for online learners to resist the temptation of looking up things on the web while learning from a computer or smartphone

To conclude, blended learning has its bright and dark sides. The combination of self-paced education and face-to-face training can be beneficial, but only when wisely applied.

\section{References:}

1. Movchan, Sergiy (2018). Advantages and Disadvantages of Blended Learning [Electronic resource]. - Excess code: https://raccoongang.com/blog/advantages-anddisadvantages-blended-learning/ 
2. Pros and Cons of Blended Learning [Electronic resource]. - Excess code: https://www.digitalchalk.com/resources/blog/tips-and-tricks/pros-and-cons-ofblended-learning

3. Winstead, Scott. 6 Disadvantages of Blended Learning You Have to Cope [Electronic resource]. - Excess code: With https://myelearningworld.com/6disadvantages-of-blended-learning/ 


\section{СТОРІНКА 3 ЖИТТЯ ЕЖЕНА СЮ}

Білик Яна Степанівна

к. філол. н., доцент

Вінницький національний медичний університет ім. М.І Пирогова

\section{Лісовий Микола Іванович}

к. пед. н., доцент

Вінницький національний медичний університет ім. M.I Пирогова

Ежен Сю (Марі Жозеф Сю), французький письменник, автор романів соціального та психологічного напрямку; відомий передусім рядом авантюрноекзотичних романів («Атар Гюль», «Кукарача», «Саламандра» та ін.), опублікованих у 30-х роках 19 століття, а також започаткованим ним новим жанром літератури, аналогом сучасних серіалів, карно-сенсаційного жанру масової літератури. Популярність йому приніс соціальний роман «Паризькі таємниці» (1842-1843), за яким вийшли друком «Агасфер» (1844-1845) i «Таємниці народу» (1849-1856). Зображуючи зі співчуттям страждання й бідування народних мас, людей так званого «паризького дна», Ежен Сю підхопив соціалістичну тенденцію у французькій культурі 40 -х років. У сентиментальноміщанському дусі трактував соціальні ідеї Шарля Фур'є, французького представника утопічного соціалізму, засновника системи фур'єризму, послідовників якої називали фур'єристами. Соціалізм письменника був неглибокий: народ зображувався як пасивна маса, нездатна на самостійну історичну діяльність. I вже в другій половині XIX століття популярність Сю швидко зійшла нанівець.

Ежен Сю прожив кілька життів: першу - письменника-мариніста в дусі Клода Фаррера (письменника, автора морських романів); другу - як світський романіст; третю - соціалістичного пророка, якого обожнював народ. Критика спочатку надмірно возвеличувала його. Шарль Огюстен де Сент-Бев (літературознавець, літературний критик, засновник власного методу, який в подальшому був названий «біографічним») ставив письменника в один ряд з Оноре де Бальзаком. А пізніше, коли Ежен Сю звернувся до жанру популярного роману-фейлетону, та ж сама критика й скинула його в пекло комерційної літератури, проявивши жорстоку несправедливість. I тим не менше в житті Ежена є якась цілісність. Індивід зазнає змін, але попри всі ці метаморфози в ньому зберігається щось стабільне. Однак, ця цілісність особистості нерідко є глибоко прихованою. Що ж спільного між Еженом Сю - гульвіси, який вештається між майстернями художників і медичним факультетом, набуваючи популярності скандальними витівками; денді в жовтих рукавичках, який колекціонує дорогоцінні дрібнички, коханцем герцогинь, одним із стовпів жокей-клубу; i, нарешті, романістомлюдинолюбцем, що відвідує мансарди та халупи? Журналіст і кінокритик ЖанЛуї Борі виявляє протягом всього життя письменника деякий постійний стан 
розуму, внутрішній протест, що пояснюється, з його точки зору, комплексом опору батькові, який виник ще в дитинстві [3, с. 638].

Його «Артур» - історія скептика, розореного скептицизмом; нова форма опору батькові. Це зведення рахунків. Перша частина - чорна, друга - ii абсолютна антитеза - біла: живописання жертви-пролетаря. Викриття міфу вищого світу, твердження міфу народу; на цьому взаємодоповнювальному русі згодом вибудується міфологія «Паризьких таємниць».

Якщо творчий шлях письменника пояснюється, з одного боку, постійністю характеру, то, з іншого, відому роль тут відіграє і випадок. Преса з'ясувала, що романи, які публікуються 3 номера в номер, забезпечують постійних передплатників. «Артур», а за ним «Матильда» - роман на захист розлучення (став відомим навіть у Росії; перекласти його планував Ф. Достоєвський) - мали як в газетах, так і пізніше в окремому виданні величезний успіх, що втішило i заспокоїло зневіреного Ежена (у 1830-х роках, вдосталь надивившись реалій «еліти», звертається до соціальної прози й жорстокої сатири на дворянство. Ображені літературною уїдливістю буржуа чинять змову проти письменника, що призводить його до зубожіння й спустошення). Згодом, у 1841 році, подивившись в театрі «Порт-Сен-Мартен» п’єсу Фелікса Піа «Два слюсарі», в якій були показані злидні й людська гідність народу, він особисто зустрівся 3 автором і привітав його. На Сю ніби зійшло осяяння. «Так, до цих пір ви бачили тільки світ мертвий - аристократію або той, який вмирає буржуазію. Я показую вам світ, який прийде», - відповів Піа [3, с. 638], і запропонував пообідати разом в одного паризького робітника. Як перст долі, як любов з першого погляду... Ежен відразу захопився доброчесним красномовним пролетарем. Речі харизматичного робітника Фюжера, «нищівника крамарів, розтрощили самого денді», змусили письменника інакше подивитися на робочий клас. Письменнику було близько сорока і він відчував потребу мати опору в чомусь серйозному. Але ні про католицизмі, ні про добропорядну золоту середину не могло бути й мови. Отже, чому б не соціалізм? I Сю, в глибині душі людина великодушна, цілком віддається чутливому милуванню. Він побачив зворотний бік декорацій - злидні, точно так, як пізніше відкрили іiі для себе Віктор Гюго і Чарльз Діккенс. «Я соціаліст». Ежен стане на захист простого народу і звинуватить у всіх його нещастях аристократію.

Однак при цьому Ежен залишається денді. Злиття цих двох основ і принципів пізніше реалізується в образі Родольфа в «Паризьких таємницях» - князь, захисник знедолених, спонукуваний милосердям і почуттям справедливості, він розправляється з кривдниками власними кулаками, він - чемпіон з боксу, вільної боротьби й фехтування, денді, що не боїться зчепитися урукопаш зі злочинцями. Ідея виникнення роману, який приголомшив Францію й світ, прийшла випадково, після того, як книготорговець Гослен показав письменнику ілюстроване англійське видання «Лондонських таємниць», зауваживши, що дещо подібне, зроблене на паризькому матеріалі, може мати всі шанси на успіх. Звісно, Сю поставився до ідеї стримано. Проте, вивчаючи паризьке «дно», спочатку 3 огидою, пізніше захопився цим більше. Фур'єристи вітали письменника $з$ тим, що той викрив жахливі факти. Надходили листи, численні. 
Він відчув підтримку громадської думки. Люди, подібні Сю, небайдужі до успіху і не вагаючись ідуть за ним. «Авантюрні дослідження» повертають Сю до Фенімора Купера періоду літературних дебютів. А Дюма напише згодом «Паризьких могікан» (Ежен Сю його випередив). Одягнений в робочу блузу, 3 каскеткою на голові, супроводжуваний другом-силачем і своїм тренеромбоксером, Сю відвідує злакові місця, кабаки, злодійські кубла. Він повертається звідти з «мисливською торбою», набитою «безсмертними» типами: Флер де Марі, Шурінер, Учитель, Сичиха, Зозуля [2].

Шокований Сент-Бев перестає його хвалити і стверджує, що філантропічні глави роману додані автором лише для того, щоб прикрити гнойові купи, трюмний сморід і «пріапічні сцени» ... [1, с. 640]. Але ця іронія недоречна; прямий результат «Паризьких таємниць» - перехід автора до нової віри через його власний твір

«Салонний красень» стає романістом для народу. Звідси «Вічний жид», що припав до смаку антиклерикальному середовищу. Після революції 1848 року легітиміст, який перетворився на переконаного соціаліста, буде обраний депутатом Національних зборів від Парижа і в момент державного перевороту доведе свою республіканську мужність... Через протести проти перевороту Наполеона III письменник добровільно стає вигнанцем, опиняється в Савойї, яка на той час не входила до складу Франції (область Савойя увійшла до складу Франції тільки у 1860 році).

Ж.-Л. Борі хвилююче описав останні роки життя письменника. Останньою його нерозділеною любов'ю була дивна і спокуслива жінка - Марі де Сольм, внучка Люсьєна Бонапарта (брата Наполеона), яка була закохана у Франсуа Понсара, драматурга, представника так званої школи «здорового глузду» [2].

. У 1857 році Ежен Сю завершує «Народні таємниці» у 16 томах, які не йдуть в жодне порівняння 3 «Паризькими таємницями». У своєму прощальному зверненні до читачів він стверджує, що ця книга була йому продиктована громадянським обов'язком. Сю стає захисником бідного класу, стверджуючи, що за людські вади несе відповідальність саме суспільство, а не тільки конкретна людина. Але опублікувати роман за життя письменника заважала цензура. Письменника звинуватили в закликах до повалення влади, популяризації насилля та соціалістичних ідей.

Ежен помер в образі бійця, з притаманними бійцеві чеснотами і слабкостями. Відомі й популярні серед читачів твори письменника «Паризькі таємниці» (18421843), Вічний жид» (1844-1845), «Таємниці народу» (1849-1957) написані в жанрі фейлетону; друкувалися в газетах, тираж яких був більшим у 20 разів на той час. За роки активної літературної діяльності Сю ідеально відточив майстерність підтримувати інтригу і вивів драматичну складову на новий рівень. Сам адаптував для сцени свої гучні романи «Вічний жид», «Матильда», «Паризькі таємниці» та ін. Прихильник ідеї, що індивідуальна моральність умовна, а за злочин проти закону і людини є відповідальним усе суспільство. Також він вперше використав у літературі афоризм «Помста - це блюдо, яке слід подавати холодним» [3, с. 33]. 
Сімома роками раніше помер Бальзак. Відкрився шлях «новому роману». У тому ж 1857 році на цей шлях стає Гюстав Флобер зі своєю «Мадам Боварі».

\section{Список літератури:}

1. Моруа Андре От Монтеня до Арагона. Москва : Радуга, 1983. 687c.

2. Тарасов А. Н. Неизвестный Эжен Сю. Страна Икс. Москва : АСТ; Адаптек, 2006. URL : http://left.ru/2001/6/sue19.htm (дата звернення 05.03.2021).

3. Фролова Р. И. Э. Сю в русской литературе и критике. Романтизм и реализм 8 литературных взаимодействиях. Казань : Изд-во КГУ, 1982. С. 32-43. 


\title{
ФОРМУВАННЯ МОВИ ФАХІВЦЯ ЗА ДОПОМОГОЮ КОМБІНАТОРНОГО СЛОВНИКА
}

\author{
Киселевич Ірина Валентинівна \\ старший викладач \\ кафедри загальноправових \\ та соціально-гуманітарних дисциплін \\ Херсонський факультет \\ Одеського державного університету \\ внутрішніх справ \\ Україна
}

Вивчення іноземної мови у вищому юридичному навчальному закладі має свої особливості. Актуалізація й інтерактивність термінів є одними 3 них. Засвоєння термінів $є$ обов'язкова умова професійної філологічної компетентності майбутнього юриста [1, с. 11].

Введення і засвоєння термінологічних одиниць вимагає спільної плідної роботи викладачів, курсантів і студентів не тільки в аудиторії, але й поза ії межами. Надзвичайно важливим фактором формування професійної компетентності курсантів i студентів на заняттях 3 іноземної мови за професійним спрямуванням $є$ робота 3 тематичними текстами й пояснення загальних морфологічних, синтаксичних та інших спеціальних категорій, у процесі яких формується базовий лексичний запас [6, с.10]. Той, хто навчається, має знати: 1) як правильно вимовляти і писати термін; 2) чи має термін будь-яку граматичну особливість (вживання іменника police поліuія тільки у множині, а іменника evidence свідчення - в однині; чи прикметник вимагає після себе прийменників, які змінюють його значення (responsible for вiдповідальний за щзось; responsible to nidзвітний комусь); 3) як поєднується термін 3 іншими словами (to protect a citizen, але to enforce a law); 4) основні словотворчі афікси (unlawful протиправний, irregular неправильний, illicit незаконний, imprisonment ув'язнення, inviolable недоторканний, reckless відчайдушний, boldly зухвало, presumption презумпиія) [4, с. 185]. Кожна 3 наведених категорій $є$ дуже важливою й заслуговує ретельного вивчення, однак сучасні тези присвячені питанню формування комбінаторного словника майбутніх правознавців як одному з найперспективніших шляхів презентації нових і засвоєння раніше вивчених лексичних одиниць. Оскільки професійна мова формує фахівців на всіх своїх рівнях і всіма засобами, що має у своєму розпорядженні, тому навчання словосполучень $\epsilon$ дуже продуктивним.

В англійській мові є сталі конструкції граматичного й лексичного рівнів. Граматичні фразеологізми - це фрази, які складаються 3 домінантних слів (іменників, прикметників, дієслів) й граматичних структур [5, с. 86]. Будь-яка людина, яка розмовляє англійською мовою, відчуває, що компоненти фраз to account for, to accuse somebody of, to adapt to, to agonize over, to aim at [2, c. 15-17] пов'язані один з одним. Для носіїв англійської мови будь-які зміни в таких 
фpazax: to arrive at a verdict, to cause damage to, to do damage to [4, с. 185] $\mathrm{\epsilon}$ неприйнятними. До фразеологізмів належать і фрази, які складаються 3 іменників та підрядного сполучника that: we reached an agreement that the barrister would represent us in court; the officer took an oath that he would do his duty professionally. Сталі фрази можуть складатися з прийменників в поєднанні 3 іменниками: by accident, to somebody's advantage, on somebody's advice, in agony, on (under) penalty of death [2, c. 18-19].

Наступна група - конструкції з прикметниками й прийменником of: it was criminal of him to do that; they are confident of him. Слід звернути увагу, що той самий прикметник може мати таке саме значення у конструкціях: it was difficult to convince them, they were difficult to convince, в яких можна використовувати прикметники easy, hard, impossible. Крім того, багато прикметників, що вживаються з прислівниками too, enough, утворюють фрази з інфінітивом: it was too unjust of him to accuse you in committing the crime [5, c. 87].

Англійській мові притаманні фрази, в яких після дієслів вживаються дієприкметники теперішнього часу: they enjoy doing something; he kept talking; she regrets living far from home. Такі фрази як he started investigating the crime; he started to investigate the crime є синонімічними, однак деякі дієслова мають різне значення у різних конструкціях: he remembered to tell them означає, що він мав на увазі розповісти їм і розповів, а he remembered telling them означає, що він пам'ятав, як він їм про це розповів. Так само конструкція he forgot to tell означає, що він збирався їм щось розповісти, але забув про це; he forgot telling them означає, що він забув, що розповідав їм [5, с. 88].

Перехідні дієслова вживаються з прямими додатками і прикметниками: we found evidence interesting [1, c. 45], the police set the prisoner free [1, с. 67], з двома додатками: the police fined him ten dollars [3, с. 53], God will forgive them their sins [3, с. 209]. Ці фрази можна вжити й в пасивній формі: he was fined ten dollars [3, c. 53], they will be forgiven [3, c. 209].

Лексичні фразеологізми мають у своєму складі дієслова (часто перехідні) 3 іменниками: to come to an agreement [6, с. 77], to reach a verdict [6, с. 80], to inflict a wound [6, с. 123], to pay the penalty [6, c. 115], to commit murder [6, c. 164].

В англійській мові можна сказати: to commit fraud [3, с. 43], to perpetrate fraud [3, с. 45], to commit suicide [3, с. 47], але не можна сказати to perpetrate suicide [3, c. 76]. Також заслуговують на увагу поєднання line у ролі іменника або дієслова з іншими частинами мови: to draw a line, to form a line, to line up, to drop somebody a line [2, c. 167].

На відміну від дієслова condemn, яке може поєднуватися з необмеженою кількістю іменників: to condemn abuse (murder, abduction, violence, behavior, policy) [3, с. 122], дієслово commit може вживатися тільки з іменниками, що означають crime або wrongdoing: to commit an offence (delinquency, felony, misdemeanor) [3, c. 134].

В англійській мові часто можна зустріти фрази, які складаються з дієслів, що означають «викорінення/знищення» та іменників: to reject an appeal [6, с. 263], to break a code [6, c. 274], to repeal a law [6, c. 313], to suspend martial law [6, c. 314], to crush resistance [6, c. 343], to override a veto [6, c. 389]. 
Також іменники можуть виконувати функцію прикметників: traffic controller [1, c. 46], life sentence [1, c. 56], house arrest [1, c. 127], land reform [6, c. 223], aptitude test [1, c. 78], death penalty [1, c. 80], court justice [1, c. 132], drug pusher [3, c. 172].

До наступної групи належать лексичні словосполучення прислівників 3 прикметниками: strictly accurate [3, с. 55], closely acquainted [6, c. 130], keenly aware [1, с. 76] та дієслів з прислівниками: to affect deeply [2, с. 14], to appreciate sincerely [2, c. 22], to argue heatedly [2, c. 24].

Для оволодіння мовою як засобом професійного спілкування $\epsilon$ перспективним використання англійських комбінаторних словників, що сприяє формуванню навичок використання усталених словосполучень в усному й писемному мовленні. Систематична робота 3 такими словниками допомагає створювати загальну з носіями мови лінгвістичну й екстралінгвістичну базу для оволодіння мовою міжкультурної комунікації [5, с. 89].

\section{Список літератури:}

1. Афендікова Л. А. Англійська мова для юристів. - Донецьк: Центр підготовки абітуріснтів, 1998. - 188 с.

2. Бенсон М., Бенсон Э., Илсон Р. Комбинаторный словарь английского языка. М.: Русский язык, 1990 - 286 с.

3.Зеленська О. П. Туреs of Crimes. Навчальний посібник з англійської мови. - К.: Видавництво Європейського університету фінансів, інформаційних систем, менеджменту і бізнесу, $1999-278$ с.

4. Карабанова Л. М. Навчання професійного вокабуляра юриста // Проблеми культури професійної мови фахівця: теорія та практика. Матеріали VI міжвузівської науково-методичної конференції. - Донецьк: Вид-во Донецьк. юридичного інституту при ДонНУ, 2006. - С.185-187.

5. Яковлєва М. М. Формування мови фахівця за допомогою комбінаторного словника // Проблеми культури професійної мови фахівця: теорія та практика. Матеріали VIII міжвузівської науково-методичної конференції. - Донецьк: Видво Донецьк. юридичного інституту при ДонНУ, 2008. - С.85-89.

6. English for Law Students. Підручник з англійської мови для студентів I-III курсів юридичних спеціальностей вищих навчальних закладів за загал. ред. проф. В. П. Сімонок. - Харків: Право, 2006. - 415 с. 


\title{
ПОЭТИКА НОВОГОДНИХ РАССКАЗОВ А. П. ЧЕХОВА
}

\author{
Краснопеева Алина Александровна \\ магистрантка \\ Черкасский национальный университет имени Богдана Хмельницкого
}

Новогодние рассказы в творчестве А. П. Чехова составляют интересный и не до конца исследованный пласт. Являясь одной из групп святочных рассказов, они, тем не менее, отличаются оригинальностью стиля и социальной направленностью. Их тематика зачастую касается области морали и нравственности, веры и неверия, наличия «осмысленной религиозной позиции» [1, с. 288] или ее отсутствия. Вероятно, это связано со строгим религиозным образованием, которое получил писатель в детстве; с «хорошей эрудицией в области религии» [1, с. 288]; с внутренними противоречиями, господствовавшими в душе самого писателя.

Изучению жанрового и художественного своеобразия святочных рассказов в творчестве А.П. Чехова посвящено немало работ (И. А. Есаулова, Е. В. Душечкиной, К. Н. Разумовской, В. В. Кондратьева, Н. В. Капустина, А. В. Кубасова, П. Н. Толстогузова, А. С. Собенникова, Н. В. Самсоновой и др.), однако поэтика новогодних рассказов, составляющих целую группу, на наш взгляд, изучена недостаточно.

Цель исследования - проанализировать поэтику новогодних рассказов А. П. Чехова.

А. П. Чехов написал более 60-ти рассказов, приуроченных к разным календарным праздникам. Рассказы «Праздничная повинность» (1884) и «Новогодняя пытка» (1887) приурочены к празднику Нового года. События в рассказе «Сон» происходят в ночь под Рождество. Рассказы «Студент» (1894) и «Святою ночью» (1886) приурочены к празднику Пасхи. Святочные рассказы появляются в творчестве писателя, когда этот жанр в русской литературе уже сформировал определенные каноны: заданное время, четкая композиционная структура, известные мотивы. Н. С. Лесков очертил эти условия достаточно четко: «От святочного рассказа непременно требуется, чтобы он был приурочен к событиям святочного вечера - от рождества до крещенья, чтобы он был сколько-нибудь фантастичен, имел какую-нибудь мораль, хоть вроде опровержения вредного предрассудка, и наконец - чтобы он оканчивался непременно весело» [2, с. 433]. Следствием такой регламентированности, по словам Е. В. Душечкиной, «явилась заштампованность текстов и их относительное сюжетное однообразие $<\ldots$.. $>$ что неизбежно привело к созданию различного рода пародий» [3, с. 229].

Первые святочные рассказы А. П. Чехова были написаны в юмористическом ключе, и связаны не столько с данью литературной традиции - приурочивать отдельные сюжеты к рождественским выпускам журналов, сколько с желанием изменить и обновить жанр. Среди них обнаруживаются рассказы, которые, с одной стороны, имеют прямое отношение к святочным (новогодним), а с другой, 
- достаточно далеки от канонов, определенных Н. С. Лесковым. В этом ряду стоят рассказы «Либерал» (1883), «Орден» (1883), «Праздничная повинность» (1885), «Новогодние великомученики» (1886), «Новогодняя пытка» (1887).

Объединяет рассказы «Либерал», «Новогодняя пытка», «Праздничная повинность», «Новогодние великомученики» новогодний хронотоп. Об этом мы узнаем или из названия, ориентирующего на определенное прочтение произведения, или из его начала: «в первый день нового года» («Либерал»), «был новогодний полдень» («Праздничная повинность»). То есть, время действия предпраздничное или праздничное, связанное с суетой, подготовкой к торжеству, и одновременно - с ожиданием чуда. Однако в чеховской интерпретации - это время превращается, скорее, в тяжелую обязанность, навязанную обществом.

Герои рассказов - «визитёры» - мелкие чиновники (губернский секретарь, учитель военной прогимназии, старший советник, титулярный советник), которые по ряду причин вынуждены ходить с визитами к своим начальникам. Причины эти очень обыденные: боязнь потерять работу, желание угодить, в знак благодарности за одолженные деньги, за место службы и просто потому, что так принято. Жена героя рассказа «Новогодняя пытка» говорит мужу: «Кузина Леночка так нас любит, и ты, бесстыдник, не хочешь оказать ей честь? Фёдор Николаич дал тебе денег взаймы, брат Петя так любит всю нашу семью, Иван Андреич нашёл тебе место» [4, V, с. 5]. А герой рассказа «Новогодние великомученики» на предложение полицейского врача пойти домой отдохнуть, со стоном отвечает: «Нельзя мне домой... Нельзя мне домой... Как можно с Новым годом не поздравить? Нужно-с... Не сходи к Наталье Егоровне, так жить не захочешь... Уж вы меня отпустите, г. доктор, не невольте...» [4, XII].

Иногда чиновники «протестуют» против таких «визитов»: «Я образованный человек и не желаю подчиняться невежеству! Иди сама расписывайся, если хочешь, а меня оставь!.. Не желаю быть в рабстве», говорит герой рассказа «Либерал» своей жене. Однако этот протест недолгий и сопровождается душевными страданиями героя и самонаказанием: «Скотина я, скотина! проворчал он. - Протестуй ты, осёл, ежели хочешь, но не смей не уважать старших!» [4, II, с. 271].

Видимо, этот праздник, когда «все радовались, ликовали, поздравляли друг друга. Воздух оглашался самыми искренними и сердечными пожеланиями. Все были счастливы и довольны» [4, II с. 268] («Либерал») утратил свой первоначальный смысл, превратился в повинность, стал внешним атрибутом.

Подтверждением тому, что праздник изменил свое сакральное значение, являются «говорящие» фамилии - особенность стиля писателя. Они создают комический эффект, служат для характеристики героев, определяя «социальный контекст жизни этого человека» [5, с. 94]: Понимаев, Черносвинский, Пустяков, Трамблян, Окуркин, Подсилкин, Прорехин, Лягаво-Грызлова и др. Эта особенность, на первый взгляд, никак не связана со святочными рассказами, однако расширяет его содержательное наполнение.

Еще одной особенностью чеховских новогодних рассказов является специфическая сюжетная организация: если в традиционном святочном рассказе 
повествование организует сюжет, то у Чехова движущим фактором в развитии сюжета является диалог. Например, в рассказе «Новогодняя пытка» Чехов как бы возвращается к новогодним визитам, рисует их ужасающие картинки, встраивая в диалог: «Вы облачаетесь во фрачную пару, нацепляете на шею Станислава, если таковой у вас имеется, прыскаете платок духами, закручиваете штопором усы - и всё это с такими злобными, порывистыми движениями, как будто одеваете не себя самого, а своего злейшего врага. - А, чёрррт подери! бормочете вы сквозь зубы. - Нет покоя ни в будни, ни в праздники! На старости лет мычешься, как ссобака! Почтальоны живут покойнее!». Автор описывает ситуации посещения одна за одной, как бы «нанизывая» те отрицательные чувства, которые испытывает герой: «от обалдения у вас начинают чесаться мозги», «слёзно просите обождать ещё месяц», «красный, вспотевший вы выходите от него», «вы что-то бормочете, беспомощно поглядываете по сторонам», «ещё минута, и вы с отчаяния броситесь в горящий камин, головой прямо в уголья», «разбитый, помятый, без задних ног возвращаетесь вы к вечеру домой» $[4, \mathrm{~V}$, с. 5-6]. Казалось бы, это конец, сейчас все закончится, но далее предстоит разговор с женой, такой же бессмысленный, глупый, полный упреков и обид: «Вы таращите глаза, крякаете и в обалдении встряхиваете головой... Вы молчите?! Не отвечаете? - продолжает супруга. - Нет? Уми... умираю! До... доктора! Заму-учил! Уми-ра-аю!». Финал рассказа - неожиданный, но именно он создает ту иронично-юмористическую атмосферу, которая вызывает, с одной стороны, смех, а с другой, грусть: «Теперь, милый мужчина, одевайтесь и скачите за доктором. С Новым годом!» [4, V, с. 10].

Итак, мы можем представить результаты сравнения традиционной схемы святочного рассказа и рассказов А. П. Чехова в следующей таблице:

\begin{tabular}{|c|cc|}
\hline $\begin{array}{c}\text { Традиционный святочный } \\
\text { рассказ }\end{array}$ & \multicolumn{3}{|c|}{ Святочный рассказ А. П. Чехова } \\
\hline $\begin{array}{c}\text { Время действия - от } \\
\text { Рождества до Крещения }\end{array}$ & Приуроченность к Новому году & не \\
\hline $\begin{array}{l}\text { Наличие } \text { элементов } \\
\text { фантастики }\end{array}$ & $\begin{array}{l}\text { Использование фантастики } \\
\text { обязательно }\end{array}$ \\
\hline Должен содержать мораль & $\begin{array}{l}\text { Праздник Нового года утратил свой } \\
\text { первоначальный смысл, превратился в в } \\
\text { повинность, стал внешним атрибутом }\end{array}$ \\
\hline Счастливый финал & $\begin{array}{l}\text { Неожиданный финал, создающий } \\
\text { иронично-юмористическую атмосферу }\end{array}$ \\
\hline
\end{tabular}

Таким образом, изучение поэтики новогодних рассказов А. П. Чехова представляет значительный интерес в литературоведении, поскольку позволяет проанализировать оригинальные образцы жанра святочного рассказа в целом. Главной особонностью чеховских рассказов является то, что в них на первое место выдвигается социальный контекст, а привычная семантика чуда обрастает комическим эффектом (особенно в ранних произведениях). 


\section{Список литературы}

1. Родионова И.О. А.П.Чехов: мысли о религии и некоторых других предметах. Вестник Русской христианской гуманитарной академии. 2013. Том 14. Выпуск 4. С. 283-292.

2. Лесков Н.С. Собрание сочинений в 11 томах. Т. 7. Москва : Изд-во Худ. лит-ры. 686 с.

3. Душечкина Е.В. Русский святочный рассказ: становление жанра. СанктПетербург: Изд. отдел Языкового центра СПбГУ, 1995. 258 с.

4. Чехов А. П. Собрание починений : в 12- ти тт. М. : Худ. лит., 1954.

5. Мачильская Д.О. Лексические средства организации начала художественного текста (на материале прозы А.П.Чехова): дис. канд. филол. наук : 10.02.01 / Саратовская государственная юридическая академия. Саратов. 2018. $287 \mathrm{c}$.

URL:

https://www.sgu.ru/sites/default/files/dissertation/2018/02/22/dissertaciya_machilsko y.pdf. (дата звернення: 26.02.2021). 


\section{ТЕРМННОЛОГІЗАЦЯ ЗАГАЛЬНОВЖИВАНӦ̈ ЛЕКСИКИ (НА ПРИКЛАДІ ТЕРМННОСИСТЕМИ ГАЛУЗІ ТУРИЗМУ)}

Матвіяс Ольга

ст. викладач

Львівський державний університет фізичної культури імені Івана Боберського

Базиляк Наталія

к. пед. н., доцент

Львівський державний університет фізичної культури імені Івана Боберського

Будзин Віра

к. фіз. вих. і спорт. н., доцент

Львівський державний університет фізичної культури імені Івана Боберського

Спостереження В. В. Виноградова щодо «прямого і тісного зв'язку» «між словником науки і словником побуту» $[1,6]$ п ідтверджується явищем гіперактивного процесу термінотворення $[2,65 ; 3,106-108]$, зумовленого стрімкою появою вузьких термінологічних систем і підсистем. У процесі термінологізації одиниць загальновживаної лексики перетинаються фактори екстралінгвістичної і внутрішньомовної дійсності. Науково-технічний прогрес породжує нові поняття, тим самим зумовлюючи потребу у номінативних ресурсах, які забезпечуються використанням слів загального вжитку у функції термінів. Про актуальність проблеми свідчить той факт, що нові термінологічні системи і підсистеми також використовують загальновживані лексичні одиниці як назви спеціальних понять (наприклад, у термінології галузі туризму: road, room, guest, stuff, check, transfer тощо [4]).

Об'єктом дослідження $\epsilon$ англійські терміни галузі туризму.

Предметом дослідження $\epsilon$ способи термінологізації загальновживаної лексики.

Матеріалом дослідження слугували термінологічні одиниці галузі туризму зафіксовані у словнику Dictionary of Leisure, Travel and Tourism 2008 року видання, який містить понад 9 тисяч статтей.

Оскільки між загальновживаними словами і термінологічною лексикою можливі три типи співвідношень [5, 68]: 1) лексична одиниця не виступає у ролі терміна; 2) лексична одиниця функціонує тільки як термін; 3) лексична одиниця використовується і як термін, і як загальновживане слово, об'єктом нашого дослідження стали двопланові (В. Г. Гак) мовні одиниці. Функціонуючи як терміни вони представлені у спеціальних словниках. Одночасно вони фіксують вплив екстралінгвістичних факторів на семантику загальновживаної одиниці, iї структуру й особливості. Наприклад лексеми, які позначають природне явище water, ice, snow; географічні поняття peak, mountain, ocean, beach, sea, slope; житло room, house, абстрактні поняття тощо складають першу групу термінів і 
називають такі поняття, що одночасно (при різному підході до них) і побутовими i фаховими, тобто виступають носіями двох типів інформації загальновживаного і термінологічного значень. 3 точки зору мовознавчої науки ці одиниці втілюють положення О. О. Потебні про «ближче» і «дальше значення» слова. Перше належить мовознавству, тобто фіксоване загальним тлумачним словником, друге становить предмет іншої науки, у нашому випадку туризмознавства, тобто має термінологічне значення. Цілком логічно, що у процесі історичного розвитку поняття зазнають змін, рівно ж як і зазнають змін співвідносні їм значення мовних одиниць. Причому дуже помітний своєрідний рух загальновживаного значення до термінологічного, тобто збагачення першого елементами фахової інформації. Порівняймо room - a part of a building that has its own walls, floor and ceiling and is usually used for a particular purpose i room -a bedroom in a hotel, причому нові термінологічні складові значень таких одиниць виявляються на синтагматичному рівні, тобто у різній сполучуваності даного терміна, скажімо: room and board, room attendant, room clerk, room expence, room inspection, room key, room linen, room maid, room makeup, room number, room occupancy, room phone, room rate, room reservations, room safe, room sales, room service, rooms payroll, room status board, room tax, room temperature. У лексиці загального вжитку слово room головно сполучується 3 прикметником чи означувальним словосполученням cosy room, light room, clean room, special room, children's room. Як бачимо, сполучуваність загальновживаного слова у функції терміна визначена місцем і роллю позначуваного ним поняття у чітко окресленій системі понять термінології галузі туризму. Вона інша у одноіменних спеціальних назвах терміносистеми галузі туризму у порівнянні 3 словом загальновживаної лексики.

Другу групу термінів утворюють двопланові одиниці, які можуть співвідноситися із різними означуваними. Наприклад apron - a piece of cloth worn over clothes to protect them when working i apron - AIR TRAVEL a piece of tarmac on which planes can be parked for unloading, waiting, cleaning, etc.

Функціонування у ролі термінів другої групи пов'язане 3 повним переосмисленням їхньої семантики. Найчастіше його зазнають:

- назви представників тваринного і рослинного світу;

- назви органів, частин тіла живих істот;

- назви одягу та його елементів;

- назви прикрас;

- назви харчових продуктів;

- назви предметів побуту тощо.

Причина виникнення таких одиниць у мові лежить у площині екстралінгвістичної дійсності, а саме у зіставленні нового поняття *(ще не названого) з уже відомим через якусь спільну для обох ознаку. Звідси у процесі вторинної номінації за даними одиницями закріплюється новий зміст. Зрозуміти шляхи виникнення нових термінологічних значень досліджувальних одиниць можна через зіставлення їх предметно-поняттєвої спрямованості у побуті і фаховій термінології галузі туризму. Явищами метафори, метонімії і синекдохи власне і пояснюється поява нового термінологічного поняття і разом 3 тим 
розвиток багатозначності слова. Переосмислення загальновживаного значення відбувається за різними ознаками, скажімо: подібність форми, подібність за функцією, подібність за використанням. Термінологічне значення (похідне переносне) мотивоване загальновживаним (головним прямим).

BANK

1 - a business which holds money for its clients, which lands money at interest

2 - entertainment -the money held by the organizer in a gambling game

BARBECUE

1 - food cooked in the open air

2 - a party

$\mathrm{BOX}$

$1-$ a container

2 - entertainment - a special sector in a theatre, with chairs for two or three spectators CELLAR

1 - an underground room

2 - wine stored in a cellar

CLEARANCE

1 - the act of removing something dirty

2 - air travel - permission to take off

\section{LINER}

1 - a large passenger ship

2 - catering- a dish on which another dish is placed containing food ready for serving LINEN

1 - a cloth made from flax

2 - household- sheets, pillowcases, tablecloths

MEASURE

1 - a way of calculating size or quantity

2 - beverages - a serving of alcohol or wine when served in a glass

MILL

1 - to grind grain or seed in a machine

2 - to whisk or shake something such as cream or chocolate until it is foamy

PASS

1 - an act of going or moving past or over something

$2-$ a bus or train season ticket or a permit to go in or out

3 - a road or way over or through mountains

Отже, явище термінологізації - складний семантичний процес, проникнення у суть якого розкриває одну із сторін значеннєвого розгалуження слова. Однак доволі складно досліджувати процес термінологізації загальновживаної лексики саме на прикладі терміносистеми галузі туризму, оскільки вона охоплює терміни уже існуючі у таких галузях як економіка, транспорт, спорт, дозвілля та розваги, харчування, медицина, релігія, а також безпосередньо торкається термінології наук таких як історія, географія, геологія, біологія, археологія тощо. 


\section{Список літератури:}

1. Виноградов В. В. Основные типы лексических значений слова. - Вопр. языкознания, 1953, № 5, с. 6 .

2. Осипенко 3. М. Різновиди термінів і їх семантичні особливості. Мовознавство, 1974, № 2, с. 65.

3. Кутарева Л. В. Из наблюдений над техническими терминами, образованными путем переосмысления общенародных слов. - Рус.языкознание, 1980, № 1, с. 106108.

4. Гак В. Г. Ассиметрия лингвистического знака и некоторые общие вопросы терминологии. - М., 1971, ч. 1, с. 68. 


\title{
СТВОРЕННЯ МОБІЛЬНОГО ДОДАТКУ В ТРАНСПОРТНИХ СИСТЕМАХ
}

\author{
Колодяжний Володимир Максимович
}

д.фіз.-мат.н., професор кафедри інформатики та прикладної математики Харківський національний автомобільно-дорожній університет

Плсхова Ганна Анатоліївна к.т.н., доцент кафедри інформатики та прикладної математики Харківський національний автомобільно-дорожній університет

Кочусва Зоя Анатоліївна к.т.н., доцент кафедри інтелектуальних комп'ютерних систем Національний технічний університет «Харківський політехнічний інститут»

Розглядаються один 3 можливих напрямів побудови інтелектуальної системи управління транспортними засобами, які дозволяють визначити місцезнаходження транспортного засобу (тролейбуса, автобуса, трамвая) під час руху на маршруті і встановити час прибуття до визначеної зупинки. В багатьох європейських країнах, та і в деяких містах України на зупинках можна зустріти електронні табло, що вказують час прибуття окремого транспортного засобу на визначену зупинку. Зараз мова йде про створення спеціального додатку для мобільного телефону, який буде виконувати функції виявлення де знаходиться відповідний транспортний засіб, який термін йому потрібен, щоб дістатися відповідної зупинки, де його чекає можливий пасажир.

У місті Харків побудовано багато нових транспортних зупинок. Вони можуть бути обладнані спеціальними чипами, які отримують інформацію 3 рухомого транспортного засобу. Кожна зупинка отримує відповідний код, який дозволяє встановити місцеположення цієї зупинки. Пасажир включає додаток мобільного телефону і отримує необхідну інформацію про наявність рухомого транспортного засобу в цей час, можливий напрям руху, початкову та кінцеву зупинки, термін прибуття на зупинку, на якій чекає пасажир, що включив мобільний додаток. Вся необхідна інформація про рух транспортного засобу готується заздалегідь і може змінюватися в автоматичному режимі на основі де розташований транспортний засіб, чи може він продовжувати рух відповідно визначеного напрямку. Вся необхідна інформація готується і передається без участі водія транспортного засобу.

Основні вимоги для виконання функцій мобільного додатку можуть бути наступними: - початковий та конечний час рух транспортного засобу; 
- визначений час прибуття на зупинку, на якій його чекає пасажир; - кількість транспортних засобів, що працюють на маршруті;

- можливість дістатися необхідної зупинку, яка необхідна пасажиру; - час необхідний для прибуття на зупинку, яка потрібна пасажиру; - можливість скористатися іншим видом транспортного засобу, щоб доїхати до зупинки, яка необхідна пасажиру;

- можлива вартість проїзду;

- скільки часу необхідно, щоб подолати відстань між двома зупинками 3 врахуванням часу на висадку-посадку пасажирів; - скільки часу треба для подолання відстані від самого близького транспортного засобу до зупинки, з якої відбувається запит; - та інші вимоги.

Мобільний додаток отримує інформацію з чипа, який розташований на відповідній зупинці, запрошує, яка кількість транспортних засобів працює в цей час на маршруті, коли чекати прибуття транспортного засобу, який задовольняє вимогам пасажира.

Визначений мобільний додаток повинен надавати інформацію про всі можливі транспортними засобами, якими може скористатися пасажир, та можливий напрям руху, щоб дістатися необхідного для пасажира кінцевого місця розташування.

Для організації функціональної дії мобільного додатку треба скористатися можливостями «StartUp». Побудований мобільний додаток буде затребуваний в багатьох містах нашої країни, які мають розгалужену транспортну систему. 


\title{
МЕТОД ФЛУОРЕСЦЕНТНОЇ ВІЗУАЛІЗАЦЇ̈ НАНОЧАСТИНОК В ТІЛІ ЛАБОРАТОРНИХ ТВАРИН (ОГЛЯД)
}

\author{
Купріянчук Володимир Миколайович \\ аспірант \\ Київський національний університет імені Тараса Шевченка

\section{Будник Микола Миколайович} \\ Д.т.н., с.н.с., професор кафедри \\ Київський національний університет імені Тараса Шевченка
}

Наночастинки застосовуються як для діагностики, так і для конструювання систем спрямованої доставки ліків. Наночастинки можуть бути використані як універсальні засоби для таргетної терапії. Синтезовано багато різних ефективних таргетних систем на основі наноматеріалів, проте не всі 3 них дійшли до клінічного застосування.

Після введення наночастинок в живий організм ми можемо оцінювати результати їх впливу тільки за зовнішніми непрямим ознаками: поведінки тварини, зміни в аналізах крові, посмертних морфологічних змінах в органах $\mathrm{i}$ т.д. Суттєвою проблемою є прижиттєве дослідження біокінетики і розподілу часток нанодіапазону, так як закономірності їх розподілу багато в чому відрізняються в залежності від характеру наночастинок, їх морфології, розміру, заряду та інших властивостей, що ускладнює екстраполяцію даних на інші наноматеріали. Крім того, більшість доступних літературних даних 3 фармакокінетики наноматеріалів базуються на експериментах ex vivo, що супроводжується загибеллю великої кількості експериментальних тварин і не узгоджується 3 принципами біоетики [1].

Більшість сучасних досліджень пропонують використання оптичних методів візуалізації $[2,3]$. Відомо, що більшість органічних речовин в клітинах не поглинають електромагнітне випромінювання в ближній інфрачервоній області, тому область 650-1350 нм отримала назву «вікно прозорості» біологічних об'єктів і може бути використана для візуалізації будь-яких маркерів in vivo.

В якості маркерів використовують різні речовини - флуоресцентні маркери, що демонструють властивість флуоресценції в ближній ІЧ-області. За допомогою флуоресцентних міток можна вивчити розподіл мічених білків в організмі або отримати зображення біомолекул, мічених органел всередині клітини, рецепторів на поверхні клітин, в тому числі пухлинних [2].

Більшість флуоресцентних речовин - низькомолекулярні і водорозчинні, тому їх складно інкапсулювати, часто відбувається незворотна втрата флуорофора в процесі синтезу (витік) або втрата його активності («вигорання») 
[3]. Пришивання флуоресцентно-мічених антитіл до поверхні наночастинок технічно дорого, занадто багато роботи, а також й не забезпечує необхідної концентрації флуоресцентного маркера, а, отже, й достатнього рівня світіння наночастинок в органах і тканинах - візуалізація можлива тільки в мазках або зрізах під мікроскопом [4]. Тому для in vivo досліджень найбільш перспективним напрямком $\epsilon$ розробка флуоресцентних маркерів на основі макромолекули (наприклад, білка).

Використовувалися барвник ціаніновий 7 (СУ7) фірми «LumiprobeCo» $\mathrm{i}$ бичачий сироватковий альбумін (BSA) SigmaAldrich (США). За основу синтезу була взята реакція кон'югації BSA і активованого ефіру СУ7. Були розраховані основні об'єми та співвідношення реагентів згідно з протоколом кон'югації, наведеним в роботі [4]. Білок розчиняли у фосфатному буфері, а барвник NHSСУ7 - в диметилсульфоксиді (ДМСО).

Розчинений барвник доливали до білка, суміш ретельно перемішували на магнітній мішалці, далі проводилася інкубація в різних умовах протягом 24 год. Очищення отриманого кон'югату BSA-CУ7 здійснювали за допомогою діалізу 3 діаметром отворів 12-14 кДа. Діаліз проводився деіонізованою водою при різній температурі і постійному помішуванні. Воду міняли кожні 24 години до досягнення візуально чистого розчину [1].

Після оптимізації методики була досліджена кінетика барвника СУ7 у вільній, кон'югований з білком і ліпосомальній формі. Ліпосоми були обрані в якості моделі частинок в нанодіапазоні як найбільш вивчені і потенційно нетоксичні [5].

Ліпосоми синтезували методом «звернення фаз» з лецитину і холестерину на роторному випарнику Laborota 4000 eco (Heidolph, Німеччина) аналогічно роботі [6]. Отримані ліпосоми мали середній розмір $292 \pm 14$ нм, кількість СУ 7 складає $98 \%$.

Дослідження кінетики виконано на лабораторних мишах масою 18-22 місяців. Було виконано 2 серії експериментів. У першій серії вивчена системна динаміка барвника. У другій серії порівнювався його розподіл по органам методом full body imaging (тобто візуалізація всього тіла тварини).

Результати дослідження впливу температурного режиму на ефективність включення барвника в білок представлені в Табл. 1.

Таблиця 1

Залежність ступеня включення СУ7 від температури

\begin{tabular}{|l|c|c|c|c|}
\hline Температура & $+4^{\circ} \mathrm{C}$ & $+18^{\circ} \mathrm{C}$ & $+25^{\circ} \mathrm{C}$ & $+37^{\circ} \mathrm{C}$ \\
\hline $\begin{array}{l}\text { Концентрація } \\
\text { барвника, мг/мл }\end{array}$ & $0,29 \pm 0,01$ & $0,26 \pm 0,03$ & $0,22 \pm 0,004$ & $0,17 \pm 0,001$ \\
\hline
\end{tabular}




\begin{tabular}{|l|l|l|l|l|}
\hline $\begin{array}{l}\text { Ступінь включення } \\
\text { барвника, \% }\end{array}$ & 99 & 90 & 76 & 60 \\
\hline
\end{tabular}

3 Табл. 1 видно, що оптимальною для інкубації $є$ температура $+4^{\circ} \mathrm{C}$. Тому подальшу інкубацію проводили при даній температурі в холодильнику на магнітній мішалці [1].

Результати експериментів по підбору оптимальних умов $\mathrm{pH}$ для синтезу флуоресцентного маркера BSA-СУ7 представлені в Табл. 2.

Таблиця 2

Залежність ступеня включення СУ7 від $\mathrm{pH}$

\begin{tabular}{|l|c|c|c|c|c|}
\hline \multicolumn{1}{|c|}{$\mathrm{pH}$} & $7,0-7,5$ & $7,6-8,2$ & $8,3-8,4$ & $8,5-8,6$ & $8,7-9,0$ \\
\hline $\begin{array}{l}\text { Концентрація } \\
\text { барвника, мг/мл }\end{array}$ & $0,15 \pm 0,02$ & $0,26 \pm 0,03$ & $0,29 \pm 0,001$ & $0,28 \pm 0,002$ & $0,16,5 \pm 0,001$ \\
\hline $\begin{array}{l}\text { Ступінь } \\
\text { включення } \\
\text { барвника, \% }\end{array}$ & 52 & 90 & 99 & 98 & 61 \\
\hline
\end{tabular}

При низьких значеннях $\mathrm{pH}$ відбувається протонірування аміногруп, внаслідок чого знижується ефективність реакції. При високих значеннях істотним стає процес гідролізу активованого ефіру. 3 Табл. 2 видно, що найбільша ступінь включення барвника була при значенні $\mathrm{pH}$ 8,3-8,6 [1].

Основною метою другої серії експерименту було дослідження розподілу наночастинок (ліпосом), помічених флуоресцентним кон'югатом CУ7-BSA in vivo. Оцінка розподілу по органам барвника проведена в трьох групах мишей (по 5 особин в кожній) на описаній вище установці IVIS Lumina II в режимі full body imaging.

Аналізуючи серію послідовних знімків тварини, якій був введений СУ7 в дозі 5 мкг (1-й ряд), ми можемо бачити, що барвник СУ7 розподілявся в усіх органах і тканинах. На ранніх етапах (30 хв) реєструється люмінесценція печінки, на пізніх - нирок. При введенні аналогічної дози кон'югату (2-й ряд) також спостерігалося світіння як печінки так i нирок, однак інтенсивність люмінесценції була менше.

При цьому максимум інтенсивності світіння печінки був зміщений в область більш пізнього часу спостереження (24 години), а інтенсивність світіння нирок була меншою. Ці дані узгоджуються 3 даними, отриманими при вивченні системної кінетики, і свідчать про те, що при введенні кон'югату частка вільної фракції барвника, виведеної нирками, була менше, а час його циркуляції в крові збільшувався [1].

При введенні ліпосом на основі кон'югату CУ7-BSA на початку експерименту (30 хв) також спостерігалося зменшення інтенсивності світіння 
органів, проте до 8-ї години добре контрастувала печінка, а до 24 години відзначалася інтенсивна флуоресценція як печінки так і селезінки [1].

Як відомо, ліпосомальні везикули, не захищені поліетиленгліколем (ПЕГ), елімінуються 3 кровотоку фагоцитами i транспортуються до органів ендоплазматичного ретикулума (РЕМ), де піддаються депонуванню і повільного метаболізму. Ці зміни швидше за все пояснюють і флуоресценцію області печінки і селезінки, і появу тривалої другої фази виведення ліпосом на основі кон'югату CУ7-BSA. Таким чином, прижиттєвий аналіз розподілу флюоресценного маркера і ліпосом в органах тіла миші, які містять маркер на основі білка i ціанінового барвника 7, дозволив виявити особливості фармакокінетики частинок нанодіапазону (ліпосоми i білковий кон'югат) i показав, що дані досить добре узгоджуються з параметрами системної кінетики ex vivo [1].

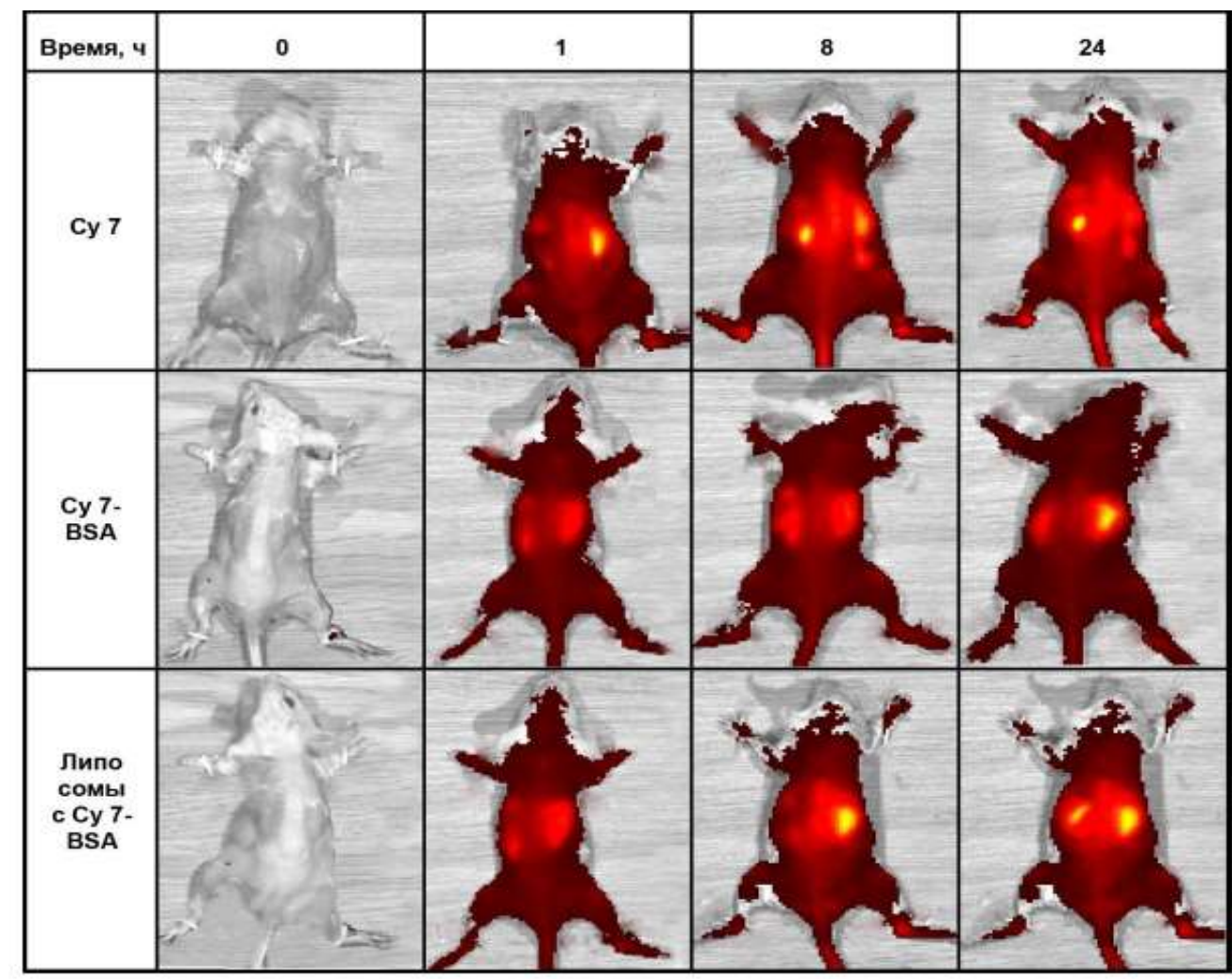

Рис. 1. Візуальні зміна флуоресцентних зображень тіла мишей через 1,8 та 24 години з різними препаратами [1]

Висновки. Розглянуто метод візуалізації розподілу наночастинок в живих організмах за допомогою флуоресцентних маркерів. Була використана флуоресцентна мітка на основі бичачого сироваткового альбуміну та ціанінового барвника 7. Огляд літературних даних показав, що експериментально підтверджені оптимальні значення $\mathrm{pH}$ i температури для кон'югації білка (бичачого сироваткового альбуміну) 3 активованим ефіром ціаніновим 7. Встановлено відсоток включення барвника в отриманому кон'югаті.

В якості моделі наночастинок були застосовані ліпосомальні везикули: отримані ліпосоми 3 лецитину i холестерину 3 включенням отриманого 
кон'югату CУ7-BSA. На основі порівняння даних системної кінетики і даних візуалізації можна зробити висновок про перспективність застосування флуоресцентного маркера на основі бичачого сироваткового альбуміну i барвника ціанінового 7 для візуалізації розподілу органічних і полімерних наночастинок в живому організмі.

\section{Список літератури:}

1. Бродовская Е.П., Минаева О.В., Куликов О.А., Семенова Е.В., Горбунова К.А., Сураева Е.Ю., Кузнецова А.В., Гечас А.А., Кеняйкина А.Г., Кокорев А.В., Пятаев Н.А. Разработка метода визуализации распределения наночастиц в живом организме с помощью флюоресцентного маркера // Современные проблемы науки и образования. - 2019.- №2. URL: http://www.science-education.ru/ru/article/view?id=28772 (дата: 10.03.2021).

2. Alamudi S.H., Chang Y.T. Advances in the design of cell-permeable fluorescent probes for applications in live cell imaging. // Chem Commun (Camb). 2018. Vol. 54. №97. P. 13641-13653.

3. Ueno T., Nagano, T. Fluorescent probes for sensing and imaging. // Nature Methods. 2011. Vol.8. p. 642-645.

4. Corrêa I.R. Jr. Considerations and protocols for the synthesis of custom protein labeling probes. // Methods Mol. Biol. 2015. no 1266. P. 55-79.

5. Yoshimura T., Kurogi K., Liu M.-C., Suiko M., Sakakibara Y. A proteomic approach for the analysis of S-nitrosylated proteins using a fluorescence labeling technique. // Journal of Electrophoresis. - 2016. - Vol 60.- №1.- P. 5-14.

6. Куликов О.А., Агеев В.П., Инчина В.И. Поиск эффективного метода включения флоресцентной метки в состав липосом // Вопросы биологической, медицинской и фармацевтической химии. - 2018.- Т. 21.- № 4.- С. 52-55. 


\title{
PANDEMIC POLITICAL SCIENCE AND CORONAPOLITICS
}

\author{
Vazha Shubitidze \\ Doctor of political science \\ Georgian technical university professor \\ Otar Davitashvili \\ Doctor of history, \\ Georgian technical university professor
}

- On March 11, 2020, the World Health Organization declared the coronavirus (covid 19) spread from China in 2019 as a pandemic and almost all countries of the world became involved in the fight against it;

- The massive spread of the coronavirus (115 million people infected) and the large number of victims (3.6 million people died) forced scientists to study it in depth and start looking for ways to protect themselves from it;

- The coronavirus pandemic has changed the whole world and it will never be the same again. The scientific approach to it is changing accordingly;

- Several scientists working in different countries d. Cohan (USA), PK Aldama (Spain), A. Sulaberidze (Georgia) raised the issue of the need to establish a pandemology of an integrated scientific discipline;

- Pandemology combines current research in medicine, as well as in economics, geo-economics, sociology, psychology, demography, international relations;

- Unlike epidemiology, the object of pandemology research is significantly expanded and derives from the global nature of the modern pandemic;

- Pandemology should study not only the medical field, but also the consequences of changes in economic, geopolitical, psychological, demographic, sociological and other behaviors caused by the pandemic, both globally and locally;

- Therefore, according to Prof. A. Sulaberidze (which we also share and specify) pandemology should be a system of separate branches of science, in which the role of scientific disciplines, subfields will be different. Accordingly, each can be called a field name. E.g. Pandemic Economics, Pandemic Sociology, Pandemic Demography, Pandemic Psychology, Pandemic Geopolitics.

- In our opinion, such a subfield of pandemology can form a pandemic political science, which studies the coronavirus pandemic and its impact on politics through the prism of political theory; 
- Several new terms have appeared in the field of economic science: e.g. Coronamics (Ajit de Alvis, Sri Lanka), Coronanomica, etc.

- In terms of pandemic political science, we are introducing a new term, 'coronapolitics', which examines the impact of the coronavirus on politics (global politics, regional politics) and political crises, limiting the sovereignty of nation-states and especially developing countries.

\section{References:}

1. 1.Урланис В.Ц. Рост населения земного шара. Народонаселение. Иследования, публицистика, М; наука, 2007

2. Qartlis Ckhovre4ba T.2, 1955

3. Brown J. Infuenca: The hundred year hunt to cure the deadliest diseans in history. New York: atria, 2018

4. Giddens A. Risk end responsibility// Modern Law Reviev, 1999

5. Sulaberidze A. Pandemology, Tbilisi, 2021

6. Вахсштеин В. Как пандемия влияет на нашу рутину и обьединиает незнакомых людей https:paperpaper.ru/campus

7. Geller A. Wiseman P. Rugaber C. outbreak Starts to Look More Like Woridwide Ecnomic Grisis, 2020

8. Papava V. Coronomik Grisis: When The Economy Is A Hostage To Medicine. Eurasia Reviev, March 29 https://www.eurasiareview.com 29.03. 2020

9. Cohan D.J. Sociology of the virus assignment, 2020

10. Price Kennex R. Aldama Using sociology to maks sansc of the coronavirus pandemic https//www.rappler.com/views/imho/2559 


\title{
BASICS OF PSYCHODIAGNOSTIC TOOLS FOR STUDYING FEATURES OF SELF-ACTUALIZATION OF PSYCHOLOGISTS IN THE PROCESS OF PROFESSIONAL TRAINING
}

\author{
Bocheliuk Vitalii \\ Dr. in Psychology, Professor \\ «Zaporizhzhia Polytechnic» National University
}

Gaivoronska Taisiia

Ph.D. in Philosophy, Assistant Professor «Zaporizhzhia Polytechnic» National University

Self-actualization is a complex mental activity that requires a clear definition of purpose, significant willpower, directed self-activity, high psychological and energy costs. Prerequisites for self-actualization are:

1) Innate tendency of the individual to growth and development;

2) Contradictions between the available purposes and degree of their realization;

3) Intrapersonal contradictions and external influences that can cause personal crises;

4) Dialectical contradictions between the formation and disclosure of the inner essence, between social and biological, social and individual.

A specific feature of self-actualization of the individual in student age is that it is carried out within the process of professionalization of the individual at the stage of training. This necessitates the addition of a set of properties of self-actualization of future psychologists with those properties that reflect the characteristics of student age and the specifics of professional development of the individual at the stage of university training. As such, properties are socio-psychological adaptability, sociopsychological reflexivity, willingness to self-development, professional identity. An indicator of the effectiveness of the process of self-actualization of future psychologists is the level of development of all the aggregate properties that determine the selfactualization of the individual.

The study of personal characteristics of future psychologists was carried out using methods selected in accordance with the characteristics of self-actualized personality.

We proceed to describe psychodiagnostic tools.

Methodology «Diagnosis of socio-psychological adaptation» developed by K. Rogers and R. Diamond. The basis of this technique is a model of human relations with the social environment and with himself, which is due to the concept of personality as a subject of their own development, able to be responsible for their own behavior. The questionnaire contains statements about the person, about his way of life, experiences, thoughts, and habits, styles of behavior, which the respondent can compare with his 
own way of life and determine how much it can be attributed to him. Evaluation is carried out on a 7-point scale. The proposed judgments meet either the criteria of sociopsychological adaptation of the individual (in particular - self-esteem and ability to respect others, openness to the real practice of activities and relationships, understanding of their problems and desire to master, cope with them, etc.). Either criteria of disadaptation, the presence of protective «barriers» in understanding their current experience, which seems to be a «solution» to problems, namely solving them on a subjective psychological level, in their own view, not in reality, the inflexibility of mental processes).

The method «Need for achievements» was developed by a group of scientists (Y. Orlov, V. Shkurkin, L. Orlova). The need for achievements is considered by the authors of the method as a person's desire to surpass the already achieved level of performance or realization, competition in this with himself or others. It manifests itself as a tendency to improve results, experience success in any (significant and insignificant) activities, the desire to finish work, under any circumstances. The need for achievement is positively related to the academic success of students.

The method «Test of meaningful life orientations» by D. Leontiev is an adapted version of the test «Purpose in life» (PIL). D. Crambo and L. Maholic developed PIL based on the theory of the desire for meaning and logotherapy by W. Frankl. The Russian version of the PIL test was adapted and turned into a test of meaningful life orientations by D. Leontiev. This test diagnoses the general indicator of meaningfulness of life, three variables that characterize the three components of meaningful life orientations («goal», «process»), «result») and two indicators locus of control (locus of control «I», locus of control «life»).

The method of «Self-actualization test» (SAT) was developed by a number of such scientists as Y. Alyoshin, L. Gozman, M. Zagika and M. Kroz. The basis of this technique is the questionnaire of personal orientations E. Shostrom (POI), which measures self-actualization as a multidimensional quantity. The self-actualization test is built on the same principle as POI, it measures self-actualization on two basic (scales of competence in time and support) and 12 additional scales that make six blocks - on two in everyone:

1) Scales of value orientations and flexibility of behavior represent «Block of values»;

2) «Block of feelings» are scales of sensitivity and spontaneity;

3) «Block of self-perception» are scales of self-esteem and self-acceptance;

4) «Block of awareness of the integrity of being» form a scale view of human nature and synergy;

5) «Block of interpersonal sensitivity» are scales of acceptance of aggression and contact;

6) «Block attitude to cognition» are the scales of cognitive needs and creativity.

Basic scales are aimed at measuring the global characteristics of self-actualization; additional scales are focused on the registration of its individual aspects.

A. Maklakov's personal questionnaire «Adaptability» in S. Chermyanin's adaptation allows estimating adaptive possibilities of the person through definition of a level of development of the psychological characteristics most important for 
regulation of mental activity and process of adaptation. As the main characteristics of the authors of the method identified the following: neuropsychological stability; communicative potential; moral norms. These characteristics allow its components and us to judge the level of development of personal adaptive potential (adaptability) in general (physiological, psychological and social) separately.

Methodology «Diagnosis of the implementation of needs for self-development» allows you to determine how actively a person realizes their needs for selfdevelopment: it has developed a system of self-development or it, on the contrary, is in the statistical stage.

Using the method of «Study of professional identity of students of the Faculty of Psychology» N. Antonova can diagnose the level of professional identity of future psychologists, the level of development of its main indicators (awareness, formation, acceptance) and components (motivational, cognitive, conative, affective), and determine the type professional identity in relation to the development of its indicators.

Statistical processing of results must be performed using the program «Statistica 6.0-8.0». In order to determine the statistical significance of the differences, we used Student's t-test. Pearson's correlation analysis was used to determine statistically significant relationships between variables. The indicators obtained in the study corresponded to the normal law of data distribution, which was verified by calculating the corresponding coefficients of asymmetry and excess, which for all studied indicators did not exceed the critical indicators corresponding to the normal distribution. 


\title{
PSYCHOLOGICAL CORRECTION OF AGGRESSIVENESS OF ADOLESCENTS WITH CHILDHOOD CEREBRAL PALSY
}

\author{
Panov Mykyta \\ Dr. in Psychology, Assistant Professor \\ Municipal Institution of Higher Education «Khortytsia National Educational \\ Rehabilitation Academy» of Zaporizhzhia Regional Council \\ Netrebenko Maryna \\ student of group SEM-1 (2) \\ specialty 016 Special education, \\ Municipal Institution of Higher Education «Khortytsia National Educational \\ Rehabilitation Academy» of Zaporizhzhia Regional Council
}

In today's conditions, the process of formation of the adolescent's personality depends on the influence of various positive and negative factors. Aggressive behavior in children and youth environment has a negative impact on the individual: complicates quality education, sports and work, distorts the psyche, disrupts social ties and reduces the overall intellectual and spiritual level. Each individual expression of an aggressive reaction due usually complex interaction of biological, physiological, psychological and social determinants.

Manifestation of aggression in children's educational institutions is a problem that worries parents and teachers, and is relevant to society.

Psychologists suggest that aggressive children difficult adjustment to life in society and is one of the first places in the deviant behavior of minors. Therefore, the task of the psychologist should be psycho-correctional work with adolescents, and especially adolescents with special educational needs who are more aggressive towards others.

At the beginning of the experimental study, the following tasks were set:

a) To identify the most common forms of aggressive behavior in students with cerebral palsy;

b) To investigate the level of aggression in this category of adolescents; behavior;

c) To identify possible factors affecting the level of aggression and aggressive

d) To develop a set of exercises and recommendations for teachers and educators of the special boarding school № 1 in order to reduce the level of aggression of adolescents diagnosed with cerebral palsy.

To meet these objectives, we have used the methods of questionnaires and interviews.

At the first stage of the work, a survey of respondents was conducted to identify adolescents with aggressive behavior. For this purpose, the questionnaire «Criteria for detecting an aggressive child», developed by E. Lyutova, was used. 
The questionnaire consists of eight statements that characterize adolescents' diagnosed with cerebral palsy behavior. It is suggested to note the frequency of each situation during the last five months. In processing the results takes into account the number of responses in the column «often». If four or more criteria appear frequently, it can be assumed that the student is aggressive.

In the second stage, the level of manifestation of various forms of aggressive behavior was determined, and the presence of characteristic types of reactions for adolescents with cerebral palsy was investigated.

Aggression has qualitative and quantitative characteristics. Like any property, it has varying degrees of severity. Excessive development of aggression begins to determine the whole feature that can become conflictual, incapable of conscious cooperation, etc.

The Bassa-Darka questionnaire was used to determine the indices of aggression and hostility. Evaluation of answers is carried out on eight scales that are corresponding to forms of aggression.

With the help of the first test the peculiarities of adolescents, the level of their aggression, its orientation and the nature of manifestation were specified.

The survey helped to determine family relationships, the role positions of each family member, the presence or absence of conflict in the family. The Devil's Dozencharacter accentuation test at the research stage was not intended to diagnose any mental illness. He allowed us to identify some striking features of the character of the subjects because several features already make up the personality. If a person has expressed one of the personality traits, brightly, noticeably - this is the so-called accentuation of character, or personality psychotype. With the help of this test, character traits are examined within the framework of the usual drawing of the personality and thirteen types of accentuations, namely pronounced psychotypes, are distinguished.

The study was conducted in the middle of the first semester in a secondary special boarding school №1 for adolescents with mental and physical disabilities (musculoskeletal disorders and the effects of polio). Students of classes of the mass curriculum (students with the norm of intellectual development) were selected. The total number of students is 46 people, nine adolescents live in a full family and fourteen adolescents have families, but during the school year for one reason or another live in a boarding school.

Teachers of these classes were asked to determine the frequency of certain behavior. It was suggested to note the frequency of each situation during the last five months. Based on the results of the questionnaire, adolescents who may be aggressive were identified. They were allocated to a separate group, with which further research was conducted.

The next step was to conduct a questionnaire Bass-Daria.

The group testing method was used during the Devil's Dozen test.

Based on a survey of boarding school teachers, students whose behavior can be considered aggressive were selected from the total number of adolescents in the class. This group includes 30 adolescents, which is $65 \%$ of the total, of which 17 boys and 13 girls. 
Quantitative indicators of different forms of aggression obtained in our study are given in the table.

Table 1

Manifestation of aggression and hostility in adolescents with cerebral palsy

\begin{tabular}{|c|c|c|c|c|c|c|}
\hline \multirow{2}{*}{ № } & \multirow{2}{*}{ Type of reaction } & \multicolumn{4}{|c|}{ Sex } & Total number, \\
\cline { 3 - 6 } & & boys & $\%$ & girls & $\%$ & $\%$ \\
\hline 1 & Verbal aggression & 17 & 57 & 5 & 17 & 74 \\
\hline 2 & Physical aggression & 13 & 43 & 4 & 13 & 56 \\
\hline 3 & Indirect aggression & 7 & 23 & 6 & 20 & 43 \\
\hline 4 & Hostility & 5 & 17 & 13 & 43 & 60 \\
\hline 5 & Suspiciousness & 6 & 20 & 4 & 13 & 33 \\
\hline
\end{tabular}

In general, we can say that adolescents diagnosed with cerebral palsy are characterized by verbal aggression; characterized by hostility to others, these adolescents often use physical and indirect aggression in everyday life.

Based on the test of character accentuations of adolescents with cerebral palsy, the hyperthymic-steroid type of character accentuations was determined - $14 \%$, in $10 \%$ the conformal-hyperthymic type was determined. Sensitive type was found in $13 \%$ of respondents. A paranoid variant of personal accentuation (paranoid type) was found in $60 \%$ of the respondents. It should be noted that the paranoid variant in child and adolescent psychology and psychiatry is not distinguished. However, previous clinical experience shows that with prolonged traumatic exposure, some adolescents with cerebral palsy have paranoid tendencies with overvalued relationship ideas.

This type of personality development is formed under the influence of prolonged influence of a set of traumatic factors, the main of which is the feeling of inferiority in combination with social or emotional deprivation under adverse microenvironment and education on the type of hypoprotection or emotional «oppression».

Based on the above, we can conclude that for adolescents diagnosed with cerebral palsy, studying in a boarding school, a characteristic type of aggression is verbal aggression. Physical aggression is less pronounced. For most respondents there is a feeling of inferiority, hostility to others. One of the important factors contributing to aggressive behavior is unfavorable family conditions. Almost every adolescent is in such conditions and feels depressed, insecure. For many adolescents, the existence of a sense of family relationship is unrealistic. In many cases, students feel inferior in the family, are in conflict with other family members. Thus, aggressive behavior is a protective mechanism. This is because adolescents live permanently in a boarding school and try to adapt to living conditions and the environment, but the work on correction should be carried out in contact with family, with a psychologist. The BassaDarki questionnaire is an assistant in working with aggressive adolescents, which helps to identify types of aggression and plan further work.

Summarizing all the above, we note that diagnosing the causes of aggression and finding effective ways to reduce its level is not easy. This job requires the ability to work with family, a psychologist, knowledge and professionalism.

However, the most important thing that people who work with behavioral aggression need to know is hope. There is no convincing scientific evidence that 
aggression is unavoidable. However, there are many opposites - that aggressive behavior can be prevented or, in extreme cases, reduce the frequency of its manifestations. Values opposed to aggression and violence can be a powerful tool to stop them.

Helping a adolescents with behavioral aggression is unthinkable without working with parents. Nevertheless, the requirements must be agreed. Sometimes parents lack responsibility, sometimes - psychological culture, sometimes - the desire to change something. 


\section{РОЛЬ ІГРОВИХ ТЕХНОЛОГІЙ У ПРОФІЛАКТИКИ НЕГАТИВНИХ ЕМОЦІЙНИХ СТАНІВ ДОШКІЛЬНЯТ}

\section{Пономарьова Валентина Леонідівна}

викладач

Ізмаїльський державний гуманітарний університет

\section{Захарченко Вікторія В'ячеславівна}

студентка

Ізмаїльський державний гуманітарний університет

Поняття «емоційна сфера особистості» включає в себе емоції, почуття, переживання, настрої, інтереси, мотиви, установки. Говорячи про емоційну сферу, можна вийти з того, що вона властива кожній людині.

Важливість вивчення проблеми пояснюється тим, що емоції стають безпосередньою причиною невротичних станів дитини і надалі визначають дорослі проблеми. Емоційну реакцію дитини викликають чинники, пов'язані із задоволенням його актуальних потреб, а несвоєчасне задоволення потреб для розвитку певних функцій накладає відбиток на все подальше життя людини i призводить до виникнення емоційних порушень.

Прояв i переживання емоцій i почуттів залежить від індивідуальної специфіки емоційної сфери особистості, обумовленої природними передумовами. Перевага індивідом тих чи інших соціальних емоцій відображає накопичений їм позитивний і негативний життєвий досвід і може служити критерієм особистісного розвитку.

Страх, тривожність, агресія є типовими психічними емоційними станами дітей дошкільного віку, як показало дослідження Прохорова А.О. і Велієв. C.В. На їх частку припадає $36 \%$ від загального числа емоційних станів, характерних для дітей дошкільного віку. Причому агресія і страх обумовлена самою програмою розвитку дитини, де дані стану $\epsilon$ «охоронним ланкою поведінкового онтогенезу» [8, с 47]. Страх, тривожність, агресивність - емоції, які виникають в умовах загрози біологічному або соціальному існуванню суб'єкта і спрямовані на причину як реальної, чи уявлюваною небезпекою.

При сприятливих умовах розвитку у дитини виникають позитивні емоційні стани, які закріплюються і перетворюються в відповідне риси характеру життерадісність, допитливість, чуйність та ін.

У науковій літературі вказується, що виникнення і фіксації у дітей різних негативних емоційних станів, таких як страх, тривожність, агресивність сприяють сучасна соціально-інформаційної середовище, в якому протікає розвиток дитини-дошкільника, а саме: дефіцит спілкування з батьками, 
обмеження i спрощення ігрових форм освоєння дійсності, надмірність неадекватною віковим особливостям дітей інформації і ін. [7, с.23].

Фіксація негативних емоційних станів у дошкільнят може привести до виникнення досить серйозних проблем в їх поведінці і розвитку в цілому: змінюється мислення, виникає стан емоційної напруженості, спотворюється емоційно-вольова сфера, неадекватно сприймаються людьми. На думку фахівців, які працюють з дошкільнятами, які мають порушення в емоційному розвитку, «немає жодної психічної функції, яка не могла б зазнати несприятливих змін» [4, с. 7].

Одним з найбільш ефективних засобів профілактики виникнення негативних емоційних станів у дошкільнят є ігрові технології.

Ігрові технології - ці систематизовані набори ігор, вправ, завдань ігрового характеру, які будуть спрямовані на реалізацію завдань розвитку у дітей тих чи інших значущих соціально-культурних функцій або корекції їх недоліків.

Для організації профілактичної роботи з дошкільнятами фахівцями широко застосовуються такі ігрові технології, як ігротерапія, казкотерапія, музикотерапія, ізотерапія і їх елементи, а також психогімнастика, релаксаційні вправи та ін. В процесі використання даних ігрових технологій відбувається формування особистості дитини-дошкільника, підготовка ii до різних видів діяльності. Ігрові технології розвивають психологічну пластичність, вміння прийняти на себе роль, позицію і щиро відстоювати ії. Вони дозволяють дитині бути особисто причетним до процесів, що протікають в суспільному житті, дають можливість «прожити» деякий час в «реальних» життєвих умовах, дозволяють дошкільнятам здійснити масу соціальних проб, прийняти на себе різні соціальні ролі, дозволяють побачити результати власних дій, зрозуміти i проаналізувати допущені помилки, в тому числі і ті, які були зроблені іншими учасниками ігрового взаємодії. Розглянемо їх більш детально.

Психогимнастика - це курс спеціальних занять (етюдів, вправ та ігор), спрямованих на профілактику, розвиток і корекцію різних сторін психіки дитини (як пізнавальної, так і емоційно-особистісної сфери), а також на розвиток довільності поведінки.

Довільність у вітчизняній науці, слідом за Виготським Л.С. розуміється як здатність володіти собою, своєю зовнішньою і внутрішньою діяльністю [2, с 14]. Розвиток довільності полягає в оволодінні засобами, що дозволяють усвідомити свою поведінку і керувати ним [11, с.61].

В основі психогимнастических вправ лежать уявлення про механізми психофізіологічної саморегуляції людини, законах їх формування в онтогенезі, їх взаємообумовленості і внутрішніх зв'язках. Основні механізми психічної регуляції людини проявляються у функціональному психофізіологічному єдності діяльності організму як цілісної системи. Ця єдність означає, що зміна в діяльності будь-якого елементу системи викликає зміни в роботі інших його 
ланок. Розуміючи, як працює цей механізм, можна свідомо впливати на діяльність менш довільних психічних функцій, використовуючи ті, які підвладні вольовому контролю.

Довільна саморегуляція у людини здійснюється на рівні слів, понять, вольових зусиль, внутрішніх планів, уявлень кінцевих результатів своїх дій умовних заступників справжніх відчуттів або образів.

У дитини можливість керувати своєю поведінкою з'являється тільки в міру дозрівання мозкових структур і певних нервових механізмів. Дорослий може сприяти цьому процесу, створюючи умови для діяльності i тренування зростаючих і дозріваючих функцій організму. Здатність регулювати різні сфери життя - рухової, емоційної поведінкової, комунікативної складається 3 конкретних контролюючих умінь в цих сферах.

У руховій сфері такими є вміння довільно направляти свою увагу на м'язи, які беруть участь в русі; вміння розрізняти і порівнювати м'язові відчуття; вміння визначати відповідний характер відчуттів (напруга - розслаблення, тяжкість легкість і т. д.), характер рухів, супроводжуваний цими відчуттями (сила слабкість, різкість -плавність, темп, ритм).

В емоційній сфері - вміння довільно направляти свою увагу на пережиті емоційні відчуття; вміння розрізняти і порівнювати емоційні відчуття, визначати їх характер (приємно, неприємно, неспокійно, дивно, страшно і т. д.); вміння одночасно направляти свою увагу на м'язові відчуття і на експресивні руху, які супроводжують будь-які власні емоції, які відчувають оточуючі; вміння довільно «відтворювати» або демонструвати емоції по заданому зразку. [10, c.19].

У сфері спілкування - вміння вловлювати, розуміти i розрізняти чужі емоційні стани; співпереживати ( приймати позицію партнера по спілкуванню i повноцінно проживати, відчути його емоційний стан); вміння відповідати адекватними почуттями (у відповідь на емоційний стан товариша проявити такі почуття, які принесуть задоволення учасникам спілкування).

У поведінкової сфері - вміння визначати конкретні цілі своїх вчинків; вміння шукати i знаходити, вибираючи 3 безлічі варіантів засоби досягнення цих цілей; вміння перевіряти ефективність обраних шляхів діями, помиляючись i виправляючи помилки, досвідом почуттів або минулих аналогічних ситуацій; вміння передбачати кінцевий результат своїх дій і вчинків; вміння брати на себе відповідальність.

Музикотерапія. Поєднання музикотерапії з іншими техніками є корисним i ефективним для профілактики негативних емоційних станів по ряду причин. Поперше, використання музики сприяє усвідомленню дитиною своїх почуттів, допомагає навчити дитину розуміти, наскільки різноманітними можуть бути людські почуття. «Музика певного характеру робить зміст почуття більш зрозумілим для дитини і стимулює його до вербальним оцінками емоційного 
переживання». Музика емоційна за своєю сутністю, i тому се сприйняття $\epsilon$ емоційним пізнанням, дає прекрасну можливість розвитку емоційної сфери людини, особливо в дитинстві, найбільш сприйнятливому з будь-якого віку.

Запорожець А.В. (1986) також зазначав, що емоції починають регулювати динамічну сторону поведінки дитини вже на ранніх стадіях його розвитку. Поступово складається своєрідна функціональна система, в якій органічно поєднуються особливі пізнавальні процеси. «Розвиваючись в цій системі, емоції стають узагальненими, що передбачають, а процеси пізнавальні, функціонуючи в даній системі, набувають афективний характер» [3, с. 50].

Використання музичних технік дозволяє дитині освоїти більш ефективні способи вираження своїх емоцій. Дитина отримує можливість висловити свій гнів i роздратування через звук, так як звукова експресія $\epsilon$ досить ефективною. Крім того, витяг звуку може стати і способом безпосереднього вираження почуття гніву, яким дитина може користуватися і поза заняття.

Сучасні діти часто бувають напружені фізично і емоційно, що призводить у них до прояву роздратування і раціональної поведінки. Тому важливо навчити дитину швидко розслаблятися. Це процес $є$ більш успішним, якщо навчання релаксації проводиться на тлі звучала музики: «спеціально підібрана музика, допомагає дитині зосередитися на створюваних ним образах, відчути м'язове розслаблення»[1, с. 44].

Казкотерапія у вітчизняній науці визначається як «цілеспрямоване використання казок в психокорекції та терапевтичної роботі» [6, с.203]. Цей метод дозволяє використовувати казкову форму для інтеграції особистості, розвитку творчих здібностей, розширення свідомості, вдосконалення взаємодії 3 навколишнім світом. В його основі лежить ідея про те, що кожна казкова ситуація несе в собі величезний прихований сенс, досвід вирішення нашими предками складних життєвих проблем.

Тексти казок викликають інтенсивний емоційний резонанс як у дітей, так і у дорослих. Образи казок звертаються одночасно до двох психічним рівнями: до рівня свідомості і підсвідомості, що дає особливі можливості при комунікації. Особливо це важливо для корекційної роботи, коли необхідно в складній емоційній обстановці створювати ефективну ситуацію спілкування.

Принципи казкотерапії полягають в знайомстві дитини зі своїми сильними сторонами, в «розширенні» його поля свідомості і поведінки, в пошуку нестандартних, оптимальних виходів 3 різних ситуацій, обміні позитивним життєвим досвідом. Цей метод розвиває творчі здібності і вміння слухати інших, вчить приймати і створювати нове [12, с.64].

Малювання - творчий акт, що дозволяє дитині відчути і зрозуміти самого себе, висловити вільно свої думки і почуття, звільнитися від конфліктів і сильних переживань, розвинути емпатію, бути самим собою, вільно висловлювати мрії. 
Процес малювання надає розвиваюче вплив і володіє незаперечними перевагами, в порівнянні з іншими видами дитячої діяльності, а саме: розвиває чуттєво-рухову координацію.

Малюючи, дитина дає вихід своїм почуттям, бажанням, мріям, перебудовує свої відносини в різних ситуаціях і безболісно стикається з деякими страшними, неприємними, травмуючими образами. Таким чином, малювання виступає як спосіб осягнення своїх можливостей і навколишньої дійсності, як спосіб моделювання взаємовідносин і вирази різного роду емоцій, в тому числі i негативних. Тому малювання широко використовують для зняття психічної напруги, стресових станів при корекції неврозів, страхів [9, с 56].

При використанні малюнкових технік виходять 3 того, що: різні техніки малювання це самовираження в малюнку і моделювання конфліктної ситуації; в образотворчій діяльності якість малюнка не виступає важливим критерієм його оцінки (рисунок володіє власною цінністю, пов'язаної з послідовністю етапів дозволу особистісних проблем дитини); в процесі малювання педагог допомагає дітям усвідомити і розв'язати проблемну ситуацію, зовні ії висловити в малюнку (ліплення) і визначити вихід з неї [5, с. 33].

Сюжетно-рольова гра передбачає прийняття дитиною на себе ролі образу. Під роллю розуміється якась функція, виконувана дитиною в тій чи іншій ситуації. Дитиною можуть прийматися ролі різні за змістом і статусу, дошкільник також може програвати ролі протилежні його характеру .

Психодіагностична гри дозволяють педагогу виявити деякі особливості дитини, а також оптимізувати ставлення до свого імені, своїми особистими якостями, емоційно-ціннісному відношенню до себе, підвищити самооцінку.

Комунікативні ігри сприяють поглибленню сфери спілкування і навчають вмінню співпрацювати дошкільнят з оточуючими людьми.

Реалізації даних ігрових технологій буде найбільш ефективною при організації соціально-культурного середовища, в якій протікає розвиток дитинидошкільника, адекватної його віковим можливостям, а також при створенні діалогової основи взаємовідносин дошкільнят 3 дорослими і однолітками як аспекту особистісного становлення дитини-дошкільника, забезпеченні готовності учасників педагогічного процесу до діяльності по профілактиці

Негативних емоційних станів у дітей, яка передбачає проведення навчальної методичної роботи 3 педагогами, які працюють 3 дошкільнятами, реалізацію педагогічної програми, навчання педагогів і батьків методам i прийомам, спрямованим на розвиток емоційно-особистісної та комунікативної сфер дошкільнят, організацію ігрової діяльності з дітьми, що допоможе уникнути грубих помилок і домогтися цілісного формує ефекту в процесі педагогічної діяльності.

Отже, можемо сказати, що розглянувши причини виникнення негативних емоційних станів у дошкільнят, було обгрунтовано застосування ігрових 
технологій для їх профілактики. Також описано застосування таких технік, як: психогімнастика, музикотерапія, казкотерапія, проективний малюнок, сюжетнорольова гра, вербальні, психодіагностичні, комунікативні ігри. Були зроблені висновки, що використання ігрових технологій $є$ оптимальним засобом, що дозволяє всебічно і опосередковано впливати на процес формування емоційної сфери дошкільника і сприяє профілактиці негативних емоційних станів дошкільників.

\section{Список літератури}

1. Ворожцова О. А. Музика і гра в дитячій психотерапії. М., 2004. С. 62.

2. Виготський Л. С. Педагогічна психологія / За ред. В. В. Давидова. М., 1991.

3. Запорожець А. В. Вибрані психологічні праці: в 2 Т. М., 1986. Г 1. С. 52.

4. Захаров А. І. Як допомогти нашим дітям позбутися страху. Ужгород , 1995. C. 10 .

5. Карабанова О. А. Гра в корекції психічного розвитку дитини. М., 1997.

6. Оклендер В. Вікна в світ дитини. М., 2000. С. 211.

7. Орлов А. Б., Орлова Л. В., Орлова Н. А. Психологічні механізми виникнення і корекції нав'язаних дитячих страхів // Питання психології. 2011. № 3. C. $17-31$.

8. Осипенко Т. Н. Психоневрологічне розвиток дошкільнят. М., 1996. С. 157.

9. Осипова А. А. Загальна психокорекція: навч. посібник для студентів вузів. М., 2001..

10. Прохоров А. О., Велиева С. В. Психічні стану дітей дошкільного віку // Питання психології. 2003. № 5. С. 56-67.

11. Смирнова Є. О., Холмогорова В. М. Міжособистісні відносини дошкільнят: діагностика, проблеми, корекція. М., 2005. С. 132.

12. Яковлєва М. В. Казкотерапія і символдрама // Школа здоров'я. 1999. № 3. C. 61-67. 


\section{ДИНАМІКА ВЗАСМИН В БАТЬКІВСЬКО-ДИТЯЧІЙ ПІДСИСТЕМІ ЯК ІНДИКАТОР ПСИХОЛОГІЧНОЇ БЕЗПЕКИ В СІМ'ї}

\section{Примак Юлія Володимирівна} кандидат психологічних наук, доцент, доцент кафедри загальної, вікової та соціальної психології Національний університет "Чернігівський колегіум" імені Т.Г. Шевченка

Потреба у безпеці - одна з базових. Без її задоволення людині було б складно (навіть неможливо) самореалізуватися (особливо у сучасному світі). Безпека особистості в середовищі (сім'ї) - феномен, що увиразнює необхідну умову розвитку будь-якої системи, якою є й особистість, і сім'я (забезпечуючи їхню надійність, захищеність, холістичність, стабільність, супротив, життєстійкість). Відмітимо, що безпека найчастіше розглядається, на часі, як відсутність небезпеки і постійного негативного впливу (Н. Слободських, D. Fisher), загроз (В. Бирюков, Ю. Рождественський), властивість/атрибут системи (В. Молчановський), специфічна діяльність, спрямована на нейтралізацію реальних і потенційних загроз (В. Леоничева, П. Тимохін).

Хоча структура сім'ї дуже й еволюціонувала, роль дорослих членів сім'ї (як правило, батьків) у забезпеченні психологічної безпеки лишається непропорційно вищою, ніж в інших членів. Зв'язок і зворотній зв'язок соціального середовища (йдеться про сім'ю) і людини (дитини) значущий для становлення останньої як успішної особистості. Здатність людини адаптуватися до середовища, вступаючи у психологічно безпечні відносини, сприяє гармонійному формуванню, розвитку іiі особистості. Тому критерієм безпеки в батьківській сім'ї $є$ міра гармонійності - дисгармонійності стосунків (подружніх, батьківсько-дитячих, сиблінгових). У цьому разі система безпеки особистості опосередковується сім'єю (в якості соціальної основи), що з одного боку посилює першу, а з другого - послаблює.

Затребуваність і злободенність обраної проблеми у сучасній науковій психології, особливо в реальному житті людини, обумовила й обгрунтувала необхідність дослідження динаміки психологічної безпеки особистості в сім'ї, зокрема на рівні батьківсько-дитячої підсистеми. Вибірку досліджуваних склали студенти психолого-педагогічного факультету, факультету фізичного виховання Національного університету «Чернігівський колегіум» імені Т.Г. Шевченка та учні 10-11-х класів Чернігівської загальноосвітньої школи I-III ступенів № 6 $(\mathrm{n}=260$ осіб, $33 \%$ - особи чоловічої, $67 \%$ - жіночої статі; 65\% - респонденти 3 повної, а 35\% - неповної сім'ї). За методи дослідження правили авторська анкета й незакінчені речення. Результати дослідження засвідчили наступне.

Мати, як виявилося у вибірці юнок, найчастіше демонструє до своєї дитини емоції радості (у 73\% випадках) та тривогу (55\%), а також інтерес (8\%), гнів (5\%). Водночас, не перевищуючи 3\% бар'єр, дівчатами згадувалися горе-страждання, сором, подив, провина, презирство і зніяковілість. Респонденти чоловічої статі 
продемонстрували схожі результати (радість - 74\% і тривога - 44\%), а от значущо третьою у їхніх стосунках $з$ матерями увиразнилася емоція інтересу (38\%). Тривідсотковий бар'єр не подолали аналогічні, вищезгадані емоції. Звернімо увагу, що сама мати у 43,8\% випадках забороняла виражати досліджуваним «дітям» емоції негативного характеру, а у 54\% - реагувала спокійно (у 3\% - взагалі заохочувала). Заразом респонденти чоловічої статі таку заборону відзначили аж у 91\% випадках, а заохочення - 9\%. На сучасному етапі, на думку молоді, це змінилося насамперед у хлопців (52\%), а не значущо у дівчат (13\%). Нічого радикального у материнсько-дитячих стосунках не відбулося в житті більшої половини молодих людей (58\%: 3 них 54\% - у дівчат, 71\% хлопців). Зустрічалися й такі поодинокі виразні відповіді, на кшталт: «змирилися», «почали вільно спілкуватися на різні теми», «стосунки стали толерантнішими», «досягнуто компромісу», «стало нейтрально».

Батько, за свідченнями, у 46\% забороняв виражати негативні емоції респондентам, коли ті були дітьми, у 53\% ставився спокійно, нейтрально, а їх заохочував - лише у $2 \%$ випадках. Саме тоді у респондентів чоловічої статі ця заборона зафіксована у 81\% порівняно з 38\% респондентів жіночої. У 5\% у перших навіть заохочували (порівняно 3 1\% у других). Третина молоді зауважила, що сьогодні в їхніх стосунках з батьком щодо прояву нею емоцій негативного спрямування нічого не змінилося (33\%).

Отож, матір у стосунках 3 сином постає як постать, через яку більше відбувається наслідування емоційної та когнітивної складових у формуванні психологічної безпеки. Водночас і матір, і батько вимогливіші, категоричніші до вираження негативних емоцій сином, ніж донькою. Розвиток здатності до емоційної регуляції в сім'ї відбувається через засвоєння дитиною переконань батьків щодо емоцій (дві крайнощі: відкрите заохочення або батьківська заборона на вираження саме негативних), а також формування уявлень про те, як керують ними самі батьки. Найефективнішим для розвитку дитини є нейтральне, спокійне ставлення батьків до вираження негативних емоцій дитиною без цілеспрямованого заохочення. Як бачимо, половина батьків обох статей свідомо чи несвідомо, але дотримується цього «правила» емоційної взаємодії з дітьми.

Зрозуміло, що, аналізуючи отримані результати, важливо відмітити вік респондентів (середній - 19 років). Юнацтво - період активної рефлексії, спрямованої на розвиток істинної відкритості, близькості в міжособистісних контактах (хоча водночас усвідомлення власної унікальності поєднується 3 відчуттям самотності у цьому віці), прийняття особистістю самої себе. І в цьому значущу роль відіграє і батьківська сім'я, оскільки юнаки й юнки у цілому налагодили емоційні контакти 3 батьками i на свідомому рівні (йдеться, наприклад, про необхідність наслідувати їхній життєвий досвід, а в окремих випадках і значущий дорослий може виступати ідеалом). Нами підтверджено, що у складних ситуаціях і хлопці, і дівчата насамперед звертаються за порадою до матері, а потім - саме хлопці - до батька (стосунки зі значущим дорослим стають більш довірчими). Також для повноти картини досліджуваного феномена бажано попрацювати з батьками, іншими членами сім'ї респондентів. Заразом навіть і такі результати дозволяють сформувати уявлення про особливості динаміки 
психологічної безпеки в сучасній сім'ї, грунтуючись на описі «дітьми» сімейних стосунків (передусім батьківсько-дитячих і подружніх).

Повертаючись до результатів, відмічаємо, що в емоційному компоненті психологічної безпеки все ж переважає позитивний полюс, хоча й резонування «тривоги» не дозволяє засвідчити виключно стабільний характер явища, що досліджується. Складові психологічної безпеки сімейного середовища у третини респондентів чоловічої статі і більш ніж половини жіночої засвідчили свою надійність, що апріорі можемо розглядати як ознаку успішного розвитку особистості дитини в ньому, формування адаптивної здатності до самозбереження.

Чуйною особою у батьківській сім'ї, що і не дивно, є насамперед матір (86\%) - у хлопців і дівчат цей результат значущо не різниться (зрозуміло, що незалежно від статі дитини частіше трансгенерується досвід саме матері, ніж батька). Батька таким уважає 52\% респондентів (при цьому у хлопців він постає чуйним значущо частіше $(\mathrm{p} \leq 0,05))$. Самих себе емпатійними назвали насамперед дівчата $(48 \%)$ порівняно 3 хлопцями (29\%) (при тому, що емоційна сенситивність сприйнятливість - цілком властива юнацькому віку).

Насторожує той факт, що третина молодих людей (35\%; при чому, i хлопці, i дівчата майже в однаковій мірі) часто ставали свідками конфліктів між батьками, $47 \%$ - їх пам'ятають як «іноді були», а таких, що «взагалі не пригадують» -23\% (відсоток осіб чоловічої статі зафіксовано на порядок вищий: 43\% проти 18\%). Тому апріорі психологічна безпека у третини молоді потрапляє під сумнів щодо iii можливостей у реалізації відчуття надійної й стабільної захищеності особистості.

Позаяк у цілому безпека сімейного середовища та його учасників увирзнюється у задоволенні основних базових потреб, то і це було враховано у дослідженні. Так, у батьківській сім'ї найкраще задовольняються такі потреби (наводяться у порядку спадання): потреба бути прийнятим, потреба в любові, потреба в теплих стосунках; потреба у захищеності від приниження; потреба у стабільності, передбачуваності, упевненості у майбутньому; потреба у захищеності від ігнорування; а от найменше - потреба у захисті від образ i примусу. Така ієрархія у задоволенні потреб була у більшості респондентів завжди (65\%), а у третини - не завжди (35\%). Трансгенерації в сім'ї характеризуються комплексом закономірних тенденцій: ті батьківські і подружні настанови, що відтворюються, можуть спрямовуватися як на зближення, так і на віддалення членів сім'ї одне від одного. Водночас захищеність від образ i примусу - потреба, що найгірше задовольняється в сім'ї, в яких виховувалися саме дівчата. Відмітимо також те, що найкраще задоволена потреба «дитини» у можливості звернутися за допомогою у батьківській сім'ї (iз 5 балів - на 4,2). I задоволені, і незадоволені респонденти: стосунками з матір'ю, батьком (заразом все ж більш задоволені респонденти чоловічої статі), стосунками з сиблінгами, за їхньої наявності (теж більш задоволені хлопці), можливістю виразити свою позицію/точку зору в батьківській сім'ї, ставленням у ній.

Аби людина безпечно себе почувала в сім'ї, на думку молоді, потрібно, щоб в ній панували такі цінності: «довіра» $i$ «любов» (40\%), «повага» (39\%), 
«взаєморозуміння» (33\%), «підтримка» (30\%), «щирість, чесність» (26\%), «фінансова стабільність» (15\%), «гармонія» $i$ «аби вчасно вислухали» (13\%), «вірність», «відкритість», «прийняття у будь-якому стані», «урахування бажань одне одного» (по 6\% відповідно). Значущо-показовими і змістовними (десь і жартівливими, а водночас і злободенними), але поодинокими, були й такі описи респондентами умов відчуття психологічної безпеки, комфорту у сім'ї, як: «щоб батьки кохали одне одного», «діти були щасливими», «там, де не зловживають алкоголем», «там, де готові віддати все за сім'ю», «де повний холодильник», «де вміють розуміти й підтримати», «де відсутній авторитаризм і злість», «де забезпечують».

Отже, феномен психологічної безпеки найкраще розкривається за такими складовими, як: емоційний компонент (кохання, ніжність у стосунках, радість, інтерес, тривога, чутливість); когнітивний компонент (почуття гумору, взаєморозуміння, довіра, рефлексія); конативно-поведінкова (адекватна соціалізація інстинктів, потреб і мотивів, задоволення потреб людини соціально прийнятним способом). Особливе місце у досліджуваному феномені зайняли матеріальна складова (фінансова стабільність, матеріальний достаток, наявність власного житла, забезпеченість) і моральна (віра в Бога, подружня вірність, дотримання сімейних традицій). Ці компоненти психологічної безпеки в батьківській сім'ї (передусім коли йдеться про емоційний і когнітивний) постійно динамізують досліджуваний феномен, вибудовуючи його певну ієрархію. Значущим виявилося почуття тривоги, яку, в переважній більшості, молоді люди успішно долають, транслюючи оптимістичне ставлення до життя у цілому (зокрема і до себе, i сім'í), чим увиразнюють і конативну складову у психологічній безпеці.

Здебільшого молодь - діти батьківських сімей - відкрито, продуктивно і гармонійно рефлексує 3 приводу проблем психологічної безпеки як на індивідуально-особистісному, так і середовищно-сімейному рівнях. Достатньо (третина) й таких, які цього не роблять в силу або банального небажання, або реального захисту від загрозливих переживань, джерела яких походять саме 3 сім'ї. Ці номінативні модуси психологічної безпеки особистості (дитини насамперед) в батьківській сім'ї постають як невротичні, дезадаптивні. У цьому разі батькам важливо насамперед мінімізувати вплив таких чинників, як: поперше, сімейні конфлікти у присутності дітей із застосуванням фізичної сили; по-друге, залякування, чим провокується виникнення страхів, тривожності, втрата довіри; по-третє, жорстоке ставлення дорослих до дитини. Для забезпечення психологічної безпеки дитини дорослим важливо також дуже уважно ставитися до власної поведінки з дітьми в їхній присутності, прагнути до довірчих стосунків 3 ними незалежно від їхнього віку. Покарання, якщо воно дійсно обгрунтоване, має відповідати віку, не має включати фізичного насилля або іншим чином принижувати самоповагу дитини. Дитину батьки повинні любити дещо більше, ніж себе. Саме психологічно здорова (безпечна) батьківська любов стає значущим і провідним чинником очевидної та надійної психологічної безпеки дитини. Здорова батьківська любов найкраще розкривається в: розумному дозуванні психічних, емоційних $\mathrm{i}$ фізичних 
навантажень (в т. ч. за рахунок організації режимних моментів); спостереженні за самопочуттям і настроєм дитини, виявленні причин неблагополуччя, організації своєчасної допомоги; наданні дитині максимально можливої для іiі віку самостійності і свободи; профілактиці порушень психоемоційних станів дітей; створення предметно-розвивального простору вдома і в освітніх закладах.

Обнадіює, що психологічна безпека у сучасній сім'ї - реальне явище. Психологічна безпека дітей і молоді у сучасній батьківській сім'ї в динаміці демонструє свій переважно оптимістичний характер. Так, досліджуваний феномен увиразнюється в трансляції особистістю дитини, молодою людиною сценаріїв подвійного позитиву (відносно повного) або подвійного негативу, опосередкованими передусім впливом постаті матері й батька (стосунками між ними, а також стосунками 3 дітьми). Другий сценарій можна попереджати або коригувати завдяки певному психологічному втручанню. 


\title{
ОСОБЕННОСТИ ЭКСПЛУАТАЦИИ КРУПНЫХ НЕФТЯНЫХ И ГАЗОВЫХ ПРОМЫСЛОВ УЗБЕКИСТАНА
}

\author{
Жумабоева Мастура Баходир кизи, \\ студентка, \\ Российский университет Дружбы Народов (РУДН)
}

\section{Бояркина Ольга Владимировна,}

студентка, Российский университет Дружбы Народов (РУДН)

\begin{abstract}
Аннотация. Дан анализ состояния нефтегазовой отрасли Республики Узбекистана. Показаны достижения и задачи в газодобывающих и нефтеперерабатывающих отраслях страны, сделан соответствующие выводы

Ключевые слова: Нефтегазовая промышленность Республика Узбекистан, экономическое положение, добыча нефти и газа, нефтегазопереработка.
\end{abstract}

\section{Features of operation of large oil and gas fields of Uzbekistan}

Abstract. An analysis of the state of the oil and gas industry of the Republic of Uzbekistan is given. Achievements and tasks in the gas and oil refining industries of the country are shown, the corresponding conclusions are made

Keywords: Oil and gas industry Republic of Uzbekistan, economic situation, oil and gas production, oil and gas refining.

Нефтегазовая отрасль Узбекистана является крупнейшим сегментом экономики и имеет важнейшее стратегическое значение для развития всей экономики республики. Несмотря на то, что на мировом рынке энергоносителей наблюдается нестабильность, отражающаяся и на состоянии нефтегазовой отрасли республики, деятельность нефтегазовых компаний вполне предсказуема. Вместе с тем ухудшение геологических условий добычи и рост издержек добываемых энергетических и минеральных ресурсов усиливают риски торможения роста промышленности, снижения экспортных поступлений [1, с. 4]. Накопленные проблемы отрасли за последние годы обернулись падением объёмов добычи нефти и природного газа. Для разработки соответствующих мер по решению стоящих перед отраслью проблем необходимо провести тщательные и объективные научные исследования.

Нефтегазовая отрасль занимает первое место в республике по объемам экспортной выручки и составляет 7 \% от общего объема ВВП [2]. Геологические запасы нефти республики составляют 5 млрд т, а доказанные запасы нефти - 530 
млн т. По итогам 2017 и 2018 гг. подтвержденные запасы нефти в Узбекистане составили 0,1 млрд т (0,6 млрд баррелей), а природного газа $-1,1$ трлн кубометров [3, с. 14]. По добыче газа республика занимает второе место в СНГ, а по добыче нефти на декабрь 2020 г. занимал 47-е место в мире [4]. Запасы газового конденсата сосредоточены в основном в Бухара-Хивинском и Сурхандарьинском районах республики [5, с. 25].

В целом деятельность нефтегазовой отрасли и удельный вес продукции топливной промышленности в структуре промышленного производства за последние годы характеризуется разнонаправленными трендами, рост в 20122017 гг. сменился падением с 2018 по 2019 г. (рис. 1). Анализ основных показателей топливной промышленности за 2002-2019 гг. показывает рост объёма продукции за последние 13 лет в 16,7 раза.

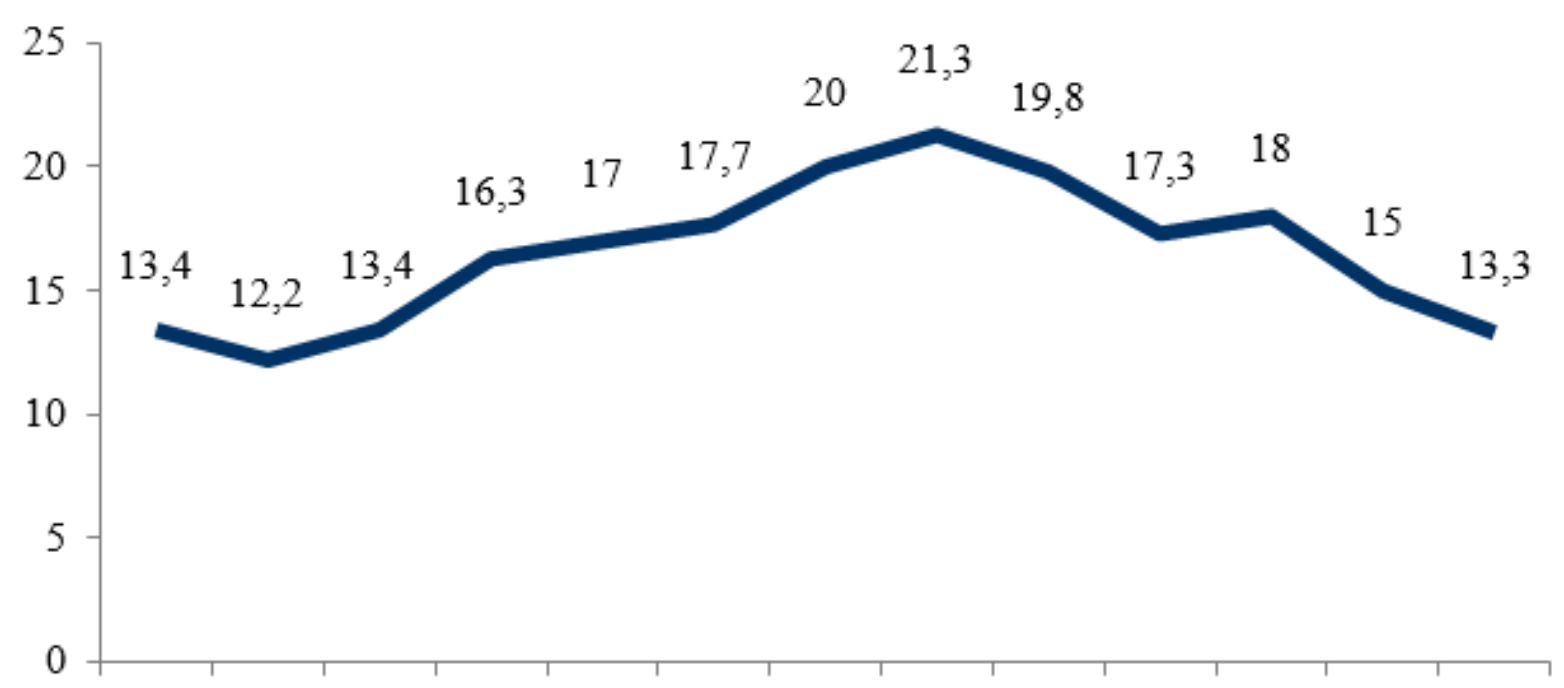

2007200620082009201020112012201320142016201720182019

Рис. 1. Удельный вес продукции топливной промышленности в структуре промышленного производства (\%)

В 2017 г. в нефтегазовой отрасли произведено продукции на сумму свыше 7,3 трлн сум (свыше 4,0 млрд долл. США) [6] и доля импорта составила 3,7 \%. За год было произведено 1,31 млн т бензина, 1,05 млн т дизельного топлива, 0,33 млн т керосина, 0,26 млн т СУГ и 0,26 млн т масел и смазок [7]. За 2019 г. добыча нефти и газового конденсата в Узбекистане снизилась на 10,8 \% по сравнению с 2018 г. В 2019 г. темпы роста выпуска промышленной продукции в сопоставительных ценах составили $102,6 \%$ [8].

В 2018 г. планировалось снизить себестоимость продукции на 291,3 млрд сум, а фактически этот показатель достиг 294,6 млрд сум и выполнен на 101,1 \%. В 2019 г. темпы роста производства промышленной продукции относительно аналогичного периода 2018 г. составили 101,6 \% [9]. В целом добыча нефти за 2002-2019 гг. снизилась в 2,5 раза.

Добыча газа с 1991 по 2013 г. выросла с 41,9 до 68,3 млрд куб. м, а с 2014 по 2019 г. снизилась до 54,2 млрд куб. м или на 21 \% последние 6 лет. 
Наряду с позитивными результатами деятельности нефтегазовой отрасли в последние годы возникли проблемы и негативные тенденции, связанные объективными и субъективными причинами, а их следствием стало снижение объемов добычи нефти и газового конденсата, а также природного газа.

Объемы добычи нефти в республике стали снижаться начиная с 2002 г., в то время как потребление только росло. В течение 90-х гг. 20 века производство нефти резко увеличилось с 2,8 млн т в 1991 г. до 8,1 млн т к 2002 г., но в последующем объемы добычи нефти неуклонно снижались, и если в 2003 г. ежедневный объём добычи нефти составлял 171 тыс. баррелей, то в 2014 г. - 107 тыс. баррелей, а в декабре 2019 г. достиг 65 тыс. баррелей. Как считают эксперты, к объективным причинам устойчивого падения добычи нефти и газового конденсата можно отнести истощение запасов действующих месторождений, причем текущий объем извлекаемых резервов жидких углеводородов не превышает 0,1 млрд т (коэффициент резервов к текущей добыче - 18,9). Кроме того, причиной также считается ограниченность сырьевой базы и неудачная эксплуатация имеющихся запасов в первые годы независимости.

Существуют также проблемы, связанные с технологией разработки заводненных объектов, среди которых необходимо выделить неравномерность вытеснения нефти закачиваемой водой из пластов, образование областей обводнения. Отсюда возникает проблема извлечения остаточной нефти из заводненных зон пласта, т.е. увеличения коэффициента нефтеотдачи.

Снижение добычи нефти и газового конденсата повлияло на падение объёмов переработки нефти и производства нефтепродуктов. Снизился уровень загрузки имеющихся производственных мощностей НПЗ с 73,7 \% в 1998 г. до 50-55 \% в 2014 г. [8]. В связи с необходимостью загрузки нефтеперерабатывающих заводов и возобновлением экспорта нефтепродуктов, импорт нефти возрос почти вдвое. Кроме низкой загрузки производственных мощностей нефтеперерабатывающих заводов, деятельность НПЗ становится убыточной из-за высокой стоимости импортного сырья, так как переработка и реализация готовой продукции осуществляется по фиксированным ценам.

Учитывая, что все процессы в нефтегазовой отрасли взаимосвязаны, снижение добычи нефти и газового конденсата также стало причиной недостаточности оборотных финансовых ресурсов отрасли, которые направлялись в первую очередь на закупки импортного сырья. Недостаток финансовых ресурсов стал ограничением возможности обеспечения текущих нужд в цепочке геологоразведка - бурение - добыча. А недофинансирование, в свою очередь, является следствием снижения объема запасов и добычи природного газа. Также к проблемам нефтегазовой отрасли относится высокое значение показателя коэффициента удельных затрат на единицу произведенной продукции.

Деятельность сервисных предприятий НХК «Узбекнефтегаз» ограниченна и требует коренных изменений, а также реформирования. Специфика деятельности сервисных предприятий НХК «Узбекнефтегаз» связана с необходимостью выполнения работ по заказу самого холдинга. 
Кроме того, сервисные предприятия не имеют полномочий для самостоятельной организации закупок сырья и материалов, которые могут потребоваться, если они выигрывают тендер на сервисное обслуживание сторонних компаний.

В развитии внешнеэкономического сотрудничества Узбекистана одной из основных проблем является ограниченность транспортных коммуникаций, в частности отсутствие выхода к морским портам. Кроме того, Узбекистан окружен странами, также не имеющими выхода к морским портам.

К субъективным причинам, оказавшим негативное влияние на развитие нефтегазовой отрасли, относятся [12]:

- неэффективная система управления отраслью, которая не позволяет быстро решать возникающие проблемы;

- недостаточно высокий уровень квалификации кадров, а также низкий уровень менеджмента на всех уровнях управления;

- высокий уровень налоговой нагрузки на отрасль, который не стимулирует ее развитие.

Вывод. По оценкам экспертов, созданная система управления в настоящих условиях демонстрирует свою полную неэффективность, дублирование функций, расточительность в использовании финансовых ресурсов при их большом дефиците даже для неотложных нужд [6].

В долгосрочной перспективе топливная промышленность будет переориентирована на создание высокотехнологичных нефтегазохимических кластеров, что позволит освоить производство продуктов переработки традиционных и альтернативных углеводородов, обладающих высокими качественными характеристиками; альтернативных видов топлива на основе переработки твёрдых бытовых отходов [12]. В химической промышленности в долгосрочной перспективе приоритет будет отдаваться композиционным и углеводородным наноматериалам.

\section{Библиографический список}

1. Чепель С. Альтернативные сценарии развития и активизации новых факторов экономического роста на долгосрочную перспективу: материалы VI форума учёных-экономистов (Т. I) / под общ. ред. А.М. Садыкова. - Ташкент: IFMR, 2019. - C. 3-12.

2. Всемирный банк. Узбекистан: экономика эффективности. 30 апреля 2019 [Электронный pecypc] // Сайт Всемирного Банка. - URL.: http://www.worldbank.org/ru/results/ 2019/04/30/uzbekistan-the-economics-ofefficiency (дата обращения: 07.02.2021).

3. Бобохужаев Ш.И. Проблемы и возможности привлечения инвестиций нефтегазовыми компаниями Узбекистана // Материалы III Междунар. науч.практ. конф., 20 апреля 2019 г. - Пермь: Изд-во Перм. нац. исслед. политехн. унта, 2018. - С. 13-19.

4. Википедия. Страны лидеры по добыче нефти [Электронный ресурс]. URL::

https://ru.wikipedia.org/wiki/\%D0\%A1\%D0\%BF\%D0\%B8\%D1\%81\%D0\%BE\%D0 
\%BA_\%D1\%81\%D1\%82\%D1\%80\%D0\%B0\%D0\%BD_\%D0\%BF\%D0\%BE_\%D0 \%B4\%D0\%BE\%D0\%B1\%D1\%8B\%D1\%87\%D0\%B5_\%D0\%BD\%D0\%B5\%D1\% 84\%D1\%82\%D0\%B8 (дата обращения: 07.02.2021).

5. Бобохужаев Ш.И. Проблемы и пути привлечения инвестиций в газовую промышленность Узбекистана // Материалы IV Междунар. науч.-практ. конф., 28 апреля 2019 г. - Пермь, Изд-во Перм. нац. исслед. политехн. ун-та, 2019. - С. $24-31$.

6. Совершенствование системы управления в нефтегазовом секторе Республики Узбекистан: доклад Центра экономических исследований при содействии проектов Программы развития Организации Объединенных Наций (ПРООН) «Содействие модернизации, ускорению реформ и трансформации» / Т. Шадыбаев, Ж. Мирзамахмудов, Х. Рахматуллаев, Б. Норматов, Е. Шек, Р. Турсунова. - Ташкент, 2019. - С. 14 [Электронный ресурс] // Сайт Центра экономических исследований (ЦЭИ) - URL: http://cer.uz/upload/iblock/1c4/qjdukyuvyzsdraazjzibkirppcshirmjlb\%20pogsebpquq whnlwpzgyb gh\%20yrzffwehpplfmjyfqegz.pdf (дата обращения: 07.02.2021).

7. Нефтяная промышленность Узбекистана. 30 марта 2019 г. [Электронный pecypc] // Сайт Федерального государственного бюджетного учреждения «Центральное диспетчерское управление топливно-энергетического комплекса». - URL.: http://www.cdu.ru/articles/detail.php?ID=309596 (дата обращения: 07.02.2021).

8. Главные показатели развития в итогах 2020 года. Последнее изменение 20.10.2020 [Электронный ресурс] // Официальный сайт НХК «Узбекнефтегаз». URL.:

library/statements/glavnye_pokazateli_razvitija_v_itogah_2018_go da (дата обращения: 07.02.2021).

9. В НХК «Узбекнефтегаз» подведены итоги 2019 года [Электронный ресурс] // Официальный сайт HXK «Узбекнефтегаз». - URL.: http://ung.uznginf.uz/ru/news/v_nhk_ uzbekneftegaz_podvedeny_itogi_2019_goda/ (дата обращения: 07.02.2021).

10. Расулев А.Ф., Тростянский Д.В. Нефтегазовый комплекс Узбекистана: состояние и перспективы // Реформа. - 2002. - № 4. - С. 10-18.

11. Современное состояние и тенденции развития нефтегазового комплекса Туркменистана и других Центральноазиатских стран Ближнего Зарубежья / М.Н. Кнепель [и др.] / ОАО «ВНИИЗарубежгеология». - М., 2015. - С. 236.

12. Коржубаев А.Г., Филимонова И.В. Нефтегазовый комплекс Узбекистана в международной системе энергообеспечения // Минеральные ресурсы России. Экономика и управление. - 2012. № 3 [Электронный ресурс] // Сайт журнала «Маркшейдерия и Недропользование». - URL: http://www.vipstd.ru/ gim/content/view/403/285/ (дата обращения: 07.02.2021).

13. Промышленная продукция. Открытые данные [Электронный ресурс] // Сайт Государственного комитета Республики Узбекистан по статистике. - URL: http://stat.uz/ru/141- otkrytye-dannye/996-promyshlennaya-produktsiya (дата обращения: 07.02.2021). 
14. Промышленность Узбекистана. 2016 // Управление сводноинформационной работы: стат. сб. - Ташкент, 2017. - С. 130.

15. Промышленность Узбекистана. 2019 // Управление сводноинформационной работы: стат. сб. - Ташкент, 2015. - С. 136.

16. Узбекистан в цифрах. 2014 // Управление сводно-информационной работы: стат. сб. - Ташкент, 2015. - С. 114.

17. Узбекистан в цифрах. 2015 // Управление сводно-информационной работы: стат. сб. - Ташкент, 2016. - С. 112.

18. Узбекистан в цифрах. 2016 // Управление сводно-информационной работы: стат. сб. - Ташкент, 2017. - С. 101.

19. Узбекистан в цифрах. 2017 // Управление сводно-информационной работы: стат. сб. - Ташкент, 2018. - С. 120.

20. Узбекистан в цифрах. 2018 // Управление сводно-информационной работы: стат. сб. - Ташкент, 2019. - С. 120. 


\section{АНАЛИЗ “ИНТЕРНЕТ ВЕЩЕЙ" И СФЕРЫ ЕГО ПРИМЕНЕНИЯ}

Зинченко Александр Валерьевич магистрант 5 курса, группа ТМ-01 мп НТУУ «КПИ им. Игоря Сикорского»

Хоменко Александр Николаевич магистрант 5 курса, группа ТМ-01 мп НТУУ «КПИ им. Игоря Сикорского»

\section{Федорова Наталия Владимировна} доктор технических наук, профессор кафедры автоматизации проектирования энергетических процессов и систем НТУУ «КПИ им. Игоря Сикорского»

Internet of Things (IoT) - методология вычислительной сети физических предметов («вещей»), оснащенных встроенными технологиями для взаимодействия друг с другом или с внешней средой, которая рассматривает организацию таких сетей как явление, способное перестроить экономические и общественные процессы таким образом, чтобы исключить из части действий и операций необходимость участия человека. То есть, все физические вещи должны иметь IP-адрес и быть в состоянии общаться с другими вещами, которые будут рассматриваться как часть ІоТ [1].

Концепция сформулирована в 1999 году как осознание перспектив широкого применения средств радиочастотной идентификации для взаимодействия физических предметов между собой и с внешним окружением. Наполнение концепции «Интернета вещей» разнообразным технологическим содержанием и внедрение практических решений для реализации начиная с 2010-х годов считается устойчивой в информационных технологиях, прежде всего, благодаря повсеместному распространению беспроводных сетей, появления облачных вычислений, развития технологий межмашинных взаимодействий, начало активного перехода на IPv6 и освоения программно-конфигурируемых сетей.

Разговоры о бурном развитии технологии «Интернет вещей», о появлении все новых и новых «умных» устройств в последнее время стали привычными. «Интернет вещей» - мир, в котором все виды устройств, от смартфонов и планшетов до холодильников и термостатов, могут свободно обмениваться данными через Интернет и предлагают нам беспрецедентный контроль над нашей средой. Это относится к множеству крошечных, энергосберегающих устройств c Wi-Fi соединением, которые заполняют нашу жизнь. Но это также относится к более широким технологичным стандартам и инфраструктуры, которые позволяют этим устройствам существовать, и взаимодействовать друг с другом, и именно эта инфраструктура позволяет построить себе дом будущего. 
«Интернет вещей» на высоком уровне - это «умный» дом (рис. 1) безусловно, имеет свои преимущества и может сэкономить время и усилия в таких областях, как техническое обслуживание дома и нашего счета за электроэнергию.

На рис. 1.1 показан пример компонентов "умного" дома с использованием "IoT" [2, 3].

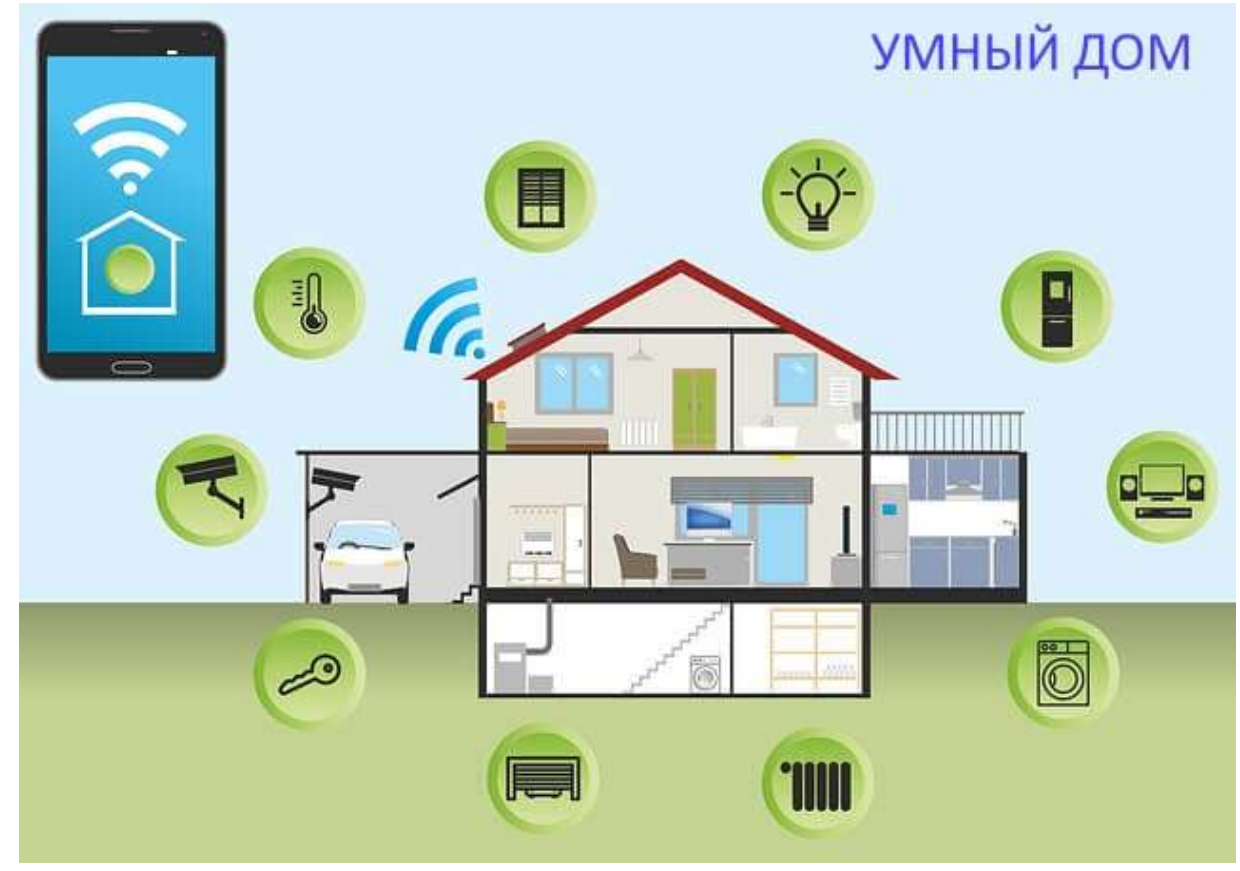

Рис.1. Пример компонентов «умного» дома

«Интернет вещей», как следует из названия, использует Интернет для общения и, в случае качественного «Интернета вещей» гаджет имеет прямое соединение с сервером на сети, а не непосредственно на телефон или компьютер с помощью беспроводной технологии ближнего действия, как Bluetooth. Многие «Интернет вещей» гаджеты используют онлайн-подключения, чтобы позволить вам управлять устройством через веб-браузер или часто через Android или ОС IOS приложение. Эти устройства предназначены для связи друг с другом. Хотя есть множество Интернет вещей, которые имеют более широкие экосистемы, такие как SmartThings и беспроводных протоколов, таких как Z-Wave или ZigBee это означает, что одно «умное» устройство может разговаривать с другим и сделать возможным весь ваш дом работать достаточно быстро.

Для достижения цели с использованием «умного» дома на полках магазинов любимой электроники появляется огромный ассортимент «Интернет вещей». Существуют гаджеты для всего - умные фары, умные жалюзи, умный дом развлечений и аудио, смарт-устройств для приготовления пищи - печей, холодильников і кофеварок, а также интеллектуальных систем, как кондиционер и система безопасности. Очень перспективным является направление телемедицины, когда большие потоки данных с датчиков, подключенных к пациенту, отдаленно будут передаваться по телекоммуникационным каналам i затем обрабатываться в автоматическом режиме [4]. В случае выхода физиологических параметров за допустимые пределы будет осуществлен автоматический вызов скорой помощи. Автоматические транспортные средства, 
будут управлять машиной без постоянного воздействия водителя на органы управления также, наверное, не обойдутся без ІоТ. Уже сейчас появляются первые прототипы автомобилей, которые обмениваются между собой данными и автоматически вызывают аварийные службы в случае дорожно-транспортных происшествий.

International Data Corporation (IDC) определяет IоT как сеть сетей однозначно идентифицируемых подключенных устройств (или «вещей»), которые обмениваются данными на базе IP-соединений без участия человека. IDC подчеркивает, что автономное подключение является ключевым атрибутом в определении, и не учитывает как ІоТ-устройство смартфоны, планшетные компьютеры и ПК. Согласно публикациям компании IDC на IoT-рынке кроме аппаратного и программного обеспечения относятся и IT-услуги, и телекомуслуги. То есть рынок ІоТ находится на стыке IT и телеком-рынка.

Телеком-услуги - это стоимость услуг провайдеров проводной и беспроводной связи для подключения ІоТ-устройств. К IT-услугам относятся консалтинг, услуги по настройке оборудования и программного обеспечения, системная интеграция, услуги поддержки и сопровождения, обучения, а также услуги аутсорсинга информационных систем, включая облачные услуги.

К аппаратному обеспечению в части IoT-рынка IDC относит различного рода подключены IoT-устройства (контроллеры, датчики, RFID-теги и другие проводные или беспроводные ІоТ-устройства). При этом, если устройство, «вещь» или датчик имеет IP-адрес и автономно подключен к сети, в какой-то момент в течение своего жизненного цикла, он подпадает под определение ІоТ. К сегменту аппаратного обеспечения относятся и другие элементы инфраструктуры (серверы, системы хранения данных, сетевое оборудование, включая коммутаторы и маршрутизаторы, а также аппаратные системы обеспечения безопасности). К этому сегменту относится широкий спектр программного обеспечения [5, 6]:

- аналитическое программное обеспечение (ПО), которое использует данные, собранные с помощью подключенных вещей, для перевода их в информацию для принятия управленческих решений;

- прикладное программное обеспечение, которое предоставляет интерфейс, работает с аналитическими приложениями, обеспечивает функции разного рода отраслевой специфики;

- IоT-платформы - специализированные программы, которые интегрируют ряд функций и зачастую включают: мониторинг и управление подключенными устройствами;

- сбор ІоТ-данных, преобразования и управления этими данными, а также разработку ІоТ-приложений;

- часть функциональности ІоТ-платформ может пересекаться с вышеперечисленными категориями ПО;

- программное обеспечение безопасности.

IoT так же набрало популярности в сфере энергетики [6]. Создание интеллектуальных энергетических систем - это модернизация всего комплекса генерации и доставки электроэнергии на основе усовершенствованного 
управления, защиты, оптимизации технологических элементов электроэнергетической системы в их взаимосвязи - от централизованной и рассредоточенной генерации, передачи электроэнергии при высоком напряжении, ее распределения, систем автоматизации, устройств сохранение до конечных потребителей. Интеллектуальные энергетические системы обеспечивают более высокую производительность энергосетей и позволяют повысить надежность и эффективность работы всей системы за счет регулирования потребления, мониторинга и динамического управления двунаправленными потоками энергии в реальном времени. Использование интеллектуальных энерготехнологий обеспечивает лучшую адаптацию к сети пульсирующего динамического характера рассредоточенной генерации и нетрадиционных и возобновляемых источников энергии.

Для снижения операционных издержек и соответствия все более высоким требования регулирования электроэнергетические компании генерируют и передают энергию более эффективно на базе интеллектуальных сетей, опирающихся на «Интернет вещей». Используя интеллектуальные устройства и анализ данных на базе технологий «Интернета вещей» интеллектуальная сеть оптимизирует распределение ресурсов в реальном времени, интегрирует распределенные возобновляемые источники энергии и предсказывает возможность отказа оборудования до того, как он приведет к сбою в работе. Это и есть интеллектуальная энергетика.

\section{Список литературы:}

1. Интернет вещей (Internet of Things, IoT) - https://www.it.ua/ru/knowledgebase/technology-innovation/internet-veschej-internet-of-things-iot

2. Что такое умный дом? - https://unidim.com.ua/blog/umnyy-dom-otoplenie

3. Smart Home / James Chen - www.investopedia.com/terms/s/smart-home.asp

4. Dinsmore T. W. Apache Spark for Big Analytics (Updated for Spark Summit and Release 1.0.1) // The Big Analytics Blog. http://thomaswdinsmore.com/2014/01/02/apache-spark-for-big-analytics/, (01. 02. 2014).

5. IoT Explained - How Does an IoT System Actually Work? https://www.leverege.com/blogpost/iot-explained-how-does-an-iot-system-actuallywork

6. Восемь ключевых технологий «Интернет вещей» окт. 2017 https://www.pwc.ru/ru/publications/Essential-emerging-technologies_IoT_rus.pdf 


\section{ЕЛЕКТРОННИЙ НАВЧАЛЬНО-МЕТОДИЧНИЙ КОМПЛЕКС ДИСЦИПЛІНИ «БАЗИ ДАНИХ»}

Москаленко Артем Олексійович, кандидат технічних наук, завідувач кафедри комп'ютерних наук та інженерії програмного забезпечення, Заклад вищої освіти «Міжнародний науково-технічний університет імені академіка Юрія Бугая»

Івко Сергій Олександрович, кандидат технічних наук, викладач циклової комісії експлуатації військових засобів зв'язку,

Військовий коледж сержантського складу Військового інституту телекомунікацій та інформатизації імені Героїв Крут

\section{Погорілий Віталій Сергійович,} магістрант кафедри комп'ютерних наук та інженерії програмного забезпечення, Заклад вищої освіти «Міжнародний науково-технічний університет імені академіка Юрія Бугая»

Впровадження у навчальний процес досягнень комп'ютерно-орієнтованих технологій навчання створить передумови для $[1,2]$ : поглиблення змісту освіти, інтенсифікації процесу навчання, розвитку особистості, стимулюванням пізнавальної активності курсантів, підготовки спеціалістів, підготовки фахівців, здатних працювати в умовах інформаційного суспільства та ефективно використовувати знання на практиці.

Електронні навчальні видання поділяються на наступні різновиди: електронні навчально-методичні комплекси; електронні підручники; електронні навчальні посібники; електронні конспекти. Електронні навчально-методичні комплекси дисципліни (ЕНМКД) - інформаційно-дидактичні ресурси дисципліни подані у формі електронного видання.

За результатами аналізу останніх досліджень, можна зробити висновок, що питання розробки та застосування електронних навчально-методичних комплексів, як інтерактивної технології комп'ютерно-орієнтованого навчання 3 дисципліни «Бази даних» майбутніх фахівців за напрямом підготовки 121 «Інженерія програмного забезпечення», досліджені недостатньо. Саме тому впровадження даної технології у навчальний процес вищих навчальних закладів потребує окремих досліджень.

Отже, метою даного дослідження є розробка інтерфейсу електронного навчально-методичного комплексу з навчальної дисципліни «Бази даних» для вищих навчальних закладів. 
У відповідності до робочої програми навчальної дисципліни «Бази даних» проведено обгрунтування раціональної структури та інтерфейсу електронного навчально-методичного комплексу з дисципліни «Бази даних» (рис. 1).

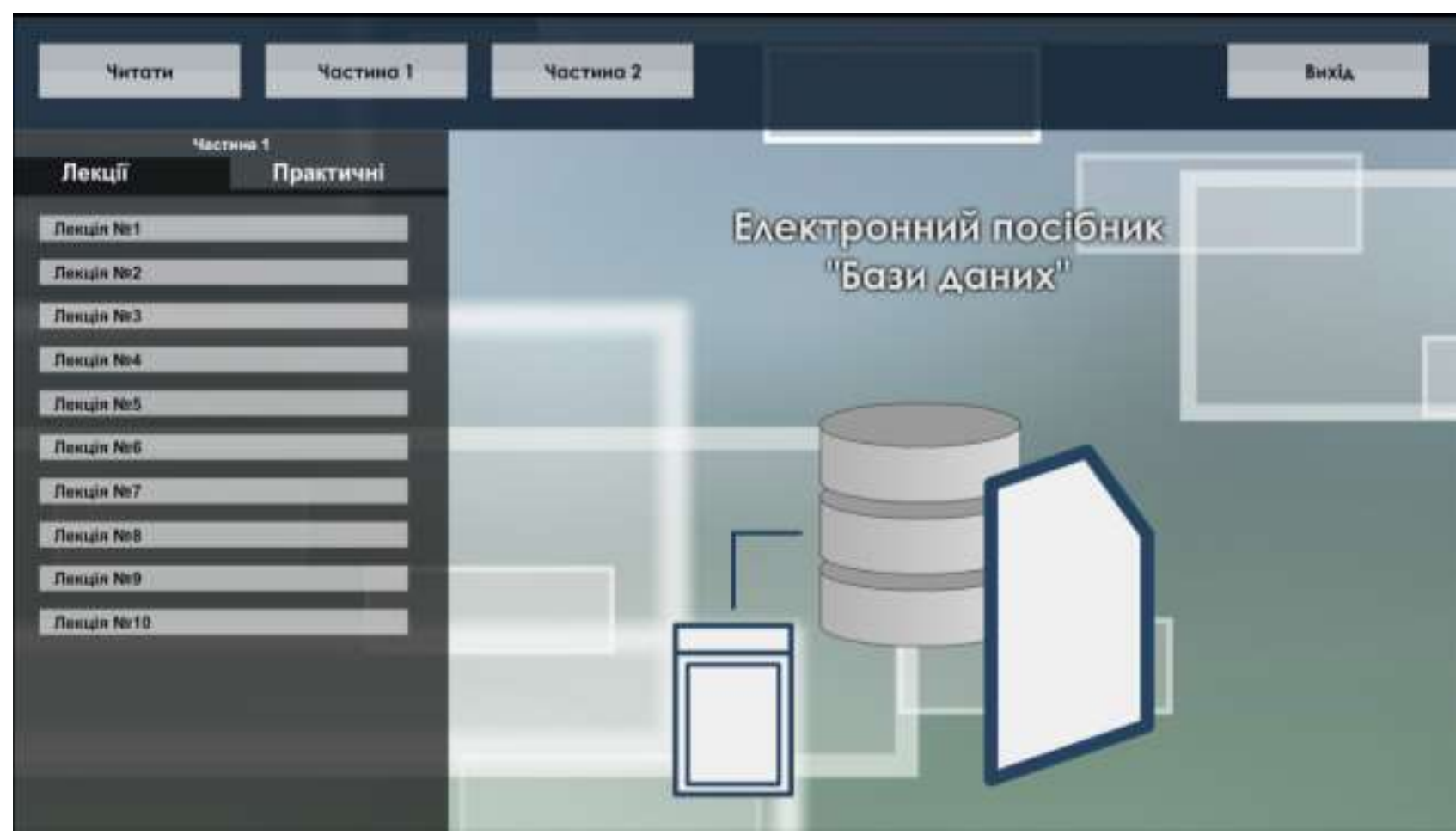

Рис. 1. Інтерфейс електронного навчально-методичного комплексу дисципліни «Бази даних»

Інтерфейс головного вікна електронного навчально-методичного комплексу з дисципліни «Бази даних» містить два елементи управління:

- кнопка «Вихід»: призначена для виходу із системи;

- кнопка «Читати»: призначена для подальшої роботи 3 навчальнометодичним комплексом.

При натисканні на кнопку читати у діалоговому вікні з'являються (рис. 1): кнопка «Частина 1» - що відповідає першому семестру вивчення дисципліни; кнопка «Частина 2»- що відповідає першому семестру вивчення дисципліни.

При виборі необхідної часини комплексу з'являються дві вкладки: лекції та практичні.

У відповідності до робочої програми навчальної дисципліни «Бази даних» для студентів денної та заочної форм навчання за спеціальністю 121 «Інженерія програмного забезпечення〉 [4], частина перша комплексу містить навчальнометодичні матеріали 10 лекцій, 10 практичних робіт, два модульних тести, один підсумковий тест та методичні рекомендації до курсової роботи.

При виборі відповідного лекційного заняття, наприклад №10, відкривається вікно інстальованого PDF-редактора 3 відповідними навчально-методичними матеріалами (рис. 2). 


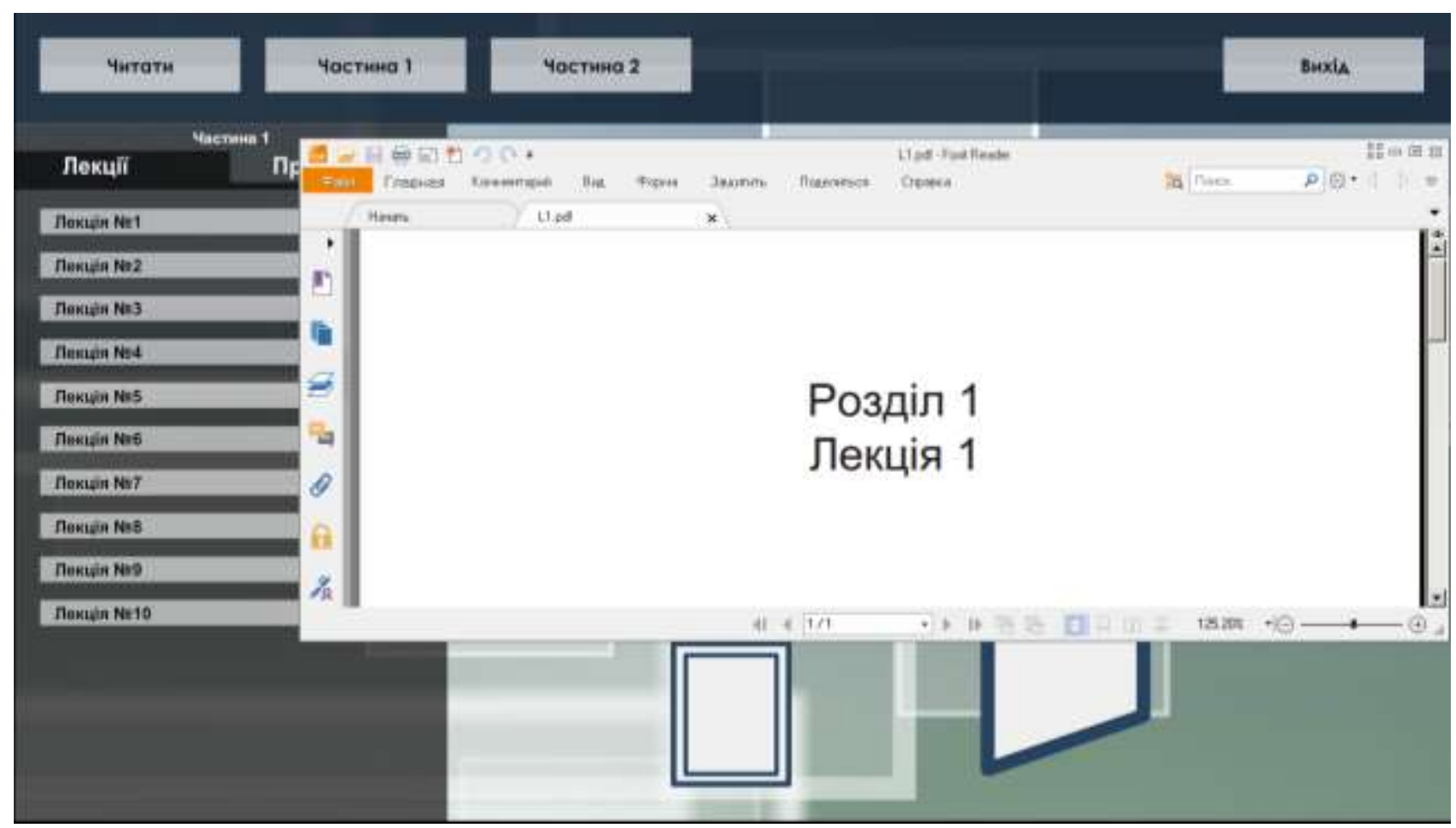

Рис. 2. Відображення матеріалу лекцій в електронному навчально-методичному комплексі дисципліни «Бази даних»

При проведенні модульного та підсумкового тестування можливо два варіанти. Варіант №1 - проведення модульного та підсумкового тестування 3 використанням програмного комплексу MyTest та розроблених тестів. У цьому випадку, викладачем завчасно розроблюється набір тестових завдань 3 дисципліни та реалізовується у середовищі MyTestEditor, що входить до складу програмного комплексу MyTest. Студент обирає необхідний тест, із каталогу, що вказаний викладачем або відомий завчасно, та реєструється у системі.

3 цією метою, студент вказує власне прізвище та ім'я, а також навчальну групу. Після цього виконує тестові завдання, за результатами яких відбувається оцінювання в автоматичному режимі. Результати заносяться до відповідного протоколу та відображуються у MyTestServer (рис. 3).

Варіант №2 - проведення модульного та підсумкового тестування 3 використанням pdf-формату та розроблених тестів. У цьому випадку, модульні та підсумкові тести розроблені та збережені у pdf-документі. Студент обирає необхідний тест та складає його. При цьому допускається друк тестових завдань на мережевому принтері.

Розроблено електронний навчально-методичний комплекс 3 дисципліни «Бази даних» засобами ActionScript. До складу комплексу входять: навчальне програмне забезпечення, теоретичні матеріали, практичні матеріали, методичні матеріали, довідкові матеріали, наочні матеріали та бібліографічні матеріали. 


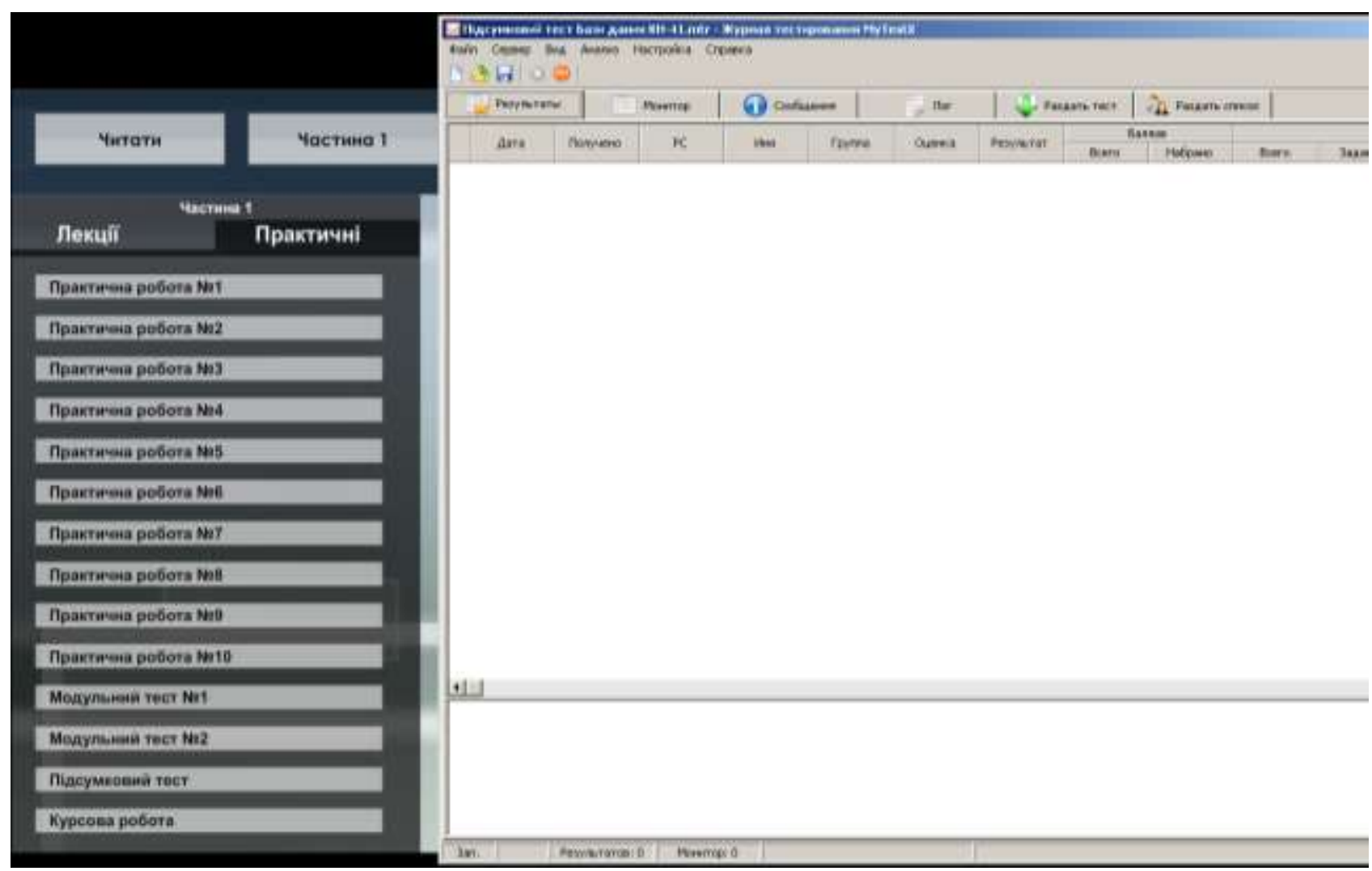

Рис. 3. Відображення результатів тестування в MyTestServer

Матеріали лекції, практичних занять, тести для проведення модульного i підсумкового тестування можливо доопрацьовувати та змінювати. Для цього необхідно провести лише заміну відповідного файлу на новий.

Таким чином, використання розробленого комплексу сприятиме підвищення інтересу до обраної професії, а також формуванню у студентів міцних знань 3 дисципліни, що є запорукою успішного працевлаштування у майбутньому. Перспективами досліджень є: перевірка ефективності комплексу в умовах навчального процесу; розробка методичних рекомендацій для викладачів 3 питань впровадження і використання електронного навчально-методичного комплексу 3 дисципліни «Бази даних» у навчальному процесі.

\section{Список літератури:}

1. Пометун О. І. Інтерактивні технології навчання: Наук.-метод. посібн. / О. І. Пометун, Л. В. Пироженко. - К.: Видавництво А.С.К., 2004. - 192 с.

2. Триус Ю. В. Комп'ютерно-орієнтовані методичні системи навчання: Монографія/ Ю. В. Триус. - Черкаси: Брама - Україна, 2005. - 400 с.

3. Колин М. ActionScript 3.0 для Flash. Подробное руководство. / М. Колин. СПб.: Питер, 2009. - 992 с.

4. Бази даних: робоча програма навчальної дисципліни для студентів напряму підготовки 121 «Інженерія програмного забезпечення» денної та заочної форм навчання / Міністерство освіти і науки України, Полтавський інститут бізнесу Міжнародного науково-технічного університету імені академіка Юрія Бугая; Москаленко А.О. - Полтава: [ПІБ МНТУ], 2019. - 20 с. 


\title{
ЕКОЛОГІЧНА ОЦІККА ПРОЦЕСУ СТИМУЛЯЦІЇ ГАЗОПЕРСПЕКТИВНОГО РОДОВИЩА
}

\author{
Немченко Олена Вікторівна \\ магістр, Державна екологічна академія \\ післядипломної освіти та управління, м. Київ, Україна
}

Так сталося, що природний газ являється основним енергоносієм у паливноенергетичному комплексі України. Хоча природний газ при використанні в промисловості та побуті має менш значний вплив на навколишнє природне середовище, ніж інші види енергоносіїв, таких як торф, дрова, нафта, вугілля, але проведення робіт з видобутку газу — це ризик для довкілля. Крім того, проведення робіт з геологічного вивчення, буріння свердловини, проведення операції з капітального ремонту існуючої газової свердловини, стимуляція (інтенсифікація видобутку вуглеводнів із проблемних нафтових, газових i газоконденсатних свердловин), здійснення гідророзривів тощо в районах зі складним природним ландшафтом та розвинутими наземними та підземними водними системами, також $є$ дуже небезпечними з екологічної та антропогенної точки зору.

Екологічне навантаження на природне середовище при цьому має декілька аспектів, це - порушення земної поверхні, забруднення грунту, повітряного і водного середовища (рис.1).

\section{$\underline{\text { Характер впливу }} \quad \underline{\text { Об'єкт впливу }}$}

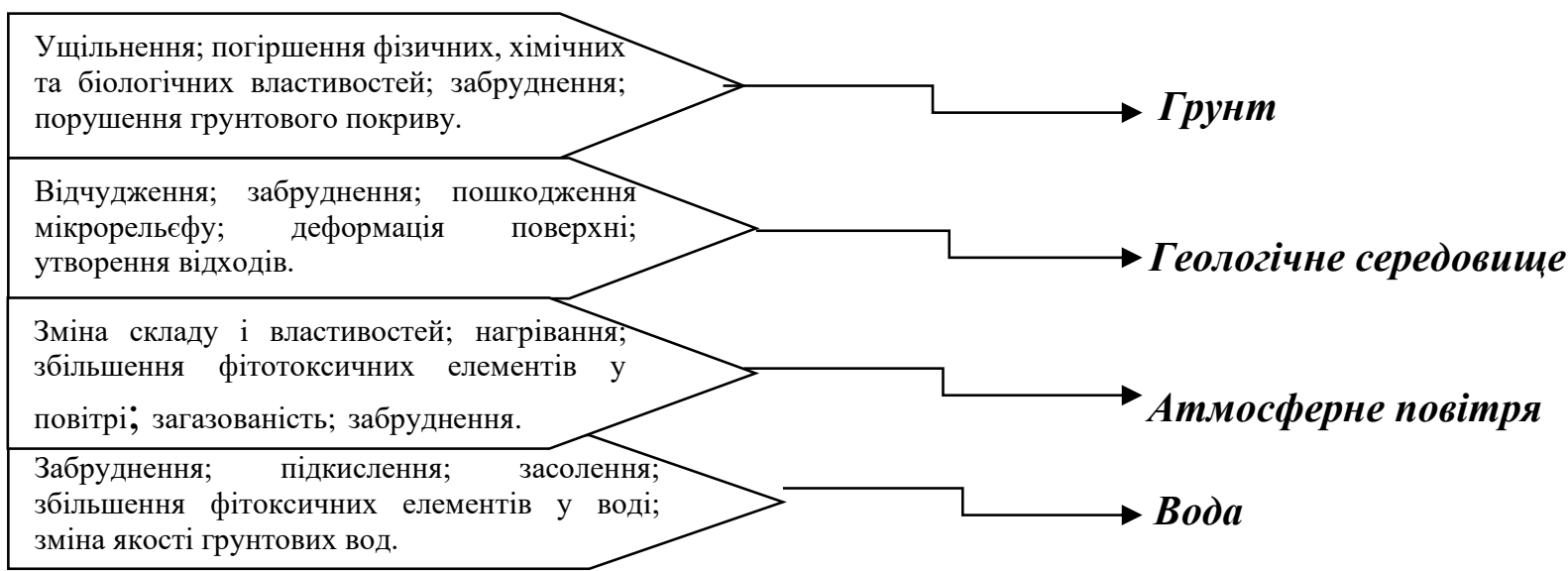

Рис.1 Екологічні аспекти проведення робіт з видобутку газу

Що ж являс собою метод стимуляції припливів газу свердловини?

Стимуляція припливу газу в свердловині - це один із методів інтенсифікації роботи свердловин. Метод полягає у створенні високопровідникової тріщини в цільному пласті для забезпечення припливу флюїду, який видобувають (газ, вода, конденсат, нафта або їх суміш).

У вітчизняній нафтогазовій галузі стимулювання свердловин почали застосовувати з 1952 р. Загальна кількість стимулювань у СРСР в період з 1958- 
1962 рр. перевищувала 1500 операцій на рік, а в 1959 р. досягла 3000 операцій, які мали високі техніко-економічні показники.

В Україні, вперше стимулювання свердловини було проведено на Бориславському родовищі. Відродження вітчизняного стимулювання почалось в кінці 80-х років у зв'язку з суттєвою зміною структури запасів нафти і газу. На сьогодні, в Україні проведено десятки тисяч стимулювань свердловин. 31996 p. і до сьогодні тільки силами ПАТ «Укрнафта» проведено близько 350 операцій. Успішним прикладом організації виконання робіт в Україні $\epsilon$ досвід на свердловині R-103 Руденківського родовища в Полтавській області, який за своїми параметрами на сьогоднішній день $є$ одним з найбільших стимулювань суші на території Європи.

Технологія здійснення стимуляції включає закачування в свердловину за допомогою насосних агрегатів рідини розриву (гель, у деяких випадках вода) за тиску, що вищий тиску розриву пласта. Для підтримки тріщини у відкритому стані в колекторах використовують розклинювальний агент - пропант.

В процесі виконання стимуляції використовуються рідини, хімічні домішки, а також пропанти. До складу рідин для стимуляції входять: хлорид калію, метанол, поверхнево-активні речовини, азотовмісні сполуки, карбонова кислота, нафтопродукти, сульфати, натрієва сіль тіосульфокислоти, фосфати.

Метод стимуляції припливу газу здійснюється в функціонуючій газовій свердловині

Контроль за станом навколишнього природного середовища, а саме - станом грунту, атмосферного повітря, поверхневих та грунтових вод необхідно проводити до та після процесу стимуляції, а також 3 метою подальшого порівняльного аналізу відбирати проби в місцях, розташованих в межах санітарно-захісної зони (С33), території житлової забудови, біля водойм, колодязів та інш.

Зразки грунту відбираються на промислових майданчиках відповідно до вимог ГОСТу $[1,2]$ спеціальним буром на глибині 0-20 см, гніздовим методом, що характеризує усереднений склад об'єкта контролю в даному місці, будучи різновидом об'єднаної проби.

Проводиться аналіз якості грунтів за наступними показниками: водневий показник $\mathrm{pH}$, сульфати, хлориди, кальцій, магній, залізо, нафтопродукти.

Під час проведення моніторингу атмосферного повітря в обов'язковому порядку визначається наявність в атмосферному повітрі загальнопоширених забруднюючих речовин зазначених у списку А Постанови КМУ [5], а також відповідно до Переліку найбільш поширених і небезпечних забруднюючих речовин, викиди яких в атмосферне повітря підлягають регулюванню[6].

При моніторингу атмосферного повітря забруднюючи речовини, які підлягають обов'язковому контролю наступні: оксид вуглецю, оксид азоту, діоксид азоту, діоксид сірки, метан, пил (не диференційований за складом), сума вуглеводнів[3].

Технологія стимуляції припливу газу свердловини не передбачає прямого контакту технологічних рідин з поверхневими та підземними водами, що можуть бути використані як джерела господарсько-питного водопостачання. 
Можливість впливу на водні джерела за рахунок відпрацьованих технологічних рідин, поривів трубопроводів, негерметичності обсадної колони виключається (або зводиться до мінімуму) за рахунок застосування відповідних технічних та природоохоронних рішень.

Виходячи із аналізу складу рідин для стимуляції, керуючись Державними санітарними нормами і правилами [4], дослідження якості проб води необхідно проводити за наступними показниками: температура, $\mathrm{pH}$, жорсткість, запах, колір, прозорість, сполуки азоту (нітрати, нітрити, амоній), нафтопродукти, сухий залишок, мінералізація, залізо загальне, хлориди, фосфати, сульфати, ХСК, АПАР, алюміній, гідрокарбонати, кальцій, магній, натрій + калій, токсичність, E-coli.

От же до проекту технології стимуляції газової свердловини необхідно визначити джерела впливу на навколишнє природне середовище і встановити ступінь цього впливу.

Проведення моніторингових досліджень дають змогу встановити негативну дію на поверхневий шар грунту, підземні та поверхневі горизонти 3 прісними водами, геологічне, повітряне та соціальне середовища.

\section{Список літератури}

1.ГОСТ 17.4.3.01 - 83. Охрана природы. Почвы. Общие требования к отбору проб.

2.ГОСТ 17.4.4.02-84. Охрана природы. Почвы. Методы подбора и подготовки проб для химичского, бактериологического анализа.

3.Постанова Кабінету Міністрів України від 29.11.2001р. № 1598 «Про затвердження Переліку найбільш поширених і небезпечних забруднюючих речовин, викиди яких в атмосферне повітря підлягають регулюванню».

4.Державні санітарні правила і норми «Гігієнічні вимоги до води питної, призначеної для вживання людиною», ДСанПіН 2.2.4-171-10.

5.Список А Постанови КМУ від 09.03.1999 р. № 343 «Про затвердження Порядку організації та проведення моніторингу в галузі охорони атмосферного повітря».

6. Постанова Кабінету Міністрів України від 29.11.2001 р. № 1598 «Про затвердження переліку найбільш поширених i небезпечних забруднюючих речовин, викиди яких в атмосферне повітря підлягають регулюванню». 


\title{
ЯК ПІДВИЩИТИ ЕФЕКТИВНІСТЬ КОНТРОЛЮ І НАГЛЯДУ У СФЕРІ ОХОРОНИ АТМОСФЕРНОГО ПОВІТРЯ
}

\author{
Сікуліна Анна Юріївна \\ магістр, Державна екологічна академія \\ післядипломної освіти та управління, м. Київ, Україна \\ Сидоренко Олена Миколаївна \\ магістр, Державна екологічна академія \\ післядипломної освіти та управління, м. Київ, Україна
}

Атмосферне повітря є життєво важливим компонентом навколишнього природного середовища. Це надійний захист від шкідливих космічних випромінювань, воно визначає клімат конкретної місцевості і планети в цілому, а також має вирішальний вплив на здоров'я людини, іiі працездатність, на життєдіяльність рослинного і тваринного світу.

На жаль, для України серйозною проблемою є відсутність дієвого контролю за шкідливими викидами в атмосферне повітря, яка обумовлена різними причинами.

\section{Чому так сталося?}

Починаючи з 2007 року, у системі екологічного контролю, в тому числі контролю охорони атмосферного повітря відбулися зміни, що зробили цю систему практично недієвою. Державні інспектори відтепер позбавлені права виїжджати на місце порушення відразу ж, як тільки їм стало про них відомо. Забороняється проводити заплановані заходи контролю без попередження. Функція нагляду прокуратури за дотримання природоохоронного законодавства скасована.

Результат вищезазначених дій - поганий та неефективний контроль. Він не дозволяє якісно реєструвати порушення, виявлення винного, визначати суми збитків, знаходити інші докази тощо. Як наслідок, незважаючи на протиправні дії, заходи контролю не виявляють всіх даних, які необхідні для правильного визначення злочинної діяльності або встановлення особи, яка вчинила таку діяльність. Крім того, призупинення перевірок у попередні роки також негативно вплинуло на кількість виявлених порушень, знаходженні винуватця та компенсацію екологічних збитків.

Штрафи за адміністративні правопорушення в галузі охорони навколишнього середовища дуже низькі. 31996 року неоподаткований мінімум доходів громадян, становить 17 грн. Він $є$ основою для розрахунку штрафів відповідно до кримінальних та адміністративних норм. На противагу цьому, мінімальна заробітна плата в 1996 році становила 15 гривень, а в 2017 році - 3200 гривень. Як результат, покарання не спонукає правопорушників та потенційних правопорушників змінити свою поведінку. Крім того, така ситуація іноді підбадьорює правопорушника, оскільки вигода (гроші, що заощаджуються за 
рахунок встановлення чистого фільтра) у багато разів перевищує ризик (сплата штрафу відповідно до закону). В результаті цього, порушники будуть і надалі вчиняти такі злочини неодноразово після обвинувачення.

До 2014 року Державна екологічна інспекція мала право обмежувати та тимчасово призупиняти діяльність компаній, які порушують екологічні вимоги. У процесі дерегуляції це право контролюючого органу було скасовано. Тепер лише суди можуть заборонити або призупинити шкідливу підприємницьку діяльність. Ця ситуація дуже небезпечна, оскільки за час очікування на отримання такого рішення у атмосферне повітря виділяється багата кількість токсичних речовин.

Недієвий інститут відповідальності дає можливість безвідповідальному бізнесу безкоштовно чи дешево використовувати природні ресурси, безкарно скидати надмірні скиди, викиди $i$ відходи виробництва, економити, не встановлюючи сучасне очисне обладнання.

\section{Що потрібно змінити?}

Для подолання такої вкрай небезпечної ситуації треба вдосконалити законодавчу базу з охорони довкілля, а саме: доповнити ст. 11 і 12 ЗУ «Про основні засади державного нагляду (контролю) у сфері господарської діяльності» [2] нормами про обов'язок суб'єкта господарювання забезпечити присутність керівника або уповноваженої особи за місием реєстрації, або за місием здійснення господарської діяльності протягом 24 годин з моменту початку перевірки. А ст.188-5 Кодексу України про адміністративні правопорушення [1] доповнити нормою накладення штрафу на посадових осіб від однієї тисячі до двох тисяч неоподатковуваних мінімумів доходів громадян.

Важливим, на нашу думку, є також правильна оцінка ефективності роботи екологічної інспекції. Вважаємо, що для посилення дієвості екологічного контролю доцільно визначати ефективність роботи поліпшенням показників якості компонентів довкілля конкретного регіону.

Очікуваним наслідком від реалізації пропозиції є:

Нівелювання можливості суб'єктів господарювання затягувати час перед перевіркою, або взагалі не допускати до здійснення заходів державного нагляду (контролю), що в свою чергу повинно забезпечити реалізацію одного із основних принципів права - невідворотність покарання за порушення вимог чинного законодавства.

Разом 3 тим, суттєво підвищити ефективність контролю за викидами в атмосферне повітря можна змінами, зокрема з технічним удосконаленням самої системи контролю. Для цього у Законі України «Про охорону атмосферного повітря» [3] необхідно зобов'язати підприємства, установи, організації та громадян - суб'єктів підприємницької діяльності, що здійснюють викиди забруднюючих речовин в атмосферне повітря та діяльність яких пов'язана 3 впливом фізичних та біологічних факторів на його стан, - встановлювати автоматизовані прилади контролю на стаціонарних джерелах викидів, а також оприлюднювати інформацію про викиди забруднюючих речовин в атмосферне повітря〉. 
Такі зміни дали б можливість оперативно виявляти джерела забруднення атмосферного повітря і зосередити зусилля органів Держекоінспекції на виконанні функцій нагляду за додержанням вимог законодавства, перенести контрольні функції за впливом на стан атмосферного повітря стаціонарних джерел викидів на рівень відомчого і виробничого.

Отже, удосконалення системи контролю і нагляду за викидами в атмосферне повітря, застосування найкращих практик природоохоронної діяльності i законодавства ЄС, забезпечення невідворотності покарання та посилення відповідальності за порушення законодавства у сфері охорони атмосферного повітря одночасно з впровадженням економічних стимулів до екологічно безпечного господарювання здатне поліпшити стан атмосферного повітря в Україні.

\section{Список літератури}

1. Кодекс України про адміністративні правопорушення. Введений в дію Постановою Верховної Ради Української РСР від 07.12.1984 № 8074-10; стаття $185-5$.

2. Про основні засади державного нагляду (контролю) у сфері господарської діяльності: Закон України від 05.04.2007 № 877-V; статті 11, 12.

3. Про охорону атмосферного повітря: Закон України від 16.10.1992 № 2708XII. 
The authors of the XI International Scientific and Practical Conference «Topical issues of modern science and education» were representatives of the following educational institutions:

Bila Tserkva National Agrarian University; Uman National University of Horticulture; Kharkiv National Agrarian University named after V.V. Dokuchayev; A.N. Beketov Kharkov National University of Urban Economy; Lviv Polytechnic National University; National University of Life and Environmental Sciences of Ukraine; Old Polish University in Kielce; Lviv National Agrarian University; Sumy National Agrarian University; Carpathian University named after Augustin Voloshin; Institute of Industrial Economics, National Academy of Sciences of Ukraine; Ivan Franko National University of Lviv; National Transport University; National Technical University of Ukraine "Igor Sikorsky Kyiv Polytechnic Institute"; Lviv National Academy of Arts; National Aviation University; Borys Hrinchenko Kyiv University; Ivano-Frankivs Branch Of Open International University Of Human Development "Ukraine"; Dnipropetrovsk Medical Academy des Gesundheitsministeriums; Bogomolets national medical university; Belarusian State Medical University; Bukovinian State Medical University; National Medical Academy of Post-Graduate Education Named After P.L. Shupik; Kharkiv National Medical University; Kharkiv National University of Pharmacy; South Ukrainian National Pedagogical; University named after K. D. Ushynsky; Lutsk Pedagogical College; Ternopil Volodymyr Hnatiuk National Pedagogical University; Southern Federal University; Pavel Tychyna Uman State Pedagogical University; Dnipro Academy Of Continuous Education; Hryhoriy Skovoroda University in Pereyaslav; Georgian technical university; Ivan Franko National University of Lviv; Rivne State Humanitarian University; Karagandy State University; Ukrainian Medical Stomatological Academy; Kryvyi Rih State Pedagogical University; National Academy of Statistics; National University of Ukraine on Physical Education and Sport; Vinnytsia National Pirogov Medical University; Odessa State University of Internal Affairs; Bohdan Khmelnytsjyi National University of Cherkasy; Lviv State University of Physical Culture; Kharkiv National Automobile and Highway University; Taras Shevchenko National University of Kyiv; «Zaporizhzhia Polytechnic» National University; Municipal Institution of Higher Education «Khortytsia National Educational Rehabilitation Academy»; Izmail State Humanitarian University; Chernihiv National Pedagogical University named after Taras Shevchenko; Peoples' Friendship University of Russia; Igor Sikorsky Kyiv Polytechnic Institute; Academician Yuriy Bugay International Scientific and Technical University; Ivan Kozhedub Kharkiv National Air Force University; Military Institute of Telecommunications and Information Technologies named after Heroes of Kruty; State Ecological Academy of Postgraduate Education and Management. 


\title{
TOPICAL ISSUES OF MODERN SCIENCE AND EDUCATION
}

\author{
Scientific publications
}

Materials of the XI - the International Science Conference «Topical issues of modern science and education», Tallinn, Estonia. 248 p. (March 11 - 13, 2021)

UDC 01.1

ISBN - 978-1-63732-132-4 DOI - 10.46299/ISG.2021.I.XI

Text Copyright (C) 2021 by the International Science Group(isg-konf.com).

Illustrations (C) 2021 by the International Science Group.

Cover design: International Science Group(isg-konf.com) ${ }^{\oplus}$

Cover art: International Science Group(isg-konf.com) ${ }^{\odot}$

All rights reserved. Printed in the United States of America.

No part of this publication may be reproduced, distributed, or transmitted, in any form or by any means, or stored in a data base or retrieval system, without the prior written permission of the publisher.

The content and reliability of the articles are the responsibility of the authors. When using and borrowing materials reference to the publication is required. Collection of scientific articles published is the scientific and practical publication, which contains scientific articles of students, graduate students, Candidates and Doctors of Sciences, research workers and practitioners from Europe, Ukraine, Russia and from neighboring countries and beyond. The articles contain the study, reflecting the processes and changes in the structure of modern science. The collection of scientific articles is for students, postgraduate students, doctoral candidates, teachers, researchers, practitioners and people interested in the trends of modern science development.

The recommended citation for this publication is: Hrynevych N., Zharchynska V. Polymerase chain reaction and its application in aquaculture // Topical issues of modern science and education. Abstracts of XI International Scientific and Practical Conference. Tallinn, Estonia 2021. Pp. 10-11.

URL: https://isg-konf.com. 